\title{
Modelos de FundamentaÇão Filosófica Do Direito Privado e Seus Limites: \\ Contribuição À Crítica do Direito Privado
}

Tese apresentada à Banca Examinadora do Programa de Pós-Graduação em Direito, da Faculdade de Direito da Universidade de São Paulo, como exigência parcial para obtenção do título de Doutor em Direito, na área de concentração de Filosofia e Teoria Geral do Direito, sob orientação do Professor Titular Ronaldo Porto Macedo Júnior.

Universidade de São PaUlo

FACULDADE DE DiREITO

SÃo PaUlo - SP

2015 


\section{BANCA EXAMINADORA:}

Prof.(a)

Prof.(a)

Prof.(a)

Prof.(a)

Prof.(a) 


\author{
Catalogação da Publicação \\ Serviço de Biblioteca e Documentação \\ Faculdade de Direito da Universidade de São Paulo
}

\begin{abstract}
Muñoz, Alberto Alonso
Modelos de Fundamentação Filosófica do Direito Privado e seus Limites: Contribuição à Crítica do Direito Privado / Alberto Alonso Muñoz; orientador Ronaldo Porto Macedo Júnior -- São Paulo, 2015.

172

Tese (Doutorado - Programa de Pós-Graduação em Filosofia do Direito e Teoria Geral do Direito) - Faculdade de Direito, Universidade de São Paulo, 2015.

1. Filosofia do Direito. 2. Direito Privado. 3. Teoria Crítica do Direito. 4. Direito e Teoria Literária. 5. Direito e Marxismo. I. Macedo Júnior, Ronaldo Porto, orient. II. Título.
\end{abstract}




\section{RESUMO}

Alberto Alonso Muñoz. Modelos de Fundamentação Filosófica do Direito Privado e seus Limites: Contribuição à Crítica do Direito Privado. 2015. 172 p. Doutorado - Faculdade de Direito, Universidade de São Paulo, 2015.

Neste trabalho, a partir da exposição das quatro principais teorias que pretendem fornecer os "fundamentos filosóficos" do Direito Privado (e que se revelarão construções ideológicas a serviço de sua legitimação), pretende-se mostrar que esse "ramo" do direito compõe na verdade um conjunto de narrativas correspondendo ao menos a quatro figuras do indivíduo abstrato da ideologia da moderna sociedade burguesa que elas elegem como centrais. Tais imagens-narrativas, examinadas com algumas ferramentas da teoria literária, se caracterizam e ganham efetividade antes por suas lacunas, silêncios e omissões do que por seus conteúdos positivos (mecanismo pelo qual opera a abstração das condições sociais concretas). Elas organizam o conteúdo de uma representação social que orienta ideologicamente a prática do Direito Privado, abrangendo a elaboração do texto normativo, sua interpretação dogmática e a decisão judicial que afirma e se supõe aplicadora da norma. Além disso, do ponto de vista formal, o direito apresenta-se como norma, que é vista como átomo fundamental do "sistema jurídico" (concepção clássica que constitui ainda hoje o núcleo mínimo das diversas teorias da tradição positivista jurídica). A crítica avançará para demonstrar que o direito não é um sistema de normas, mas sim que a norma (e o discurso da sua "aplicação") é antes o modo socialmente necessário pelo qual o direito, como prática social de poder e mascaramento da violência, tem de aparecer. Na norma redescobriremos, como lembra Isaac Balbus, por fim, reproduzida homologicamente, a mesma estrutura do fetichismo da formamercadoria decomposta por Marx no livro I de O Capital. É, portanto, na aparência fetichista do direito, apresentando-se na fantasmagoria do sistema de normas (na produção legislativa, na dogmática e na decisão), manifestando-se como entidade metafísica autônoma e independente para os que a "elaboram", a "interpretam", a "aplicam" ou lhe seriam "seus destinatários", que descobriremos por fim o mecanismo que assegura a eficácia ideológica do conteúdo do direito, condição de possibilidade mesma da ocultação de sua essência de práxis de poder e de violência, dirigida por aquelas imagensnarrativas que o guiam.

Palavras-chaves: Direito Privado. Normativismo. Positivismo. Narrativas jurídicas. Representações sociais no direito. Imaginação jurídica. Direito e Teoria Literária. Indi- 
víduo abstrato. Norma jurídica. Sistema jurídico. Comunidade interpretativa. Direito e interpretação. Forma-mercadoria. Marxismo. Teoria Crítica do Direito. Filosofia do Direito. Teoria Geral do Direito. 


\section{RESUMEN}

Alberto Alonso Muñoz. Modelos de fundamentación filosófica del Derecho Privado y sus límites: Contribución a la Crítica de Derecho Privado. 2015. 172 p. Doctorado - Fa cultad de Derecho de la Universidad de São Paulo, en 2015.

En este trabajo, utilizando como estrategia metodológica la exposición de una crítica ideológica de cuatro teorías que pretenden encontrar los "fundamentos filosóficos del Derecho Privado", se pretende demostrar que esta "rama" del derecho se sustenta en realidad sobre un conjunto de narrativas correspondiente a por lo menos cuatro figuras del individuo abstracto de la ideología burguesa. Tales imágenes-narrativas, examinadas con las herramientas de la teoría literaria, que se caracterizan y se hacen efectivas antes por sus lagunas, silencios y omisiones que por su contenido positivo (es decir, a través de la abstracción del concreto histórico-social), organizan una representación social que orienta ideológicamente la práctica del Derecho Privado, incluida la preparación de un texto legislativo, su interpretación dogmática y la decisión judicial que se supone aplicadora de la norma. La norma ya no es más el átomo fundamental del derecho entendido como un sistema (diseño clásico que es el núcleo mínimo de las diversas teorías de la tradición positivista jurídica), pero el modo necesario de la aparición social de derecho como práctica social de poder y enmascaramiento de la violencia. En la norma finalmente redescubrimos la misma estructura homológica del fetichismo de la formamercancía descompuesta por Marx en el libro I de El Capital. Es la apariencia fetichista del derecho, que se presenta como conjunto de normas (en la producción legislativa, en la interpretación dogmática y en la decisión), manifestándose como una entidad metafísica autónoma e independiente para los que la "elaboran", "interpretan", "aplican", o serían "sus destinatarios", que finalmente se descubre el fundamento de la eficacia ideológica del derecho, condición de posibilidad misma del ocultamiento de su esencia como praxis de poder y violencia.

Palabras clave: Derecho Privado. Normativismo. Positivismo. Narrativas jurídicas. Representaciones sociales del derecho. Imaginación jurídica. Derecho y Teoría Literária. -Individuo abstracto. Norma jurídica. Sistema jurídico. Comunidad interpretativa. Derecho e interpretación. Forma-mercancía. Marxismo. Teoría Crítica del Derecho. Filosofía del Derecho. Teoría General del Derecho. 


\section{RESUME}

Alberto Alonso Muñoz. Modèles de fondementation philosophique du Droit Privé et ses limites : Contribution à la critique du Droit Privé. 2015. 172 p. Doctorat - Faculté de Droit, Université de São Paulo, 2015.

Dans ce travail, en employant comme stratégie méthodologique l'exposition d'une critique ideologique de quatre théories qui aiment trouver les « fondements philosophiques de Droit Privé », nous tenons à démontrer que cette « branche » du droit est soutenue en fait par un ensemble de récits correspondant à au moins quatre figures de l'individu abstrait de l'idéologie bourgeoise. Ces images-récits, examinés avec les outils de la théorie littéraire, sont caractérisés et prendent effet plutôt par ses lacunes, ses silences et ses omissions que par son contenu positif (c'est-à-dire, par l'abstraction $\mathrm{du}$ concret socio-historique), composant une représentation sociale qui guide idéologiquement la pratique du Droit Privé, y compris la préparation du texte législatif, son interprétation dogmatique et la décision judiciaire qui s'affirme comme application de la norme. La norme n'est plus l'atome fondamental du droit, conçu comme un système (conception classique qui est le noyau minimum des diverses théories de la tradition du positivisme juridique), mais le mode nécessaire d'apparition social du droit en tant que pratique sociale de pouvoir et masquage de la violence. Dans la norme nous retrouvons finalement la même structure homologique du fétichisme de la formemarchandise décomposé par Marx dans le livre I de Le Capital. C'est dans l'apparition fétichiste du droit, se présentant comme ensemble de normes juridiques (dans la production législative, dans la dogmatique et dans la décision), se manifestant comme une entité métaphysique autonome et indépendant pour ceux qui l'« élaborent », l' " interprétent », l' « appliquent » ou qui seraient leurs « destinataires », qu'on décourvrira enfin le fondement de l'efficacité idéologique du droit, condition de possibilité même de l'occultation de son essence de praxis de pouvoir et cachement de la violence.

Mots-clés: Droit Privé. Normativisme. Positivisme. Récits juridiques. Représentations sociales du droit. Imagination juridique. Droit et Théorie Littéraire. Individu abstrait. Norme juridique. Système juridique. Communauté interprétative. Droit et en interprétation. Forme-marchandise. Marxisme. Théorie Critique du Droit. Philosophie du Droit. Théorie Générale du Droit. 


\begin{abstract}
Alberto Alonso Muñoz. Philosophical Foundations Models of Private Law and their Limits: a Contribution to the Criticism of Private Law. 2015. 172 p. Ph.D. thesis. Law Faculty, University of São Paulo, 2015.

In this work, using as a methodological strategy a critic ideological exposition of four theories which want to discover the "philosophical foundations of Private Law", we show that this "branch" of law is actually supported by a set of narratives around at least four figures of the abstract individual of bourgeois ideology. These image-narratives, discussed with the tools of literary theory, are characterized and take effect rather by their blanks, silences and omissions than by their positive content (that is, by the abstraction of the socio-historical concreteness) and compose a social representation that ideologically guide the Private Law practices, including the preparation of legislative standards, its dogmatic interpretations and the judicial decisions which presents themselves as the application of legal rules. The legal rule will no longer be seen as the basic atom of the law as a system (the classic conception that constitutes the minimum core of the various theories in the positivist tradition), but the necessary mode of social manifestation of law as a social practice of power and masking of violence. In the legal rule we finally find the same homological structure of the commodity-form fetishism analyzed by Marx in the first volume of The Capital. It is in the fetishist appearance of law, which presents itself as a set of legal rules (in the legislative production of legal standards, in the dogmatic interpretation of law and in the judicial decision) and which manifests itself as a self-contained and independent metaphysical entities for those who would "elaborate", "interpret" or "apply" them, or even would be their "recipients", that we will finally discover the condition of possibility of law ideological effectiveness, the condition itself of the concealing of its essence as power praxis and violence hiddenness.
\end{abstract}

Keywords: Private Law. Normativism. Positivism. Law narratives. Social law representations. Law imagination. Law and Literary Theory. Abstract individual. Law rules. Law system. Interpretative community. Law and interpretation. Commodity-form. Marxism. Critical Legal Theory. Philosophy of Law. General Theory of Law. 


\section{SUMÁRIO}

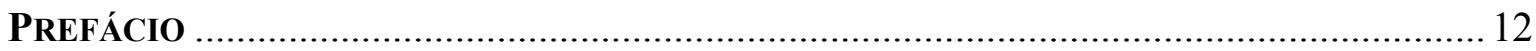

CAPÍTULO 1: O RETRATO DE UM HOMEM AUTÔNOMO....................................................... 18

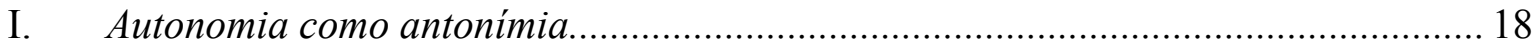

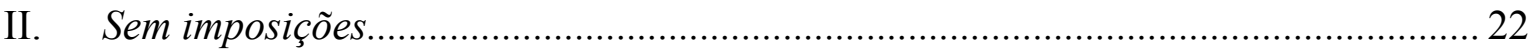

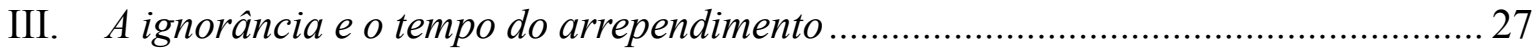

IV. Autonomia, espontaneidade, culpa e responsabilidade vinculante........................... 32

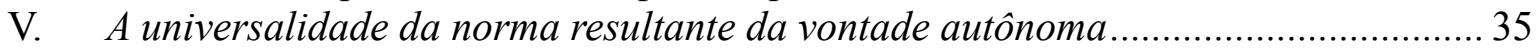

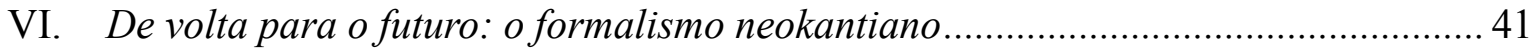

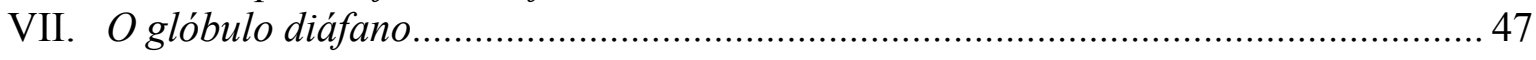

CAPÍTUlo 2: O RETRato de um Homem que Calculava ........................................... 50

I. Haplologia do átomo e partição da subjetividade ................................................. 50

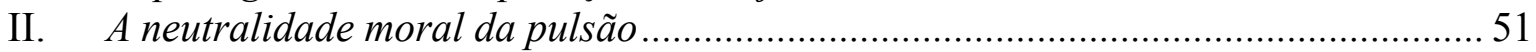

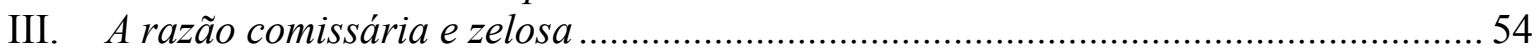

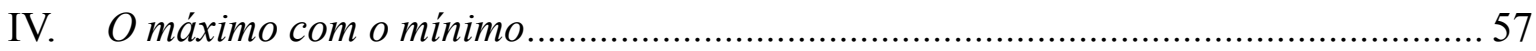

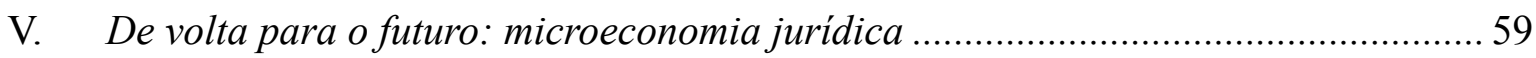

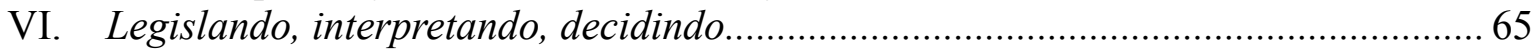

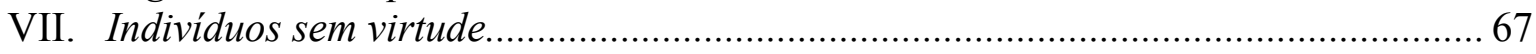

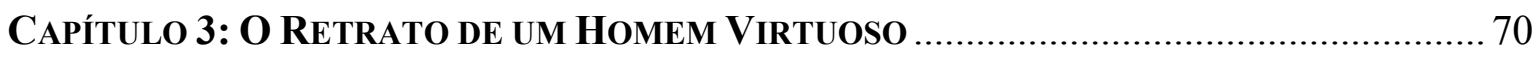

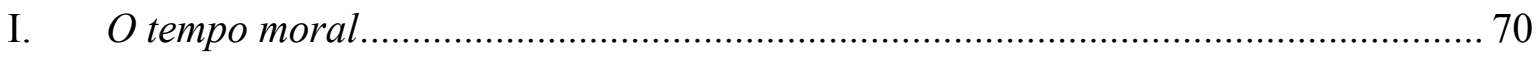

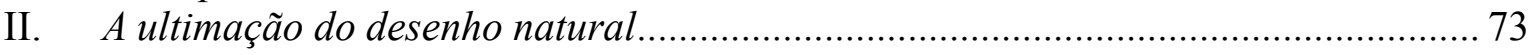

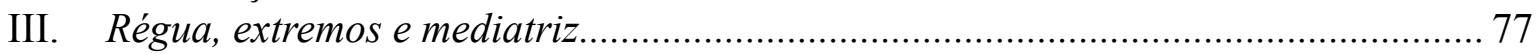

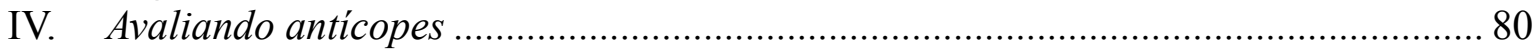

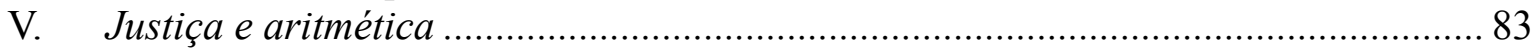

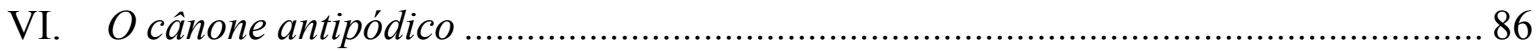




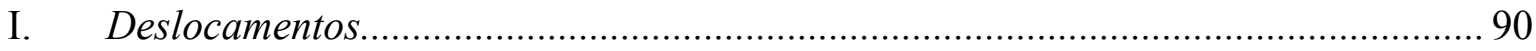

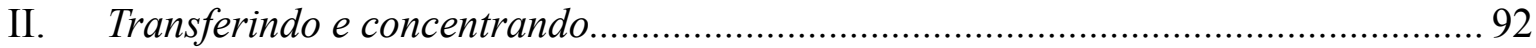

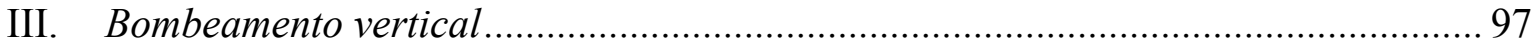

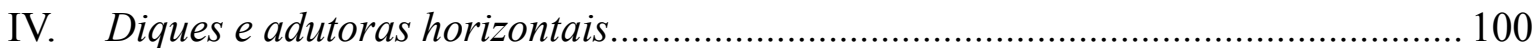

V. Estática e dinâmica de uma hidráulica jurídica ................................................... 105

Conclusão: Retratos: Para a Crítica das Filosofias do Direito Privado .... 112

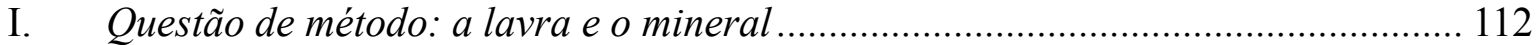

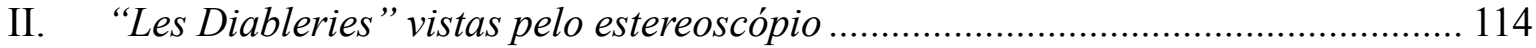

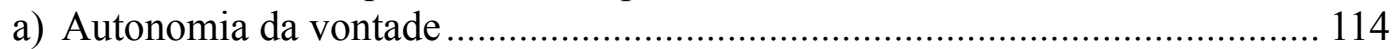

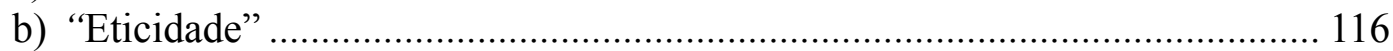

c) "Função social" como "Fim econômico" ....................................................... 118

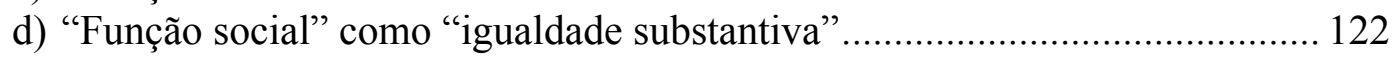

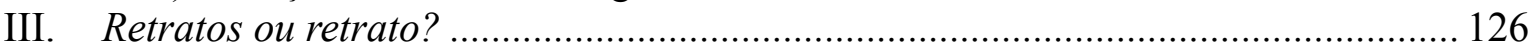

IV. Inércia instuticional, "comunidade interpretativa" e autorreferencialidade

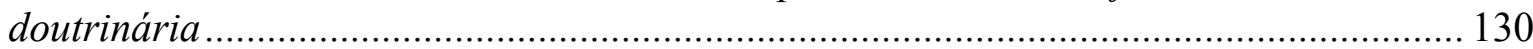

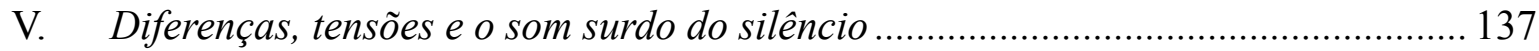

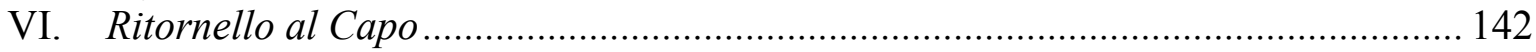

Epílogo: MÉTodo e ObJeto na CrítiCa do Direito ............................................. 145

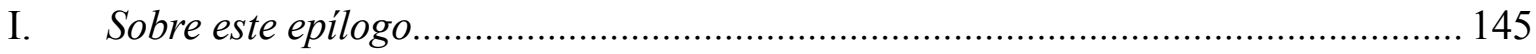

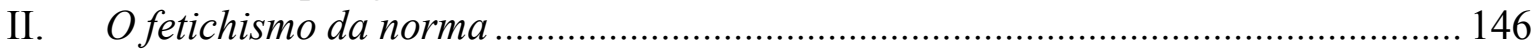

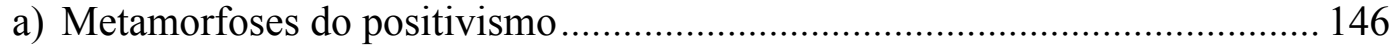

b) Nomocentrismo e ideologia jurídica.................................................... 150

c) Gênese e persistência de uma ilusão: forma-mercadoria e forma jurídica ..... 155

III. Direito como interpretação em construção? ............................................................... 160

IV. Direito como norma, como práxis e como ideologia .............................................. 163

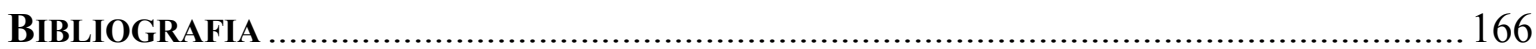


Pelos olhos de Eleonor, que, dizem, são os do pai. 


\section{Prefácio}

O trabalho que ora se tem em mãos não é, nem pretende ser, de maneira nenhuma, mais um comentário à obra dos autores clássicos ou contemporâneos nele mencionados. É bem sabido que os trabalhos dessa espécie oscilam entre um máximo e um mínimo. No patamar máximo, onde se encontram os mais notáveis, eles identificam questões e problemas na obra de um autor (às vezes reais, mas nem sempre) e lhes fornecem, a partir dos recursos argumentativos de sua própria obra, uma solução plausível. Ainda neste ponto mais elevado estão aqueles que buscam inseri-la num debate crítico anterior e posterior ou descrever as condições culturais, históricas e sociais de onde a obra emergiu. Se esse é o pináculo, no vale situa-se um vastíssimo repositório de trabalhos que não vão além de glosas parafrásticas intermináveis e monotonamente enfadonhas das obras dos clássicos ou que se reduzem, no limiar mais baixo de todos, a coleções de citações justapostas, escolhidas de autores os mais díspares, fora de seus contextos e freqüentemente incompatíveis entre si. Esta não pretende ser, portanto, uma "tese de autor" em nenhum desses sentidos: não é uma investigação sobre a teoria da justiça ou do direito de clássicos como Aristóteles, Tomás de Aquino, Kant ou Bentham; e menos ainda uma "reconstrução do debate" em torno das "contribuições" de autores como Ernst Weinrib, Richard Posner, James Gordley ou Anthony Kronman. Será desnorteante e contraproducente que o "benévolo e paciente leitor" exija deste trabalho algo que desde o início não pode nem pretende fornecer.

Por outro lado, este trabalho deseja cometer uma dupla e pretensiosamente ousada heresia. A primeira consiste em pretender apresentar uma teoria do "Direito Privado"1

\footnotetext{
${ }^{1}$ Não definiremos a expressão, deliberadamente. Boa parte deste trabalho é dedicada a, justamente, triturar metodologicamente aquelas que se candidatam a ser suas melhores "definições filosóficas".
} 
— a crítica à utilidade, ainda hoje, dessa categoria, como se verá, não passa despercebida das páginas que se seguem: é antes um de seus temas centrais — que, recusando desde o início admitir a teoria formalista (ou "positivista", ou ainda "normativista", como se quiser) do direito e seu postulado fundamental (o direito como um sistema, cujo elemento mais fundamental é a norma, e que se constrói unicamente a partir dela), o concebe como uma prática de poder determinada por uma representação social. A segunda, ainda mais gravemente pretensiosa, consiste em propor a extensão dessa tese e sugerir que o próprio direito venha a ser assim concebido e examinado. Daí a razão de as teorias dos autores mencionados neste trabalho sejam tomadas apenas instrumentalmente. Porque, na sua radicalidade, elaboraram teorias conduzindo ao mais alto grau de sistematicidade e abstração filosófica o projeto de "fundamentação do Direito Privado", eles, retrospectivamente, lançam luz sobre as representações sociais que, pressupostas na prática desse "ramo" do direito, guiam sua produção.

Tais teorias, portanto, para servir-nos de uma metáfora metodológica, constituem para nós exclusivamente "pontos focais" a partir de onde se ilumina o Direito Privado como prática de poder e que nos servirão para expor à luz o núcleo dessa representação social antinômica, nebulosa e dúbia que o constitui e o norteia. Essa pequena astúcia as revelará, por fim, apenas como mais outras construções ideológicas que, retrospectivamente, ao apoiarem-se em reelaborações filosóficas dessas mesmas imagens-narrativas - que conceituam, precisam e desenvolvem argumentativamente — pretendem justificar o "ramo" do direito encarregado de "disciplinar as trocas patrimoniais". Em razão disso não é objetivo deste trabalho "testar argumentativamente" — como se costuma dizer hoje em dia - as quatro "filosofias do Direito Privado" de maior destaque na atualidade. Trata-se de antes de expô-las e contrapô-las reciprocamente, triturá-las dialeticamente para tentar, a partir delas, arrancar-lhes seu conteúdo de verdade. Justamente por isso este trabalho se nega a integrar o borbotão de inúmeros outros que se propõem

De toda forma, cabe notar que o "Direito de Família" ou o "Direito das Sucessões", topologicamente inseridos atualmente no Código Civil, alinhavam narrativas e imagens ideológicas que estão fora dos limites deste trabalho. Na linha dos autores cujas teorias elegemos como paradigmas aqui, o Direito Privado será encarado a partir dos núcleos da Teoria das Obrigações (especialmente, a partir daí, da responsabilidade civil e da teoria dos contratos) e da disciplina da propriedade e demais institutos que gravitam em torno dela (posse, garantias, direitos reais de modo geral). Num trabalho como este, portanto, não é possível pedir uma definição do que signifique "Direito Privado" (e menos ainda, o que é mais grave, do que possam significar as palavras "dialética" ou "ideologia"). O contexto argumentativo deve ser suficiente para compreender-se do que estamos tratando a cada momento e de que maneira, sem exigirem-se definições muito a gosto do estilo da filosofia analítica angloamericana. 
debatê-las. Elas chamam a atenção porque, como discursos ideológicos legitimatórios do Direito Privado, se oferecem para nós - repitamos - como instrumentos ou plataformas de observação desse "ramo" do direito, e nada mais além disso.

A palavra "representação" (social), que pode suscitar imediato alarme naqueles dentre nós dotados de um olfato filosófico mais apurado, não deverá causar maior estranheza. Não deve comprometer-nos com uma filosofia "da representação" ou "da consciência". Não é, por óbvio, uma "impressão" ou "imagem”, interna à esfera da subjetividade e que mantém alguma espécie de relação (de "cópia", de "expressão", de "similitude", de "mera referência", de "correspondência" enfim) com um objeto exterior. Ela é social no duplo sentido dessa palavra: não só porque pretende narrar, de modo vago, lacunoso, prenhe de silêncios e relativamente simples (e tem de ser assim para poder ser operacional, como se constatará em suas "figuras" mais básicas), a estrutura da vida social, mas também porque é ela própria social, no sentido de ser produto social e dotada de um conteúdo igualmente social. ${ }^{2}$

A representação social que encontraremos dirigindo o Direito Privado apresentanos uma figura abstrata da natureza da sociedade e de suas relações. Esse elemento fundamental a partir do qual é composta essa percepção da sociedade a partir do olhar do Direito Privado compõe uma imagem-diretriz alinhavada por narrativas, que ora vem à tona mais ou menos expressamente, ora permanece submersa, mas sempre servindo como condutor da prática jurídica. Digamos, para retomarmos a este conceito clássico, que se trata da consciência social presente na prática jurídica, que, quando alcança determinado nível de engenhosidade e sofisticação, pretende alçar-se a uma "filosofia" do Direito Privado. Ela projeta sobre a sociedade uma fantasmagoria que, a partir daí, passa a substituir-se a ela e a apresentar-se no lugar da própria sociedade. Ela o faz por meio de uma forma normativa, mecanismo essencial pelo qual se cria a fantasmagoria da independência do direito frente a seu intérprete ou aplicador. Ela permite organizar num sistema, através do papel consciente da dogmática jurídica, e, com base nela, mais ou menos tateante da atividade jurisprudencial (e também legislativa), o próprio conteúdo ide-

\footnotetext{
${ }^{2} \mathrm{O}$ conceito de "representação social" aqui tomado é descompromissadamente próximo ao sugerido por Terry Eagleton para a análise da obra literária: "Em qualquer texto, os significados que ele transforma em ficção são antes representações da realidade do que a realidade ela própria. O texto é um tecido de significados, percepções e respostas que pertencem, em primeiro lugar, à produção imaginária do real que é a ideologia" (Criticism and Ideology: a Study in Marxist Literary Theory. Londres: Verso, 1976, p. 75). Eagleton apóia-se em George Lukács, Fredric Jameson e Pierre Macherey (destes dois últimos, em particular, herda a atenção para as "ausências", o "não-dito", os "silêncios" do texto e sua construção ideológica da realidade por meio deles). Voltaremos a esse conceito ao
} 
ológico do Direito Privado. Ela realiza a mediação ideológica interna ao direito entre este como técnica e este como decisão de poder.

Este trabalho parte de uma escolha metodológica: a de que seja possível se valer de alguns instrumentos analíticos de certas correntes da teoria literária contemporânea para a análise do texto normativo, do discurso dogmático, da decisão e da prática do direito de modo geral. Desde Dworkin ao menos a colaboração entre a filosofia do direito e a teoria literária deixou de ser um paradoxo. Até então, o direito socorria a teoria literária apenas quando era necessário compreender, num texto, um elemento histórico nele contido. A filosofia do direito sempre preferiu freqüentar as casas de campo da filosofia da linguagem ou da filosofia da lógica — gente séria e elegante — ou desenvolver uma hermenêutica própria e autônoma, a correr o risco de ser flagrada no sobrado muito malafamado da teoria literária. O mérito desse autor — que, nisso, não é pequeno — está justamente em ter ousado empregar a teoria literária (ou antes, uma teoria da interpretação do texto literário muito específica) na construção de uma teoria "interpretatista" ${ }^{3}$ do direito. Ao concluir que a produção jurídica é um "texto inacabado" ou em permanente processo de elaboração, Dworkin fez avançar a compreensão do direito, que se revela agora ser uma prática, práxis decisória, e não mais um sistema de normas. No entanto, não tentando ultrapassar as fronteiras de um certo liberalismo jurídico, ainda que reconhecidamente muito refinado, o direito é, para ele, a construção de uma tradição jurídica. Restou-lhe, porém, uma crítica da própria representação que guia essa prática. Eis o que entendermos ser necessário sugerir neste trabalho, ensaiando aqui os primeiros resultados mais gerais de uma análise das representações sociais que guiam a produção do Direito Privado a partir de sua ideologia.

Desde que se tornou hegemônico entre nós o estilo acadêmico norte-americano, o cânone do gênero impõe que se concluam as introduções com gigantescas listas de nomes em agradecimento. O comum é que muitas menções sejam apenas protocolares; várias, exclusivamente estratégicas. Umas poucas costumam ser efetivamente sinceras. Já se disse uma vez que em tais elencos dizem mais o silêncio, a ausência e a omissão do que a presença, como aquela regra da hermenêutica jurídica clássica que mandava atentar para o "silêncio eloqüente do legislador". É certo que no trabalho intelectual basta

${ }^{3}$ O termo "interpretatista", por oposição a "interpretativista", é de Ronald Dworkin. 
uma frase lançada despretensiosamente num encontro fortuito para que muita coisa venha a ser mudada ou muita coisa venha a se ajeitar. Agradeço sinceramente a todos que contribuíram - com consciência ou não, tanto deles quanto minha — seja para as reflexões registradas neste trabalho, seja propiciando as "condições objetivas" sem as quais, como é bem sabido, nenhum trabalho intelectual consegue ser realizado.

Ainda que rompendo com as regras desse novo estilo e tentando continuar o melhor daquela nossa antiga tradição européia, em franco processo de triste esquecimento, não quero, porém, deixar de mencionar algumas instituições e pessoas. Este trabalho é produto de dois universos acadêmicos muito distintos, antagônicos e provavelmente inconciliáveis, repletos de mal-entendidos recíprocos: a Faculdade de Filosofia, Letras e Ciências Humanas e a Faculdade de Direito do Largo de São Francisco, as duas instituições da Universidade de São Paulo a quem devo o que creio ser o melhor da minha formação. É um trabalho que nasceu e se formou assistindo os viajantes se dispersarem na encruzilhada desses dois caminhos. Sabemos que há quem considere que trabalhos assim - horrivelmente denominados de "interdisciplinares" e tenebrosamente classificados como postos "na interface" de "campos teóricos" distintos — não conseguem ser compreendidos por ninguém além dos poucos privilegiados que conhecem bem os dois mundos. Leitores comuns decifrariam a metade, quando muito, por não disporem de todo o arsenal. Aliás, há mesmo quem vá além e afirme que padecem de superficialidade e falta de seriedade, já que se recusariam à submersão vertical no setor de certa "especialização".

Metáforas geográficas ou geométricas desnorteiam mais do que auxiliam (o rigor manda empregar "aresta", não "interface", termo da hora). É certo que a setorialização do saber, cuja primeira formulação ideológica talvez remonte ao positivismo comtiano, sepultou, a partir da segunda metade do século XIX, o espírito enciclopédico da modernidade, nascido na Renascença e erguido com o empenho de gerações como padrão intelectual durante o Iluminismo. ${ }^{4}$ A setorialização, a departamentalização e o discurso da especialização, por razões várias que não é possível aprofundar, passaram a ser a regra na Universitas e atingiram seu apogeu na segunda metade do século XX com a crise fi-

\footnotetext{
${ }^{4}$ A esse respeito, para uma análise a partir de Bourdieu, confronte-se a descrição de Jean Louis Fabiani em seu livro Les philosophes de la Republique (Paris, Editions de Minuit, 1988) das transformações da produção filosófica francesa no final do século XIX, com a profissionalização impondo a especialização institucional e seus correspondentes rituais (concursos, conferências solenes, defesas de teses, entre outros). E ainda, na mesma linha, mas agora para a conformação do campo após os anos setenta, Louis Pinto, La vocation et le métier de philosophe. Pour une sociologie de la
} 
nal desse modo de produção do saber numa fragmentação subatômica da pesquisa em todas as "áreas". 5 Ao mesmo tempo, as condições sociais e institucionais que permitiam a existência de uma plataforma de observação, do "ponto de vista da totalidade", se tornaram cada vez mais escassas ou simplesmente desapareceram. O autor deste trabalho ficará contente se não se exigir de suas páginas o mesmo que se espera de um mapamúndi pós-soviético, mas se forem compreendidas talvez como um amálgama ou como a sobreposição de camadas de uma liga metálica. E, principalmente, se tampouco forem tratadas como um trabalho "no terreno" ou "no campo" da filosofia, da teoria literária, da sociologia, da teoria política, da história, da psicologia, do direito — da "filosofia do direito" - , ou de quantos outros mais houver.

Os professores Tércio Sampaio Ferraz Júnior e Alberto Amaral Júnior leram com o rigor e atenção que lhes são característicos o texto (bem diferente deste, como irão notar) que lhes apresentei para o exame de qualificação. Tentei responder a suas preciosas observações, críticas e sugestões — cruciais naquele momento ainda embrionário da evolução deste trabalho - nas páginas que seguem ou ao menos contorná-las tomando algum atalho. A esses meus dois primeiros e notáveis debatedores, fica aqui o registro do profundo agradecimento.

Ronaldo Porto Macedo Júnior, meu orientador e amigo, com quem discuto e que me ensina filosofia "do direito" há doze anos, admitiu-me mais uma vez na pósgraduação. Devo-lhe não só as tantas portas abertas, mas as muitas fechaduras que tentou obstinadamente destrancar - grande parte delas não intelectuais. Ronaldo e eu somos diferentes e divergimos em muita, muita coisa. Apesar disso, os anos solidificaram uma amizade pessoal que a diferença só não dilui pelo respeito da singularidade alheia. Por tudo isso, o reconhecimento e o agradecimento: aqui, professor Ronaldo, mais uma vez.

Este trabalho é dedicado à memória de Hermes Muñoz Garcia - espanhol, ateu, marinheiro, metalúrgico, comunista —, que, na infância, me contava do Quijote e de um certo "Carlos" Marx.

\footnotetext{
philosophie dans la France contemporaine (Paris, Seuil, 2007).

${ }^{5}$ A esse respeito, acredito correta, apesar de tudo, ainda hoje a lição de George Lukács em El Asalto a la Razón (trad. de Wenceslao Roces. México: Fondo de Cultura Económica, 1959), quando entende a especialização e fragmentação crescentes do saber, especialmente a partir do marco histórico de 1848, como mecanismo a serviço da perda do ponto de vista da totalidade.
} 


\section{Capítulo 1:}

\section{O Retrato de UM HOMEM AUtônomo}

\section{Autonomia como antonímia}

“Autonomia da vontade" é uma das expressões mais correntes na dogmática jurídica do Direito Privado e, de modo mais amplo, na prática jurídica como atividade de justificação discursiva de atos jurídicos de poder. ${ }^{6}$ Longe de ser uma noção filosoficamente neutra (mas também sem nunca chegar a ser burilada filosoficamente até as últimas conseqüências no interior da dogmática jurídica), ela desempenha o papel de um “conceito jurídico-operacional". Alguns exemplos nacionais, dentre os melhores civilistas brasileiros, deixarão claro esse duplo fenômeno, a saber: seu caráter operacional e sua essencial vagueza e equivocidade:

Detendo-nos um instante mais sobre o elemento vontade frisamos que o princípio pelo qual se lhe reconhece o poder criador de efeitos jurídicos denomina-se autonomia da vontade, que se enuncia por dizer que o indivíduo é livre de, pela declaração de sua própria vontade, em conformidade com a lei, criar direitos e contrair obrigações. Mas, por amor à regra da convivência social, este princípio da autonomia da vontade subordinasse às imposições da ordem pública, que têm primazia sobre o primeiro, de

\footnotetext{
${ }^{6}$ As páginas a seguir deste primeiro capítulo padecem, sem dúvida, de uma dupla imperfeição: serão enfadonhas e insuportavelmente monótonas ao leitor filósofo e se mostrarão superficiais, imprecisas e excessivamente esquemáticas ao leitor jurista. A ambos, pedimos paciência: foram pensadas antes e também como uma apresentação preliminar geral ao arcabouço dos "institutos" mais básicos e das operações argumentativas mais elementares do Direito Privado para aquele leitor que não costuma visitar com freqüência o Direito Civil, passo essencial para que se possa prosseguir ao longo deste trabalho. Ao filósofo, pedimos que persevere, sem muito desânimo, no quadro conceitual e na linguagem jurídica, que, sabemos, parecem num primeiro momento girar em falso, em torno de si mesmos, perder-se sem chegar a lugar nenhum. Ao jurista, rogamos vênia com as inevitáveis imprecisões terminológicas, os lineamentos superficiais e a excessiva pressa: de doctrina ergo non tractat.
} 
forma tal que todo reforçamento da ordem pública implica restrição na autonomia da vontade, sendo de assinalar-se que, em nossos dias, vem-se observando, no mundo inteiro, uma cada vez maior expansão do domínio da ordem pública, e um cada vez mais acentuado estreitamento da participação da autonomia da vontade. ${ }^{7}$

O negócio jurídico representa uma prerrogativa que o ordenamento jurídico confere ao indivíduo capaz de, por sua vontade, criar relações a que o direito empresta validade, uma vez que se conforme com a ordem social. A vontade procura um fim que não destoa da lei e que, por esse motivo, obtém dela a eficácia necessária. O fim da declaração é produzir efeitos jurídicos imediatos, e, dada a liceidade do propósito, tais efeitos são efetivamente gerados. A esse princípio se chama autonomia da vontade. Representa a medida na qual o direito positivo reconhece aos indivíduos a possibilidade de praticar atos jurídicos, produzindo seus efeitos. ${ }^{8}$

O negócio jurídico, por ser situação jurídica derivada do elemento volitivo (vontade humana), pertencente à classe dos fatos jurídicos cujo resultado final é pretendido, desejado, pelas partes, tem nítido cunho de satisfação de interesses privados. Logo, a exteriorização da vontade é a nota característica que mais avulta no negócio jurídico. É a sua força propulsora. É preciso aqui registrar, reiterando posição antes evidenciada à exaustão, que o elemento volitivo, fruto da autonomia da vontade e da autonomia privada, marca registrada do negócio jurídico, não mais assume caráter absoluto, sofrendo, sempre, as limitações decorrentes da ingerência de normas de ordem pública, notadamente constitucionais, por força da proteção destinada à pessoa humana, realçando sua necessária dignidade $\left(\mathrm{CF} / 88\right.$, art. $\left.1^{\circ}, \mathrm{III}\right){ }^{9}$

Vale invocar o escólio de Francisco Amaral, para esclarecer que autonomia da vontade e autonomia privada, embora sejam expressões utilizadas por alguns como sinônimas, não se confundem. Autonomia da vontade tem conotação subjetiva, psicológica, dizendo respeito à possibilidade reconhecida ao titular de celebrar, ou não, negócios jurídicos. Já a autonomia privada marca o poder da vontade, sendo concernente ao poder dos particulares de regular, pelo exercício da própria vontade, o conteúdo e disciplina dos negócios que resolverem entabular. ${ }^{10}$

Como se constata, essa noção - melhor desde já: essa imagem — desempenha uma função e opera argumentativamente de determinada maneira. Espera-se dela que organize uma determinada descrição da vida social e, com isso, permita que o direito seja elaborado, no sentido mais amplo possível dessa palavra (tanto a produção primária da norma, quanto, especificamente, a decisão administrativa ou judicial). ${ }^{11}$ Ela é pensa-

\footnotetext{
${ }^{7}$ Caio Mário da Silva Pereira, Instituições de Direito Civil, vol. I (Rio de Janeiro, Forense, 2013), p. 400.

${ }^{8}$ Silvio Rodrigues, Direito Civil - Parte Geral. Vol. I, 34. ${ }^{a}$ Ed. São Paulo: Saraiva, 2014, p. 170.

${ }^{9}$ Cristiano Chaves de Farias e Nelson Rosenvald, Curso de Direito Civil - Teoria Geral. Rio de Janeiro: Lúmen Júris, 9. ${ }^{a}$ Ed., 2011, p. 642.

${ }^{10}$ Cristiano Chaves de Farias e Nelson Rosenvald, Curso de Direito Civil-Teoria Geral, op. cit, p. 1020, nota. Os dois autores, dentre os melhores civilistas brasileiros contemporâneos, param por aí e não prosseguem além disso. E seja-lhes feita justiça: não é dever papel fazê-lo. Como veremos, tais conceitos operacionais só permanecem assim, operacionais, se mantiverem a vagueza e imprecisão de imagens obscuras, breves e repletas de lacunas.

11 "Em geral, no direito privado vigora o princípio da autonomia da vontade, e, nesta órbita, são supletivos ou meramente permissivos os princípios legais, salvo, entretanto, no que o legislador entende interessar à ordem pública, ponto onde começa a incidência das normas inderrogáveis pela vontade privada.” (ainda Caio Mário da Silva Pereira. Instituições, op. cit., vol. I, p. 89.)
} 
da pela dogmática como um "pressuposto" do "sistema de normas", algo para o qual o sistema aponta, o ponto cardeal do qual irradiam os meridianos em que se situam as normas abrangidas pelo Direito Positivo. Ou, numa outra imagem (freqüente na dogmática ao definir-se a noção de "princípio"), como o "ponto de fuga geométrico" ou o "vértice da pirâmide" para o qual convergem as "linhas que desenham o direito". Seu grau de abstração the garantiria assento em todos os contextos normativos do Direito Privado e até mesmo no Direito Público, como a interpretação clássica (e atualmente ultrapassada) de soberania como "autodeterminação estatal” no Direito Internacional Público ou o conceito de "vontade do Estado" ou de "vontade do legislador". ${ }^{12}$ Coroada como garantidora da unidade, completude e coerência desse sistema de normas, ela alinhavaria (num sistema coerente) e cerziria (num sistema completo) um tecido jurídico de outra forma destinado a ser uma malha onde haveria mais vazios do que nós. ${ }^{13} \mathrm{Se}$ o Direito Privado é como é, e, mais ainda, é um ramo "autônomo" do direito, é porque corresponderia isomorficamente à "sociedade civil" nela "representada". 14

Essa noção, cujos contornos filosóficos na modernidade se costuma fazer remontar a Kant, é desenvolvida conceitualmente na dogmática e nos textos legais a partir de uma operação por antonímia. A autonomia da vontade - como veremos numa aproximação filosoficamente mais rigorosa que lhe será apresentada por alguém que ela seja o fundamento filosófico do Direito Privado - é o que ela não é. A estrutura do argumento, que na verdade remonta historicamente à primeira sistematização da liberdade individual como não-coação e não-ignorância na primeira metade do livro III da Ética a $\mathrm{Ni}$ cômaco de Aristóteles, focaliza inicialmente a ação do indivíduo isolado e, a partir daí, procura descobrir os fatores internos e externos que afastam a responsabilidade moral

\footnotetext{
${ }^{12}$ A concepção hobbesiana e neohobbesiana do ambiente internacional como composto de Estadosindivíduos em "estado de natureza" é insuficiente porque simplificadora e só se mostra sedutora na exata medida em que é obrigada a deixar de lado fenômenos com os quais se mostra incompatível, especialmente com a relativização dos princípios preponderantes desde os tratados de Vestfália. A esse respeito, veja-se a reconstrução da crítica por Alberto Amaral Júnior, Curso de Direito Internacional Público (São Paulo: Atlas, 3. ${ }^{\mathrm{a}}$ Ed. 2012), p. 1-42.

${ }^{13}$ Veja-se, a esse respeito, desde já, Ernst Weinrib, The Idea of Private Law. Oxford: Oxford University Press, 2012, p. 32-36.

${ }^{14}$ A noção de "autonomia" do Direito Privado - que, aliás, lhe garante até um nome: "Direito Privado" - é controversa, como se sabe, a partir do que a doutrina passou a chamar de "fenômeno da publicização". A dogmática civilista, pelos mais variados motivos, insiste na relativização, ao mesmo tempo que também renhidamente na "independência" desse "ramo". Mais uma vez, não se vai além de certo patamar de aprofundamento no debate. Um autor como Ernst Weinrib (na direção do qual giraremos o farol em alguns instantes), pretendendo conferir clareza à imagem que essa noção desenha, sustentará, com especial ênfase, a independência desse ramo. Veja-se desde já Ernst Weinrib, The Idea of Private Law, op. cit., p. 204-231.
} 
do agente pela ação praticada. ${ }^{15}$ Ausentes tais elementos, o agente é considerado responsável, pois a ação decorreu de um agente não-heterônomo, ou seja, de um princípio que se encontrava nele próprio, e não fora dele: sua vontade autodeterminada. A autonomia da vontade, dessa forma, aparece como conceito negativo, como o antônimo da vontade heterônoma, o negativo, o fototipo ou clichê do componente social mais elementar de todos, resultante da decomposição lógica da vida social na peça mais básica da representação da sociedade.

A partir daí, traduzidos agora pela dogmática civilista do século XIX e primeira metade do século XX numa reformulação neokantiana, alguns dos conceitos da Fundamentação da Metafísica dos Costumes reapropriados no campo do direito reaparecem com ora maior, ora menor requinte teórico nos livros da doutrina jusprivatística. Referências à "autonomia da vontade" como fundamento da liberdade de contratação e da responsabilidade do indivíduo autodeterminado alicerçam uma massa gigantesca de decisões judiciais (justapostos a outras imagens francamente incompatíveis, como "eficiência", "caráter honesto" e "proteção à parte mais fraca"), de pareceres, de exposições de motivos e outros tantos atos da vida jurídica. Os três excertos doutrinários acima, em livros destinados ao iniciante e escritos por civilistas consagrados, são apenas uma ilustração mínima do emprego desse conceito, de maneira operacional - a função de com ele fundamentar decisões e soluções — na dogmática e na jurisprudência.

O quanto essa representação é a candidata vencedora ao papel de organizar a prática jurídica, ou seja, o quanto ela é a luva perfeitamente ajustada à mão que pretende calçar, é uma questão de pouca importância. Nada impede, como mostraremos nas páginas a seguir, que coexistam representações contraditórias e em tensão a guiarem a prática jurídica no domínio do Direito Privado. A coerência não é, aqui, nem característica, nem condição necessária ou suficiente da prática nesse "ramo" do direito. Antes, a própria condição de existência do Direito Privado, entendido como prática decisória guiada por uma representação social, é a convivência de imagens contraditórias. As páginas que se seguem exporão, em linhas gerais, as quatro principais teorias filosóficas que pretenderam demonstrar que existe um conjunto de pressupostos que fundamentariam, em última instância, o "Direito Privado". Seu exame, restrito aos propósitos deste trabalho, revelará a existência, com maior ou menor grau de complexidade e consistência, das diversas figuras da consciência jurídica jusprivatística, as primeiras dramatis per-

\footnotetext{
${ }^{15}$ A esse respeito, permito remeter para o meu Liberdade e Causalidade: Ação, Responsabilidade e
} 
sonae dessa narrativa. ${ }^{16}$

\section{Sem imposições}

A dogmática jurídica dos séculos XVIII e XIX encarregou-se de sistematizar as condições pelas quais uma manifestação da vontade seria autônoma, portanto, responsável, e, por conseguinte, vinculante, no sentido jurídico da palavra. ${ }^{17}$ A primeira delas, a mais essencial de todas, consiste na ausência de qualquer espécie de coerção da vontade, uma versão, como já antecipamos, "em negativo" das condições clássicas que excluíam a responsabilidade. Reelaborada em seu máximo refinamento filosófico, como já mencionamos, na Fundamentação da Metafísica dos Costumes, estará na base da afirmação de que alguém só está moralmente vinculado "a sua própria legislação", àquilo que a vontade "se impõe como norma", justificando a ação coercitiva do direito e do Estado na proteção de seus "efeitos jurídicos". Retornaremos aos detalhes da Fundamentação da Metafísica dos Costumes mais adiante, num momento que, em instantes, nos conduzirá à primeira personagem das "filosofias contemporâneas do Direito Privado". Por ora, basta-nos destacar que uma manifestação de vontade é vinculante somente se ela de fato fosse uma manifestação da vontade. Do contrário, ainda que seja uma manifestação, o comportamento não seria produto de uma vontade autônoma, mas "heterônoma" e, assim, não poderia ser acolhida como produtora de efeitos a ele imputáveis.

Sabemos que a dogmática, especialmente a civilista, encarregou-se de sistematizar esses que constituem os "vícios do consentimento" (ou "da vontade"), e que, enquanto tais, afastariam a responsabilidade. Ainda que haja manifestação — isto é, uma ação por parte daquela pessoa, natural ou jurídica - que, restrita a seu exame, poderia conduzir à vinculação daquele que a manifestou com o direito subjetivo da parte oposta, é necessário como que passar a um segundo plano, propriamente "essencial", em que se examinam não só as condições da prática do ato jurídico, ${ }^{18}$ mas também da "subjetividade"

Metafísica em Aristóteles (São Paulo: Discurso Editorial, 2001).

${ }^{16}$ A expressão é empregada por Marx em $O$ Capital (veja-se, mais adiante neste trabalho, o texto citado à p. 109): à narrativa do homem livre, igual, proprietário e egoísta opõe-se o contraste com a realidade da compra e venda da força no mercado da força de trabalho.

${ }^{17}$ Uma das melhores descrições do processo está em Franz Wieacker, História do Direito Privado Moderno (Lisboa: Fundação Caloustre Gulbenkian, 1967), p. 430-491, cujos resultados de sua análise histórica estão pressupostos nas páginas que se seguem.

18 “Ato", e não "negócio", naturalmente, pois aqui o que se trata é de examinar seus efeitos, o que envolve também a responsabilidade civil extracontratual por ato ilícito. O Código Civil de 2002, para a crítica de parte da doutrina civilista, substituiu "ato" por "negócio". A categoria de "ato", porém, parecia mais ampla e abrangia condutas a que o direito atribuía "efeitos", mesmo que contrariamente 
daquele que o praticou. Dito de outra forma, é necessário, para saber-se se, por exemplo, o negócio jurídico produz efeitos, ultrapassar o nível da mera declaração e examinar as condições em que ela é enunciada. Como é impossível conhecer diretamente a subjetividade do agente - e especialmente não só é impossível, como sem sentido quando se trata de pessoas jurídicas (que, por definição, não possuem “subjetividade", no sentido psicológico da palavra) - é a partir do contexto, das circunstâncias, que se identificará se a "vontade" foi efetivamente autônoma ou se foi "determinada" por alguma coisa fora dela própria. Portanto, por contraste, se não estiverem presentes as condições que excluem a determinação externa da vontade, então a vontade será considerada presente, autônoma. Como veremos, muito mais do que simplesmente ser condição do nascimento da obrigação, da responsabilidade, do dever e do direito subjetivo, ela é, do ponto de vista dessa concepção vagamente "neokantianizante"19 do Direito Privado, o próprio fundamento último de seu conteúdo — o próprio núcleo que permitiria organizar esse setor do direito.

A "coação" como vício paradigmático da vontade (do "consentimento", no rigor da terminologia civilista) é tomada, então, como protótipo das demais condições que, se preenchidas, afastam a autonomia. Ela constitui uma circunstância fática que produz uma emoção (passio) específica: o "temor de dano iminente e considerável à sua pessoa, à sua família, ou aos seus bens" (Código Civil de 2002, art. 151). O medo, o temor, como elemento que, interferindo na vontade, a captura, subjugando-a a um senhor exterior a si própria, exclui a responsabilidade e, a partir daí, a vinculação aos efeitos da obrigação. Submetida a um senhor exterior a si própria, a vontade não é livre, não é autônoma. Não o sendo, ou melhor, sendo "heterônoma", tendo sua norma provindo não dela própria, mas de outro, não vincula o autor da manifestação "de vontade". As aspas devem ser consideradas: não há vontade livre, ou ainda, simplesmente, não há vontade.

O temor de que o dano lhe seja causado deve ser "fundado" e o dano, "iminente e considerável”. Fundado, ou seja, por oposição a "infundado", deve ser razoável pensar

à vontade de terceiros (na responsabilidade civil extracontratual, na gestão de negócios, no abuso do direito de propriedade, no enriquecimento sem causa, por exemplo).

${ }^{19}$ O termo "neokantiano" deve ser atribuído à filosofia do Direito Privado, e não como se referindo às escolas filosóficas do início do século XX (Escolas de Baden e de Marburg), com as quais, aqui, não mantém absolutamente nenhuma relação. O núcleo da estratégia é encontrar em Kant, como faz Weinrib, a formulação mais rigorosa e elaborada do conceito da autonomia da vontade, que originaria o princípio correlato que sistematizaria o Direito Privado (Weinrib prefere "inteligibilidade interna"). Sobre as duas escolas mencionadas e seus respectivos conceitos de sistema do direito, veja-se Tércio Sampaio Ferraz Júnior, Conceito de Sistema no Direito (São Paulo: Revista dos Tribunais, 1976), p. 39-69. 
que, naquelas circunstâncias, o dano irá ocorrer. E deverá ser "iminente" (em tempo breve) e "considerável”, ou seja, não pode ser irrisório ou nulo. A vida, a integridade física, o patrimônio, a posição social, etc., são os exemplos doutrinários mais constantes. $\mathrm{O}$ art. 152 do Código Civil descreve, ainda, alguns dos elementos do contexto fático em que a coação é exercida e que devem ser considerados: “o sexo, a idade, a condição, a saúde, o temperamento do paciente e todas as demais circunstâncias que possam influir na gravidade dela”. Claro que a cláusula legislada é deliberadamente vaga, e isso, diversamente do que se poderia pensar a início, não é devido à técnica legislativa empregada no Código Civil de 2002. Em 1916, o dispositivo dizia que o dano, para anular o ato, deveria ser "igual, pelo menos, ao receiável do ato extorquido". E mantinha também a referência às circunstâncias que devem servir para avaliar a presença ou não do "fundado temor". Registremos esse fenômeno e deixemo-lo separado sobre a mesa: será útil mais adiante.

O essencial nesse retrato é a presença de um temor tal que impeça aquele que age de não agir dessa forma, ou que o force a fazê-lo. Um fator externo produz um efeito subjetivo no agente que lhe impõe uma conduta, positiva ou negativa. Por conseguinte, não se pode dizer que foi o agente quem agiu. Ou melhor, sequer se pode falar aqui em “ação", se por este termo se entender um comportamento humano determinado pela vontade. A imagem assim elaborada é a de um indivíduo cuja vontade é obrigada a sujeitar-se a um senhor circunstancial exterior e, dessa maneira, não pode ser responsabilizado pelos próprios atos. No momento em que o indivíduo é dominado por um fator externo a ele próprio, não pode produzir uma lei que determine seu comportamento. Não é, diz essa imagem, livre, não dá a si própria sua lei:

Porque, se nos limitávamos a conceber o homem como submetido a uma lei (qualquer que ela fosse), esta lei devia ter em si qualquer interesse que o estimulasse ou o constrangesse, uma vez que, como lei, ela não emanava da sua vontade, mas sim que a vontade era legalmente obrigada por qualquer outra coisa a agir de certa maneira. ${ }^{20}$

Determinado por outro e não por si próprio, não se pode dizer que o agente se autoimpôs um comando, ou, melhor (e etimologicamente falando), uma norma (autonomia). O comando foi-lhe imposto externamente, na forma de uma imposição tal que não havia opção possível. Ou melhor, havia, porém a um custo "igual, pelo menos, ao receiável do ato extorquido" ou, se preferirmos (e ponderando o contexto), “considerável”, o que só o herói ou o louco, como apontava Aristóteles, escolheria fazer. Ou em "legítima

${ }^{20}$ Kant, Fundamentação da Metafísica dos Costumes (Trad. Paulo Quintela. Lisboa: Edições 70, 
defesa" contra ato de outrem. Ou ainda expressamente no prejuízo causado a coisa alheia, "a fim de remover perigo iminente".

O protótipo da coação reaparece em outras figuras menores dos "vícios do consentimento", como o "estado de perigo" e a "lesão", que o Código Civil de 2002 absorveu (arts. 156 e 157), após sua preterição no Código de 1916. As figuras não são novas, podendo ser encontrados seus primeiros vestígios no Direito Romano e seu desenvolvimento no Direito Canônico da Idade Média. A inovação está na sua introdução no Código Civil de 2002, o que revela uma alteração no retrato-padrão do "homem jusprivatístico”, ou a presença de outros retratos. No século XIX, sob o predomínio do liberalismo, apenas a figura da coação, e ainda assim sujeita à cláusula "igual, pelo menos, ao receiável do ato extorquido" (o arcaísmo "receiável" é o do Código de 2002), podia ser admitida. As novas figuras admitem que a "posição de inferioridade" do agente nas circunstâncias pode autorizar a anulação do negócio jurídico. ${ }^{21}$ Aqui a ameaça não é direta, mas indireta, resultando das circunstâncias em que o agente se encontra. No primeiro caso, o agente assume obrigação excessivamente onerosa, obriga-se por quantia superior àquela que algum padrão de razoabilidade (em regra, as condições normais de mercado fora de circunstâncias excepcionais). Essa obrigação é afastada (é "anulável") quando a outra parte está ciente de que aquele que contraiu a obrigação se encontrava "premido" (veja-se novamente o "fundado temor") "da necessidade de salvar-se, ou a pessoa de sua família, de grave dano" (veja-se novamente o "dano iminente e considerável"). Se na coação alguém diretamente exerce sua ameaça sobre o agente, afastando sua vontade, aqui se vale de meios indiretos. Se no primeiro caso o gesto é positivo (uma ameaça), aqui é negativo (uma abstenção, condicionada a uma obrigação).

$\mathrm{Na}$ lesão, figura mitigada do estado de perigo, a mesma estrutura se repete: a necessidade de "salvar-se, ou a pessoa de sua família, de grave dano" é substituída pela "premente necessidade, ou por inexperiência" (este último caso será examinado no item a seguir). A “obrigação excessivamente onerosa” é substituída pela obrigação "a prestação manifestamente desproporcional ao valor da prestação oposta", que será estimada não em circunstâncias normais, mas "segundo os valores vigentes ao tempo em que foi celebrado o negócio jurídico" (art. 157 do atual Código Civil, caput e $\S 1$ 1. $^{\circ}$ ). Ainda aqui o coator se vale das circunstâncias para apontar o punhal para o peito do agente, que,

2011), p. 75.

${ }^{21}$ Veja-se, a esse respeito, a tese de Carlos Orlandi Chagas, Novos defeitos do negócio jurídico. Tese de Doutorado. São Paulo: Faculdade de Direito, Universidade de São Paulo, 2014. 
“premido pela necessidade”, não pode agir diferentemente. ${ }^{22}$

Essa primeira imagem, do homem autônomo, reaparece nas excludentes de responsabilidade do art. 188 do Código Civil. Nos seus dois incisos, o código atual, que nisso repete precisamente o de 1916, menciona as hipóteses da "legítima defesa" e da “deterioração ou destruição da coisa alheia, a fim de remover perigo iminente". A primeira está para o fundado temor como a segunda para o dano iminente e considerável. Como na figura anterior, o agente não tem, aqui, como fazer de outra forma. Está à mercê de um fator externo (uma agressão, de que se defende legitimamente; a destruição de uma coisa, a fim de remover um perigo que é iminente, prestes a acontecer) que afasta dele a obrigação decorrente da responsabilidade extracontratual. A agressão sem fundamento (ilegítima) ou a destruição de coisa sem haver perigo, pelo contrário, obrigam-no, responsabilizam-no. E isso porque não havia fator externo que o compelisse ao contrário. Sua vontade, assim, não era, nesse caso, heterônoma, mas autônoma.

Uma ação, portanto, só “produz efeitos jurídicos”, isto é, enseja a proteção do Direito Privado e, por tal via, do Estado, se não resultar do medo. Vista em negativo, essa primeira condição nos faz distinguir um esboço inicial desse primeiro retrato. O sistema de obrigações que sua prática abriga supõe um indivíduo abstrato socialmente isolado, cujas ações não são causadas exclusivamente por sua vontade. Um indivíduo, assim, que só não será responsável pelas suas ações que não decorram de sua voluntariedade perfeitamente autônoma, que é a regra, ainda que desenhada em baixo-relevo. Se a responsabilidade é excluída pela presença de uma causa exterior que ocasiona a ação, des-

${ }^{22}$ A esse respeito, uma observação de Caio Mário da Silva Pereira é reveladora da oscilação, na melhor dogmática civilista, da natureza desse instituto que exclui a validade do negócio:

"O primeiro reparo que merece a remodelação do instituto está na observação de que se generalizou a qualquer contrato, deslocando-se, portanto, do campo restrito da compra e venda, para abranger qualquer outro tipo de convenção. Embora contrarie o princípio da autonomia da vontade, vem encontrando, todavia, a melhor acolhida na doutrina, principalmente por conservar a mesma inspiração de equidade que ditou as disposições originárias lá no direito romano, e apresentar-se como o meio técnico de reprimir no terreno do contrato a exploração usurária de um por outro contratante. Curiosamente observa-se, contudo, que a sua repercussão jurisprudencial não é tão profunda quanto o seu fundamento moral sugeriria. Não é a lesão puramente um vício do consentimento, de vez que o desfazimento do negócio não tem por fundamento uma desconformidade entre a vontade real e a vontade declarada. Difere a lesão do erro em que o agente no momento da declaração de vontade tem a consciência da realidade material das circunstâncias; não há nele o emprego de artifícios por parte de alguém que procure induzir o agente a realizar o negócio jurídico; difere da coação, em que falta o processo de intimidação sobre o ânimo do agente para compeli-lo ao negócio jurídico; e tanto se distancia da fraude que nem há mister salientar a diferença. Residindo, pois, a lesão na zona limítrofe dos vícios do consentimento, por aproveitar-se o beneficiário da distorção volitiva, para lograr um lucro patrimonial excessivo, é sem dúvida um defeito do negócio jurídico, embora diferente, na sua estrutura, dos até agora examinados, razão por que é chamado por alguns de vício excepcional." (Caio Mário da Silva Pe- 
pertando nele um fator psicológico que lhe rouba a autonomia, então, pelo avesso, só responde aquele cuja vontade é livre — definida esta "liberdade" dessa forma, pelo seu negativo.

Vale a pena, antes de prosseguirmos, confrontar esse quadro geral da dogmática jusprivatista com uma das hipóteses do trabalho escravo, previstas na Consolidação das Leis do Trabalho, no art. 462, § 2. : "É vedado à empresa que mantiver armazém para venda de mercadorias aos empregados ou serviços estimados a proporcionar-lhes prestações 'in natura' exercer qualquer coação ou induzimento no sentido de que os empregados se utilizem do armazém ou dos serviços". Veja-se que neste último caso o empregado é obrigado (pelas circunstâncias) a adquirir mercadorias ou serviços do empregador, sob pena de, isolado, sucumbir de fome. O empregador vale-se da circunstância para descontar do salário do empregado o que foi por ele adquirido (o caput do artigo veda ao empregador que este efetue "qualquer desconto nos salários do empregado, salvo quando este resultar de adiantamentos, de dispositivos de lei ou de contrato coletivo"). É uma hipótese típica de estado de perigo. Ainda na CLT encontra-se ao menos um outro caso de lesão: o art. 117, que declara nulo "qualquer contrato ou convenção que estipule remuneração inferior ao salário mínimo estabelecido na região, zona ou subzona, em que tiver de ser cumprido". Veja-se, porém, que enquanto no sistema jusprivatista os "vícios do consentimento" são anuláveis, ou seja, não obrigam o agente, mas exigem deste, para afastar-lhe a obrigação, a sentença judicial constitutiva negativa (inclusive na hipótese da responsabilidade civil, cujas excludentes terão de ser comprovadas), nos "novos subsistemas" (trabalhista, consumidor, etc.) a obrigação sequer nasce. Nos dois dispositivos há vedação legal expressa ao desconto ou ao pagamento a menor, e, no art. 117, expressa menção à nulidade ex vi legis ("Será nulo de pleno direito [...] qualquer contrato ou convenção que estipule remuneração inferior ao salário mínimo estabelecido na região, zona ou subzona, em que tiver de ser cumprido"), prescindindo do Poder Judiciário para sua declaração.

\section{A ignorância e o tempo do arrependimento}

Uma vontade só é autônoma, porém, se não houver algum fator que prive o agente de uma informação relevante. Dito de outra forma, se houver algum fator, subjetivo ou objetivo, que frustre o conhecimento pleno das circunstâncias relevantes, o agente não

reira, Instituições, vol. I, p. 456). 
será responsável, a obrigação não nascerá, a vontade não será realmente autônoma. Por privação deve-se entender que havia algum fator que impediu a "formação" da autonomia da vontade. Ignorando um elemento essencial para a deliberação (ignorância essa causada por fatores objetivos ou subjetivos inarredáveis, veremos a seguir) ou sendo incapaz, nas mesmas circunstâncias, de prever um resultado de sua ação, o agente não será responsabilizado. Sua vontade, nesses casos, é, ainda aqui, heterônoma, mas para compreender essa heteronomia é preciso que a análise da ação a observe pelo prisma da temporalidade, que permite a redução desta imagem àquela da coação.

Quando alguém, como Édipo, se sujeita à responsabilidade por aquilo que não sabia que estava fazendo, ou por cujas conseqüências (razoavelmente) seria incapaz de prever, temos uma figura de responsabilidade independentemente das condições subjetivas ou objetivas do agente - independentemente de sua vontade de querer aquilo que fazia com plena ciência de seus atos e conseqüências. A responsabilidade civil dita "objetiva" (e penal, nas restritas hipóteses em que é admissível, como na responsabilidade penal da pessoa jurídica ou na teoria da actio libera in causa), de nossos dias, tem pouca relação com essa figura histórica. As teorias jurídicas que pretendem explicá-la exibem, para sua presença, os elementos tradicionais da responsabilidade civil (ação ou omissão, nexo de causalidade, dano, ausência de excludentes), afastam o chamado "elemento subjetivo" (dolo ou culpa), e a partir daí inferem que se trata de uma hipótese de responsabilidade civil. Há casos em que sequer se mantêm elementos como a ação ou omissão, a exemplo da chamada "responsabilidade civil exacerbada" ou "pelo risco integral", diversa da teoria do "risco administrativo". O simples fato de que a dogmática desenvolva suas "teorias" - seus "retratos sociais" - recorrendo à noção de risco já demonstra o desajuste dessa relação jurídica no enquadramento na categoria de responsabilidade. Nasce daí a questão de saber por que tal desajuste permanece: se é devido à inércia interna à dogmática, ou se, com isso, produz-se um efeito, desenha-se um "retrato" conveniente que distorce e limita a sua abrangência e seu alcance. No contexto neokantiano, naturalmente, esse conceito não pode ter lugar, devendo ser excluído. ${ }^{23}$

\footnotetext{
${ }^{23}$ A esse respeito, novamente, Ernst Weinrib, The Idea of Private Law, op. cit., p. 173. Cabe destacar a analise de François Ewald das transformações da noção de responsabilidade civil, de subjetiva a objetiva. As primeiras três décadas que se seguem ao Code Napoléon constituem o auge da responsabilidade civil subjetiva, associada à idéia correlata, típica do liberalismo, de que cada um é senhor de seu destino e que os efeitos da liberdade não possuem desculpa. Os desafios da industrialização fazem com que a filosofia do risco e a instituição do seguro se tornem os instrumentos mais adequados para a administração social, para ele impropriamente denominado de "Estado de bem-estar social". Sua genealogia o revela como ligado a uma experiência particular do mal e à necessidade de se-
} 
Ora, na ausência de tais elementos, a dogmática foi obrigada a desenvolver "teorias" (do risco proveito, do risco criado, da atividade, etc.), ou seja, construções argumentativas que permitissem organizar (muito mais do que explicar) os condicionantes e os efeitos jurídicos desse conjunto de relações. Mas justamente essa crise teórica pode ser vista avaliada por um duplo ângulo. Pode revelar uma incongruência no próprio retrato que é construído a partir do foco na voluntariedade e sua autonomia, mas pode indicar também um equívoco no ponto de partida dessa tradição teórica que se obstinou, a partir de então, em tentar compreender como é possível uma responsabilidade civil, em última instância, "irresponsável”. O problema está menos na dificuldade em compreender a falha de origem e mais em entender o que motiva a obstinação do debate dentro de premissas que se evidenciam cada vez mais desajustadas — e isso quando a história da dogmática jurídica se constitui como uma história de escombros de teorias doutrinárias. $^{24}$

Voltemos. O núcleo desse fator, cuja análise só é completa pelo exame da temporalidade nele pressuposta, é o duplo par de figuras erro-dolo. O parentesco das duas figuras evidencia-se pela ausência, no agente, de uma informação relevante, seja esta privação resultante das circunstâncias (erro) ou de um ato de outra pessoa (dolo). É assim que o Código Civil define - e, contrariamente ao que sustentava a Teoria Geral do Direito mais difundida, tanto o atual quanto o de 1016 estão repletos de definições - o erro (art. 138) como aquele que "poderia ser percebido por pessoa de diligência normal, em face das circunstâncias do negócio”. Noutras palavras, o ato o negócio jurídico foi celebrado por uma pessoa de diligência normal, que examinou zelosamente suas circunstâncias. Ainda assim, uma informação relevante, que teria permitido a "formação" da autonomia da vontade, restou ignorada pelo agente.

Essa ignorância, diferentemente do dolo, não é produto da ação de outro sujeito, pelo que, por esse ângulo, o erro revela seu parentesco essencial com ele (e a simulação

gurança na forma do acidente. Mas, se o seguro privado ou social teve como efeito a multiplicação de casos de responsabilidade (objetiva, diga-se), e se é errado falar de um declínio da noção de responsabilidade (porque substituída pela objetiva), por outro lado a existência do Estado de bem-estar social seria a prova de que as sociedades contemporâneas teriam desistido de governar de acordo com o princípio da liberdade, substituindo-a pela de administração do risco (François Ewald. L'état providence. Paris, Grasset, 1986).

${ }^{24}$ Para a descrição desse fenômeno, ao qual retornaremos, veja-se Tércio Sampaio Ferraz Júnior, Função Social da Dogmática Jurídica (São Paulo: Max Limonad, 1998), p. 13. O texto de Carlos Eduardo Batalha da Silva e Costa, "A filosofia jurídica como saber metaideológico: anotações a partir da função social da dogmática jurídica no enfoque de Tércio Sampaio Ferraz Júnior". (In: José Rodrigo Rodriguez; Carlos Eduardo Batalha da Silva e Costa Barbosa e Samuel Rodrigues (Org.). 
e a fraude contra credores, entre outras tantas figuras assemelhadas). Posteriormente, constatada a falha informacional — daí o elemento tempo, pois o sujeito que sofre a coação sabe que sua vontade está viciada já no momento que pratica o ato, enquanto o sujeito em erro só o saberá depois, sua vontade lhe aparecendo, no momento inicial, perfeitamente livre, autônoma —, verifica que, na realidade, foi coagido pelas circunstâncias (exteriores) a agir da forma como o fez. A dissolução dessa aparência dá-se posteriormente, revela-se, ou melhor, desvela-se como um equívoco, cuja causa afastou a autonomia. Uma autonomia aparente, portanto, não real, e que se revela como tal retrospectivamente. É olhando para o passado que o agente percebe que não foi livre, que sua vontade estava capturada por um fator circunstancial que lhe impediu que visse a realidade. Se o coagido sabe desde sempre que sua vontade não era livre, o errôneo só o saberá depois. É o tempo do arrependimento.

Claro que o Código Civil estabelece restrições que, desde o Direito Romano, serviam para distinguir a falha informacional "relevante" daquela que não mereceria amparo. Essa relevância, que separa o erro substancial ou essencial do erro acidental, decorre do dever de diligência e zelo do agente com os próprios negócios de sua vida. Um erro substancial é aquele que diz respeito à "natureza do negócio, ao objeto principal da declaração, ou a alguma das qualidades a ele essenciais, à identidade ou à qualidade essencial da pessoa a quem se refira a declaração de vontade, desde que tenha influído nesta de modo relevante", ou ainda, "sendo de direito e não implicando recusa à aplicação da lei, for o motivo único ou principal do negócio jurídico”. Natureza jurídica do negócio (compra e venda, mas pretendia uma locação), objeto ou alguma de suas qualidades essenciais (características de uma máquina, que pretendia fabricasse determinado produto, mas fabrica outro), qualidade da pessoa (contratação de serviços a ser prestado por pessoa que, posteriormente, se descobre não possuir aquelas qualificações, sem que tenha havido dolo por omissão), etc. Em todos os casos, a autonomia da vontade não desaparece quando a falha diz respeito a uma informação não essencial, não substancial, meramente "acidental".

O retrato é o de um agente dotado de zelo e diligência. Digamos de outra maneira, se é possível anular o negócio jurídico, também é necessário que o agente prove que agiu de sorte a afastar a possibilidade de que decidisse de maneira afoita, sem buscar cercar-se de um quadro completo de informações do contexto de seu ato jurídico. Mais tar-

Nas fronteiras do formalismo. SãoPaulo: Saraiva, 2010), p. 153-185. 
de, ele terá de conviver com uma alteração radical, presente em contextos como aqueles do Código de Proteção e Defesa do Consumidor ou da Lei das Sociedades por Ações, que impõem a plenitude informacional à parte contrária, sob pena de nulidade do próprio negócio. Se esse retrato traça a imagem do homem diligente e zeloso, que procura o máximo de informação relevante para que possa decidir, determinando assim sua vontade, o desenvolvimento do direito irá entreabrir a hipótese em que a plenitude informacional não resulte de comportamento ativo do agente, mas da parte contrária. Num quadro assim, a autonomia da vontade, que devia resultar do próprio agente, passa a ser produzida, conduzindo à contradição de uma autonomia produto da heteronomia - uma liberdade não espontânea, mas "produzida". Sobrepor-se-á a ela, como veremos mais adiante, uma outra imagem.

A estrutura do dolo é semelhante àquela do erro, exceto que sua causa não é devida às circunstâncias, mas a comportamento, ativo ou passivo, de outrem. O art. 147 define o que é o dolo por omissão ("omissão dolosa"): "o silêncio intencional de uma das partes a respeito de fato ou qualidade que a outra parte haja ignorado, constitui omissão dolosa, provando-se que sem ela o negócio não se teria celebrado". Quando, ao contrário, não há silêncio, mas, por outro lado, apresentam-se informações à outra parte que não correspondem à realidade, tem-se o fenômeno do dolo. A exemplo do erro, este deve ser também substancial para que o negócio possa ser anulado: o negócio não teria sido realizado (a cláusula temporal reaparece) se a informação se mostrasse presente. A própria lesão admite a figura da ausência de informação plena para a formação da autonomia da vontade: o negócio não teria sido realizado se o agente contasse com suficiente "experiência” ("ou por inexperiência”, prevê o art. 157 do Código Civil).

O quadro, agora, está concluído. Retrata-se um indivíduo que não está sendo coagido, esteja ele ciente ou não disso. A vontade é livre, expressão de sua autonomia, quando o ato resulta da plena espontaneidade do agente, que é, na verdade, ausência de coação e plenitude de informação. Obriga-se toda vez que não há circunstância que afaste sua autonomia essencial. A autonomia aparece, assim, como resíduo, ou como o negativo da heteronomia: é autônomo aquele que não é (ou foi) obrigado a agir por nada além dele próprio. Obrigou-se "livremente". Guarde-se essa primeira imagem do indivíduo autônomo. É a primeira de outras camadas do quadro, que encontraremos a seguir. 


\section{Autonomia, espontaneidade, culpa e responsabilidade vinculante}

O senso comum aprova a idéia de que, se o agente agiu sem consciência plena de sua ação ou coagido por uma força externa, não deve ser responsabilizado por sua ação. Não pode ser obrigado a cumprir a palavra empenhada, não será responsabilizado pelo seu descumprimento, não haverá "responsabilidade contratual" a que se sujeite, não se vinculará aos efeitos indenizatórios do dano causado. Se agiu com a cautela devida, ou seja, a que se espera do "homem médio" em circunstâncias equivalentes, e se a condução dos acontecimentos — os efeitos reais de sua conduta — fugiram de seu controle por fatores exteriores a ele, não será responsabilizado pelas conseqüências, não haverá, aqui, "responsabilidade extracontratual". "Responsabilidade” é, assim, para utilizar a linguagem doutrinária mais conservadora, a característica de um ser dotado de personalidade jurídica conforme a qual se sujeita aos efeitos do descumprimento de um dever legal, especialmente do descumprimento de uma obrigação. Como "ninguém é obrigado ao impossível", se era impossível para o agente, nas circunstâncias concretas, conhecer uma informação relevante para sua decisão ou agir de modo diverso, não poderá ser responsabilizado pelos "efeitos jurídicos" de sua conduta. Portanto, será responsabilizado toda vez que sua conduta for efetivamente autônoma, isto é, espontânea. Continuemos mais um pouco na construção dessa abstração, desse primeiro retrato em muito desbotada do indivíduo.

Sabemos que a dogmática jurídica costuma distinguir ao menos dois tipos de culpa. Há a culpa como "gênero", que abrange duas "espécies": a "culpa em sentido estrito" e o dolo. Apesar das diversas espécies de dolo classificadas na dogmática do Direito Civil (bonus e malus, "estrito" e "amplo", "direto" e "indireto", “essencial" e "eventual”, etc.), todas têm em comum a presença da consciência da ação (“o que o sujeito está fazendo") e de seus efeitos (“o que daí resultará"). No dolo, a espontaneidade é plena: a causa da ação está plenamente presente no sujeito da ação. Não há nenhuma causa exterior que o mova a agir, e não há nenhum fator que o faça agir sem a plena consciência da ação. Agir dolosamente é agir sabendo e, mais ainda, não ser "agido". E, portanto, sujeitar-se plenamente aos efeitos jurídicos da responsabilidade.

A culpa, no sentido estrito da expressão, é um fenômeno jurídico muito mais meandroso. Na culpa, o agente "não quer o resultado danoso", mas ainda assim é responsabilizado. A dogmática freqüentemente se limita a referir-se a ela como uma "violação de um dever de cautela, cuidado, vigilância”, etc. Ora, enquanto no dolo o agente quer o resultado, ou não se importa com ele, o que significa que, em ambos os casos, está 
consciente dele ou de seu risco, na culpa há sempre alguma espécie de inconsciência. A dogmática tem distinguido os conceitos de "culpa consciente" e "culpa inconsciente". Conceitualmente, porém, toda culpa envolve um elemento de inconsciência, já que, do contrário, seria indistinguível do dolo. Mas se a culpa envolve inconsciência, como é possível que essa espécie de erro enseje a responsabilidade do agente? Como alguém que não sabe o que está fazendo o que se sucederá a partir daquilo que está fazendo pode responder pelos "resultados de sua ação"?

A linha tênue entre o erro e a culpa sempre foi traçada considerando um "dever de cautela", conhecido do agente e por ele descumprido. Uma regra, seja técnica, seja vagamente empírica, era ou "devia ser" de conhecimento do agente. Assim, quanto a isto, não há erro, exceto se ele puder comprovar que ignorava a norma e não tinha o dever de conhecê-la. O padrão, a "pedra de toque" que permite, então, aferir a presença ou não de responsabilidade na ação é a consciência, melhor dizendo, a "ciência" pelo agente da norma que estabelecia um procedimento para agir. Se a conhecia (e, se não a conhecia, tinha o dever de conhecê-la) e não a seguiu ao agir, pouco importa se não estava ciente dos efeitos de sua conduta. Houve descumprimento de um dever, digamos, um "dolo" contra uma norma, e, por conseguinte, responsabilidade.

A resposta poderia parecer, apesar de engenhosa, simples e satisfatória, não fosse o fato de que na culpa o descumprimento do dever associa-se à crença, pelo agente, de que seu descumprimento é possível porque o efeito danoso não irá ocorrer. O agente crê, fundamentadamente, que pode deixar de cumprir o que o cânone (empírico ou técnico) impõe, porque está certo que o efeito não advirá como conseqüência, e nisso erra. Mas a responsabilidade por culpa despreza essa crença, por mais fundamentada que esteja: o agente é responsável não porque não previu o resultado (que possivelmente não poderia mesmo antecipar), mas porque se voltou contra a norma, “ferindo-a". Na prática, porém, as fronteiras são em regra difíceis de estabelecer, especialmente quando se está diante da culpa decorrente do descumprimento do que estamos chamando de uma regra "empírica" de cautela, ou seja, aquele cânone aberto de regras nascidas da experiência de uma pessoa, viscosamente subjetivas e imprecisas. Se já é difícil identificar a culpa quando um médico ou um piloto de aeronave descumprem as regras que a técnica lhes impõe, quando estamos diante de um "homem médio" e dos elementos indefinidos do contexto prático concreto da ação, a identificação da culpa (e de seu grau) é nebulosa, controversa, quando não impossível. O mesmo vale, obviamente, para o erro "escusável" e a "essencialidade" ou "acidentalidade" do "erro essencial".

Como quer que seja, a espontaneidade da ação é ainda o fundamento da responsa- 
bilidade por culpa, sendo mais uma de suas contraprovas. A primeira condição da responsabilidade era que o princípio da ação não estivesse fora do agente, mas nele mesmo (não fosse coagido, forçado; não fosse "agido", mas agisse). A segunda, que nenhum elemento contextual "essencial" impedisse que previsse as conseqüências de sua conduta. O resultado negativo deste último elemento é que, ainda que as conseqüências sejam imprevisíveis, há normas expressas ou genéricas que impõem cânones de cautela que não devem ser descumpridos, sob pena de o agente ser responsabilizado pelos seus efeitos. Portanto, se conhecia tal "canônica", nascida das "máximas da experiência", como a elas se refere o Código de Processo Civil de 1974, e se não tinha como não conhecêla, pouco importa que ignore o possível resultado. Um resultado desfavorável que advenha não implicará culpa, "afastando o nexo de causalidade", como se refere a dogmática civilista, somente se o agente cumpriu com o dever de cautela - não agiu com culpa. Novamente, o desenho da abstração pelo recurso à negativa, como que em baixo-relevo é, como se vê, essencial.

A espontaneidade da ação, descrita negativamente, circunscreve assim o domínio da autonomia da vontade. Uma ação totalmente decorrente de um querer que ela seja como é, com suas plenas conseqüências, é aquela em que o agente age na sua plena espontaneidade, sem que nenhuma causalidade exterior lhe imponha um curso ou o limite. Daí que as "relações jurídicas" que nascem da espontaneidade plena sejam "vinculantes”, pois não há, por assim dizer, "culpado", “álibi” que o agente possa invocar para afastar de si os efeitos da responsabilidade. Era ele, e apenas ele, o agente da ação (anotese que o próprio Código Civil permite a "compensação de culpas" e a redução proporcional da indenização à responsabilidade).

Formalmente, essas são as partículas elementares que constroem a "Teoria Geral das Obrigações", o átomo de que se compõem, por sua vez, as moléculas que constituiriam a totalidade das relações jurídicas que organizam o sistema do Direito Privado. Elas são encontradas, é claro, em primeiro lugar na Teoria Geral das Obrigações do Direito Civil. Avançam a partir daí para a teoria dos contratos, para a responsabilidade civil, reaparecem no Direito de Empresa clássico, e alcançam, como os exércitos de Alexandre, o limiar (por ora, ainda não o conteúdo) dos confins dos "institutos jurídicos" da propriedade e do enriquecimento sem causa. Os efeitos de um contrato que constitui uma sociedade são presididos por essas características do núcleo atômico da Teoria das Obrigações. Os efeitos da propriedade e da posse, desnecessário dizê-lo, sujeitam-se à mesma disciplina: é protegida a posse "de boa-fé", ou seja, em que o possuidor "desconhecia" seu vício, deixando de sê-lo a partir do momento em que passa a estar ciente de- 
le; o proprietário é responsável pela indenização quando descumpre os deveres de cautela impostos pela função social da propriedade, etc.

\section{A universalidade da norma resultante da vontade autônoma}

A conduta não-livre, no sentido de decorrer de alguma espécie de coação (resultante de um fator qualquer que a determinou externamente ao próprio ato da vontade), afasta a responsabilidade. Condutas plenamente livres a produzem. Até aqui, porém, não adiantamos nada quanto ao próprio conteúdo do Direito Privado. Vimos que há uma estrutura subjetiva que compõe o núcleo da Teoria das Obrigações e que circunscreve um espaço de plena espontaneidade do agente, plena "autonomia da vontade", assim caracterizada como aquilo que não é a heteronomia, que se opõe a alguma espécie de indução, qualquer que seja ela. Essa noção de liberdade como plena "autonomia da vontade" como o avesso da "heteronomia" pode, porém, ser levada adiante para servir de contrapiso sobre o qual se assentaria o próprio conteúdo dos comandos do Direito Privado. Se isso for possível, o Direito Privado poderia ser compreendido como a manifestação jurídica de uma teoria ética da liberdade da vontade e da autonomia individual.

O programa do neokantismo jurídico, portanto, agora, é reconduzir os principais “institutos jurídicos” como a dogmática costuma chamá-los - aqueles átomos que considera como os mais fundamentais, ou os mais freqüentes, na formação das moléculas que compõem o Direito Privado (como a responsabilidade, o contrato, a propriedade, etc.) - possam ter seu conjunto mais essencial de relações traduzidas numa "teoria ética”. E pouco importaria ir além de certo nível no debate dessa teoria. Afinal, se o direito é aplicável, se existe sob a forma que o conhecemos, isso seria mais uma prova da adequação dessa teoria. Que o direito possa ser diferente seria irrelevante: postule-se essa ética e o direito passa a encontrar um fundamento para além do formalismo, do decisionismo ou de interpretações históricas. Sem medo do jargão, digamos que ela recolherá as "condições de possibilidade do Direito Privado".

O projeto tem longa história e não se trata aqui de remontar aos detalhes de sua primeira formulação na Fundamentação da Metafísica dos Costumes ou, a seguir, na Doutrina do Direito de Kant, de 1797, e que constitui a primeira parte de outra obra sua, a Metafísica dos Costumes. Já tivemos oportunidade de sermos a ela apresentados anteriormente. Sua real influência sobre a dogmática jurídica franco-alemã no século XIX é controversa e difícil de medir. Que tenha havido uma "influência" de Kant sobre aquela, seja lá o que for que entendamos por isso (in-fluentia: "lançar eflúvios para dentro de 
algo", termo que remonta ao menos à época da magia natural renascentista), decorre muito da velha ilusão platônica de que o filósofo poderia interferir, ex machina, no curso da política e do direito. E decorre também da freqüente estratégia autolegitimatória da própria disciplina universitária, que se justifica perante as demais disciplinas acadêmicas respondendo que é ela a responsável última pelo conteúdo da dogmática, pelo sistema de normas e pela própria jurisprudência, pelo que um lugar deve continuar a serlhe assegurado no meio acadêmico. Que se possa então concluir pela "influência" da ética kantiana sobre a pandectística ou, de modo mais geral, sobre a dogmática privatística do século XIX, sem que mediações precisas e evidências históricas fortes, amplas e concretas sejam apresentadas, é uma tese frouxa o suficiente para lançar na irrelevância habitual o estudo da real relação histórica entre esses dois terrenos. Mais sensato seria, talvez, considerar que tanto Kant quanto a dogmática daquele período se debruçaram sobre a mesma matéria ideológica para construir o conceito de autonomia da vontade, cada um com suas preocupações. Se, após isso, notamos uma homologia entre Kant e a dogmática liberal do século XIX, o resultado é menos decorrente de uma influência recíproca do que da estrutura do objeto - a fantasmagoria do indivíduo liberal abstrato — sobre o qual, com métodos diversos, os dois se debruçaram.

O que vale a pena, porém, retomando o fio da meada metodológico, é valer-se do atual projeto que pretende organizar o campo dos principais institutos do Direito Privado num sistema consistente a partir dos fundamentos da ética kantiana para, a partir daí, avançar mais na emersão de um dos retratos possíveis do indivíduo abstrato que a prática jurídica nesse campo do direito tece num sistema de narrativas e pressupõe. A ser assim, o mergulho do escafandrista estará devidamente protegido, e o mergulhador não correrá o risco da contaminação. A teoria, apresentada por aqueles que pretendem fundamentar o Direito Privado na recuperação da ética kantiana, servirá antes como plataforma que nos permitirá um ângulo de observação para preencher a épura de um dos retratos do Direito Privado: o do homem autônomo.

Até agora, só é livre quem é autônomo, só é responsável quem é livre, e só é livre quem é espontâneo, ou seja, cuja vontade é determinada apenas por si própria. Tal conjunto de fronteiras daria origem a uma fundamentação ética do Direito Privado se puder ser traduzida numa distinção kantiana entre "agir por um comando da razão" e "agir em obediência a uma inclinação". Essa bem conhecida cisão da subjetividade — que, aliás, Adorno e Horkheimer na Dialética do Esclarecimento não deixarão notar e denunciar — parte do princípio de que a inclinação, por dirigir-se a um objeto particular e não poder sujeitar-se a um comando da vontade, sujeita a vontade, que se torna, por conse- 
guinte, não-livre. O princípio é clássico e remonta ao Tratado da Alma de Aristóteles, se não mesmo à República de Platão: o apetite é por princípio irracional, não admite diálogo, não pode ser objeto de "elaboração", como mais tarde dirá a psicanálise, rompendo com mais esse postulado da teoria psicológica clássica. Não há como moldar a inclinação que busca fugir da dor e buscar o prazer, no sentido mais amplo desses dois termos. A vontade pode apenas render-se à inclinação, pelo que será por princípio heterônoma, encontrando seu nomos fora de si própria e rebaixar-se ao nível da animalidade humana, ou buscar em si própria a norma de sua conduta, ou seja, autonomamente. A autonomia, agora, reencontra dentro de si o predador que a acuava: as inclinações, como os pássaros-sereias da Odisséia, devem ser reprimidas, recalcadas, para que a vontade possa dominar a si própria e prevalecer como senhora absoluta. Com a palavra, agora, a filosofia do Direito Privado neokantiana:

Aqui, intencionalidade, como uma causalidade de conceitos, espontânea e livremente inicia uma série de efeitos: o ser dotado de propósito - ainda que afligido pela inclinação, que lhe pode sugerir um conteúdo para a ação — não é determinado pela inclinação e não está, portanto, sob o domínio coercitivo de qualquer representação ou objeto de desejo particulares. Uma vez que este modo de intencionalidade é inicialmente concebido por meio de seu contraste com determinação sensível e não através de qualquer traço positivo do dela própria, Kant a caracteriza como liberdade em seu aspecto negativo. ${ }^{25}$

Para que possa haver efetivamente "liberdade individual", a vontade não pode ser comandada por absolutamente nada além de si própria, o que inclui, obviamente, as inclinações. $^{26}$

Toda inclinação, por princípio, tende para a satisfação buscando alcançar um bem

${ }^{25}$ Ernst Weinrib, The Idea of Private Law, op. cit., p. 114. O processo argumentativo kantiano na Fundamentação da Metafísica dos Costumes é algo para o qual Weinrib chama a atenção e merece, de fato, que atentemos para ele: a transição de uma definição negativa da liberdade para uma positiva, que nasce do resíduo encontrado, a saber, da autonomia da vontade. (Em tempo: não se deve confundir a Fundamentação da Metafísica dos Costumes, obra de 1785, com a Metafísica dos Costumes, trabalho posterior e de fôlego muito maior, publicada doze anos depois, em 1797, e composta de duas partes, a primeira sendo da Doutrina do Direito e a segunda, a Doutrina da Virtude. É nela que Kant expõe sua teoria do direito. Na Fundamentação, porém, Kant expõe os princípios gerais de um sistema ético; é nela que Kant burila o conceito de autonomia da vontade retomado pelo neokantismo que nos interessa aqui).

${ }^{26}$ Difícil não perceber o caráter abstrato da subjetividade assim construída, uma objeção da qual Weinrib não escapa e está plenamente consciente: "De acordo com Kant, o livre-arbítrio é a capacidade de abstrair de qualquer objeto particular de desejo. A ação, assim concebida, pressupõe um eu vazio $e$ isolado que pode permanecer recuado do contexto em que se encontra e refletir sobre como ele pode exercer a sua capacidade de agir. Uma vez que é caracterizado por uma capacidade de escolha que é anterior a qualquer, esse eu parece ser histórica e socialmente desenraizado." (Weinrib, The Idea of Private Law, op. cit., p. 216, grifei). Eis o ponto: ou Weinrib não se dá conta, ou não quer extrair as conseqüências últimas desse "desenraizamento histórico" do indivíduo abstrato em que ele aposta e que ele reconstrói. 
particular ao agente. Acidentalmente pode até produzir um bem geral, mas como o próprio termo já indica, tende a um objeto que seja um bem para aquele que a ele se inclina. A "máxima" de uma ação dessa espécie — ou seja, o resultado da depuração de todos seus elementos acidentais, sua estrutura típica e essencial - tem a estrutura lógica de um “imperativo hipotético". Imperativos hipotéticos são proposições em que o verbo “dever” aparece (daí serem imperativos), mas que também condicionam a obtenção de um resultado à realização de uma determinada ação ("se alguém pretende obter um resultado A, então deve fazer B"). Imperativos hipotéticos, portanto, relacionam fins particulares a um agente a meios igualmente particulares. Não podem, por conseguinte, ser universalizados, pois não se desprendem do contexto prático e do agente que titular daquelas inclinações particulares.

O passo argumentativo seguinte é evidente e decorre da mera combinação da definição de liberdade como autonomia, e, portanto, com a de resistência a ceder às inclinações, de onde decorre a idéia de que a vontade deve dar a si própria sua norma, com a estrutura lógica da máxima de uma ação comandada por uma inclinação:

A vontade é uma espécie de causalidade dos seres vivos, enquanto racionais, e liberdade seria a propriedade desta causalidade, pela qual ela pode ser eficiente, independentemente de causas estranhas que a determinem; assim como necessidade natural é a propriedade da causalidade de todos os seres irracionais de serem determinados à atividade pela influência de causas estranhas. A definição da liberdade que acabamos de propor é negativa e, portanto, infecunda para conhecer a sua essência; mas dela decorre um conceito positivo desta mesma liberdade que é tanto mais rico e fecundo. Como o conceito de uma causalidade traz consigo o de leis segundo as quais, por meio de uma coisa a que chamamos causa, tem de ser posta outra coisa que se chama efeito, assim liberdade, se bem que não seja uma propriedade da vontade segundo leis naturais, não é por isso desprovida de lei, mas tem antes de ser uma causalidade segundo leis imutáveis, ainda que de uma espécie particular; pois de outro modo uma vontade livre seria um absurdo. A necessidade natural era uma heteronomia das causas eficientes; pois todo o efeito era só possível segundo a lei de que alguma outra coisa determinasse à causalidade a causa eficiente; que outra coisa pode ser, pois, a liberdade da vontade senão autonomia, i. é, a propriedade da vontade de ser lei para si mesma? Mas a proposição: "A vontade é, em todas as ações, uma lei para si mesma", caracteriza apenas o princípio de não agir segundo nenhuma outra máxima que não seja aquela que possa ter-se a si mesma por objeto como lei universal. Isto, porém, é precisamente a fórmula do imperativo categórico e o princípio da moralidade; assim, pois, vontade livre e vontade submetida a leis morais são uma e a mesma coisa. ${ }^{27}$

Se a ação livre é aquela que não é comandada por uma inclinação (o que afastaria a autonomia), e esta assume a forma de um imperativo hipotético, a máxima de uma ação em que a vontade dá a si própria a norma deve assumir a forma de um "imperativo cate-

${ }^{27}$ Kant, Fundamentação da Metafísica dos Costumes. Trad. Paulo Quintela. Lisboa: Edições 70, 2011, p. 93. 
górico", ou seja, não sujeito a uma condição. O primeiro teste (que corresponderá, na Crítica da Razão Prática, à primeira formulação do imperativo categórico) consiste, portanto, em verificar se a máxima da ação chega a desprender-se do contexto prático particular (circunstâncias, mais características e estado do agente), pois, do contrário, o imperativo será hipotético, e, nos termos kantianos, conduzirá a vontade a entrar em contradição consigo mesma (pretende a autonomia, mas encontra a heteronomia). Se a máxima for universalizável, ou seja, se puder ser ao mesmo tempo máxima de qualquer contexto prático para qualquer agente, não dando origem a nenhuma contradição ou irracionalidade, isso significa que perdeu a particularidade que a mantinha atracada aos interesses e inclinações de um sujeito particular. Portanto, como tal, é um comando incondicionado que preside a vontade e a liberta da determinação exterior a ela, garantindo-lhe a autonomia. Chegamos à formulação (a primeira) do imperativo categórico da Fundamentação da Metafísica dos Costumes.

O exemplo que ilustra o quadro, seguramente muito esquemático, acima apresentado é o do direito à mentira e o correspondente dever incondicionado de sempre dizer, em qualquer circunstância, a verdade, e que abriu uma polêmica entre Benjamin Constant, Kant e John Stuart Mill. ${ }^{28}$ Façamos uma pausa aqui em nossa jornada e nos detenhamos sobre ele alguns instantes.

O exemplo é mais importante para uma "filosofia do Direito Privado" do que parece à primeira vista, já que, ao perseguirmos suas conseqüências últimas, nos depararemos com nada menos do que o dever de cumprir promessas, ou seja, com o dever de cumprir os termos de um contrato. O teste apresentado por Kant conduz a Metafísica dos Costumes a concluir que, se houvesse direito de mentir (conforme certas condições), a própria noção de promessa se esfacelaria. Uma promessa supõe o compromisso sincero das partes. Uma promessa que admitisse a possibilidade da mentira conteria uma contradição lógica em sua própria definição. Seria totalmente inútil declarar minha vontade relativamente a minhas ações futuras, afirmará Kant, a outros indivíduos, pois eles simplesmente não acreditariam e, reversamente, se acreditassem, eu próprio não poderia acreditar em suas palavras. Levada ao limite, a argumentação compromete, co-

\footnotetext{
${ }^{28}$ Benjamin Constant defende o direito de mentir em situações extremas. Kant, no célebre "Sobre um pretenso direito de mentir por amor aos homens", responderá com o rigorismo conhecido. Mill, posteriormente, retomará a resposta de B. Constant. A esse respeito, vale a pena o precioso texto de Bento Prado Júnior, "Não dizer a verdade equivale a mentir?" (Discurso, n. 15, 1983). O texto de Kant foi publicado em Os filósofos e a mentira (Fernando Rey Puente, org. Belo Horizonte, Editora UFMG; Departamento de Filosofia - FAFICH/UFMG, 2002). A crítica de Mill a Kant está em $O U$ -
} 
mo se vê, a própria linguagem (os analíticos poderão chamá-la de “contradição pragmática" um século e meio depois), que se apoiaria num contrato tácito pressupondo, entre outras coisas, que cada um atribua à linguagem os mesmos significados compreendidos pelo outro. Portanto, tal máxima constitui um imperativo hipotético, demonstra antes que o agente se está curvando perante suas inclinações e, assim, ao não resistir a elas, perdeu a efetiva liberdade.

Claro que essa construção, na sua radicalidade, sempre chamou a atenção dos críticos. Benjamin Constant objetou a Kant que só tem dever de dizer a verdade aquele que se encontra perante alguém que tem o direito de ouvi-la. Com essa perífrase, Benjamin Constant pretendia evitar o desconforto, bastante evidente para um liberal francês que assistiu aos episódios da Revolução, de uma verdade que é um "mal maior" (os malfeitores que batem à porta à procura de um inocente: pode-se mentir para salvá-lo?). Mas é claro que o circunlóquio só é possível se a própria base da teoria for implodida: a existência possível de imperativos hipotéticos com conteúdo moral. Nesse caso, é necessário expandir a correção para todos os domínios, especialmente a das promessas, e arcar com as conseqüências últimas da sugestão teórica: devo cumpri-las (dentre elas, os contratos) apenas para quem tem direito de que sejam cumpridas? Que dizer da proteção legal mais ampla à propriedade? $\mathrm{O}$ contrato de trabalho admite o descumprimento pelo empregado? Há nele algo de dolo ou mentira? A solução, sabemos bem, não se encontra na ética, mas na doutrina da religião kantiana, onde o postulado de um reino dos fins onde felicidade e dever moral se encontrariam é condição da própria ética. A certeza de que, se for possível apagar a contradição, isso só se dará na vida após a morte, reflete numa abstração a própria contradição na matéria social que lhe serve de base.

Retornemos a jornada. Os principais institutos jurídicos, então, devem agora submeter-se a esse teste. Não é difícil imaginar como a disciplina jurídica clássica da propriedade, da responsabilidade civil e dos contratos emergirá, com detalhes cada vez maiores, a partir desse quadro inicial. A primeira parte da Metafísica dos Costumes, então, poderá a partir de agora "deduzir transcendentalmente" esses principais institutos. As três conhecidas máximas de Ulpiano ("viver honestamente", "não prejudicar ninguém”, “dar a cada um o que lhe é seu”), que presidem especificamente os núcleos da responsabilidade civil e dos contratos, serão traduzidos nessa máxima. O teste, previsto na Metafísica dos Costumes para examinar se uma ação está conforme ao direito e, as-

tilitarismo (Trad. e introd. de Pedro Galvão. Porto: Porto Editora 2005). 
sim, deduzir as principais relações jurídicas que se irradiam dos institutos jurídicos fundamentais do Direito Privado, decorrerá da própria liberdade do agente como fundamento último. Se a máxima da ação não interfere com a liberdade alheia, então ela está conforme o direito:

"É correta toda ação que permite, ou cuja máxima permite, à liberdade do arbítrio de cada um coexistir com a liberdade de todos segundo uma lei universal etc." Por conseguinte, se minha ação, ou em geral meu estado, pode coexistir com a liberdade de cada um segundo uma lei universal, então age injustamente comigo aquele que me impede disso, pois este impedimento (esta resistência) não pode coexistir com a liberdade segundo leis universais. Segue-se disso, também, que não se pode exigir que esse princípio de todas as máximas seja por sua vez minha máxima, isto é, que eu o torne máxima de minha ação, pois cada um pode ser livre mesmo que sua liberdade me seja totalmente indiferente ou que eu deseje de coração causar-lhe prejuízo, contanto que não a prejudique por meio de minha ação externa. Tomar como máxima o agir conforme ao direito é uma exigência que a ética me faz. Alei universal do direito - "aja externamente de tal modo que o uso livre de seu arbítrio possa coexistir com a liberdade de cada um segundo uma lei universal" -é realmente, portanto, uma lei que me impõe uma obrigação, mas que não espera de modo algum,e menos ainda exige, que eu mesmo deva limitar totalmente minha liberdade àquelas condições em nome dessa obrigação. A razão diz apenas que o arbítrio é limitado em sua idéia e também que tem de ser limitado por outro, e isso ela diz como um postulado que não é suscetível de prova ulterior alguma. -Quando o propósito não é ensinar a virtude, mas apenas expor o que é correto, então não se precisa, e não se deve, apresentar aquela lei do direito como móbil da ação. ${ }^{29}$

O Direito Privado, portanto, é um mapa que demarca as divisas entre as ações que interferem ou não com a liberdade (negativa, sempre, apesar de observada em baixorelevo) alheia. O teste da universalização da máxima da experiência corresponde ao estabelecimento de um sistema de balanços entre os limites da liberdade (novamente: negativa) de outros indivíduos. A autonomia de outro indivíduo depende, portanto, da possibilidade de universalização da máxima da minha desse indivíduo despojado de tudo, exceto de sua vontade. Mas isso corresponderia a um comando da razão que, como tal, só pode ser indiferente às inclinações individuais. Deste ângulo ao menos, os interesses, desde que racionais, seriam reciprocamente conciliáveis e o sistema do Direito Privado seria o "Reino da Liberdade".

\section{De volta para o futuro: o formalismo neokantiano}

Os contornos da teoria kantiana do direito e sua "fundamentação" do Direito Privado traçada sucintamente acima parecem não permitir algo mais do que um exame his-

${ }^{29}$ Immanuel Kant. Metafísica dos costumes. Tradução de Clélia Aparecida Martins. Petrópolis, Vozes, 2013, p. 30 (Primeira Parte, "Introdução à Doutrina do Direito", parágrafo C). 
toriográfico de um capítulo da filosofia clássica alemã do século XIX. O paradoxo ou antes a perplexidade - que daí surge está no fato de que algumas "análises morais" do direito na atualidade se tenham "inspirado" nela para promover seu aggiornamento. Ilustremos com um exemplo cuja análise, talvez pela pretensa profundidade, nos abrirá um caminho alternativo e indireto ao objetivo de nosso trabalho que é trazer à superfície um dos retratos que coordena o Direito Privado na sua prática. Tomemos uma obra que deu origem a um festival de respostas, “debates" e congêneres, prática típica do ambiente universitário estadunidense, "civilização do paper" de que falava Merleau-Ponty: o livro a que vimos fazendo menção de Ernst Weinrib, The Idea of Private Law, o principal "proponente" desse retorno a Kant na filosofia do Direito Privado.

Cuida-se de um trabalho em que o autor pretende a rejeição da tese de que o Direito Privado não possua uma "moralidade" própria, opondo-se tanto ao positivismo jurídico tradicional (cujas teses fundamentais abrangem, como sabemos, entre outras, a da separação radical entre direito e moralidade, ponto que trataremos com mais cuidado ao final deste trabalho), quanto às assim denominadas "análises econômicas do direito". O Direito Privado ganha o estatuto de um território autônomo perante outros "ramos" do direito (possui uma especificidade própria que decorre de sua moralidade específica), ao mesmo tempo em que o método de seu estudo e sua prática rejeitam qualquer análise funcionalista que o examine a partir de objetivos externos, funcionalmente considerados, que possam ser justificados independentemente de sua própria moralidade interna.

O núcleo argumentativo da recuperação neokantiana de Weinrib está na teoria da responsabilidade civil, que ele considera o núcleo em torno do qual se organizam os institutos do Direito Privado. Afastando-se da família positivista, Weinrib irá ver o Direito Privado não como um sistema de normas, mas uma prática, ou seja, um "empreendimento jurídico" no qual uma "razão pública coerente" elabora as normas implícitas na interação entre as partes. E é justamente essa "moralidade interna" que ele pretende descobrir no interior da prática do Direito Privado, alinhavada pelo núcleo fundamental da responsabilidade civil, que permite não só compreender por que é um sistema dotado de unidade, mas como é possível que seja dotado de independência diante de outros ramos. Dotado, portanto, de uma "moralidade interna", o sistema do Direito Privado encerra-se em si próprio e rejeita qualquer explicação que recorra ao que ele denomina de "análises funcionalistas", a primeira das quais, é claro, é o conjunto daquelas que recorrem à microeconomia para justificar as normas jusprivatísticas.

Essa moralidade interna não está presente apenas no conjunto de normas, repitase, mas antes é produto de uma "atividade coerente dos tribunais", que conforme essa 
bússola, encontraria sistematicamente o norte de suas decisões. O sistema é in fieri, está sendo feito, tecido constantemente a cada nova decisão. A calibragem do sistema é dada justamente por essa moralidade interna que serve de padrão para aferir a cada momento o rumo tomado e se o tecido continua a ser urdido coerentemente. Daí sua conclusão: os tribunais não são nem organismos que estão e devem estar a serviço de uma "racionalidade externa" (ou seja, de padrões de eficiência microeconômica ou pela "publicização" do Direito Privado), nem instituições políticas cujo comportamento seria explicável politicamente (pela sociologia do Poder Judiciário, pela ciência política, pela história). São “instituições públicas" em que se constrói uma "racionalidade pública" nas decisões que tomam no Direito Privado, interpretadas na linha das teorias da "razão pública". Contra uma concepção instrumental do Direito Privado, Weinrib opõe, portanto, um "formalismo" (cuidado: no sentido kantiano da palavra, não no sentido que o termo tomou ao longo da história da filosofia do direito no século XX — não é sinônimo de "normativismo" ou "positivismo jurídico"!) que lhe assegura seu crescimento constante dentro do próprio território, delimitado e demarcado ao longo de sua extensão por fortalezas que impedem o ataque de colonizadores.

A proposta de tomar como núcleo do Direito Privado o instituto da responsabilidade civil à primeira vista é sedutora como o canto das sereias. Afinal, a responsabilidade civil foi vista, desde os esforços da Pandectística no século XIX, como um gênero, de que são espécies a responsabilidade civil extracontratual e a responsabilidade civil contratual. ${ }^{30}$ Assim, o gênero já abrangeria as espécies, e se for possível encontrar no gênero os princípios fundamentais que as coordenam, então seria possível a partir daí organizar a totalidade do Direito Privado, remetendo cada um de seus institutos e cada particularidade ao ponto focal supremo da responsabilidade civil. A operação é feita por Weinrib recorrendo a uma leitura da teoria da justiça comutativa de Aristóteles e Tomás de Aquino. Na comutatividade, a mesma moeda que apresenta a face "dar a cada um o que lhe é devido" (princípio da teoria dos contratos) tem como verso o dever de "não lesar ninguém" (princípio da responsabilidade civil). Isso porque o descumprimento do avençado no contrato determina a responsabilidade pelo dano decorrente da quebra da legítima expectativa. A diferença entre ambos estaria na existência ou não de um acordo

\footnotetext{
${ }^{30} \mathrm{O}$ debate sobre a possibilidade de uma teoria unificada da responsabilidade civil remonta ao século XIX. Weinrib, no entanto, sustentará, obviamente, um conceito unitário de responsabilidade, que abrange as duas espécies. A esse respeito, veja-se mais uma vez Weinrib, The Idea of Private Law, op. cit., p. 19-21.
} 
prévio de vontades, irrelevante, ao menos neste primeiro patamar, mesmo porque é suficiente descermos um degrau para sabermos que já no século XIX a dogmática jurídica se deu conta de que a redução é impossível.

E isso porque, num caso, há manifestação prévia de vontade; no outro, não. Num caso, há descumprimento de um acordo; no outro, não. Num caso a responsabilidade exige ou a prévia previsão contratual para constituir em mora o devedor, ou manifestação de vontade expressa do credor; no outro, o inadimplemento nasce com o próprio dano. Num caso a contagem de juros moratórios, decorrente do dano que prossegue no tempo, se inicia da constituição em mora pela manifestação de vontade, prévia (contratual) ou posterior ao descumprimento do contrato; no outro, já se inicia com o próprio dano. E assim por diante. Tais diferenças não são características específicas do Direito Privado brasileiro. Não só remontam à recepção do Direito Romano pela Escolástica Tardia no século XVII, que estará na base tanto do direito latino, mas também, a partir do século XIX, das doutrinas que sistematizarão o direito da assim denominada "tradição da common law”. Lá como cá, as características são gerais e comuns. Os detalhes que especificam cada sistema jurídico nacional só se encontram em patamares mais baixos. É preciso descer vários e vários degraus para encontrar especificidades que distinguem um de outro, como prazos prescricionais ou meios legais de constituição em mora. ${ }^{31}$ Seja como for, a conexão “dano-dever de indenizar" está presente em ambas, o que tornaria legítima a pergunta por qual seria seu fundamento último, dado que, afinal, não deve ser encarado como mero conjunto de meios a serviço da realização de fins que lhe são exteriores.

\footnotetext{
${ }^{31}$ Há quem sustente que os sistemas jurídicos jusprivatísticos internacionais atingiram a convergências de seus principais institutos já no século XIX. Para James Gordley, a unificação, no terreno do Direito Privado de tradição romanística, foi obtida com o emprego de categorias buriladas na Escolástica tardia dos séculos XVI e XVII: um misto do Direito Romano receptum e da teoria da justiça aristotélica e tomista. Tais autores teriam desenvolvido as categorias que conduziram, mais tarde, tanto a Escola Histórica quanto a Pandectística à formulação das categorias mais gerais e abstratas que serviriam de pilastras a esse ramo do direito (personalidade, capacidade, obrigação, contrato, propriedade, posse, responsabilidade, ato ilícito, enriquecimento sem causa). No século XIX, ainda segundo Gordley, o direito comum anglo-saxão (a família do Common Law), essencialmente empírico e muito pouco sistemático, teria importado do continente essa trama categorial e organizado seu próprio direito nessa estrutura. A forma como ele é ensinado e aplicado, nos dias de hoje, remontaria a essa transposição de resultados de outra tradição jurídica (romanística) para seu próprio bojo. Daí que a diferença entre os sistemas seria mais de detalhe ou de conteúdo do que de forma ou de princípio (prazos prescricionais, idades, direito de família ou sucessório, etc.). E o apogeu ter-se-ia dado com a edição pela China de um Código Civil de moldes romanísticos em 1987, rompendo com a tradição jurídica dos precedentes que ainda vigorava na República Popular da China. A esse respeito, veja-se James Gordley The Philosophical Foundations of Modern Contract Doctrine (Clarendon Press: Oxford), p. 1.
} 
E o fundamento para a comutatividade vista como o que alinhava todas as partes do Direito Privado é - ei-la - a autonomia, no sentido kantiano da palavra: a rigor, a "autodeterminação", como a ela se refere Weinrib. Pois afinal o Direito Privado não seria outra coisa senão, de novo com Kant, "o conjunto de condições sob as quais a escolha de um pode ser unida com a escolha de outro, de acordo com uma lei universal da liberdade", nas precisas palavras da Metafisica dos Costumes.

Kant equipara a esfera da legalidade com as relações externas de uma pessoa, distinguindo-a assim da ética, que ele considera como a ação do ponto de vista interno do ator. O foco de sua filosofia jurídica não está na bondade de uma ação, mas na sua consistência com a liberdade de todas as pessoas. Sua exposição do conceito de direito contém a formulação mais geral desta consistência. O certo [right] (das Recht) é "a soma das condições em que a escolha de um pode ser unida com a escolha de um outro, de acordo com uma lei universal de liberdade". O direito, então, combina as noções de relação externo e de livre arbítrio na forma mais abstrata. Por conseguinte, a união de externalidade e liberdade no conceito do que é certo [right $]$ permite que o direito $[l a w]$ seja entendido como uma idéia da razão com realidade prática. ${ }^{32}$

Ou seja, a esfera da liberdade está delimitada por um teste, precisamente aquele que examinamos acima: uma ação universalizável, porque apta a ultrapassar a particularidade do agente, e portanto capaz de alçar-se a uma norma de observância universal. Supõe seu esvaziamento, a abstração de sua condição socio-histórica. Noutros termos, o Direito Privado é a face sancionatória, ou seja, o baixo relevo de um formalismo ético, em termos kantianos. Cada norma que constitui o Direito Privado corresponde a um dever fundado numa "lei universal da liberdade". Uma vez que os agentes autônomos são $i$ guais no que diz respeito a sua vontade livre, qualquer ação livre de um agente deve ser consistente com a liberdade de outrem. O teste, portanto, é kantiano, supõe que as relações do Direito Privado são estritamente bilaterais (a justiça é comutativa, não distributiva) e que suas normas consistem na demarcação legal da esfera da liberdade, correspondendo à positivação sancionatória dos deveres que a protegem, ao mesmo tempo em que a constituem autonomamente. O direito nada mais é do que a "manifestação jurídica" da ação efetivamente autodeterminada.

Conseqüências? Inúmeras podem ser imediatamente entrevistas, duas das quais são relevantes para a reconstrução argumentativa. A primeira, como já antecipamos, é a rejeição de uma explicação distributivista dos fundamentos do Direito Privado. Esse ramo do direito trata de "relações comutativas entre partes iguais", pois os indivíduos são equiparados a partir da reconstrução kantiana de sua personalidade autônoma. É assim que até mesmo a "estrutura do raciocínio jurídico" — no caso, judicial — será tra- 
duzido nesses termos neokantianos por Weinrib. "Ao elucidar o significado da interação", afirma Weinrib,

o juiz deve tratar as partes como os livres arbítrios que seu papel pressupõe que elas sejam. Porque as partes são afetadas, mas não determinadas por inclinação, suas necessidades ou desejos não determinam o significado jurídico da transação entre eles. O livre-arbítrio atua sob a causalidade de conceitos, e assim a inteligibilidade da relação de um livre-arbítrio para com outro requer uma abstração a partir das motivações privadas e dos interesses particulares das partes na direção de uma estrutura conceitual coerente que possa expressar a natureza jurídica de sua relação e possa constituir o quadro para a justificação pública da decisão do juiz. Deste ponto de vista, também, cálculos complexos de vantagem coletiva estão excluídos, porque estão além dos limites da competência judicial. A atividade do juiz consiste em tornar explícitas as categorias de propriedade, contrato e ato ilícito que estão implícitas no conceito de direito, em articular as subcategorias que constituem estas categorias mais abrangentes, e no exercício de um juízo que relaciona o caso particular à mão com os conceitos gerais que o tornam inteligível como uma interação de vontades livres. ${ }^{33}$

As relações entre indivíduos são decodificadas como paritárias, binárias, redutíveis à ação abstratamente livre de um e a ação também abstratamente livre de outro. Entende-se assim que o Direito Privado seja visto pelo prisma exclusivo da justiça comutativa e esta, por seu turno, se resolva na responsabilidade civil. Não importa, para compreendermos o Direito Privado, um exame a partir das conseqüências das relações jurídicas que são travadas entre os indivíduos. É irrelevante, ou mais ainda, inadequada uma análise a partir desse ângulo, pelo que Weinrib contesta qualquer teoria funcionalista, seja ela utilitarista, seja liberal-distributivista: o Direito Privado não é um instrumento para implementar fins como "eficiência econômica" ou restaurar, pela via das relações horizontais (não-estatais, ou seja, não verticais: indivíduo-indivíduo e não indivíduo-Estado), uma distribuição equânime da riqueza.

A segunda, que se segue daí, é a afirmação da independência, no sentido mais forte da palavra, do Direito Privado diante do assim chamado "Direito Público". Tais categorias foram relativizadas, dentro do direito, ${ }^{34}$ a partir de uma interpretação publicista do Direito Privado nascida na primeira metade do século XX, convergindo para a moda de sua "constitucionalização" nas décadas seguintes. Ora, se o Direito Privado constitui um conjunto de normas que protegem as regras que expressam deveres de proteção à esfera da liberdade da ação efetivamente dotada de autonomia, estará protegido contra a

\footnotetext{
32 Ernst Weinrib, The Idea of Private Law, op. cit., p. 95.

${ }^{33}$ Ernst Weinrib, The Idea of Private Law, op. cit., p. 105-106 (grifei). "Livre arbítrio" está traduzindo "free will", que também traduzimos por "vontade livre".

${ }^{34}$ A crítica à distinção remonta no mínimo aos Grundrisse, de Marx. No direito, porém, a separação reiteradamente repetida entre os dois "ramos" do direito, refletia ideologicamente a distinção entre a sociedade civil (esfera da circulação do capital) e do Estado.
} 
colonização de seu território por normas de direito "público". O que até o século XIX era uma distinção nítida, e que posteriormente passa a tornar-se esbatida, cada vez mais desbotada, volta a ganhar uma linha demarcatória precisa. Daí o título do livro, que já antecipa o resultado final de seu último capítulo: faz perfeitamente sentido, dadas essas premissas, falar num Direito Privado, ao lado, adjacente e inequivocamente delimitado perante o "Direito Público" — ramo que, de comandante, se torna meramente residual, definido mais uma vez, e conforme a tradição histórica, como tudo aquilo que não disser respeito ao direito "privado". Reconstrução da primeira figura do indivíduo abstrato, que compõe a "sociedade civil" onde as "esferas de liberdade" (a imagem da esfera é eloqüente) devem respeitar-se umas às outras.

\section{O glóbulo diáfano}

A teoria de Weinrib é exemplar porque desenvolve filosoficamente um conceito operacional da dogmática do Direito Privado: o de "esfera de autonomia". A esfera de autonomia corresponde ao conjunto de ações individuais acolhidas pelo direito e que corresponde, assim, à proteção de seus interesses. A “esfera da autonomia” individual, que deve ser respeitada reciprocamente por todos os indivíduos, é circunscrita pelas esferas de autonomia alheias e vice-versa. Tal sistema de fronteiras é traçado com o escalpelo da "regra universalizante", como teste positivo, e da efetiva autonomia, como teste negativo.

Indivíduos autônomos, portanto, podem autodeterminar-se conforme regras racionais, cuja estrutura é a da limitação recíproca das condutas. Para utilizarmos uma imagem de forma nenhuma imprópria, o indivíduo, átomo das relações jurídicas - e que o

Direito Privado concebe como elemento fundamental da estrutura social - pode ser decomposto, internamente, em razão e vontade, de um lado, e interesses e inclinações, de outro. E possui, externamente, um "campo de irradiação" (lembremos de como o verbo "irradiar" é freqüente na dogmática civilista de filiação kantiana) que forma uma "esfera", a ser protegida e a não ser absorvida ou ser interferida por outras esferas de liberdade alheias. O limite da esfera de liberdade que o direito protege não é arbitrário, mas traduz a limitação recíproca das ações universalmente possíveis (lembremos da força vinculante da palavra emprenhada, ou seja, da proteção da legítima expectativa no terreno dos contratos, por exemplo). Um vaso de vidro com bolas de gude. Vontade efetivamente autônoma, ou seja, não determinada, é vontade comandada pela razão e cuja máxima é universalizável, o que garantiria a convivência de todos os indivíduos iguais 
e, portanto, igualmente livres. Não fosse o ser humano um ente cindido por uma dualidade essencial, ou seja, fosse ele, ainda que finito, exclusivamente racional (os anjos, se existirem, são assim), talvez só existisse o Direito Processual Civil, e ainda assim para dirimir disputas fáticas entre indivíduos em perfeita boa-fé, nunca para dirimir questões jurídicas.

Átomos formam moléculas. As relações jurídicas correspondem à combinação de átomos, formando compostos. Contratos nada mais são do que isso, "valências" (no sentido químico da palavra), já que expressariam a autonomia da vontade de indivíduos que não são obrigados por absolutamente nada — são concebidos como iguais e livres - a contratarem. Uma vez que o fizeram, suas vontades "se vinculam", como íons de cloro e sódio que formam o sal da mesa de jantar. Pois eis aí o retrato de um indivíduo que se autoimpõe, se autodetermina, que expressa sua espontaneidade independente. Um globo de cristal, abstrato, diáfano, sem mácula, mas também sem lastro social nem história: tais são os indivíduos verdadeiramente autônomos, cuja vontade não é determinada por mais nada além de si própria. E que, por serem assim, devem ser obrigados a cumprir suas promessas ou indenizarem os danos causados.

Ou deveriam ser autônomos. E na medida em que não o são, o descompasso é tomado como "patologia jurídica", não reconhecido como fratura ou distorção da imagem. O descumprimento do dever de cuidado ou o contrato não cumprido decorrem da heteronomia da vontade, seja porque uma das partes, em vez de cumprir racionalmente com o que a razão lhe impõe como regra ética, dobrou-se às inclinações particulares (e o direito deve proteger a parte contrária — não se protege o egoísmo), seja porque, ao revés, sujeitou-se à vontade alheia em circunstâncias que excluiriam sua plena autonomia (e o direito deve protegê-la). ${ }^{35}$ Assim, o desequilíbrio e a desigualdade fáticas são traduzidas como patologias. O modelo continua o do indivíduo cuja vontade pode comandar a si própria, razão pela qual a desconformidade a esse modelo só consegue ser explicada

\footnotetext{
${ }^{35}$ O homem "honesto e probo" é, assim, conseqüência imediata da idéia de que o direito constitui-se num sistema que regula as esferas recíprocas de liberdade dos indivíduos (mais uma vez, Weinrib, The Idea of Private Law, op. cit., p. 100-102, ao discutir os preceitos de Ulpiano). Destaque-se que a imposição de deveres correlatos ao homem honesto aparece por toda parte no Direito Privado. Basta um único exemplo, da Lei das Sociedades por Ações (art. 153): "O administrador da companhia deve empregar, no exercício de suas funções, o cuidado e diligência que todo homem ativo e probo costuma empregar na administração dos seus próprios negócios." (Voltaremos a esse dispositivo legal várias vezes neste trabalho. Não será inútil para o leitor guardá-lo sobre a mesa de trabalho.) Se se preferir outros exemplos, o Direito do Consumidor os apresenta já no art. $4 .^{\circ}$, inciso III (dever de boa-fé das partes); a Lei de Locações no art. 23, inciso I ("servir-se do imóvel para o uso convencionado ou presumido, compatível com a natureza deste e com o fim a que se destina, devendo tratá-lo
} 
pela constante tradução nos termos de relações entre indivíduos permanentemente abstratos. A molecularidade corresponde à comutatividade, e esta à igualdade abstrata numa sociedade contemplada como um aglomerado de mônadas capazes em geral de autodeterminar-se. Se não o fazem, das duas, uma: ou porque sucumbiram a suas inclinações (e não merecem proteção, mas sanção), ou porque foram compelidas a tanto. O retrato do indivíduo autônomo oculta não só a desigualdade real e de fundo-reconhecida de maneira oscilantemente ambígua e incongruente por terrenos jurídicos como o Direito Trabalhista, o Direito do Consumidor, proteção a minoritários ou a incapazes, etc. mas seu descompasso essencial com a própria substância social.

Esse primeiro retrato não é o único. Ele apenas constitui apenas a primeira abstração, sistemática sem dúvida, que parte do direito como prática para, a partir daí, apresentar a maneira como a sociedade "deve ser", pois, afinal, o Direito Privado "é". Se o retrato do homem autônomo era aquele do indivíduo abstrato que só age importando-se com os efeitos que sua conduta reflete na "esfera de liberdade" alheia, um outro retrato é, porém, igualmente possível: o daquele indivíduo que apenas pensa em si.

$\mathrm{Na}$ próxima cidade teremos a oportunidade de visitar e contemplar o retrato do homem que calculava.

com o mesmo cuidado como se fosse seu."). E assim por diante. 


\section{CApítulo 2:}

\section{O ReTrato DE UM HomeM Que CAlCulava}

\section{Haplologia do átomo e partição da subjetividade}

O retrato do indivíduo autônomo não é, porém, o único que se apresenta para fundamentar o Direito Privado. Outra teoria, nascida no século XIX e renovada nos anos oitenta do século passado, partiu de um ponto de fuga diverso. O indivíduo é ainda o átomo que compõe a molécula da relação jurídica. Mas sua "estrutura fundamental”, como diriam os físicos, não é a mesma, nem são as mesmas as partículas elementares de que é composta.

O indivíduo autônomo kantiano caracterizava-se pela forte conexão entre a razão e a vontade, de um lado, e a hostilidade com respeito às inclinações, de outro. A razão comandava, e a vontade a seguia, sujeitando-se assim "apenas a si própria” (diga-se a verdade: à razão) e não a uma inclinação ou a uma outra causa externa. O retrato do homem autônomo descrevia o sujeito das relações sociais, e, no que nos diz respeito, das relações de Direito Privado, como aquele cuja subjetividade podia e devia ser inteiramente controlada e coordenada pela razão, concebida como uma faculdade robusta e apta a fornecer comandos normativos. A "razão pura prática" alcançaria regras éticas universais que estariam na base do Direito Privado e que serviriam de comando para a vontade que, não sujeita a mais nada além da própria razão, seria autônoma e, por conseguinte, livre. Impulsos, pulsões, desejos, inclinações: todos eles são reduzidos a inimigos da autonomia, justamente porque sujeitariam a vontade a um adversário externo a si mesma. A razão prática — por definição, "pura", ou seja, não contaminada pelo particularismo - , não "sujeitaria" a vontade, mas antes a "iluminaria", assegurando a possibilidade de não ser escrava das paixões. A autonomia, 
assim, supunha a tripartição da subjetividade ética, polarizada entre a razão universalizante da norma racional, as inclinações egoístas, e a vontade, que poderia curvar-se, submissa, a estas, ou comandar a si própria, se optasse pela razão.

A subjetividade do indivíduo autônomo, porém, revelava-se dotada de uma razão apta a exibir a norma universal a partir do despojamento dos elementos particulares da experiência do indivíduo e de seu teste de compatibilidade com as máximas das ações de outros indivíduos. Essa razão perderá sua opulência, porém, em outro retrato do indivíduo que se apresenta agora para fundamentar o conteúdo do Direito Privado: o homem utilitarista. Se o indivíduo autônomo escondia internamente um sistema coordenado por um comando racional, uma vontade autodeterminada e a sujeição das inclinações, o homem utilitarista é um átomo composto pela justaposição de uma razão instrumental e um conjunto de desejos, inclinações, paixões, emoções que dela se valem para alcançar o fim para que se dirigem. Essa haplologia do átomo, essa partição da subjetividade do indivíduo, altera a natureza da razão e suas relações com as inclinações, agora tratadas como "necessidades" e “interesses". Se a vontade racional kantiana as hostilizava, a razão utilitarista se sujeitará a elas com a humildade de uma serva obediente.

A composição final do retrato mostrará o Estado, o direito e a sociedade como um sistema de coordenação de um agregado de átomos, e não como uma estrutura ética racional. Átomos, cuja interação entre si, num movimento browniano de entrechoque, conduz a uma média que produz o máximo com o mínimo. A proteção legal vertida em normas jurídicas de Direito Privado apenas reflete um mecanismo de maximização, em que o Estado se torna prosseguimento de uma razão ancilar. O direito como instrumento de maximização, sua necessária conformação a essa função (daí a funcionalização do Direito Privado e sua perda de autonomia, tão temidas pelo neokantismo), incluindo a própria prática jurisdicional, e o comando exegético de que deva ser assim interpretado, são as conseqüências últimas desse "modelo" - termo que tal tradição emprega sem a menor parcimônia.

Vejamos os detalhes do retrato de um homem que não se pretende autônomo, mas apenas um indivíduo que se esmera e se orgulha em "calcular bem".

\section{A neutralidade moral da pulsão}

Quaisquer que fossem as inclinações, estas eram, para Kant, essencialmente egoístas. Por definição uma inclinação tenderia a satisfazer interesses particulares do indivíduo, ainda que fossem tão cândidos quanto o "buscar prazer no bem do outro". Inclinações, as- 
sim, abrangiam o conjunto de tendências psicobiológicas que ancoravam o indivíduo na sua dimensão egoística, seja social, seja, mais precisamente, meramente animal (prazer sexual, alimento, bebida, aversão ao sofrimento decorrente de sua privação, etc.). Não é de estranhar que Kant as encarasse com hostilidade: a exemplo do coator externo, as inclinações impõem ao indivíduo um rumo para sua conduta que lhe priva da autonomia. Como que "coatoras internas", as inclinações conspiram para impedir que a vontade seja autônoma, ou seja, comandada por si própria - melhor dizendo, não-heterônoma, ou, na construção kantiana, comandada "pela razão". 36

A degradação kantiana das inclinações é substituída, no utilitarismo, por sua neutralidade moral inicial. Os desejos de um indivíduo, por mais curiosos ou exóticos que sejam, valem tanto quanto o de outro qualquer. Essa neutralidade moral das "preferências" é descrita já nas primeiras páginas de Uma Introdução aos Princípios da Moral e da Legislação, de Bentham: ao definir o que signifique "utilidade" — princípio que "fundamenta este trabalho", diz ele —, temos de partir do fato de que ela é apenas uma propriedade de "qualquer objeto" que tenda a produzir "benefício, vantagem, prazer, bem ou felicidade" (e todas elas "vêm a ser a mesma coisa", afirma Bentham expressamente) ou impedir a ocorrência de "dano, dor, mal, ou infelicidade à parte cujo interesse é considerado":

Por princípio de utilidade entende-se aquele princípio que aprova ou desaprova qualquer ação, segundo a tendência que tem a aumentar ou diminuir a felicidade da pessoa cujo interesse está em jogo, ou, o que é a mesma coisa em outros termos, segundo a tendência a promover ou a comprometer a referida felicidade. Digo qualquer ação, com o que o tenciono dizer que isto vale não somente para qualquer ação de um indivíduo particular, mas também de qualquer ato ou medida de governo. [III] $\mathrm{O}$ termo utilidade designa aquela propriedade existente em qualquer coisa, propriedade em virtude da qual o objeto tende a produzir ou proporcionar benefício, vantagem, prazer, bem ou felicidade (tudo isto, no caso presente, se reduz à mesma coisa), ou (o que novamente equivale à mesma coisa) a impedir que aconteça o dano, a dor, o mal, ou a infelicidade para a parte cujo interesse está em pauta; se esta parte for a comunidade em geral, tratar-se-á da felicidade da comunidade, ao passo que, em se tratando de um indivíduo particular, estará em jogo a felicidade do mencionado indivíduo. ${ }^{37}$

\footnotetext{
${ }^{36}$ Naturalmente que essa é a transmutação iluminista da teologia moral cristã, ou mais propriamente do protestantismo pietista em que Kant foi educado. As inclinações egoístas corresponderão ao princípio do mal e tentam a vontade a não seguir o comando da regra universal colocada pela razão. A esse respeito, veja-se o clássico, mas acredito que ainda atual, de Bruno Bauch, Luther und Kant (Berlin: Reuther \& Reichard, 1904).

${ }^{37}$ Jeremy Bentham, Uma introdução aos princípios da moral e da legislação (Trad. de Luis João Baraúna. In: Os Pensadores: Bentham e John Stuart Mill. São Paulo: Abril Cultural, 1974), p. 9-10. Os grifos são nossos: atente-se que, para Bentham, no que aparentemente difere de Mill, no momento inicial parte-se de uma neutralidade do desejo. Qualitativamente eles se equivalem. Só num momento posterior, no confronto entre eles, uns deverão ceder lugar a outros conforme o critério de minimização da dor
} 
Ainda que a natureza tenda a associar determinados objetos à satisfação de certas inclinações comuns (a água mata a sede), na realidade o desejo é essencialmente individual, singular e não-universalizável. Kant e Bentham, quanto a isto, estão de acordo. O que pode causar prazer a um pode ser indiferente ou mesmo ser motivo de sofrimento a outro. Ainda que Kant, na Crítica do Juízo, tenha avançado no rumo oposto, não nega que o prazer, especialmente o tátil e principalmente o do paladar, atinge um grau de singularidade que não admite qualquer universalização: o gosto de um não é comensurável com o de outro. O utilitarismo, porém, ao decompor a subjetividade e reduzi-la a dois únicos componentes (o desejo e a razão), neutralizou moralmente todas as inclinações de todos os indivíduos. Todos os desejos são iguais perante a lei da equivalência, o que significa que as inclinações, por sua particularidade, não têm hierarquia (o que não significa que sejam equiponderáveis quanto a suas conseqüências, obviamente, tanto entre os indivíduos quanto dentro do próprio indivíduo).

A neutralidade, ou melhor, a neutralização moral do desejo significa, portanto, que, no ponto de partida, não há desejo melhor do que outro. A inclinação mais repugnante ou perversa de um indivíduo tem direito a conviver — em princípio, ressalte-se - com a mais altruísta e excelsa, dele ou de outro. O prazer é o que define o desejo, é a tendência natural a obtê-lo, fisiológica ou socialmente. Não há, nesse momento inicial, como colocá-los em hierarquia, individual ou social. Todos se equivalem, todos valem o mesmo. O instinto do assassino ou do perverso tende ao prazer tanto quanto o do filantropo ou o do imaculado.

“O Id não conhece juízos de valor, não conhece bem e mal, não conhece moral. O fator econômico — ou quantitativo, se preferirem — intimamente ligado ao princípio do prazer, governa todos os processos. Investimentos instintuais que exigem descarga, isso é

e de aumento do prazer. Para Mill, ao contrário, a diferenciação qualitativa dos prazeres encontra-se já no ponto de partida: "É totalmente compatível com o princípio da utilidade reconhecer o fato de que alguns tipos de prazer são mais desejáveis e valiosos do que outros. Seria absurdo supor que, enquanto que na avaliação de todas as outras coisas se considera tanto a qualidade como a quantidade, a avaliação dos prazeres dependesse apenas da quantidade. Se me perguntarem o que entendo pela diferença qualitativa de prazeres, ou por aquilo que torna um prazer mais valioso do que outro, simplesmente enquanto prazer e não por ser maior em quantidade, só há uma resposta possível. De dois prazeres, se houver um ao qual todos ou quase todos aqueles que tiveram a experiência de ambos derem uma preferência decidida, independentemente de sentirem qualquer obrigação moral para o preferir, então será esse o prazer mais desejável. Se um dos dois for colocado, por aqueles que estão competentemente familiarizados com ambos, tão acima do outro que eles o preferem mesmo sabendo que é acompanhado de um maior descontentamento, e se não abdicariam dele por qualquer quantidade do outro prazer acessível à sua natureza, então teremos razão para atribuir ao deleite preferido uma superioridade em qualidade que ultrapassa de tal modo a quantidade que esta se torna, por comparação, pouco importante.” (John Stuart Mill, 
tudo o que há no Id, acreditamos nós." ${ }^{38}$ A pulsão é moralmente neutra, desconhece critérios morais, temporais ou espaciais, dirá Freud nas Novas Conferências Introdutórias à Psicanálise, um século depois de Uma Introdução aos Princípios da Moral e da Legislação. Neutra moralmente, tendendo à satisfação máxima e imediata, sua avaliação não estará nela própria, mas fora dela. Ela não traz consigo o critério que faça dela boa ou má. E as regras para a "administração de seus conflitos" com as pretensões de outras (tanto no indivíduo quanto de outros indivíduos) à satisfação, à primeira vista legítimas, não se encontram nelas próprias. Encontram-se nos resultados.

\section{A razão comissária e zelosa}

Em nome de tais comitentes, todos ávidos de atingir o máximo de satisfação, uma outra faculdade, ancilar e comissária, estará à disposição. A razão apresenta-se, assim, aparentemente contraída e reduzida a um instrumento de cálculo que examina os fins, sua compatibilidade com o máximo de prazer possível a ser alcançado, o máximo de dor a ser banido, e os meios disponíveis ou a serem obtidos para atingir essa finalidade. A razão, portanto, é uma faculdade (inclusive social, como veremos adiante), que está a serviço das inclinações, e não o contrário. Seu objetivo é satisfazer maximalmente os interesses individuais, compatibilizando-os conforme o critério da maximização do prazer e minimização da dor:

Diz-se que uma coisa promove o interesse de um indivíduo, quando tende a aumentar a soma total de seus prazeres, ou então, o que vale afirmar o mesmo, quando tende a diminuir a soma total de suas dores. [VI] Por conseguinte, afirmar-se-á que uma determinada ação está em conformidade com o princípio da utilidade, ou, para ser mais breve, à utilidade, quando a tendência que ela tem a aumentar a felicidade for maior do que qualquer tendência que tenha a diminuí-la. ${ }^{39}$

Se em Kant a razão comandava uma faculdade denominada vontade, através de decretos (“decretos da razão prática") que lhe ofereciam regras morais universalizáveis, agora ela nada mais parece ser do que mero agente que firmou um contrato de corretagem com as inclinações e procura satisfazer-lhes os interesses. Como comissária, sujeita-se aos interesses dos constituintes e correrá em busca de sua satisfação, compatibilizando seus objetivos na medida do possível e ao máximo. Se a razão kantiana exibia a robustez do comandante,

O Utilitarismo. Trad. e introd. de Pedro Galvão. Porto: Porto Editora, 2005, p. 49-50).

${ }^{38}$ Sigmund Freud, Novas Conferências Introdutórias à Psicanálise (Trad. de Paulo Cesar Souza. In: Sigmund Freud, Obras Completas, vol. 18. São Paulo: Companhia das Letras, 2010), p. 155. 
a razão utilitarista apresenta-se na humildade de um servidor, inteligente, sem dúvida, mas subordinado e que não discute os interesses de seu contratante. Uma razão servil.

Para que seu cálculo seja factível, porém, o cômputo exige que haja um denominador comum entre as satisfações dos diferentes desejos. Dito de outra forma, se a natureza individual tende à satisfação dos desejos, sua frustração pode acarretar sofrimento, mas sua realização desmedida e impensada, além de prazer, também pode trazer consigo dor. Dor e prazer, portanto, são as medidas que permitem à razão calcular, de início individualmente e a seguir, coletivamente, se um desejo deve ser preterido em proveito de outro, se parcial ou totalmente, se neste momento ou noutro mais adequado. Prazeres e dores são individuais, tanto em qualidade quanto em quantidade: indivíduos diferentes possuem desejos diferentes, tanto quanto prazeres e dores diversos, e mesmo aqueles comuns, ocorrem em intensidades diversas. A razão comissária atuará com zelo para que, no plano ainda exclusivamente individual, a maior parte das inclinações possa ver-se satisfeita.

O cálculo, naturalmente, não é singelo e não prescinde das próprias habilidades pessoais dessa razão comissária. Quanto mais hábil e talentosa, maior a capacidade de satisfazer ao máximo as pretensões de seus constituintes. ${ }^{40}$ É assim que, para que a maioria dos desejos possa satisfazer-se, em parte que seja, outros terão de transigir ou mesmo sucumbir. Se o prazer decorrente da satisfação de um desejo tiver como contrapartida uma dor que comprometa a saúde ou a vida do próprio indivíduo, sua satisfação terá de ser eliminada. Se, comparando o prazer a ser obtido com a dor que daí decorrerá, concluirmos que esta é maior do que aquela, um terá de transigir com o outro, talvez adiando, talvez restringindo sua satisfação. E assim por diante.

Se as conseqüências, portanto, são o critério último de avaliação das condutas no plano individual (daí porque a família utilitarista tem sido caracterizada como uma "ética conseqüencialista", por oposição à ética “deontológica" ou “do dever”, de matriz kantiana), é possível ampliar o cálculo a uma instituição que, se bem gerida, pode servir como exten-

\footnotetext{
${ }^{39}$ Jeremy Bentham, Uma introdução aos princípios da moral e da legislação, op. cit., p. 10.

${ }^{40}$ Mill, por exemplo, exorta para uma "educação da sensibilidade": "Que meios existem para determinar qual é a mais aguda de duas dores, ou a mais intensa de duas sensações aprazíveis, a não ser o sufrágio geral dos que estão familiarizados com ambas? Nem as dores nem os prazeres são homogêneos, e a dor tem sempre uma natureza diferente da do prazer. Como se pode decidir se vale a pena perseguir um prazer específico à custa de uma dor específica a não ser pelos sentimentos e pelo juízo dos experientes? Por isso, esses sentimentos e esse juízo têm direito à mesma consideração quando declaram que, independentemente da questão da intensidade, o tipo de prazeres resultantes das faculdades superiores é preferível ao daqueles que são acessíveis à natureza animal separada das faculdades superiores." (O Utili-
} 
são dos recursos individuais de satisfação dos desejos. A "comunidade", assim, é de ser vista como um instrumento que deve permitir a Robinson Crusoé poder satisfazer mais do que se permanecesse sozinho em sua ilha, sem Sexta Feira, limitado portanto a suas capacidades individuais. ${ }^{41}$ A divisão social do trabalho - é nisso que Bentham e mais especialmente John Stuart Mill estão pensando - é útil porque proporciona maior produção e maior qualidade de bens e serviços que o indivíduo solitário não seria capaz de produzir. ${ }^{42}$ A sociedade, assim, é um prolongamento dos recursos individuais, potencializa os instrumentos a sua disposição e fornece-lhe outros, possibilitando que mais desejos sejam mais plenamente satisfeitos para mais indivíduos.

Quando, porém, indivíduos se agregam numa comunidade (tendo esta uma função: ampliar a satisfação de seus interesses), se por um lado eles obtêm um ganho, por outro, esse novo instrumento lhes impõe, para tanto, condições, cujas conseqüências são, de um lado, o alargamento do campo de interesses satisfeitos, ao preço de reprimir um outro território de desejos. O direito e, com ele, o Estado, nascem justamente da necessidade de "coordenar" desejos de inúmeros indivíduos, incompatíveis em natureza ou em intensidade. ${ }^{43}$

tarismo, op. cit., p. 52).

${ }^{41}$ Há referências expressas a Robinson Crusoé tanto em Bentham quanto em John Stuart Mill. Em Bentham a imagem servirá mesmo de fundamento para o direito de propriedade no seu projeto de Código Civil (parte de um "Código Geral das Leis"), reproduzindo a relação de apossamento originária desenvolvida por Locke.

${ }^{42}$ Mill é expresso nos Princípios de Economia Política: "Isso quanto à separação em ocupações, forma de associação de trabalho sem a qual não podem existir os primeiros rudimentos de civilização industrial. Mas quando essa separação se encontra totalmente estabelecida, quando se torna geral a prática de cada produtor fornecer a muitos outros determinada mercadoria e de receber de outros a maior parte das coisas que consome, há razões não menos reais, embora menos imperativas, que constituem um convite à ampliação do mesmo princípio. Constata-se que a força produtiva do trabalho aumenta com a diversificação crescente das ocupações, com a subdivisão constante do processo de trabalho, de maneira que cada trabalhador se limite a um número ainda menor de operações simples. E assim surgem no devido momento os casos notáveis da assim chamada divisão do trabalho, com a qual estão familiarizados todos os que lêem sobre assuntos dessa natureza." (Princípios de Economia Política. Trad. de Luiz João Baraúna. In: Os Economistas - John Stuart Mill. São Paulo: Nova Cultural, 1996, p. 171).

${ }^{43}$ Mais uma vez, vale a pena atentar para a crítica de Freud em A Civilização e seus Descontentes neste ponto específico: a cultura não surge sem um custo elevado, de um estado de "infelicidade interna permanente". Quanto mais Eros é sublimado, maior é o espaço para as pulsões de morte e, assim, mais fica à mercê de um superego sádico. O fortalecimento do superego, ou seja, do controle social (inclua-se aquele exercido diretamente pelo direito) e do cálculo racional, não tem como resultado a satisfação das preferências e o alcance do máximo prazer. Antes, o contrário. A crítica já aparecia na Genealogia da Moral, de Nietzsche: para ambos, a concepção da sociedade como instrumento para a maximização das pulsões ou do instinto é uma ilusão; o resultado é o oposto de si mesmo. A esse respeito, veja-se Terry Eagleton, A idéia de cultura (São Paulo: UNESP, 2005) p. 154-158. 


\section{O máximo com o mínimo}

Desejos, do ponto de vista objetivo, expressam-se em preferências, economicamente mensuráveis. "Do ponto de vista objetivo" significa que são desnecessárias incursões na subjetividade individual. Pouco importa a massa meândrica dos desejos de um indivíduo, freqüentemente entremeados, freqüentemente incapaz de ponderar qual the é mais importante. "As médias descontam tudo", diz um suposto teorema da Economia Financeira. Um conjunto de indivíduos interagindo num espaço socioinstitucional tenderá a expressar seus desejos e, na média, compensar diferenças de inteligência, racionalidade, idiossincrasias várias e outras características ou situações particulares. Assim, a sociedade é um artefato (pouco importa se natural ou artificial) que pode ser compreendido a partir de sua função, que é a de ampliar a satisfação possível dos desejos individuais, qualitativa e quantitativamente. Expressos, portanto, socialmente, tais desejos assumem a forma de preferências.

Vimos, porém, que, se por um lado esse mecanismo amplia, por outro lado impõe condições, de sorte que grande número de desejos terá de ser descartado, no meio social, para que outros possam ser satisfeitos. Em teoria, ao menos, serão os mais importantes ou prementes. Mas além de servir como instrumento que incrementa a produtividade individual, a "satisfatibilidade" dos desejos, a vida em sociedade permitiria, através da média, satisfazer o "maior número" de desejos. Essa expressão — "maior número" — é naturalmente ambígua. Satisfazer o "maior número" é algo que pode ser tomado individual ou coletivamente. No primeiro caso, indica que viver em sociedade constitui um ganho para o indivíduo e, assim, se a satisfação dos desejos de Robinson Crusoé estava limitada enquanto vivia na ilha, antes de Sexta-Feira aparecer (e se tornar, como bem sabemos, seu "instrumento civilizatório"), com o advento da vida social amplia-se a capacidade de atender uma gama maior de desejos. Assim, "maior número", num primeiro momento, significa apenas que há um benefício para o indivíduo em viver socialmente. Máxima satisfação dos desejos. Mas não só.

"Maior número" também indicaria que a vida social permite a máxima satisfação dos desejos de todos os indivíduos, tomados agora coletivamente. Imaginemos que o conjunto de desejos não está mais restrito a uma subjetividade individual. A experiência consiste em romper seus limites e imaginar que os desejos de todos os indivíduos são, na realidade, os desejos de um só. A vida social, assim, equivale a uma enorme subjetividade dotada de um número gigantesco de desejos, boa parte deles conflitantes. 
O interesse da comunidade, eis uma das expressões mais comuns que pode ocorrer na terminologia e na fraseologia moral. Em conseqüência, não é de estranhar que muitas vezes se perca de vista o seu significado exato. Se a palavra tiver um sentido, será o seguinte. A comunidade constitui um corpo fictício, composto de pessoas individuais que se consideram como constituindo os seus membros. Qual é, nesse caso, o interesse da comunidade? A soma dos interesses dos diversos membros que integram a referida comunidade. ${ }^{44}$

O que essa ultra-subjetividade que abrange a totalidade dos interesses fará é calcular como o fazia a razão zelosa e calculativa individual - quais desses desejos merecem a satisfação, e sob quais condições. Dessa luta, dessa competição pela sobrevivência dos desejos preponderantes - a rigor, das "preferências", como se verá em breve, mas por enquanto, mantenhamos ainda apenas "interesses" - nasce uma média ponderada em que o maior número de desejos será satisfeito. Retornando à esfera individual, será atendido, nesse ambiente social, o maior número de desejos individuais de todos os indivíduos, máxima satisfação dos desejos, do maior número - essa é a função e o mecanismo pelo qual operaria a sociedade: maximizando a satisfação de preferências.

Claro que uma sociedade não prescinde de normas que regulem essa atividade de interação interindividual. Uma concepção funcionalista da sociedade, em que o conflito é restrito ao nível dos indivíduos e para a qual, por princípio, o indivíduo é o ponto de partida metodológico, exigirá como conseqüência um conjunto de normas que sejam vistas como instituições que possam maximizar a satisfação de preferências. Se o indivíduo é uma mônada municiada de uma razão servil a seus desejos, e a sociedade, o aparelho amplificador de sua satisfação, esse artifício não corresponde apenas a um agregado atômico. Indivíduos podem valer-se de sua esperteza para criar expectativas que não serão cumpridas, conseguindo, com isso, ampliar ainda mais seus desejos em detrimento da satisfação de preferências dos demais. O mesmo raciocínio vale para eventuais danos perpetrados contra terceiros. Sendo assim, para que efetivamente a máxima satisfação dos desejos individuais, tomada coletivamente, seja possível, é necessária a criação de um arcabouço institucional, uma estrutura que sirva de catalisador dessa reação química. O conjunto de instituições do Direito Privado (do direito, de modo geral) é e deve ser instrumento para que todos, e não alguns apenas, obtenham o máximo do que desejam.

\footnotetext{
${ }^{44}$ Jeremy Bentham, Uma investigação sobre os princípios da moral e da legislação, op. cit., p. 10.
} 


\section{De volta para o futuro: microeconomia jurídica}

Esse retrato nos leva à família das assim autodenominadas "análises econômicas do direito”. As aspas são necessárias. Cuida-se de uma família teórica, pois as melhores análises costumam focalizar-se em particularidades jurídicas, recorrendo, por vezes, a pesquisas empíricas, como a eficiência alocativa da jurisprudência que interpretou que não descaracteriza o contrato de leasing a antecipação do valor residual garantido (Súmula $n{ }^{\circ} 263$ do STJ). Além disso, a família pode ser reconhecida antes por um conjunto de teses comuns e uma certa maneira de abordar o direito, recorrendo - com grande freqüência de maneira exclusivamente retórica - a "modelos" provenientes da Microeconomia Neoclássica, da Teoria da Eficiência Alocativa dos mercados ou da Teoria dos Jogos.

O ponto de partida é uma extensão da assim chamada "teoria da firma". Em poucas palavras, mesmo porque o desenvolvimento do tópico exigiria uma vasta digressão inoportuna, empresas buscariam sempre a maximização do lucro (pressuposto que, diga-se, não é tão óbvio assim) e o mecanismo para tanto é a produção de bens e serviços a um preço tal que coincidisse com o custo marginal de produção. A empresa produz até o limite tal que, se mais uma unidade for produzida, decrescerá o lucro marginal obtido. Nesse ponto de maximização, pelo ângulo exclusivamente microeconômico, a decisão racional é manter-se nele, não além, nem aquém. A maximização econômico-contábil dos lucros espelha o esforço de maximização da satisfação de preferências na esfera individual: o máximo do lucro equivale, para a empresa, ao máximo prazer com a mínima dor.

Pessoas jurídicas de natureza empresarial - empresas, no sentido que o direito dá a essa expressão - constituem um “instituto jurídico" cuja razão de ser é também analisável por esse prisma. O célebre artigo de Ronald Coase, de 1937, A Natureza da Firma, consiste justamente nessa tentativa. $\mathrm{O}$ autor, como sabemos, pergunta-se por que existem empresas e não antes apenas indivíduos como agentes de mercado. Se o que caracteriza a empresa é a contratação com vínculo de emprego, por oposição à mera contratação de serviços de outros indivíduos, o passo seguinte é perguntar o que se ganha em termos de eficiência alocativa optando por um regime em vez do outro. Coase retoma o conceito cunhado anos antes por John R. Commons, pai da "economia institucional", de custo de transação ("custos de utilização do mecanismo de preços", ou ainda, "custos das transações no mercado"), para concluir que, com a contratação pela relação de emprego, estes seriam reduzidos em 
vez de aumentados. ${ }^{45}$ Usar o mercado tem um custo: custo de pesquisa e de informação, custos de negociação, custos de manutenção de segredos comerciais, custos de policiamento e de execução coativa (pelo recurso ao Poder Judiciário) dos contratos. O mais importante deles, porém, é o custo de obtenção de um bem ou serviço através do mercado, que pode exceder o preço do próprio bem. A ser assim, torna-se, sob certas condições, mais eficiente realizar tais operações internamente à empresa (daí seu crescimento e mesmo sua razão de ser) do que obtê-las externamente. Como instituição jurídica, portanto, ela pode servir para redução dos custos de transação e, dessa forma, servir de mecanismo catalisador da eficiência no mercado. Mais tarde, Oliver E. Williamson expandirá a idéia, entendendo que as instituições jurídico-políticas que organizam o mercado têm por função propiciar eficiência, mas antes de tudo porque os custos de informação não são, em regra, mensuráveis. Incerteza, oportunismo e racionalidade limitada dos agentes econômicos exigem uma estrutura jurídico-econômica sem a qual o mercado não atinge o equilíbrio. Para todos, portanto, um "instituto jurídico" como o de empresa, que não é em nada "natural", deve ser decodificado a partir de sua função. ${ }^{46}$

Empresas interagem no "ambiente de mercado". Adquirem produtos e serviços e os vendem. $\mathrm{O}$ ambiente de mercado também pode ser traduzido em termos de maximização e minimização. Como a linguagem que os "indivíduos-empresas" empregam no mercado tem como vocábulo fundamental o preço, o mercado tenderá a um equilíbrio em que cada um busca maximizar o lucro, vendendo ao maior e adquirindo ao menor preço possível. Nessa interação entre os agentes de mercado forma-se um preço médio que corresponderá - a demonstração, deixemos para a fé dos economistas que acreditam nisso - a uma alocação de todos os recursos econômicos disponíveis na sociedade da forma mais eficiente possível, maximizando o lucro para todas as empresas. Ora, como indivíduos também são "agentes de mercado", suas preferências podem, ao menos metodologicamente, ser "precificadas". Indivíduos devem poder dispor (ao menos metodologicamente) numa escala de

\footnotetext{
${ }^{45}$ O caráter ideológico do artigo se revela em termos históricos: a maré da terceirização nascida a partir dos anos setenta se encarregou de apresentar conclusões no sentido oposto. A esse respeito, veja-se Richard Sennet, A Corrosão do Caráter: conseqüencias pessoais do trabalho no novo capitalismo (São Paulo: Record, 2005).

${ }^{46}$ A esse respeito, vejam-se os clássicos artigos de Ronald Coase "The Nature of the Firm" e de Oliver E. Williamson "The Economics of Organization: The Transaction Cost Approach" e "The Theory of the Firm as Governance Structure: From Choice to Contract"; bem como a obra também clássica deste ultimo, The Economic Institutions of Capitalism: Firms, Markets, Relational Contracting (Michigan: Free Press, 1985), particularmente p. 45-66, sobre o "comportamento do homem contratual".
} 
preferências seus interesses (intercambiável com as de outros indivíduos), hierarquizando quais preferem realizar em detrimento de outros, quais imediatamente, quais podem ser abandonadas para que outras subsistam, e ainda quantificar tempo e intensidade. Tal quantificação pode ser traduzida em termos de disposição a adquirir, ou seja, corresponder à "predisposição a consumir" (expressão da economia neoclássica), a pagar um preço. ${ }^{47} \mathrm{O}$ entrecruzamento, no ambiente de mercado, de todas as "falas-preço", conduziria, sob circunstâncias ideais, à maximização da produção social e a sua distribuição economicamente justa (ao menos segundo algum critério), ou seja, à "eficiência alocativa como maximização da riqueza". ${ }^{48}$

Essas circunstâncias são o terreno em que nasceria o direito e especialmente o Direito Privado. Deixado a si próprio, o mercado (ainda não um "ambiente de mercado") — o gigantesco indivíduo maximizador de satisfações — padece de falhas decorrentes de diversos fatores, dentre os principais o fato de que há agentes econômicos mercenários, que se valem de sua posição para causar danos voluntariamente ou suscitar expectativas não cumpridas. Ainda que o mercado tenda a se reequilibrar na seqüência, excluindo tais agentes ou precificando devidamente seus produtos e serviços, mais baratos, ou lhes fornecendo a preços mais caros (especialmente no tocante ao crédito), a criação de um "ambiente institucional", ou melhor, de uma estrutura jurídica que proteja a propriedade e as transações seria o instrumento necessário que atuaria como complemento da própria existência do mercado. Noutras palavras: acrescentando-se um "arcabouço jurídico-institucional" (e mesmo

${ }^{47}$ Os preços, assim, não são, para Posner, um elemento da linguagem do sistema da economia, como sustentará Luhmann (veja-se, por exemplo, Ecological Communication. Chicago: The University of Chicago Press, 1989, p. 51-62), mas um elemento da linguagem dos indivíduos que expressa, numa escala, a prioridade das preferências, no sentido mais amplo possível (envolvendo inclusive os "shadow prices", como a preferência a trabalhar ou praticar um crime). Veja-se, a esse respeito, Richard Posner, Economic Analysis of Law (Boston: Little, Braum \& Company, 1992), p. 3-20.

${ }^{48}$ Posner pretendeu ultrapassar os paradoxos do utilitarismo clássico, especialmente o paradoxo moral que manda sacrificar uma pessoa se isso conduzir ao máximo prazer de todos os demais, substituindo "prazer", "felicidade" e "interesse" pelo conceito econômico de maximização "da riqueza". Indiretamente, a maximização da riqueza, instrumento do bem-estar, refletiria (especialmente porque é "precificável"), a maximização do bem-estar em condições de eficiência alocativa. O argumento, que convenceu talvez apenas ao próprio Posner (uma torrente de críticas surgiram em resposta imediatamente após ter sido proposta), pretende consistir num atalho para contornar uma dificuldade, mas que termina por revelar-se um curto-cirtuito: o desvio recoloca a questão da utilidade da riqueza produzida, de sua precificação, das preferências e, assim, nos lança de volta à subjetividade dos indivíduos. O texto clássico de Richard Posner é "Utilitarianism, Economics, and Legal Theory" (The Journal of Legal Studies 8 (1979), p. 103-140), em que conclui que "as liberdades individuais podem ser deduzidas do princípio da maximização da riqueza", entendida como a amplitude do "conjunto de oportunidades individuais". O texto tem de ser lido com a réplica de Ronald Dworkin, "Is Wealth a Value?" (The Journal of Legal 
político: o sistema representativo funcionaria como o mercado, traduzindo, na linguagem da competição pelo poder, os interesses individuais), transferindo para ele (que também tem um custo, diga-se: o Estado, e especialmente a polícia e o Poder Judiciário, têm de ser custeados, o que envolve também sua correta precificação) o custo da transação imperfeita, seria possível atingir uma eficiência maior do que na sua ausência. ${ }^{49}$ A produção da riqueza social com um arcabouço jurídico-institucional seria, supõe a teoria, maior do que sem ela (daí sua legitimidade), e sua alocação, mais eficiente, através de um sistema de preços que emergiria de um ambiente de plena concorrência.

A rigor, justiça seja feita, a Teoria Econômica Neoclássica não ignorou o fenômeno do monopólio, em suas diversas figuras (monopólio, monopsônio, oligopólio, oligopsônio), nem da formação de cartéis. O critério, porém, para admiti-los será sempre o da eficiência. Por exemplo, podem ser necessários investimentos para a produção e comercialização de produtos que atinjam patamares que desestimulem ou impeçam agentes econômicos em situação de concorrência perfeita de fazê-los. Se é certo que o monopolista tenderá a maximizar o preço, em detrimento da maximização marginal da produção limitada pela concorrência e distorcendo assim o sistema de preços, por outro lado, sustenta a teoria, o investimento inicial deve poder ser amortizado, o que justificaria o preço maior e a alocação eficiente, ainda neste caso. Noutros casos, porém, o monopólio pode ter nascido de práticas anticoncorrenciais. Aqui a legislação antitruste estaria a serviço do alcance, mais uma vez, da eficiência. ${ }^{50}$

"Eficiência" é a pedra de toque que permite detectar se estamos diante de uma estrutura jurídico-institucional adequada ou não. O conceito, vago no senso comum, é extremamente controverso no campo da assim chamada "Economia do Bem-Estar Social" e vários modelos incompatíveis entre si, oferecendo-lhe maior ou menor formulação econômico-matemática, disputam a mão da princesa. O problema não está tanto nos diversos critérios de eficiência que se candidatam, mas nas conseqüências da admissão de um em detrimento de outro, dada sua incompatibilidade recíproca e mesmo nos paradoxos que decor-

Studies 9, (1980), p. 191-226).

${ }_{49}$ Oliver Williamson, The Economic Institutions of Capitalism: Firms, Markets, Relational Contracting, op. cit., p. 385-407.

${ }^{50}$ Para uma análise não precisamente neoclássica, veja-se, mais uma vez, Oliver Williamson, The Economic Institutions of Capitalism: Firms, Markets, Relational Contracting, op. cit., p. 365-383, que apresenta uma proposta de relativização da legislação antitruste e questiona a suposta ineficiência provocada pela existência de monopólios. 
rem de muitos deles, revelando-os contra-intuitivos.

O conhecido critério de eficiência de Pareto, por exemplo, colide com a previsão de distribuições supostamente eficientes, mas intuitivamente injustas. Uma distribuição é eficiente, simplificando ao máximo o critério de Pareto, se após a distribuição nenhum dos agentes econômicos está em situação pior que a anterior e a maioria está melhor. Ou seja, uma economia é eficiente (e a alocação de riqueza, "justa"), se atingiu os limites de sua possibilidade de produção, mas de tal forma que a cada nova distribuição, ainda que alguns agentes econômicos ganhem relativamente mais do que outros, os que ganham (na nova distribuição) relativamente menos ainda assim ganham algo a mais. A concentração de riqueza é eficiente e justa desde que beneficie a todos. O cenário alternativo seria uma economia e uma sociedade mais pobres, absoluta e relativamente. Assim, ganhariam todos, de alguma forma. Vários autores, porém, dentre eles Amartya Sen, apontaram para os paradoxos que tal critério, talvez o mais conhecido, apresenta. Sen lembra que, intuitivamente, a distribuição justa de uma pizza entre três indivíduos é de um terço para cada um. Antes da presença da pizza, nenhum indivíduo possuía pedaço nenhum. Depois, cada um receberá um terço, estando melhor do que antes. No entanto, lembra Sen, o critério de Pareto permite outras distribuições, igualmente "eficientes" e, portanto, "justas". Se dois indivíduos receberem metade, e um deles, nada, dois deles estarão em situação melhor após a divisão, e um deles não estará em situação pior do que antes (estará em situação igual). Sendo assim, se um deles receber qualquer proporção menor do que a dos outros, desde que o restante seja partilhado entre eles sem que parte da pizza (ou seja, da riqueza social) seja descartada (o que implicaria desperdício e, por conseguinte, ineficiência), estaríamos diante uma distribuição eficiente. O critério não apenas é insuficiente (oferece vários estados de eficiência alocativa) como contra-intuitivo e legitima a concentração da riqueza. ${ }^{51}$

Esta digressão é importante porque o conceito-chave das análises econômicas do direito, o de "custo de transação", só permite elaborar uma teoria do direito e uma crítica ao direito positivo e à prática jurisprudencial (e mesmo às instituições políticas) se for possível mensurar suas conseqüências e avaliá-las a partir de um padrão de eficiência alocativa.

\footnotetext{
${ }^{51}$ Para um excelente resumo do debate acerca do critério de eficiência a ser utilizado, se o direito for visto como um mecanismo regulatório, encontra-se em Matthew D. Adler, "Regulatory Theory" (In: Dennis Patterson (org.), A Companion to Philosophy of Law and Legal Theory. 2. ${ }^{\mathrm{a}}$ Ed. Oxford: Blackwell Publishing, 2010, p. 590-606). Ver Amartya Sen para uma forte crítica do paretianismo, especialmente de suas conseqüências para a liberdade (A Idéia de Justiça. Trad. de Denise Bottmann e Ricardo Doninelli Mendes. São Paulo: Companhia das Letras, 2009), p. 299-303.
} 
Se não só vários critérios são possíveis (paretiano, Kaldor-Hicks, bayesiano, etc.), mas também várias "situações de eficiência" são concebíveis, então o projeto se torna impossível, pela boa e velha razão de que não se encontrou o "princípio" que lhe sirva de fundamento. Restarão, com o valor que lhes é devido, as análises empíricas do impacto do direito nas relações econômicas, análises essas ora assumidamente humildes, ora extremamente presunçosas.

Como quer que seja, admitindo-se existir um critério que permita avaliar se uma distribuição alocativa é eficiente ("satisfaz maximalmente as preferências", ou produz maximalmente riqueza, ou o que quer que seja), o direito não será outra coisa senão o conjunto de normas que, existindo, facilitam a distribuição alocativa eficiente da riqueza social. Utilizando a terminologia da escola: se há "custos de transação", estes devem ser minimizados e alocados eficientemente entre os agentes econômicos de forma a alcançar-se, no ambiente de mercado, uma situação alocativa que produza a maximização de riqueza. A disciplina de tais custos pelo Direito Privado (responsabilidade civil, personalidade jurídica e estrutura da empresa, contratos, até mesmo Direito Sucessório ou Direito de Família), atingindo até mesmo o Direito Penal (função dissuasiva da pena, custo social de sua aplicação, etc.), corresponderia e deveria corresponder a sua função. ${ }^{52}$

Claro que, num quadro assim, o Direito Privado perde seu território para um invasor: a microeconomia, ou antes, a Teoria da Eficiência. O cuidado do neokantismo em discriminar e demarcar o território do Direito Privado por meio da noção forte de autonomia privada, fonte de normas ético-jurídicas gerais que todos os indivíduos racionais devem poder obedecer, é invadido pela nação vizinha, que se alastra sobre toda sua extensão e alcança todos os rincões. E há razões metodológicas para tanto. Se, afinal, a sociedade deve ser vista como um agregado de indivíduos ("individualismo metodológico") que tendem a maximizar suas preferências no ambiente de mercado, e se essa maximização coincide com a eficiência alocativa da riqueza, então todas as normas jurídicas deverão ser entendidas funcionalmente, a partir desse fim, que lhe é exterior. Normas novas podem ser introduzidas a partir dele, normas antigas podem ser excluídas por não se mostrarem eficientes, ou ser interpretadas conforme essa função última. Fundamento e crítica do direito nascem, agora, a

\footnotetext{
${ }^{52}$ São os correspondentes capítulos de Economic Analysis of Law, de Posner, em que coloca sob sua lente os principais institutos do Direito Privado - propriedade, contratos, direito de família, responsabilidade extracontratual - , passa ao Direito Penal e finalmente chega ao Direito Econômico (antitruste, regulação), ao Direito de Empresa e ao Direito Público (Tributário, Processual, Constitucional). O pro-
} 
partir de um fim que lhe é exterior, em evidente contraste com a teoria da autonomia da vontade, para quem o fundamento e o critério eram interiores ao Direito Privado - a rigor, não podiam sequer ultrapassar a fronteira fortemente vigiada daquela faculdade do glóbulo diáfano que se denominava razão.

\section{Legislando, interpretando, decidindo}

Essa concepção do direito recebeu sua forma mais acabada no livro do prolífico Richard Posner, o clássico The Economic Analysis of Law, de 1972, que já mencionamos. ${ }^{53}$ "Análise", "econômica" e "do direito" passa a indicar um ambicioso programa com dois objetivos. De um lado, indica a tarefa empírica de verificar as conseqüências do direito, tomado como conjunto de normas ou de decisões administrativas ou judiciais. Um dos pressupostos metodológicos mais surpreendentes é que, muito embora os "atores jurídicos" (produtores primários das normas, tribunais, administradores públicos) possam não ter em mente (e a maior parte do tempo não têm) a eficiência como objetivo de suas decisões, $n a$ prática elas contribuiriam, o mais das vezes, para alcançá-lo. Atuariam conforme um padrão pressuposto, não-explícito, uma espécie de "mão invisível econômico-jurídica" que caberia a essa obra trazer à tona. Um dos postulados (controversos, diga-se) da teoria é, portanto, o de que os responsáveis pela decisão ocultam seus fins por baixo de uma retórica técnico-jurídica até mesmo de si próprios. ${ }^{54}$ Podem não estar conscientes desse objetivo, mas o resultado tende para ele. De outro lado, indica a formulação de uma Teoria do Direito, que responda ao que é e ao que deve ser a partir daí.

Uma primeira conclusão, portanto, revela a natureza do direito, sob qualquer forma: o direito constitui um conjunto de normas e decisões cujo objetivo é assegurar uma estrutura jurídico-institucional que permita a maximização da produção da riqueza, entendida como utilidade social precificada. A antiga questão da filosofia do direito recebe, agora, uma resposta: responde-se o que é o direito - o Privado em primeiro lugar, mas Posner é um conquistador que deseja anexar todos os territórios possíveis a partir de The Economics of

grama é ousado e gigantesco.

${ }_{33}$ Posner alterou suas posições a partir de então, deslocando-se da análise econômica do direito para uma versão do "pragmatismo jurídico" a partir de The Problems of Jurisprudence, de 1990. O essencial para nosso propósito é que a obra que o notabilizou pela sistematização de um conjunto de métodos num ponto de vista coerente ilustra um dos retratos possíveis desse homem pressuposto no Direito Privado.

${ }^{54}$ Richard Posner, Economic Analysis of Law, op. cit., p. 21-28. 
Justice - apontando para sua função. Como o elemento definidor é externo a seu território, o colonizador pode também impô-lo como um deve ser.

A teoria tem aspectos normativos, bem como positivos. Embora o economista não possa dizer para a sociedade se ela deve buscar limitar o roubo, o economista pode mostrar que seria ineficiente permitir roubo ilimitado e pode, assim, clarificar o conflito de valores mostrando quanto de um valor - eficiência - tem de ser sacrificado para alcançar o outro. Ora, tomando como dado um objetivo de limitar o roubo, o economista pode ser capaz de mostrar que os meios pelos quais a sociedade tem tentado atingir aquele objetivo são ineficientes - que a sociedade pode obter mais prevenção, a um custo mais baixo, usando métodos diferentes. Se os métodos mais eficientes não prejudicassem quaisquer outros valores, seriam socialmente desejáveis mesmo se a eficiência estivesse dentre as mais baixas no totem das virtudes sociais.

[...] O que podemos chamar de teoria da eficiência do Common Law não é que qualquer doutrina e decisão do Common Law é eficiente. Isso seria altamente improvável, dada a dificuldade das questões com as quais o direito se debate e a natureza dos incentivos dos juízes. A teoria é que o Common Law é melhor (se não perfeitamente) explicado como um sistema para maximizar a riqueza da sociedade. É menos provável que o direito codificado ou constitucional, enquanto distinto dos campos do Common Law, promovam eficiência, embora mesmo eles, como veremos, são permeados por preocupações econômicas e iluminados pela análise econômica. Tal análise é também útil para iluminar traços institucionais ou estruturais do sistema jurídico, incluindo o papel do precedente e a alocação das responsabilidades de aplicação do direito entre pessoas privadas e agências públicas. ${ }^{55}$

Se, afinal, o direito é um arcabouço institucional cujo propósito não pode ser outro senão a maximização da riqueza, então ele deve servir a essa função. A vedação humeana conforme a qual não se passa legitimamente do ser ao dever-ser, tão cara à família positivista, perde seu sentido: se o direito é o que é, então deve servir para isso.

Daí uma segunda conclusão, agora particular, apresenta um critério hermenêutico para a exegese das fontes normativas. Afinal, se já sabemos o que é o direito e como ele deve ser, então o aplicador do direito, ao deparar-se com um texto legal, deve interpretá-lo tendo em vista alcançar a maximização da produção da riqueza, ou seja, deve valer-se de um critério de eficiência ao elaborar sua exegese. O olhar deve estar além do texto, o que conduz a uma reinterpretação dos critérios hermenêuticos tradicionais do positivismo clássico e, mais ainda, a uma ruptura com um certo (e suposto) literalismo. Normas e precedentes não devem ser interpretados ao pé da letra. Deve ser interpretada como contendo um comando normativo cuja única razão de existir é possibilitar a criação desse arcabouço institucional que busca assegurar a eficiência. Assim, entre o critério (eficiência) e o significado literal da norma, escolha-se sempre o primeiro. E daí a possibilidade de, com base nesse critério,

${ }^{55}$ Richard Posner, Economic Analysis of Law, op. cit., p. 23. 
propor a alteração da legislação que conflite flagrantemente com ele. Da interpretação de lege lata com base no critério passa-se à proposta legislativa de lege ferenda também com base nele.

Uma terceira e última conseqüência é formulação de uma análise da decisão, seja ela judicial (o objeto mais freqüente de Posner) ou administrativa. Se, afinal, o direito é isso, e deve ser isso, então naturalmente que as decisões dos tribunais, tomadas agregadamente, tendem a produzir eficiência (no sistema do Common Law, como sempre). E tomadas individualmente, oferecem ao juiz um critério de decisão:

Em contrapartida, o juiz (e portanto os juristas) não pode ignorar o futuro. Dado que a decisão do juiz será um precedente que influenciará a decisão de casos futuros, o juiz deve considerar o impacto provável de decisões sobre o comportamento futuro das pessoas envolvidas em atividades que dão origem à espécie de acidente envolvido no caso diante dele. Se, por exemplo, julga-se favoravelmente ao réu com fundamento em que ele é um necessitado, ainda que descuidado, a decisão encorajará pessoas similares a serem descuidadas, um tipo de conduta que envolve um custo. Portanto, uma vez que o quadro de referência se expande para além das partes imediatas do caso, justiça e razoabilidade assumem significados mais amplos do que o que é justo ou razoável quanto a este autor e este réu. A questão passa a ser o que é um resultado justo e razoável para uma classe de atividades, e não pode ser sensatamente resolvida desconsiderando o impacto futuro de decisões alternativas sobre a freqüência de acidentes e o custo das precauções. A perspectiva ex ante não é estranha ao processo, no fim das contas. ${ }^{56}$

Decida não de forma a que a máxima de sua ação possa se tornar uma máxima de universal observância, mas sim de forma a que as conseqüências verticais (da própria decisão) e horizontais (para outras decisões, ou seja, para o sistema judicial como um todo) promovam esse objetivo. Nem poderia ser diferente, diga-se. E se os tribunais não decidem expressamente assim, pouco importa: tendencialmente, por baixo da aparência técnica que a retórica jurídica impõe ao julgadores, a eficiência estará assegurada sem que disso se apercebam. Como o direito lhes aparece é irrelevante para como ele de fato é globalmente. Mesmo quando recusam expressamente o papel de "legisladores ocasionais". 57

\section{Indivíduos sem virtude}

Se o retrato do indivíduo neokantiano era o do homem que se erguia na sua autonomia individual, opondo-se a fatores externos e internos que coagissem sua vontade, mas, para tanto, devia obediência estrita a um comando da razão, o retrato do indivíduo utilita-

\footnotetext{
${ }^{56}$ Richard Posner, Economic Analysis of Law, op. cit., p. 24.

${ }^{57}$ Richard Posner, How Judges Think (Harvard: Harvard Unversity Press, 2008), p. 93-119.
} 
rista poderia parecer muito mais modesto. Afinal, esta razão não comanda, mas é comandada. Limitada ou não por características individuais, ela é ancilar, serviente das preferências individuais que sofrerão o devido polimento no ambiente institucional de mercado. A atrofia desse indivíduo, se comparado ao robusto indivíduo autônomo, é, no entanto, apenas aparente. A vontade do indivíduo autônomo — vontade "autônoma" — era, na verdade, ancilar de uma razão que, pelo critério da universalização possível das regras, impunha o fundamento racional das relações mais básicas de Direito Privado. Todas as inclinações deveriam ser desprezadas se o que se pretendia era a verdadeira e pura autonomia do indivíduo. Se a razão deve ser pura prática, restarão apenas ela e seus comandos, cabendo à vontade uma posição serviente de implementação objetiva da ação. Desse ângulo, é possível imaginar um direito sem agentes individuais concretos, bastando conceber uma razão que seja capaz de alçar-se a um patamar de generalidade tal que, independentemente de existirem indivíduos, seu direito ainda assim seria concebível. Uma razão de seres "puramente racionais", que Kant não deixa de assimilar às possíveis "inteligências angélicas". O indivíduo translúcido da autonomia da vontade como fundamento último do direito revelase, assim, muito menos denso do que o indivíduo utilitarista, cuja razão se restringiria aparentemente a uma faculdade desesperadamente ativa, sempre à procura de um meio que realize mais e mais os fins, mas também sempre reverente aos desejos, inclinações, apetites, paixões e preferências do indivíduo.

Uma "ética da virtude" era rejeitada no contexto kantiano, et pour cause. Uma ética da virtude supõe que o objetivo de todos os atos humanos seja (ou deva ser) alcançar a felicidade, entendida esta não como prazer, mas antes como o resultado do pleno desenvolvimento das capacidades individuais. A virtude é uma predisposição adquirida através da repetição incessante da mesma ação, que faz com que o agente escolha, após deliberar racionalmente, o melhor curso de ação em cada circunstância, considerando como melhor aquilo que a "ser pleno" (desenvolver plenamente as potencialidades de sua natureza humana). Ora, se a razão, absolutamente soberana, deve comandar, não pode estar a serviço de nada mais a não ser a universalização da regra que, na realidade, é uma atividade de discriminação e demarcação de limites entre esferas de direitos individuais. Não é por acaso que a felicidade, se houver, deverá ser postulada como o ponto de convergência de retas distintas num mundo para além da vida, para Kant. Afinal, não há como no mundo que conhecemos imaginar a harmonia entre o dever e o prazer, entre a norma e a alegria do respeito pela norma, sem que um deles tenha de ceder lugar inteiramente ao outro. 
Se virtude era um conceito que não aparecia no retrato do homem autônomo, que agia por dever e não procurando sua perfeição possível, ela tampouco aparecia no retrato do homem que calculava. "Felicidade" consistirá na maximização das preferências individuais, e não se fazia presente, aqui, a idéia de um indivíduo cuja essência lhe impõe a finalidade de desenvolvê-la na sua integridade. Indivíduos preguiçosos pagarão um preço, dirá o utilitarismo, que não precisa ser descrito. $\mathrm{O}$ direito é apenas um ferramental social pelo qual se faz com que se busque assegurar que a média das preferências — talvez traduzíveis nos termos da maximização da riqueza - possa ser satisfeita. Não há razão porque imaginar um desenvolvimento individual, tanto quanto não havia razão porque supor que o direito exprimisse os limites recíprocos e racionais da liberdade interindividual. Um indivíduo autônomo é livre, e só é livre porque é autônomo; para tanto, só será livre e autônomo se estiver agindo conforme a uma máxima universalizável, cuja face institucional (dirá a Filosofia Clássica alemã: objetiva) é o direito. Um indivíduo busca maximizar suas preferências, cuja contrapartida objetiva é a precificação de bens e serviços no ambiente de mercado; preferências podem ser maximalmente satisfeitas numa sociedade em que a riqueza social é maximalmente produzida. O direito, por conseguinte, só pode ser instrumento a esse propósito. $\mathrm{O}$ direito como maximização da liberdade ou maximização das preferências: eis os dois retratos até agora examinados.

Tais retratos são de homens sem virtude. Mas há quem chame a virtude justamente para servir de fundamento do Direito Privado. 


\section{Capítulo 3:}

\section{O RETRATO DE UM HOMEM VIRTUOSO}

\section{O tempo moral}

A assim chamada no ambiente universitário norte-americano de "tradição aristotélica" $^{, 58}$ (abrangendo de Aristóteles à Escolástica Tardia do século XVII, passando, naturalmente, por Tomás de Aquino) concebe a ação moral como um ato complexo, composto de condições subjetivas do agente e condições objetivas que constituem o contexto prático da ação, e que envolve também as condições sociais em que é realizado. Para essa tradição, a ação moral processa-se no tempo, mas num tempo complexo em que o ato, antes de ser praticado, é elaborado mentalmente, "deliberado", em que se ponderam conseqüências, riscos, avaliam-se seus efeitos e, finalmente, parte-se para a prática. Realizado, o ato ainda assim inaugura uma série causal em que se imiscui a incerteza, a interferência de outras séries que poderão bloquear o resultado esperado ou determinar a produção de outro, indese-

\footnotetext{
${ }^{58}$ A expressão é usada por James Gordley insistentemente, abrangendo os "escritores na tradição aristotélica" e particularmente os autores da Escolástica tardia (séculos XVI e XVII). Seus autores preferidos são Domingo de Soto, Luis de Molina e Leonardo Lessius, basicamente os dominicanos e jesuítas da Escola do Direito Natural espanhola daquele século. Em suas próprias palavras (ele não nega): "A tradição ética aristotélica está fora de moda. William James disse uma vez, contudo, sem querer ser cortês, que muito dela poderia ser descrito como "senso comum tornado pedante"'. Resta saber se o esforço de desenraizamento histórico dessa "tradição" para tentar trazê-la à contemporaneidade (a exemplo de Weinrib também) não extermina a própria planta. Afinal, é possível ainda, depois de tudo, e especialmente da liquidação final da forma clássica da metafísica por Kant, querer retornar a Aristóteles com tanta (e suposta) ingenuidade? A esse respeito, veja-se James Gordley, The Philosophical Foundations of Modern Contract Doctrine: Property, Tort, Contract, Unjust Enrichment. (Oxford: Oxford University Press, 2006), p. 7-8.
} 
jado. Subjetivamente ainda, a prática do ato pode decorrer de uma ponderação inadequada, proveniente da ausência de alguma informação relevante que, se o agente a ela tivesse tido acesso, teria alterado por completo sua decisão.

A ação moral, por conseguinte, dá-se num tempo, anterior e posterior à ação, e o conceito normativo central que a constrói é o de responsabilidade. A questão que a tradição aristotélica pretende responder é saber sob que condições um agente é efetivamente responsável por suas ações, ou, antes, sob que condições ele não seria responsável. Vimos rapidamente, no capítulo I, quais são esses requisitos mínimos. Eles permitem que, do lado objetivo, se justifique a aplicação de uma sanção pelas condutas que violem um padrão moral (veremos qual a seguir). Daí, naturalmente, o projeto de traduzir o direito num sistema de normas que sistematizam a responsabilização sancionatória do agente que agiu em desconformidade com tal padrão. Do lado subjetivo, a responsabilização revela um caráter e permite a intervenção na subjetividade do agente, "moldando-o" e fornecendo-lhe também balizas decisórias. Responsabilizar o agente justifica aplicar-lhe uma punição (jurídica ou moral) que o "educará", formando seu caráter. Mas tal punição, que sempre tem natureza exemplar (outros indivíduos irão mirar-se no exemplo e pautarão suas condutas a partir dele também), também é condição para a deliberação, especialmente daqueles cujo caráter é disforme e que tenderiam a agir de outro modo, não fosse a possibilidade do castigo. Uma "economia da subjetividade", que já vimos existir no contexto utilitarista, reaparece aqui, porém enriquecida por uma complexidade que inexistia naquele contexto: uma razão calculativa, ainda, mas que calcula considerando conseqüências morais da ação e expressa antes de tudo o caráter do agente.

Se o núcleo dessa teoria ética é a responsabilidade, seu núcleo, na teoria da justiça, é o refinamento da teoria da responsabilidade civil numa teoria da justiça comutativa. Vimos no capítulo primeiro que esse conceito, desde que permanecesse num determinado patamar de generalidade, permitia a unificação do Direito Privado num sistema de proteção contra o dano causado por terceiros. Ali, no contexto neokantiano, ele se alçava num sistema de proteção recíproco às diversas esferas de liberdade individuais. Examinadas pelo verso, as normas centrais de Direito Privado - o núcleo da Teoria das Obrigações - impunham a vedação da ação causadora de dano e impunham, na sua violação, a espontânea reparação, sob pena de coação estatal (judicial, em primeiro lugar). Responsabilidade, "contratual” e 
“extracontratual", revelava-se a estrutura mais geral e robusta do Direito Privado, presente na responsabilidade dos controladores ou diretores da sociedade anônima, do gestor de negócios, do representante comercial, do locatário, do locador, do mutuário ou mutuante, ou simplesmente daquele que deve agir com cuidado e diligência na sua vida cotidiana (regra geral do art. 186 do Código Civil de 2002, que define o ato ilícito: “Aquele que, por ação ou omissão voluntária, negligência ou imprudência, violar direito e causar dano a outrem, ainda que exclusivamente moral, comete ato ilícito.”).

Já sua face formal é a formulação de uma teoria da justiça, conhecida desde Tomás de Aquino como "comutativa" (seu primeiro desenho, praticamente acabado, já se encontra na Ética a Nicômaco, de Aristóteles). A expressão "justiça comutativa”, é bom alertar, não é uniforme. ${ }^{59}$ Por essa expressão designaremos aqui sempre a forma da justiça, nessa "tradição", que é espécie do gênero "justiça particular" (ou seja, da justiça como uma virtude entre outras, por oposição à “justiça geral”, que é a face objetiva da virtude e corresponde a agir como é devido, tratando a todos como devem ser tratados, pelo que se identifica com a própria legalidade) e contrasta, dentro dele, com a "justiça distributiva", que envolve a distribuição proporcional de recursos e bens sociais numa comunidade conforme algum critério de merecimento (honra, mérito, necessidade, contribuição, esforço, etc.). Evitaremos também o preciosismo "excelência" (que o autor desta tese, em vários outros trabalhos, tendeu a empregar), que, embora etimologicamente corresponda ao termo grego areté, por outro lado é muito mais desnorteante, escondendo mais do que revelando.

A responsabilidade, como também já vimos no primeiro capítulo, pode ser elidida pela presença de uma série de causas que indicam que a série causal não decorreu do agente, em condições normais. Noutras palavras, o efeito não revela seu caráter, não mostra quem ele de fato seja. A legítima defesa, o estado de necessidade, a lesão, o dolo, a incapacidade da pessoa e especialmente a coação — tratada já no livro III da Ética a Nicômaco —, como vimos anteriormente, "afastam os efeitos" do ato, ou seja, não acarretam a responsabilização do agente. A pergunta que a tradição aristotélica revivida nos anos setenta e oitenta do século passado se colocará é justamente qual a justificativa para isso. Deixando de lado as hipóteses excepcionais da responsabilidade objetiva — que, para muitos, como já vimos, não se trata propriamente de responsabilidade — ou da proteção a partes vulne${ }^{59}$ Especialistas em Aristóteles ou na Escolástica estejam bem cientes. De toda forma, anote-se que We-
inrib prefere "corretiva", mas alerta para sua escolha divergente (Ernst Weinrib, The Idea of Private 
ráveis (Direito do Trabalho, Direito do Consumidor, acionistas minoritários, microempresas, locatários residenciais, etc.), o que poderia tornar racional e sistemática a lógica mais geral do Direito Privado, que, em última instância, impõe um dever (de cuidado) e, assim, protege o patrimônio alheio, mas admite exceções sob certas (na verdade, muitas) circunstâncias?

Essa justificação, essa "fundamentação racional” do Direito Privado na vedação do dano a partir do fio que o alinhava, a responsabilidade, apóia-se agora numa teoria moral altamente complexa e psicologicamente mais rica que as anteriores. Mas controversa, naturalmente, e não é necessária muita reflexão para desconfiar de que pressupostos metafísicos foram contrabandeados para uma teoria que renasceria como um velho jusnaturalismo aristotélico-tomista. O argumento, porém, é curiosamente "transcendental": seus defensores - John Finnis, mas, mais especificamente e no que tange ao Direito Privado, James Gordley — partem antes da existência do direito como tal e perguntam por sua "condição de possibilidade". Digamos que "se um Direito Privado deve ser possível" (e é, mesmo porque, como lembra Gordley, os principais institutos são idênticos nas duas grandes famílias jurídicas do Civil e do Common Law, e mesmo a China hoje possui um Código Civil), então suas condições de possibilidade estão preenchidas.

Examinemos como é construída essa figura do homem virtuoso, que os principais institutos do Direito Privado pressuporiam.

\section{A ultimação do desenho natural}

O aristotelismo é finalista, ou seja, sustenta que, além de "causas" (o que o empirismo terá dificuldade de aceitar) que produzem "efeitos" ("eficientes"), existem "causas finais". Uma enorme controvérsia surgiu na modernidade, sobretudo após a recusa da existência (ou ao menos sua desimportância) dessa espécie de causa a partir do século XVII, e especialmente após o esforço da biologia em prescindir de sua existência. Tais controvérsias filosóficas, cujo registro histórico não pode ser omitido, interessam, porém, pouco aqui. Se o argumento pretende partir de um fato, ou seja, a existência do direito - ou, como autores como John Finnis, de "fins últimos" das ações —, para suas condições, recolher numa teoria consistente seria o que basta.

Law, op. cit., p. 104). 
A ação moral prorroga-se num tempo que não se limita a ela. Para o aristotelismo, o desenvolvimento moral do ser humano expande a temporalidade da ação. A formação biológica do indivíduo já o constitui como um projeto que poderá ou não ser concluído no tempo de sua formação (fisiológica e moral). Assim, biologicamente o indivíduo (um ser vivo qualquer), embora sua natureza o impila a concluir-se, pode ser impedido, por fatores internos ou externos, de atingir o estado para o qual tende naturalmente. Fatores internos, como uma má-formação biológica, ou externos (todas as condições impeditivas de seu desenvolvimento completo, desde má alimentação a acidentes) podem prejudicar esse processo. Assim, o preenchimento de pré-condições é essencial para que um organismo biológico natural conclua o processo de desenvolvimento com êxito. Desse ponto de vista, se a filosofia da biologia teria muito a dizer sobre esse finalismo - a questão, como vimos, é saber se é possível prescindir das "causas finais", ou seja, da explicação funcional dos diversos processos biológicos e, principalmente, se é possível desfazer-se delas e reduzi-las a uma descrição exclusivamente material do processo de desenvolvimento - , a teoria ética, ao contrário, pode permanecer neste patamar e não pretender descer além dele. Esse postulado - muito longe de ser óbvio — é o ponto de partida da teoria neoaristotélica no direito, misto de filosofia analítica anglo-americana e neotomismo:

Escritores na tradição aristotélica acreditavam que há uma vida humana específica para a qual contribuem todas as capacidades e habilidades de alguém. Viver uma vida assim é o fim último para o qual todas as ações bem escolhidas são um meio, seja instrumentalmente, seja como partes constituintes de uma vida assim. Ações que contribuem para uma vida assim são corretas. As que desviam dela são erradas. Diferentemente de outros animais, um ser humano pode identificar as ações que realimente contribuem. Fazendo assim, uma pessoa exercita uma habilidade adquirida — uma virtude — que esses escritores denominaram "prudência". Para seguir os ditames da prudência, ele pode precisar de outras virtudes também, tal como a coragem para enfrentar a dor e o perigo, ou a temperança para renunciar ao prazer. ${ }^{60}$

Noutras palavras, o senso comum seria suficiente para atestar que seres humanos tendem a crescer e desenvolver-se como adultos, sendo necessário que, para que o processo ocorra integralmente, suas condições de desenvolvimento pleno estejam disponíveis. ${ }^{61}$

\footnotetext{
${ }^{60}$ James Gordley, The Philosophical Foundations of Modern Contract Doctrine, op. cit., p. 8.

${ }^{61}$ John Finnis, que atualmente talvez seja o principal defensor da teoria do direito natural "neotomista", com uma tentativa de adaptação para a filosofia analítica, sustenta reiteradamente que ela prescindiria de uma "teoria da natureza humana". "Ao contrário", diz ele, "Tomás de Aquino afirma tão claramente quanto possível que os primeiros princípios do direito natural, que especificam as formas básicas do bem e do mal e que podem ser adequadamente apreendidas por qualquer pessoa na idade da razão (e não apenas por metafísicos), são per se nota (autoevidentes) e indemonstráveis. Não são inferidos de princípios especulativos. Não são inferidos de fatos. Não são inferidos de proposições metafísicas sobre
} 
O senso comum ainda nos informaria que os seres humanos são dotados de "racionalidade”. Os capítulos anteriores devem ter mostrado que essa palavra é vaga o suficiente para corresponder a significados tão diversos como o de uma faculdade que impõe um comando correspondente a uma regra de universal observância ou um instrumento que se esforça por calcular meios e fins e satisfazer o máximo de preferências. A "tradição aristotélica" pretende descobrir na ação comum do homem uma racionalidade "científica", decorrente da tendência natural à busca da verdade; uma propriamente "técnica", cuja destinada à obtenção de objetos ou estados úteis (medicina, tecnologia, por exemplo, mas também a música e outras artes); e finalmente uma racionalidade "prática", cuja função é permitir a prática de ações éticas positivamente valoradas. ${ }^{62}$ Desta decorre o direito.

Ora, se essas são características dos seres humanos, compondo seu "modo de ser", então o processo de seu desenvolvimento deve conduzir, se nada der errado e tudo der certo, a sua "plenitude". A idéia, à primeira vista, nada tem de complexo ou obscuro: um ser humano plenamente humano (ou seja, em que o desenvolvimento esperado foi efetivamente atingido) é um indivíduo em que as faculdades éticas também se desenvolveram inteiramente. O padrão argumentativo é, aqui, mais uma vez o mesmo: compare-se com o que é um indivíduo moralmente torpe. Este é alguém em que sua racionalidade ética não está integralmente desenvolvida, que, por razões biográficas várias, não evoluiu para o esperado. Por conseguinte, um indivíduo virtuoso - "excelente", que atingiu seu ponto "ótimo", de qualidade plena — é aquele cujas aptidões, dentre elas a racionalidade na sua função prática, atingiram um acabamento completo. É preciso detalhar melhor esse quadro, com certeza, mas o núcleo argumentativo apenas desenvolve a premissa básica de que a transformação ontogenética pode ser compreendida como desenvolvimento, ou seja, progresso individual na direção de um estado final de conclusão determinado nela própria e para a qual ela tende naturalmente.

a natureza humana, ou sobre a natureza do bem ou do mal, ou sobre 'a função de um ser humano, nem são inferidos de uma concepção teológica da natureza ou qualquer outra concepção da natureza. Não são inferidos ou derivados de coisa nenhuma. São não-derivados (ainda que não inatos). Princípios do certo e do errado, também, são derivados destes primeiros princípios pré-morais de razoabilidade prática e não de fatos, sejam metafísicos ou outros quaisquer." O quanto valha essa série de afirmações como um argumento é para se pensar (aliás, esse constitui muito do estilo de Finnis). Seja como for, a controvérsia, como se vê, focaliza-se não só, como sempre, nas conseqüências desses primeiros princípios e quais seriam eles, mas também se realmente seria possível afastar-se do compromisso com uma metafísica. A esse respeito, veja-se John Finnis, Natural Law and Natural Rights (Oxford: Oxford University Press), p. 33-34.

${ }^{62}$ Veja-se a esse respeito, John Finnis, Natural Law and Natural Rights, op. cit., p. 59-75. 
Várias condições, tanto sociopolíticas quanto pedagógicas, ou mesmo individuais, são exigidas para que a promessa desse desenho natural possa ser cumprida. A Ética a Nicômaco foi, talvez, o primeiro tratado ético de que se tem notícia que propôs uma análise específica para o fato terrível de que possa haver indivíduos recalcitrantes à formação ética. Se a razão prática, como veremos com mais detalhes a seguir, também procura avaliar meios e ponderar fins, ela o faz conforme um padrão de medida que coincide, em última instância, com a busca da plenitude do desenvolvimento. Há, portanto, um padrão de medida, um critério para avaliar se uma ação é boa ou má. Indivíduos dessa espécie, porém, não pautam suas ações conforme esse critério, mas exclusivamente conforme a satisfação dos apetites. O que a psiquiatria do século XX passou a caracterizar como "psicopatia" ("sociopatia" ou "transtorno da personalidade dissocial", nos termos atuais do DSM-V) era descrito ali, seguindo a concepção médica da época, como uma deformação biológica do agente moral impeditiva da formação do caráter, elemento psicológico fundamental para o pleno desenvolvimento da razão prática. Esta, então, reduz-se justamente àquela razão lacaia dos apetites e paixões que vimos no utilitarismo e que só tem forças para controlá-las se houver um arcabouço social de normas que imponham sanções dolorosas aos prazeres que elas perseguem irrefreadas. Sem freios, pois seu caráter não chegou a ser formado, esse indivíduo hedonista vale-se de sua razão para alcançar "o bem aparente", não para praticar ações propriamente virtuosas que reflitam seu bom caráter.

A arrematação, portanto, da tendência envolve uma articulação da subjetividade num sistema em que as paixões e a razão se co-determinam. As primeiras são direcionadas (por um processo pedagógico, destaque-se) para seus fins naturais, sem desvio; a segunda, desenvolvida para coordenar todas as ações que realimentem essa formação da personalidade. O processo é evidentemente circular, e o sistema emocional, disciplinado pela pedagogia do caráter, confere à razão, que conhece os melhores fins (por uma pedagogia intelectual que complementa a anterior), o ímpeto necessário para que inicie uma avaliação complexa dos melhores meios e dos fins concorrentes a serem alcançados.

Essa teoria moral corresponde a uma ética da virtude e, daí, apresentaria, para a "tradição aristotélica", os fundamentos da teoria da justiça nas relações de Direito Privado. ${ }^{63}$

${ }^{63}$ A diferença entre uma "ética da virtude" e uma "ética do dever", portanto, necessariamente pressupõe a noção de desenvolvimento moral da personalidade, por oposição à de cumprimento de uma regra. Esse é talvez mais um ponto em detrimento de uma teoria que pretenda fundamentar uma teoria do direito em alguma concepção do direito natural a partir da identificação de "bens últimos" a que as ações tende- 


\section{Régua, extremos e mediatriz}

Sem uma formação (a palavra tem de ser tomada até no sentido etimológico: "dar-se forma"), a tendência tanto da razão quanto dos apetites e paixões é desviarem-se dos fins a que devem destinar-se. Desmesura é, aqui, a imagem correta: tenderão ora ao mais, ora ao menos, ora ao excesso, ora à falta. $\mathrm{O}$ exemplo mais claro é o da alimentação. A fome é a face consciente de um apetite (um instinto, diríamos nós) que nos impele a satisfazê-la e tem uma razão de ser natural: reabastecer o corpo. Mas sua satisfação não só alivia um desconforto, como aparece associada a um outro estado subjetivo, o prazer. A alimentação, assim, pode perder sua tendência natural, "desnaturar-se", desviar-se de sua função e transformar-se apenas num expediente para a obtenção de prazer. "Comer para alimentar" e “comer para obter prazer” são comportamentos diversos. O prazer não tem limites (exceto quando dispara a dor), e, assim, sem que tenham sido colocados diques de contenção, sua tendência é desviar-se de seu curso natural. A formação do caráter é um procedimento pelo qual se mantém o rio no seu leito, evitando que se desvie para o prazer, ou seja, na direção do excesso. A anorexia, por motivos outros que se pode imaginar, pode, em contrapartida, conduzir ao extremo oposto, à falta de alimento. O fim realmente apropriado à destinação natural é aquele que se coloca eqüidistante dos dois extremos, dos dois "excessos", ou seja, dos dois "desvios". Numa linha, corresponderia ao ponto médio entre eles. ${ }^{64}$

Esse é um dos elementos que compõem a definição de virtude no livro III da Ética a Nicômaco. Um indivíduo virtuoso é, obviamente, o que tem como característica a virtu-

riam, evidentes "por si mesmos", mas sem fundamento numa metafísica essencialista. Primeiro porque a mera afirmação de que tais bens, tomados abstratamente ("saber", "experiência estética", "amizade"), como o faz Finnis, deixam de ser evidentes quando se exige que se tornem concretos. E, além disso, supõem, ainda que Finnis insista no contrário, o padrão de uma psicologia humana a ser alcançada plenamente. Tal padrão não só é extraído do homem esperado numa certa formação social (de que Finnis não parecer querer se dar conta), mas, mais ainda, impõe sua relativização e sua crítica. Para uma análise dos limites e do contraste entre os dois tipos de ética, veja-se o livro de Stan van Hooft, Ética da Virtude (Petrópolis: Vozes, 2013), p. 15-25.

${ }^{64} \mathrm{O}$ quanto tal concepção, bem como a própria quadripartição da teoria aristotélica das causas (que corresponde ao modelo do senhor que comanda e do escravo que obedece), está mergulhada na ideologia do escravismo da época, pode-se descobrir no breve ensaio de Marilena Chauí, O que é ideologia? (São Paulo: Brasiliense, 2003), p. 9-24. Um trabalho que mantém a planta viva em seu ambiente natural, sem arrancá-la do chão histórico-social, é o belo e monumental livro de Geoffrey de Sainte Croix, The Class Struggle in the Ancient Greek World (Ithaca: Cornell University Press, 1981). Esses dois livros são o suficiente para alertar que o vegetal não sobrevive fora de seu ambiente histórico. Seu estudo não é irrelevante, porém: é pelo contraste, pelo reflexo, pelo que permite revelar da diferença com aquele mundo antigo, que passamos a ter consciência mais nítida da própria singularidade do nosso mundo moderno. 
de. ${ }^{65}$ Esta é uma predisposição que está nele presente a deliberar, ou seja, calcular racionalmente, ponderando todas as circunstâncias e conseqüências, e, ao final, escolher o ponto médio entre os dois extremos possíveis. Os extremos possíveis são determinados subjetiva e objetivamente. Subjetivamente, ou seja, conforme as características pessoais deste agente (velho ou jovem, homem ou mulher, etc.). Retornando ao exemplo da alimentação, comer mais ou menos dependerá de quem é este indivíduo. Quando se está doente talvez se necessite alimentar-se mais (ou menos, tudo depende da doença). E também objetivamente, conforme as circunstâncias a serem examinadas (a que horas, que alimentos, etc.). O virtuoso tem uma predisposição que não é só inata (vimos que há indivíduos resistentes a ela), mas antes de tudo adquirida pela repetição, que nele produz um hábito, tanto mais arraigado quanto mais foram repetidas tais condutas. Tantas vezes escolheu os alimentos saudáveis e na proporção correta que tal escolha se torna, por assim dizer, automática. A destinação do impulso a alimentar-se, a saciar a fome, não se excede, não se desvia, permanece nos seus limites, em igual proporção aos dois extremos possíveis. E a escolha deve ser aquela que uma pessoa prudente, isto é, dotada de sabedoria, tomaria no mesmo caso concreto. Mirar-se no espelho desses indivíduos "prudentes" (nesse sentido preciso) é também um dos elementos componentes da definição de virtude. Chega-se assim à definição final da virtude na Ética a Nicômaco:

A virtude é, pois, uma disposição de caráter relacionada com a escolha e consistente numa mediania, isto é, a mediania relativa a nós, a qual é determinada por um princípio racional próprio do homem dotado de sabedoria prática. E é um meio-termo entre dois vícios, um por excesso e outro por falta; pois que, enquanto os vícios ou vão muito longe ou ficam aquém do que é conveniente no tocante às ações e paixões, a virtude encontra e escolhe o meio-termo. E assim, no que toca à sua substância e à definição que lhe estabelece a essência, a virtude é uma mediania; com referência ao sumo bem e ao mais justo, é, porém, um extremo. ${ }^{66}$

A virtude, portanto, é um ponto médio entre os dois extremos. O exemplo exclusi-

\footnotetext{
${ }^{65}$ Mihi a docto Doctore domandatur causam et rationem, quare opium facit dormire? À quoi responde$o$, quia est in eo virtus dormitiva. Cujus est natura sensus assoupire. ("Foi-me perguntado por um douto doutor a causa e a razão por que o ópio faz dormir. A que respondo: porque nele está uma virtude dormitiva, cuja natureza é de apaziguar os sentidos." Molière, Le Malade Imaginaire, ato III, cena III.) A célebre boutade de Molière reflete o espírito da modernidade na recusa tanto das causas finais quanto da causa formal quanto na explicação a partir do par conceitual aristotélico potência ("capacidade", em alguns contextos, virtus) e ato. Para tanto, vale a pena lembrar do clássico ensaio de Rubens Rodrigues Torres Filho, “A virtus dormitiva de Kant” (In: Ensaios de Filosofia Ilustrada. São Paulo: Iluminuras), p. 31-51.

${ }_{66}^{6}$ Aristóteles, Ética a Nicômaco, II, 6, 1106a36-b7 (In: Os Pensadores - Aristóteles. tradução de Leonel Vallandro e Gerd Bornheim da versão inglesa de W.D. Ross. 4. ed., São Paulo: Nova Cultural, 1991), p. 38 .
} 
vamente individual (“a mediania relativa a nós", nas palavras de Aristóteles) que apresentamos acima pode ser reencontrado em outra virtude, aquela que servirá de base, para o neoaristotelismo, para justificar o conteúdo das normas de Direito Privado. Além da temperança, a virtude que exerce o controle dos apetites (como a fome, a sede, a libido, etc.), a fortaleza também revelará a mesma estrutura: forte é aquele que mantém a coragem perante o perigo e da dor, razoavelmente, nem escapando dele quando pode ser enfrentado, nem agindo temerariamente além de suas forças. $\mathrm{O}$ forte é o corajoso racional, eqüidistante do medroso e do temerário no enfrentamento das dificuldades. Acima delas, como virtude suprema por excelência, está a prudência, condição sem a qual das demais são impossíveis. Essa faculdade ou aptidão permite reconstruir o contexto da responsabilidade moral e, a partir daí, da responsabilidade jurídica. Ela é uma virtude ao mesmo tempo do caráter e da razão, já que constitui a capacidade de encontrar os melhores meios, dado que conhece os melhores fins. Virtude calculativa por excelência, não se limita a um cálculo, mas põe os fins a ser alcançados, pondera-os e examina as conseqüências e o contexto prático no qual a ação será realizada. Mais uma vez, com a palavra, a "tradição aristotélica":

O tipo de prudência que uma pessoa exercita ao ver que uma ação contribui para a espécie de vida que ele deve viver (nous para Aristóteles, intellectus para Tomás de Aquino) tem sido traduzida como "entendimento" ou "intuição". Denominar essa habilidade de "prudência" não explica como ela funciona. Isso equivale a dizer que de alguma maneira somos capazes de ver que algumas escolhas são certas e outras erradas. Sem uma habilidade assim nunca seríamos capazes de agir corretamente. Em todo caso, essa habilidade não é lógica dedutiva. Pessoas prudentes entendem coisas que não podem demonstrar. Fundar a ética na lógica dedutiva poderia sugerir que as mesmas escolhas são sempre certas ou erradas como as conclusões da matemática. Enquanto a prudência indica que algumas escolhas são certas ou erradas, as mesmas escolhas nem sempre são certas ou erradas para todas as pessoas. Pessoas são diferentes e assim são suas circunstâncias. Mesmo se não fossem, poderiam ainda não ser justo a escolha certa ou melhor que uma pessoa deveria fazer. Liberdade da vontade, conforme Tomás de Aquino, significa não só que alguém pode escolher fazer o certo ou o errado, mas que pode haver diferentes maneiras de escolher corretamente, nenhuma delas sendo a melhor. Contudo, a escolha pode importar muito. Importa qual dos vários possíveis edifícios um arquiteto escolhe construir, mesmo se ninguém pode hierarquizar o grau de sua beleza. Para Tomás de Aquino, importou que Deus tivesse criado o universo, mas ele discutiu a liberdade de Deus da mesma maneira que aquela dos seres vivos: não há um melhor dos mundos possíveis que Deus tivesse de criar. ${ }^{67}$

Embora conhecer o bem seja condição necessária, não é — nisto o antiplatonismo da ética aristotélica - condição suficiente, já que a força dos apetites e das paixões pode fazer o rio transbordar de seu curso (originando a figura do intemperante, que conhece o bem, mas 
não consegue praticá-lo, porque o desejo do prazer ou o medo da dor é mais forte do que ele).

Das quatro virtudes cardeais, porém, uma se mostra crucial para a fundamentação do Direito Privado. De todas elas, a justiça, virtude que preside as relações interindividuais (individualmente - justiça comutativa - ou coletivamente - justiça distributiva) seria o ponto de fuga das linhas que compõem o sistema de institutos fundamentais do Direito Privado. Antes de chegar a ela, examinemos mais de perto como ocorre a deliberação prática e como ela repercute sobre o próprio agente. O passo auxiliará a compreender o quadro geral.

\section{Avaliando antícopes}

A prudência, portanto, é uma virtude que, como as demais, depende tanto de uma predisposição inata (há quem tenha deficiência dela por natureza), mas também por sua prática constante. Ela depende, em primeiro lugar, de um aprendizado sobre o que seja o bem verdadeiro, por oposição aos bens aparentes, o primeiro dos quais o prazer. ${ }^{68} \mathrm{Sem}$ sabermos que o excesso de comida nos causa mal, confundiremos uma aparência irreal de bem com o próprio bem. A primeira condição, portanto, para uma ação virtuosa - que, como é a culminação do próprio desenvolvimento do ser humano, corresponde à atividade plena de suas faculdades e coincide com a felicidade - é ter sido desenvolvida no agente a capacidade de reconhecer, em cada caso concreto, o realmente (não apenas aparentemente) melhor.

Para a "tradição aristotélica", o conhecimento do bem não é suficiente. Já vimos que alguém pode, para Aristóteles, conhecer o bem e desejá-lo, mas ainda assim praticar uma ação reprovável, "viciosa", pois um desejo mais forte do que aquele o desviou do rumo "cor-reto", do caminho "direito". Porém, o desejo suficientemente forte (e para tanto a formação moral é o que importa) ainda assim não é suficiente. As ações são realizadas em contextos práticos, em circunstâncias particulares complexas e cujas regras, essencialmente empíricas, só admitem certo grau de generalização. A memória é essencial para guardar os resultados das ações, próprios e alheios, tanto quanto uma capacidade de análise e identificação das circunstâncias. E é também essencial ser dotado de uma capacidade de antecipar

\footnotetext{
${ }^{67}$ James Gordley, The Philosophical Foundations of Modern Contract Doctrine, op. cit. p. 8.
} 
resultados das ações, de ser capaz de coordenar meios e fins, e ponderar todos eles. A prudência, portanto, é uma capacidade complexa, como também é complexa sua atividade, sempre ameaçada pela imprudência ou pela negligência. ${ }^{69}$

A ação propriamente virtuosa supõe, portanto, uma faculdade que é capaz de imaginar os resultados, uma "imaginação produtiva" que o constrói a partir do presente, recorrendo ao passado (a "imaginação reprodutiva", isto é, a memória). A avaliação dos resultados com base num padrão moral reconhecidamente circular, que corresponde à ação virtuosa, é o fundamento da responsabilidade e da sanção, como categorias ético-jurídicas. O vicioso merece sanção, não porque com isso será possível interferir em sua economia subjetiva, alterando os termos do cálculo racional de maximização de preferências. $\mathrm{O}$ vício merece sanção porque, com isso, é estabelecido um padrão social que impõe a correção moral àquele cuja conduta se "des-via" do curso esperado. O objetivo da sanção é impor um padrão de conduta, talhar sua personalidade. Por outro lado, a norma aparece aqui também, no raciocínio prático, como razão suficiente para a deliberação ("há norma, logo, ela justifica o que devo fazer"). ${ }^{70}$ Se há sanção, é porque há responsabilidade. E responde aquele cujo princípio de sua conduta não exprime a virtude, que a nada mais corresponde do que à excelência do indivíduo, a seu pleno desenvolvimento.

${ }^{68}$ Aristóteles também menciona a honra, o dinheiro, o poder, etc. na Ética a Nicômaco.

${ }^{69}$ Ampliando a psicologia da ação, Tomás de Aquino, na Suma Teológica, indicará que são "partes integrantes" (subpartes) da prudência a memória (essencial para o registro da experiência passada), a inteligência (capacidade de apreender os princípios últimos), a docilidade (virtude intersubjetiva, que permite aprender com o conselho e a experiência dos outros), a sagacidade (habilidade para a rápida e fácil descoberta dos meios da ação) a razão (capacidade de raciocinar do geral ao particular), a previsão (capacidade de antever o futuro), a circunspecção (ponderação das circunstâncias e particularidades do caso concreto) e a precaução (ou cautela, que permite ver os impedimentos nascidos das aparências do bem). Naturalmente que a transformação da psicologia da ação de Aristóteles na de Tomás de Aquino sofre não só a reconfiguração no contexto teológico medieval, mas mesmo a resignificação dos conceitos originais. É assim que a virtude do "conselho" será interpretada agora a partir dos "dons do Espírito Santo". Longe de consistir num detalhe histórico, deve fazer-nos mais uma vez desconfiar da própria possibilidade mesmo de existir uma "tradição aristotélica". Como Gordley sustenta seu argumento não só a partir da análise do Direito Privado, mas de sua própria evolução histórica (ele crê que o Direito Privado contemporâneo assumiu a forma que conhecemos em razão do trabalho da Escola de Direito Natural espanhola), a cautela é mais do que necessária. As virtudes acima, de resto compondo um panorama da subjetividade prática bastante saboroso, encontram-se na Suma Teológica, II-II ${ }^{\mathrm{a}}$, q. 48-52. Destaque-se que nas qq. 44-45, Tomás de Aquino desenvolve os vícios da negligência e da imprudência. Nas qq. 57 e seguintes, inicia o estudo da justiça. (Tomás de Aquino, Suma de Teologia, III. Madrid: Biblioteca de Autores Cristianos, 1990, p. 415-446).

70 "Razões exclusionárias" (exclusionary reasons) ou "de preferência" (preemptive reasons), no sentido próximo ao de Joseph Raz em Practical Reason and Norms (2. ${ }^{a}$ Ed. Oxford University Press: Oxford, 1999), mas sem, é claro, o que não faria o menor sentido, o comprometimento com seu positivismo "exclusivo". 
A responsabilidade, porém, é afastada quando o resultado da ação não corresponde ao agente. Uma conduta decorre sempre de um sistema complexo em que uma base emocional é estruturada por uma educação moral e impulsiona a razão prática a deliberar e agir. Uma ação, por conseguinte, exprime seu agente, revela-o. Seus resultados, porém, não necessariamente correspondem à virtude ou vício daquele que age. Um homem virtuoso pode ter-se esmerado no cálculo para atingir o verdadeiro bem, mas, "por circunstâncias alheias a sua vontade", como diz o Código Civil, ter ocasionado um resultado danoso, para si ou para outrem. Vimos no capítulo 1 que falhas informacionais ou interferências de outras séries causais podem afastar a responsabilidade do agente. Nesse caso, não é que estejamos propriamente diante de uma violação à autonomia da vontade, diante de uma "coação", em algum sentido muito amplo e pouco comum da palavra. É que o resultado não correspondeu ao desejo do agente e, assim, não revelou sua personalidade. O exemplo do virtuoso que, agindo com toda diligência e cuidado, termina por matar alguém é o exemplo por excelência. A responsabilização, nesse caso, não tem justificativa, pois não serviria para moldar o caráter do agente através da sanção. O mesmo vale para a coação ou o dolo. Responsabilização e sanção seriam sinônimos, nesse caso, de injustiça.

O contexto prático também pode excluir os efeitos jurídicos da deliberação. $\mathrm{O}$ incapaz, por ainda não ter seu caráter formado, por ainda não se poder supor que tenha a prudência devidamente desenvolvida, não pode ser responsabilizado. Seu responsável legal, sim, pois o virtuoso cuida e vigia aqueles a quem deve cuidar. Se não o fez, agiu no mínimo com negligência, justificando-se a sanção, inclusive na modalidade objetiva (Código Civil, art. 932 e seus incisos), mesmo porque não seria justo, como se verá, que a vítima arque com o prejuízo sofrido. O estado de necessidade ou a lesão, por exemplo, como causas de anulabilidade do negócio jurídico, corresponderiam, no outro pólo da relação jurídica, a um agente que pretende obter vantagem a custas alheias. Essa "sanção", que fulmina o negócio, protegendo a parte em situação de vulnerabilidade, corrige, por meio de uma punição civil indireta, o caráter voraz do ganancioso. E assim por diante. Chegamos a um direito que promove e protege o virtuoso e a virtude.

Já nessa primeira leitura das normas de Direito Privado este passa a revelar-se como um sistema ético, como os preceitos objetivos de uma "ética da virtude". Afinal, o agente sempre responde por sua conduta, pois esta denuncia seu caráter. Só quando as circunstâncias revelam que o resultado não correspondeu ao desejado pelo agente — por ignorância ou por alguma forma de intimidação —, ou seja, que não exprimiu seu caráter, é que não 
será nem necessário, nem sensato castigá-lo. As normas do Direito Privado que afastam a responsabilidade, ao mesmo tempo que prevêem padrões de conduta, compõem um contexto em que, de um lado, se estipula um padrão ético a ser seguido pelo agente (para sairmos do Direito Civil: basta vermos os arts. 116 e 117 da Lei das Sociedades por Ações, Lei n. 6.404, de 15 de dezembro de 1976, que estabelecem os direitos e responsabilidades do acionista controlador da companhia), de outro lhe impõe sanções pelo seu descumprimento. O dever, assim, deixa de ser o tipo de uma conduta para consistir na expressão lingüística do comportamento esperando de um agente virtuoso, e a sanção, a recondução do vício a seu devido caminho. Traduzido dessa maneira, o Direito Privado retrataria, para Gordley, o que se espera de um indivíduo que se pauta pela excelência individual.

\section{Justiça e aritmética}

Um indivíduo é "justo" ao ter a característica de tratar os demais "com justiça”. Nesse sentido, a justiça é uma virtude como as demais: uma predisposição a escolher um determinado curso de conduta, decorrente de ações anteriores e reiterada a cada renovação desses padrões. Uma característica subjetiva do agente que o faz, nas relações interindividuais, tratar os demais indivíduos conforme "a justiça". Esse primeiro sentido, desde Aristóteles denominado "legal" (a idéia é que é justo o que trata os demais com justiça, ou seja, aquele que tem a disposição espontânea de cumprir o direito) deve corresponder algum conteúdo, ou melhor, deve ser completado por algum conceito que esclareça o que é tratar os demais com justiça.

Essa virtude cardeal, ao contrário das três restantes, exige o outro como condição de existência. Frases como "seja justo consigo mesmo" fazem sentido no contexto terapêutico ou de livros de auto-ajuda, amiúde medíocres, mas não no da ética da virtude. Ser justo é sempre ser justo em relação a outro ser humano, já que é somente com relação a outro ser humano que é possível ser injusto. Ora, a mesma forma-padrão das demais virtudes reaparece na justiça. Numa relação interindividual (entre dois indivíduos, não entre um indivíduo e uma coletividade), deve ser possível encontrar um ponto intermediário entre dois extremos. O juiz justo, aquele que efetivamente trata com justiça, valer-se-á de uma regra que encontra a média aritmética entre o "ganho" e a "perda" colhido e sofrido, respectivamente, pelo causador do dano e pela vítima. É nesse padrão que o justo virtuoso deve espelharse nas relações com outros indivíduos. Na responsabilidade contratual, a regra é que esse ganho seja real: descumprindo o contrato, o agente aufere um lucro e a outra parte, em re- 
gra, uma perda. O ponto médio matemático entre o estado de cada um, após o dano, corresponde "justamente" à eqüidistância entre um benefício indevido e uma perda indevida. A análise de Tomás de Aquino na Suma Teológica, já que estamos tratando da "tradição aristotélica", é clara e resume as duas formas de proporção matemática, correspondentes à justiça distributiva e comutativa:

Como já se disse acima, na justiça distributiva se dá algo a uma pessoa privada, enquanto que o que é próprio da totalidade é devido à parte; o qual, certamente, será tanto maior quanto esta parte tenha maior relevo no todo. Por isso, na justiça distributiva se dá a uma pessoa tanto mais dos bens comuns quanto mais preponderância tem essa pessoa na comunidade. Essa preponderância se determina na comunidade aristocrática pela virtude; na oligárquica, pelas riquezas; na democrática, pela liberdade e, em outras, de outra forma. Daí que na justiça distributiva não se determine o meio segundo a igualdade de coisa a coisa, mas sim segundo a proporção das coisas com as pessoas, de tal sorte que na medida em que uma pessoa excede a outra, assim também a coisa que seja dada a essa pessoa exceda a que se deu à outra. E por isso diz o Filósofo 5 [ou seja, Aristóteles na Ética a Nicômaco] que tal meio é segundo a proporcionalidade geométrica, na qual a igualdade se estabelece nãos egundo a quantidade, mas segundo a proporção. Como se disséssemos que assim como seis está para quatro, assim três está para dois, porque em ambos os lugares se tem uma proporcao sesquiáltera, na qual o número maior contem inteiro o menor e sua metade; mas não há igualdade de excesso segundo a quantidade, já que seis excede a quatro em dois. Em contrapartida, três excede a dois em um.

Mas nas trocas se dá algo a uma pessoa particular em razão da coisa dessa pessoa que se recebeu, como, sobretudo, se manifesta na compra e venda, na qual se encontra primeiramente a noção de troca. Por isso é preciso igualar coisa a coisa, de modo que o quanto este tenha mais do que o seu, outro tanto restituirá àquele a quem pertence. $\mathrm{E}$ desse modo se realiza a igualdade segundo a média aritmética, que se determina segundo um excedente quantitativo igual. Assim, o número 5 é o ponto médio entre 6 e 4 , pois excede e é excedido na metade. Pois se no princípio ambas as partes tinham 5, e uma delas recebe 1 do que é próprio da outra, uma, ou seja, a que recebe, terá 6 e para a outra ficarão 4. haverá, portanto, justiça se se reduz a ambas o termo médio, de modo que se tire 1 da que tinha 6 e seja dado àquela que tem 4. Pois, desse modo, terá cada uma 5, que é o ponto médio. ${ }^{71}$

No caso da responsabilidade extracontratual, o ganho é fictício, corresponde àquilo que a outra parte perdeu e o causador do dano não lhe pretende reparar. Seu lucro, portanto, está nessa omissão em pretender indenizar a vítima, que sofreu prejuízo de facto, enquanto que o causador aufere lucro de jure. Também aqui o ponto médio entre ambos os estados, sem que nem a vítima seja reparada a mais, nem o causador do dano repare de menos (princípio da restitutio in integrum, restituição integral das partes ao estado anterior) permite reparar o dano. A justiça, aqui, é comutativa e reparadora: corrige o dano e permu-

\footnotetext{
${ }^{71}$ Tomás de Aquino, Suma de Teologia, op. cit., q. 61, a. 2., p. 512-513.
} 
ta o estado das partes.

Se essa for a chave ética do Direito Privado, será preciso ser possível decodificar institutos como juros moratórios, multa contratual, etc. a partir dela. Tais figuras devem corresponder, em última instância, a uma proteção legal, de um lado, e a uma sanção, de outro. Os juros moratórios não são difíceis de explicar, e a Escolástica Tardia dos séculos XVI e XVII sugeriu concebê-los como a indenização (a etimologia, que em geral apenas desnorteia, aqui ajuda: tornar "sem dano", indene) pelo transcurso do tempo. ${ }^{72}$ Se a parte receberia, no momento aprazado, uma determinada quantia (ou coisa com valor monetário), mas a parte contrária descumpre o contrato e não a paga, presume-se que a parte que suporta o dano poderia investir o dinheiro, ou ainda que lhe fará falta. Veja-se que se a quantia ou coisa vier a ser entregue posteriormente, a violação ao princípio da justiça estará evidente, pois a parte contrária se terá beneficiado a custas da lesada. A multa contratual, com natureza ora sancionatória, ora de antecipação de indenização pelas perdas e danos, também pode ser facilmente interpretada nos mesmos parâmetros conceituais (art. 408 do Código Civil).

As principais regras previstas na Teoria das Obrigações e nos Direitos Reais, apostase então, passariam a ser traduzidas nesses termos. Se cabe o dever de transparência ao vendedor, pois revelará sua torpeza se pretender esconder o vício oculto do comprador (art. 443 do Código Civil), também, por outro lado, uma vez posta à disposição do comprador a coisa sem vício, cessa o dever de cuidado e a responsabilidade do vendedor, já que cabe ao comprador diligente zelar por sua propriedade, deixando o devedor de responder por culpa na hipótese de perecimento da coisa (art. 234). Se o adquirente estava de boa-fé — ou seja, se desconhecia o vício da coisa, se havia uma falha informacional que afastava uma conduta manifestando a torpeza —, ainda que sofra a evicção, terá direito à indenização pelas

\footnotetext{
${ }^{72}$ A título de curiosidade, a construção de Domingo de Soto no De Justitia et Jure, para poder manter tanto a rejeição da usura (entendida como cobrança de juros sobre o dinheiro emprestado) quanto sua possibilidade nos negócios (estamos em pleno século XVI, ou seja, no chamado "Século de Ouro" espanhol, em pleno apogeu da expansão marítima e comercial), consiste justamente em entendê-los, seja como uma "participação num montepio" ou numa "sociedade", seja como indenização pelo uso do dinheiro no tempo. É fascinante verificar como a reinterpretação e a reconstrução se dá a partir das ferramentas argumentativas disponíveis para os escolásticos daquela época: sem sair do quadro categorial e da férrea imagem do homem virtuoso tomista, desenvolve-se até mesmo uma teoria bancária. $\mathrm{O}$ mesmo fenômeno aconteceu no Direito Muçulmano, que também veda expressamente a usura: tiveram de ser criados mecanismos de escape dentro da própria prática jurídica. A esse respeito, vejam-se Jesús Huerta de Soto, "La teoría bancaria en la Escuela de Salamanca" (La Ilustración Liberal, 11 (2002)), p. 158167 e Reza Azarian, "Outline of an Economic Sociology of Islamic Banking" (International Journal of Business and Social Science, 17 (2008)), p. 258-268.
} 
benfeitorias (art. 453). Obviamente que, uma vez que venha a ter ciência dessa informação, se assumir o risco, só teria direito à indenização pelas benfeitorias necessárias, já que o legítimo proprietário não pode enriquecer-se à suas custas (constate-se novamente a proporção aritmética em ação ao construir tais normas).

Nem expressão de regras que estabelecem os limites entre as esferas de liberdade, nem instrumentos que são ou deveriam ser propiciadores da eficiência: as regras que compõe o direito que disciplina as relações patrimoniais entre particulares constituem um sistema jurídico cuja consistência provém de um vértice, onde se encontra o retrato de um indivíduo virtuoso. Agir conforme uma ética da virtude é agir conforme as regras do Direito Privado, seja porque estas a exprimem, seja porque são aquelas que são suficientes para o juízo moral.

\section{O cânone antipódico}

Normas de Direito Privado impõem deveres, mas de modo geral prevêem condutas e atribuem sanções pelo seu descumprimento. "Responde" é a palavra-chave que traduz a punição, mas também o dever de restituir as partes ao estado de equilíbrio. "Nos contratos onerosos, o alienante responde pela evicção" (art. 447 do Código Civil). "Aquele que tiver prometido fato de terceiro responderá por perdas e danos, quando este o não executar" (art. 439). "O devedor em mora responde pela impossibilidade da prestação, embora essa impossibilidade resulte de caso fortuito ou de força maior, se estes ocorrerem durante o atraso; salvo se provar isenção de culpa, ou que o dano sobreviria ainda quando a obrigação fosse oportunamente desempenhada" (art. 399). "Responde o devedor pelos prejuízos a que sua mora der causa, mais juros, atualização dos valores monetários segundo índices oficiais regularmente estabelecidos, e honorários de advogado" (art. 395). "O acionista responde pelos danos causados pelo exercício abusivo do direito de voto, ainda que seu voto não haja prevalecido"; "A deliberação tomada em decorrência do voto de acionista que tem interesse conflitante com o da companhia é anulável; o acionista responderá pelos danos causados e será obrigado a transferir para a companhia as vantagens que tiver auferido" (art. 115, $\S \S 3 .^{\circ}$ e $4 .^{\circ}$ da Lei das Sociedades por Ações). “Os membros do conselho fiscal têm os mesmos deveres dos administradores de que tratam os arts. 153 a 156 e respondem pelos danos resultantes de omissão no cumprimento de seus deveres e de atos praticados com culpa ou dolo, ou com violação da lei ou do estatuto" (art. 165 da Lei das Sociedades por Ações). 
"Responder" corresponde a "dever", porém pelo revés. A descrição de uma sanção pelo descumprimento de uma conduta equivale, vista pelo avesso, à imposição de um dever legal. A operação lógica é bem conhecida desde o Positivismo Clássico no século XIX: a todo dever corresponde uma sanção, expressa ou indireta, pela proteção judicial. A expressão "responde", porém, no Direito Privado (não no Direito Penal, onde há a previsão de tipos penais de mera conduta, puníveis sem que haja dano, de discutível constitucionalidade, segundo os penalistas), encontra-se sempre associada a um dano: responder por perdas e danos. Como vimos no item anterior, nem sempre, porém, o dever legal corresponde diretamente ao avesso de um dano. Razões jurídicas podem ser suficientes para a deliberação prática pelo simples fato de estarem previstas, e a conduta virtuosa será aquela que, independentemente de evitar ou não um dano, pretende conferir eficácia prática ao que está previsto legalmente.

No entanto, tomando nas mãos o Direito Privado e voltando-o para vê-lo por detrás, o que se encontraria seria a narrativa do comportamento de um indivíduo virtuoso. Ele é diligente, autocontrolado, zeloso e detalhista, mas não indeciso. Cuida de seu patrimônio tanto quanto evita danos a terceiros. Se os causa, indeniza-os imediatamente. Cumpre com a palavra acordada, no prazo e da forma como foi estipulado. É parcimonioso, econômico, precavido. Administra interesses de terceiros tal como os seus, com esmero e afinco. O Direito Privado, encarado a partir de seu sistema de deveres, revela a figura do indivíduo probo e ativo da "tradição aristotélica".

O método, como se vê, abre o caminho do direito a suas "condições de possibilidade". Com isso se evitariam, supostamente, as objeções filosóficas tradicionais — totalmente desconhecidas no campo da dogmática jurídica, cuja densidade filosófica, como bem sabemos, é bem rala - de que se estaria tentando fundamentar o Direito Privado numa teoria metafísica da natureza humana, de seu desenvolvimento até atingir o cume do indivíduo plenamente formado física, intelectual e moralmente, e de uma ontologia essencialista e finalista.

Essa desconfiança, porém, é menos importante, por mais surpreendente que isso pareça, do que o fato de que a imagem do indivíduo virtuoso traça um retrato que é, desde o início, expressamente interindividual (entre indivíduos, ainda abstratos, mesmo que tingidos com as cores fortes de uma "teoria da virtude"). As normas de Direito Privado não traçam, por óbvio, limites à liberdade no momento mesmo em que alçam o indivíduo a sua autonomia e, portanto, a sua própria liberdade. Mas menos ainda estariam preocupadas 
com a distribuição social eficiente da riqueza, para satisfazer ao máximo a todos. A justiça é uma virtude, o sistema do Direito Privado é seu corolário, mas atinge apenas relações entre indivíduos. Ele parte, ou antes, pressupõe que os indivíduos, apesar da complexidade dos contextos práticos em que agem, se encontram em situação de igualdade. Se não se encontram, caberá ao Estado - a políticas públicas redistributivas, de modo mais geral (progressividade tributária, serviços sociais, serviços públicos essenciais, política de crédito subsidiário ou renúncia fiscal, políticas de proteção social, fundos constitucionais de participação dos Estados e Municípios, entre inúmeros outros instrumentos legais possíveis) —, ou seja, ao Direito Público, recolocá-los em situação de igualdade. A concentração da riqueza, se for considerada um mal, não deve ser corrigida pelo Direito Privado, expressão jurídica de uma ética da virtude.

Isso não quer dizer que o Estado não possa, se achar conveniente para proteger a justiça como virtude, interferir na liberdade contratual. A regra não é essa: a distribuição de riqueza deve dar-se por uma ação do Estado que não passa pela interferência nas relações privadas. Esse retrato do homem virtuoso admite a intervenção estatal, mas, se interferência há, não é para alcançar uma distribuição mais justa, mas para proteger os "bons cidadãos":

Uma conclusão a que chegamos é que, esteja ou não alguém vivendo numa sociedade democrática, o Estado não precisa agir paternalisticamente quando influencia ou interfere com os contratos nos quais ingressam seus cidadãos. Pode meramente estar fazendo justiça distributiva ou comutativa. O caminho normal para um governo operar é promover uma partilha justa do poder de compra para seus cidadãos, e então deixá-los livres, enquanto estiverem agindo honestamente, para ganhar e gastar como eles acharem conveniente. É por isso que este ensaio não se preocupou com tais esforços para promover igualdade como a estipulação de um salário mínimo ou com tais doutrinas contratuais como a teoria da imprevisão para impedir injustiças [unconscionability to prevent unfairness]. Tais medidas são freqüentemente caracterizadas como paternalistas, mas não são, no nosso sentido, quando são usados exclusivamente para fazer justiça. Em contraste, o Estado realmente age paternalisticamente quando se opõe aos contratos nos quais os cidadãos ingressam para ganhar ou gastar porque pensa que eles escolheram erroneamente. $^{73}$

Resta saber se, para além das relações jurídicas verticais (indivíduo-Estado), a disciplina das relações jurídicas horizontais (entre indivíduos) também não se revelaria, após alguns testes, também um mecanismo de distribuição de riqueza — ou antes, um sistema de di-

${ }^{73}$ James Gordley, "Morality and Contract: The Question of Paternalism" (William \& Mary Law Review 48 (2007)), p. 1770. 
ques e barragens para conter sua transferência a priori, antes mesmo da atuação, a posteriori, dos mecanismos de redistribuição do Estado. A questão não é política: é hermenêutica. Se o Código Civil ou o Código de Proteção e Defesa do Consumidor, se o Direito Societário ou a disciplina dos Títulos de Crédito puderem ser entendidos como artifícios que, ao aparentarem efetivar uma determinada regra de justiça (a comutatividade), na realidade conteriam a transferência de riqueza entre grupos de indivíduos no ambiente de mercado, tanto sua natureza última quanto sua unidade e interpretação traçariam um retrato inusitado do Direito Privado.

As três imagens-narrativas anteriores deverão admitir um último conviva. Estamos, por fim, diante do retrato do homem desigual. 


\section{Capítulo 4:}

\section{O Retrato dos Homens Desiguais}

\section{Deslocamentos}

As imagens acima não enfrentam, ou antes contornam, a figura da desigualdade. Seu reconhecimento, vacilante e nunca frente a frente (e isso é um sintoma revelador), pela dogmática iniciou-se no final do século XIX e se tornou inevitável no século XX. ${ }^{74}$ Há várias razões para tanto. A análise jurídica das operações econômicas — friso bem: jurídica — está habituada a decompô-las de maneira fragmentária e atomizada. Este negócio jurídico é nulo, porque o objeto é ilícito. Este outro é anulável, pois uma das partes o celebrou sob coação. Aqui a parte não responde pelo dano, pois agiu dentro dos estritos limites de um direito reconhecido. Mas ali já não, pois agiu com abuso de direito. Ele se enriqueceu ilicitamente a custas do outro, logo, deve indenizá-lo. Já este aqui, não, pois seu enriquecimento possui uma causa jurídica que o justifica. E assim por diante. O Processo Civil, contrapartida jurisdicional a serviço essencialmente do Direito Privado, produz e reproduz a fragmentação atomizada das relações jurídicas, agora entendidas como "conflito".

A visão é, portanto, fracionada, segmentada, particularizada. E a regra de justiça que

\footnotetext{
${ }^{74}$ Veja-se, a esse respeito, novamente Caio Mário da Silva Pereira, Instituições, op. cit., vol. I, p. 14: “A influência absorvente do Estado e a necessidade de se instituírem, com mais segurança e amplitude, fórmulas cada vez mais dirigidas no sentido de realizar a finalidade precípua do direito que se positiva e se afirma no propósito de garantir e proteger o bem-estar do indivíduo in concreto, cogitando da normação social em atenção ao bem da pessoa, geram a tendência à publicização da norma jurídica. [...] $\mathrm{O}$ contrato, antes expressão maior da autonomia da vontade, sofre interferências a beneficio do economicamente inferior." (grifamos).
} 
corresponderia a cada uma dessas relações jurídicas é, como sustenta o neoaristotelismo, uma regra que procura proteger as partes, recolocando-as no estado em que estariam se a violação não tivesse acontecido. A restititutio in integrum é a outra face da reposição ao statu quo ante, ao estado anterior ao dano indenizável (novamente: "indene”, ou seja, "sem dano"). Tudo se passa como se o direito tivesse por função suprimir, remover a patologia, apagar o passado, ou, visto pelo contrário, impedir que ocorresse. Daí que a justiça seja corretiva, "reparatória", corrija o desacerto, e as regras que presidem os principais institutos do Direito Privado, mecanismos para assegurar expectativas.

Visto por esse ângulo — "analítico", digamos assim, ou seja, decompositivo —, o Direito Privado não tem por função produzir efeitos redistributivos. Gordley, como vimos, tirou as conseqüências últimas e de maneira rigorosa. Na melhor das hipóteses, como apostarão as análises econômicas do direito, ele deve servir para propiciar a maximização possível da riqueza, que corresponderá sempre a satisfazer o máximo possível as preferências por meio de um ambiente de mercado eficiente. A distribuição da riqueza, portanto, é irrelevante: seja porque o Direito Privado deve mesmo é proteger reciprocamente as esferas de autonomia individual, ou seja, de liberdade. Seja porque a distribuição social da riqueza é apenas um fenômeno curioso, a ser estudado, sem dúvida, mas que nunca pode pôr-se à frente da eficiência e maximização da riqueza (permanecer aquém, ainda que numa distribuição mais justa, equivaleria a frustrar preferências que, de outro modo, poderiam ser satisfeitas). $\mathrm{Ou}$, finalmente, seja porque lhe cabe reparar, corrigir o desvio, patrocinar a justiça como virtude que reflete o comedimento individual e a confiabilidade das relações sociais. Neste último caso, se houver preocupação com a distribuição da riqueza (e para a "tradição aristotélica", como vimos, há), cabe ao Estado, ao "Direito Público", encarregar-se do problema, não ao Direito Privado, pois é a ele que se deve reclamar a aplicação de uma outra virtude, a justiça na forma "distributiva". Se houver proteção à vulnerabilidade, esta deve ocorrer apenas nos casos de evidente desequilíbrio que atingem o próprio sistema de virtudes (como no caso do estado de necessidade ou da lesão). De resto, o Direito Privado não se preocupa com ela. Não deve ser — como gostam de dizer — "paternalista".

Para a análise que vê o Direito Privado como um instrumento legal a serviço da redistribuição da riqueza, porém, uma operação metodológica revelaria que esse ramo normativo não é nem deve ser tão isenta e neutra quanto pretende ser. A operação consiste em recuperar das análises econômicas do direito o conceito de custo de transação, de um lado, e verificar, de modo agregado, o que ocorreria se a regra dispusesse de maneira diferente, 
de outro. Tirando as conseqüências últimas da regra da justiça comutativa, verificaremos que toda vez que há descumprimento da palavra avençada ou do dano decorrente de um ato ilícito extracontratual, uma parte lucra, seja porque é beneficiada, seja porque deixa de indenizar. De modo geral: toda vez que há violação ao princípio social (não individual, notese) da confiança, seja porque o contrato deixou de ser cumprido (e se confiava no seu cumprimento), seja porque alguém causou dano e não o indenizou (e se confia que socialmente os indivíduos não lesarão uns aos outros), seja porque, de modo mais geral, alguém se enriqueceu à custa de outro sem que houvesse causa jurídica que o legitimasse (e se confia que o enriquecimento tenha sempre uma causa juridicamente legítima), uma parte $l u$ crou e outra perdeu. Houve, assim, deslocamento (absoluto ou relativo) de riqueza de uma parte para a outra.

Não é suficiente, porém, interrompermos o percurso por aqui. A banalidade de que alguém lucra, aumentando seu patrimônio ou deixando de diminuí-lo, quando viola uma norma de Direito Privado cuja função é corrigir, reparar o dano causado, havia sido filosoficamente desenvolvida, como vimos, desde a Ética a Nicômaco até o neoaristotelismo. Seria preciso, porém, dar um passo a mais e explorar, de modo agregado, repita-se, qual seria o efeito socioeconômico da inexistência da regra ou de sua violação sistemática. Não se trata de verificar se a regra que impõe a indenização pelo dano causado ou o dever de informar o comprador do vício oculto da coisa é eficiente ou não. O objetivo é outro: trata-se de investigar como tais regras, ao presidirem operações jurídico-econômicas, permitem ou bloqueiam o deslocamento de riqueza entre grupos de indivíduos na sociedade. O resultado final seria, claro, uma teoria da justiça "distributiva", um retrato do que se espera que seja a distribuição justa da riqueza social, e que exigirá seu fundamento numa teoria mais ampla da "justiça social" (entre aspas, é óbvio). Dessa forma, surpreendentemente, o fundamento do Direito Privado passa a ser não mais a autonomia, a preferência maximalmente satisfeita ou a virtude, mas antes a própria teoria da justiça distributiva que reconhece que os indivíduos estão desiguais e são repostos em desigualdade.

Desenvolvamos o raciocínio e a narrativa que ela constrói, agora pela última vez.

\section{Transferindo e concentrando}

Tomemos uma regra singela como aquela que impõe o dever do credor de informar 
acerca dos vícios redibitórios da coisa. ${ }^{75}$ A regra, que preside os contratos comutativos de toda espécie, é comum às famílias jurídicas inglesa e romanística. Ela está presente no art. 441 do nosso Código Civil e dispõe que: "A coisa recebida em virtude de contrato comutativo pode ser enjeitada por vícios ou defeitos ocultos, que a tornem imprópria ao uso a que é destinada, ou lhe diminuam o valor". Ela se completa com aquela do art. 443 do Código Civil: "Se o alienante conhecia o vício ou defeito da coisa, restituirá o que recebeu com perdas e danos; se o não conhecia, tão-somente restituirá o valor recebido, mais as despesas do contrato". Fixemos a atenção por instantes na forma e no conteúdo desses dispositivos, chamando à mesa de trabalho a análise doutrinária clássica:

Segundo o que se deduz da norma legal, e dos princípios doutrinários assentes, alinhamse alguns requisitos de verificação dos vícios redibitórios, a saber:

A - Os defeitos devem ser ocultos, pois que os ostensivos, pelo fato de o serem, se presumem levados em consideração pelo adquirente, que não enjeitou mas recebeu a coisa. A verificação deste requisito é às vezes difícil na prática, já que um defeito pode ser oculto para uma pessoa e perceptível facilmente para outra. A apuração far-se-á, entretanto, in abstracto, considerando-se oculto o defeito que uma pessoa, que disponha dos conhecimentos técnicos do adquirente, ou que uma pessoa de diligência média, se não for um técnico, possa descobrir a um exame elementar. Não se reputa oculto o defeito somente porque o adquirente o não enxergou, visto como a negligência não merece proteção.

B - Deverão ser desconhecidos do adquirente; se deles tiver conhecimento, mesmo que não sejam aparentes, não se pode queixar de sua presença.

${ }^{75}$ A dogmática civilista "controverte" a respeito da "natureza jurídica" desse instituto:

"Não se aproxima ontologicamente o conceito de vício redibitório da idéia de responsabilidade civil. Não se deixa perturbar a sua noção com a indagação da conduta do contratante, ou apuração da sua culpa, que influirá contudo na graduação dos respectivos efeitos, sem aparecer como elemento de sua caracterização. $\mathrm{O}$ erro tem sido apontado como seu fundamento, com o argumento de que o agente não faria o contrato se conhecesse a verdadeira situação (Carvalho de Mendonça); na teoria dos riscos vai justificá-lo Brinz; na responsabilidade do vendedor pela impossibilidade parcial da prestação, assenta-o Regelsberger; vai Windscheid ligá-lo à pressuposição; Cunha Gonçalves acha uma variante desta na inexecução do alienante: Von Ihering prende-o à eqüidade; Fubini toma em consideração a finalidade específica da prestação. Para nós, o seu fundamento é o princípio de garantia, sem a intromissão de fatores exógenos, de ordem psicológica ou moral. $\mathrm{O}$ adquirente, sujeito a uma contraprestação, tem direito à utilidade natural da coisa, e, se ela lhe falta, precisa de estar garantido contra o alienante, para a hipótese de lhe ser entregue coisa a que faltem qualidades essenciais de prestabilidade, independentemente de uma pesquisa de motivação. Por isto, Tito Fulgêncio, em síntese apertada e feliz, enuncia-o, dizendo que o alienante é, de pleno direito, garante dos vícios redibitórios. Ao transferir ao adquirente coisa de qualquer espécie, seja móvel, seja imóvel, por contrato comutativo, tem o dever de assegurar-lhe a sua posse útil, se não equivalente rigorosa, ao menos relativa do preço recebido. E, se ela não se presta à sua finalidade natural, ou se não guarda paralelismo com o valor de aquisição, prejudicada por defeito oculto, tem o adquirente o direito de exigir do transmitente a efetivação do princípio de garantia." (Caio Mário da Silva Pereira. Instituições de Direito Civil, vol. I, op. cit., p. 85). 
C - Somente se levam em conta os já existentes ao tempo da alienação e que perdurem até o momento da reclamação. Os supervenientes afetam coisa já incorporada ao patrimônio do adquirente; e se houverem cessado, deixam a demanda sem objeto.

D - Não é qualquer defeito que fundamenta o pedido de efetivação do princípio, porém aqueles que positivamente prejudicam a utilidade da coisa, tornando-a inapta às suas finalidades, ou reduzindo a sua expressão econômica. ${ }^{76}$

$\mathrm{O}$ art. 441, portanto, confere uma faculdade ao adquirente. Ele tem o direito de "enjeitar" (recusar ou rejeitar) a coisa ao se deparar com vícios ou defeitos. (Vícios atingem a qualidade, não comprometendo a segurança. O defeito, além de mais grave e incidindo sobre a própria substância da coisa, acarreta risco.) Tais qualidades são, na sistemática do Código Civil (não na do Código de Proteção e Defesa do Consumidor, frise-se ${ }^{77}$ ), necessariamente ocultas, ou seja, o adquirente da coisa não as conhecia no momento em que a adquiriu. Elas se revelaram a ele posteriormente. E não basta que sejam qualidades quaisquer, em desconformidade ao previsto no contrato (aqui estaríamos diante dos institutos do erro substancial e do erro acidental, este último não protegido juridicamente, e não da enjeição

\footnotetext{
${ }^{76}$ Caio Mário da Silva Pereira. Instituições de Direito Civil, vol. I, op. cit., p. 85-86.
}

${ }^{77}$ A diferença, e é o caso de manter a atenção sobre ela a partir de agora, encontra-se no art. 26, caput e parágrafo $3 .^{\circ}$ do Código de Proteção e Defesa do Consumidor. Esse dispositivo disciplina o instituto da decadência no Código de Proteção e Defesa do Consumidor, instituto esse que, de resto, guarda só parcial correspondência com a decadência do Código Civil (tanto que o título da seção é "Da Decadência e da Prescrição", mas logo a seguir os dispositivos passam a falar em "caducidade" e permitem, contra a sistemática civilista clássica, a suspensão - para alguns doutrinadores, interrupção - do prazo decadencial). O artigo estabelece: "Art. 26. O direito de reclamar pelos vícios aparentes ou de fácil constatação caduca em: I - trinta dias, tratando-se de fornecimento de serviço e de produtos não duráveis; II noventa dias, tratando-se de fornecimento de serviço e de produtos duráveis. $\S 1^{\circ}$ Inicia-se a contagem do prazo decadencial a partir da entrega efetiva do produto ou do término da execução dos serviços. $\S$ $2^{\circ}$ Obstam a decadência: I - a reclamação comprovadamente formulada pelo consumidor perante $o$ fornecedor de produtos e serviços até a resposta negativa correspondente, que deve ser transmitida de forma inequívoca; II - (Vetado). III - a instauração de inquérito civil, até seu encerramento. $§ 3^{\circ}$ Tratandose de vício oculto, o prazo decadencial inicia-se no momento em que ficar evidenciado o defeito." Perceba-se: o vício aparente, mesmo o de fácil constatação, enseja, na disciplina do Código de Proteção e Defesa do Consumidor, o direito à reclamação. No Código Civil, como afirma Caio Mário da Silva Pereira, "Os defeitos devem ser ocultos, pois que os ostensivos, pelo fato de o serem, se presumem levados em consideração pelo adquirente, que não enjeitou mas recebeu a coisa. [...] Não se reputa oculto o defeito somente porque o adquirente o não enxergou, visto como a negligência não merece proteção." $\mathrm{E}$ o prazo decadencial para enjeição por vício oculto se inicia, em regra, no Código Civil, a partir da entrega da coisa; no Código Civil, a regra é a partir da ciência do vício. Veja-se, a esse respeito, para que não restem dúvidas, Luis Antonio Rizzatto Nunes, Curso de direito do consumidor (7. ed. São Paulo: Saraiva, 2012), p. 429- 431; Cláudia Lima Marques. Contratos no Código de Proteção e Defesa do Consumidor: o novo regime das relações contratuais (3. ed. São Paulo: Editora Revista dos Tribunais, 1998), p. 603-614; Ada Pellegrini Grinover et alli. Código brasileiro de defesa do consumidor: comentado pelos autores do anteprojeto (Rio dc Janeiro: Forense Universitária, 1998), p. 186-188. 
por vício). É preciso que elas ou tornem a coisa "imprópria ao uso a que é destinada" - e a teoria da causa do contrato, prevista no art. 139, II do Código Civil que introduz "a identidade ou a qualidade essencial da pessoa a quem se refira a declaração de vontade, desde que tenha influído nesta de modo relevante", permite que ao lado do uso comum seja possível imaginar um uso particular por parte daquele que a adquire — ou "lhe diminuam o valor" (médio de mercado).

Examinada a norma pelo ângulo diametralmente oposto, ela impõe ao alienante um dever: o de informar acerca de todas as características da coisa e especialmente daquelas que a tornem imprópria ou lhe diminuam o valor. O art. 147 do Código Civil caracteriza a atitude como "omissão dolosa": "Nos negócios jurídicos bilaterais, o silêncio intencional de uma das partes a respeito de fato ou qualidade que a outra parte haja ignorado, constitui omissão dolosa, provando-se que sem ela o negócio não se teria celebrado". O alienante não pode deixar de informar qualquer "fato ou qualidade" que, se conhecida da parte contrária, impediriam a contratação ou alterariam seus termos. A expressão "fato ou qualidade" é ampla o suficiente para abranger não só as características da coisa (que a redibição especificará como impropriedade ou desvalorização), mas também "fato" relevante. A regra preside a totalidade do Direito Privado, como regra mínima que impõe o chamado "dever de informação". 78

O descumprimento desse dever impõe uma sanção: a) restituição do que o alienante recebeu com perdas e danos, se conhecia o vício ou defeito da coisa; b) se não o conhecia, tão-somente o valor recebido, mais as despesas do contrato. No primeiro caso, há a restituição do valor pago (se o contrato foi de compra e venda, por exemplo), acrescido de indenização por danos (o equivalente em dinheiro ao dano patrimonial sofrido pelo adquirente) e perdas (o que ele teria deixado de lucrar). Assim, eventual lucro do alienante é restituído ao adquirente, reposicionando, na linguagem da teoria da justiça comutativa, as partes ao estado em que deveriam se encontrar caso não tivesse havido o ilícito contratual. Como a ignorância da informação pelo alienante não lhe impõe o mesmo dever, não pode ser res-

\footnotetext{
${ }^{78}$ Alexandre David Malfatti, no seu O direito de informação no Código de Proteção e Defesa do Consumidor (São Paulo, Alfabeto Jurídico, 2003), apresentou um modelo analítico, a partir da teoria da comunicação, para organizar o princípio geral do direito à informação no Direito do Consumidor. O modelo, doutrinariamente elegante, permite organizar num sistema único a teoria do vício, a proteção contratual, as práticas abusivas, parte considerável da responsabilidade civil (no Código de Proteção e Defesa do Consumidor, supera-se a distinção entre contratual e extracontratual, como se sabe) e a disciplina da publicidade, a partir das falhas comunicacionais possíveis que podem nascer de um emissor, um
} 
ponsabilizado pelo dano suportado pelo adquirente, de forma que apenas restituirá o valor e mais as despesas acessórias do contrato (emolumentos, honorários advocatícios, custas com certidões, honorários periciais, etc.).

Imaginemos agora que a norma não existisse. Nesse caso, os negócios jurídicos nem por isso deixariam de ser realizados, mas imporiam um custo adicional e a assunção de um risco aos adquirentes que também influiria na fixação de seu preço. Na aquisição de qualquer objeto ou o adquirente seria forçado a arcar com custos de perícias, mais ou menos complexas, para identificar a qualidade da coisa adquirida, transferindo sua riqueza para terceiros, ou ainda teria de arcar com o risco da coisa apresentar vício ou defeito sem que lhe fosse garantida a redibição e suas conseqüências patrimoniais, o que também corresponderia a uma transferência de riqueza para o alienante e eventuais terceiros (em contratos coligados de seguro, por exemplo). Ainda que se imagine que um mercado de concorrência perfeita equilibrasse custos com a avaliação das características da coisa e riscos assumidos pelo adquirente, de um lado, e preço de aquisição, de outro, um mercado com tais características não só é raro, como não impediria que a riqueza se deslocasse do adquirente para o alienante. E essa resposta do "paretianismo" contrabandeia ainda várias outras dificuldades:

Claro que o princípio do paretianismo nem sempre oferece uma resposta tão clara como tais casos podem sugerir. Suponhamos, por exemplo, que A está ciente de um vício importante em sua própria propriedade - uma infestação de cupins, digamos - e apenas deixa de informar B da presença do vício. A seguramente está explorando sua superioridade informacional às custas de $\mathrm{B}$. Quanto a isso, a conduta de $\mathrm{A}$ é indistinguível daquela de B na situação descrita anteriormente - quando B se oferecia para comprar a propriedade de A sem revelar o que ele sabia sobre seu real valor. Além disso, a informação de A, como a de B, é produtiva por natureza, porque revela um fato que deve ser tomado em consideração se a alocação de recursos escassos deve ser tão eficiente quanto possível. Diferentemente da informação de B, no entanto, o conhecimento de A quanto aos cupins pode ser o resultado de observações casuais feitas enquanto vivia na casa em vez de o resultado de uma pesquisa deliberada e cara. Sendo assim, uma regra que requer que A revele o que sabe sobre os cupins não terá nenhum efeito, ou terá só um pequeno efeito, sobre a produção dessa informação. Além disso, uma regra dessa espécie reduzirá os próprios custos de inspeção de $\mathrm{B}$ - que provavelmente serão maiores do que os de A, dada a não familiaridade de $\mathrm{B}$ com a propriedade. Admitindo que a maior parte das pessoas serão adquirentes num número de vezes aproximadamente igual ao que serão vendedores, pode-se talvez concluir provisoriamente que seus ganhos decorrentes de uma norma legal que requer que os vendedores revelem os vícios substanciais e invisíveis excederão as perdas ocasionais que sofrerão como resultado dela. ${ }^{79}$

receptor e da própria mensagem.

${ }^{79}$ Veja-se, a esse respeito, Anthony Kronman, "Contract Law and Distributive Justice" (Yale Law Jour- 
Observando, assim, o conjunto de negócios jurídicos, de maneira agregada, que seriam realizados na ausência dessa norma, verificaremos uma transferência, um deslocamento de riqueza de um grupo de indivíduos - os adquirentes - para outro grupo de indivíduos os alienantes. Sua falta no sistema jurídico acarreta concentração de riqueza em um grupo e transferência de outro grupo. Seria possível, portanto, para além de uma análise que se concentra na maximização da riqueza e na eficiência alocativa, examinar as normas de Direito Privado pelo foco não mais da justiça comutativa, mas da justiça distributiva.

\section{Bombeamento vertical}

As teorias tradicionais da justiça distributiva - especialmente a de Rawls, mas também a Sen — apoiaram-se no Estado como instrumento de políticas redistributivas. Se a redistribuição da riqueza deve ser realizada, recuperando uma distribuição mais igual (conforme algum critério, sendo esta a principal controvérsia das teorias, para além de seus “fundamentos últimos"), esta deve ocorrer a posteriori. Dito de outra forma, um mercado eficiente seria manifestamente concentrador. A maximização da riqueza acarretaria inevitavelmente distribuição desigual de recursos sociais como preço (alto) a pagar. Se o que se pretende é que um sistema econômico funcione na máxima intensidade, e não aquém disso (pois o máximo, ou seja, um passo além do "aquém do máximo", equivale a dizer que ao menos uma preferência a mais será satisfeita), o resultado será sempre um perfil de distribuição de riqueza desigual. ${ }^{80}$

Mesmo que se deixe de lado a análise focalizada exclusivamente no equilíbrio econômico, passando a análises que destacam a evolução histórica da concentração de renda e suas origens numa distribuição inicial desigual (por exemplo, os efeitos históricos de longo prazo da instituição da escravidão), ainda assim o principal instrumento, e supostamente o mais eficiente, para a redistribuição da riqueza seria a ação estatal incidente após ela se ter

nal 1980), p. 491.

${ }^{80}$ Há quem sustente que redistribuição é um objetivo que deve conviver também com eficiência. Se se admitir a existência de uma pluralidade de mercados, pode-se conceber que, em alguns, a eficiência seja um valor a ser alcançado e não a redistribuição, valor prioritário em outros mercados. Essa objeção, porém, não alcança a teoria distributivista do Direito Privado. Sua tese não é que não se possa conceber a existência de uma multiplicidade de mercados, cada um com características tais que o direito devesse tratá-los de maneira diversa, mas antes que o Direito Privado pode ser lido como um conjunto de instrumentos normativos que regularia o deslocamento da riqueza. Não percamos, porém, o foco da análi- 
concentrado. O mecanismo, portanto, é a posteriori, ocorre após sua condensação em poder de um grupo ou classe social, não antes. E para tanto é criada uma profusão de mecanismos estatais que visam, bem ou mal, recompor produzir uma ordem social economicamente mais "justa".

Alguns exemplos nacionais podem ser lembrados. O sistema tributário é o primeiro deles, já no início do mecanismo estatal de distribuição. A progressividade do Imposto de Renda ou do Imposto Predial e Territorial Urbano, por exemplo, imporia aos indivíduos mais ricos uma participação maior na contribuição do que aos mais pobres. Isenções tributárias seriam outro mecanismo ainda nesse campo, a exemplo, também, das contribuições sociais, que têm destinação específica e transfeririam diretamente riqueza de um conjunto de indivíduos para o custeio de serviços prestados pelo Estado especialmente para os mais pobres. Contribuições como a Cofins (Contribuição para o Financiamento da Seguridade Social) e a CSLL (Contribuição sobre o Lucro Líquido) — que financiam a seguridade social e incidem respectivamente sobre a "receita bruta total" e o "lucro líquido" —, são um exemplos típicos desse sistema compulsório de transferência de riqueza pela via tributária. $\mathrm{Na}$ outra ponta encontraríamos a prestação de serviços públicos uti universi pelo Estado, que, embora juridicamente disponíveis para todos (ainda que condicionada sua prestação), na prática, beneficiaria aqueles indivíduos situados na base da pirâmide de distribuição social da riqueza (saúde, educação, construção de habitações populares, subsídio ao transporte coletivo, financiamento da seguridade social, etc.). A distribuição poderia alcançar até mesmo a estrutura constitucional do Direito Financeiro, com a previsão de fundos de participação de Estados e Municípios, tratamento privilegiado de regiões menos desenvolvidas ou destinação imediata de porcentuais de certos tributos aos entes federados. ${ }^{81}$

O mecanismo vertical (do indivíduo com o Estado, que se situa, por assim dizer, "acima" da sociedade) consiste, portanto, na construção jurídica de um sistema de bombeamento de renda e riqueza. Bombeia-se renda de um reservatório, onde se concentrou, para outro reservatório, onde se encontra escassa: do grupo social que concentra renda para aquele outro grupo social com menor densidade. À parte as dificuldades políticas, que não

se, que é fazer emergir a imagem-narrativa que o exame da teoria permite fazer emergir.

${ }^{81}$ Entre inúmeros outros, vejam-se os arts. 157 a 162 (repartição de receitas tributárias entre os entes federativos, seja com participação direta na receita arrecadada de tributos de competência de outros entes, seja pela constituição de fundos de participação) e art. 151, II (tratamento tributário diferenciado entre as regiões com vista a a promover o equilíbrio do desenvolvimento sócio-econômico) todos da Constituição Federal. 
nos interessam aqui, as teorias da justiça distributiva - ainda de matriz liberal, como se percebe - devem oferecer critérios e "padrões de legitimidade" para justificar não só os mecanismos, mas para o próprio conteúdo particular dessas políticas redistributivas. Não só justificar por que é necessário redistribuir posições sociais e riqueza entre os indivíduos, especialmente quando os modelos econômicos neoclássicos desautorizam esse procedimento (novamente: uma melhor distribuição equivaleria a não atingir o máximo ideal e, portanto, alguma preferência ver-se insatisfeita, quando poderia tê-lo sido), mas também fornecer um critério de julgamento dos perfis de distribuição social e propor políticas de atuação do Estado.

O primeiro mecanismo, portanto, de realocação de riqueza é, em síntese, essencialmente tributário:

Será útil começar contrastando dois diferentes métodos para redistribuir riqueza. Um é a tributação. Para ilustrar como a tributação funciona, admita que a cada indivíduo na sociedade é dada sua parcela equânime dos recursos sociais e então liberado para negociar com outros em quaisquer termos que preferir. A atribuição inicial de parcelas necessariamente se conformará a um padrão de alguma espécie, o próprio padrão dependendo da teoria da justiça distributiva de cada um. Com o tempo, contudo, o padrão geral de suas posses individuais é obrigado a divergir do padrão original ideal. Tal como tanto críticos e defensores do liberalismo apontaram, essa divergência é a conseqüência indesejada de inúmeras transações privadas entre diferentes indivíduos, todos eles tentando fazer avançar seu autointeresse de modos legítimos. Contudo, quando a distribuição de posses individuais é inconsistente com o princípio do merecimento subjacente à distribuição original da riqueza, deve ser modificada pela redistribuição corretiva. Se a tributação é adotada como método de redistribuição, se exigirá dos que agora têm mais do que merecem que façam um pagamento apropriado ao Estado e que os fundos coletados dessa maneira sejam transferidos àqueles cujas posses são injustamente pequenas. Dessa maneira, o padrão original de posses pode ser restabelecido, e a justiça distributiva, preservada. ${ }^{82}$

Essa teoria não conflitaria, à primeira vista ao menos, com uma visão do Direito Privado como manifestação normativa da justiça comutativa. Aqui, tudo se passa como se o Direito Privado pertencesse a uma esfera inteiramente alheia e não lhe coubesse decidir sobre a distribuição de riqueza. Ele disciplinaria justamente aquelas operações econômicas que podem acarretar a concentração, que, por sua vez, deverá ser "corrigida" pela ação distributiva do Estado. A justiça distributiva, por conseguinte, constituiria um outro critério de justiça, diverso e de natureza diferente, que não se oporia, mas também não influiria na justiça comutativa e na profusão de regras específicas que dela derivariam. Com a mesma irrelevância, mas com certas ponderações, ela seria tratada por uma concepção neokantia-

${ }^{82}$ Anthony Kronman, “Contract Law and Distributive Justice”, op. cit., p. 499. 
na, que as vê como a expressão dos limites recíprocos das esferas de liberdade individual. Se o Estado deseja redistribuir riqueza, desde que respeite os limites éticos da autonomia individual, ou seja, desde que ele próprio seja o fiador dessas regras, não haveria nada a objetar. A atuação do Estado, naturalmente, tem limites - no critério legitimador daquela distribuição inicial considerada "equânime" — e não é preciso ir muito longe para imaginá-los, se o que caracteriza o indivíduo como tal é a possibilidade de autodeterminar-se racionalmente na esfera moral. Quanto a uma análise econômica, a resposta é evidente.

Nem toda forma de redistribuição, enfim, é vertical. A existência de fundos financiados com a participação dos próprios beneficiados é uma prova disso. A previdência social, por exemplo, embora seja financiada por contribuições incidentes sobre o faturamento ou o lucro líquido, e também pela contribuição patronal e por destinações orçamentárias provenientes dos tributos sem destinação específica (Imposto de Renda, por exemplo), é financiada também pelos trabalhadores (além, não esqueçamos, de parte da receita auferida com os "concursos de prognósticos"). Outros fundos, porém, são mais claramente compostos por recursos dos próprios indivíduos para quem são destinados. É o caso do FGTS - Fundo de Garantia por Tempo de Serviço, cuja receita provém da própria remuneração do trabalhador. Se é verdade que é paga pelo empregador, por outro lado o valor do salário já é economicamente ajustado para que seja feito esse repasse, de forma que o fundo é alimentado pela massa salarial dos trabalhadores empregados formalmente. É um sistema de distribuição "horizontal", digamos assim, em que a tubulação destina recursos daqueles que estão empregados para, primordialmente, aqueles em situação de desemprego (momento da dispensa imotivada), entre outras hipóteses cabíveis. Nem sempre o que parece ser "redistribuição" o é na realidade: na verdade, é administração estatal de fundos financiados pelas contribuições dos próprios destinatários. ${ }^{83}$

\section{Diques e adutoras horizontais}

A redistribuição vertical é, como se vê, antes de tudo uma atividade estatal. O mecanismo é diverso a montante e a jusante. A montante, especialmente pela via tributária (mas não só, como vimos), o Estado retiraria riqueza das áreas de acumulação. A jusante, bom-

\footnotetext{
${ }^{83}$ Para uma crítica desse mecanismo nos modelos social-democratas europeus do Pós-Guerra (especialmente do alemão) e da ilusão redistributiva que gera sua instituição (e seus complexos mecanismos de financiamento), veja-se Roseli Martins Coelho, Social-democracia: formas e reformas (São Paulo: Hu-
} 
bearia a riqueza para áreas carentes, distribuindo-a ou redistribuindo-a conforme algum critério. O processo deveria conduzir a maior igualdade (novamente: conforme algum critério). ${ }^{84}$ Há, porém, outros mecanismos além da sucção de renda e sua recolocação em outra área. É possível imaginar que se imponham vedações à transferência da propriedade ou a seu uso, por exemplo. O Direito Urbanístico, as normas de proteção ambiental, os dispositivos constitucionais que impõem o aproveitamento econômico da propriedade, por exemplo, são exemplos no terreno do Direito Público. Com eles, impõem-se prestações positivas aos particulares e restrições à livre exploração da propriedade. De um lado, tais mecanismos, sem a intervenção estatal prévia (ela pode ocorrer posteriormente através da atividade administrativa ou judicial sancionatória), impõem um deslocamento de riqueza. Impõe-se a uma área urbana que permaneceria desocupada, aguardando uma valorização para sua venda, seu "aproveitamento econômico", na expressão legal. O resultado é que o proprietário será levado a edificá-la dentro dos limites das Leis de Zoneamento e do Plano Diretor. Isso lhe significará um custo, ou seja, perda de riqueza que, se poderá ser recuperada futuramente, no momento em que a edificação compulsória está sendo feita ainda não ocorreu.

De outro lado, limitações à propriedade, de toda espécie, bloqueiam seu livre aproveitamento econômico. Pensemos no exemplo clássico e típico de externalidade econômica negativa: a poluição. Sem normas que proíbam atividades lesivas ao meio ambiente, a empresa será conduzida a transferir o custo da emissão de agentes poluentes para terceiros, que o suportarão. Uma empresa poluidora acarreta danos à saúde da comunidade em que se insere, o que, pensando apenas do ponto de vista econômico, significa um custo para estes indivíduos e para o Estado. $\mathrm{O}$ valor das propriedades vizinhas à fábrica sofrerá com a desvalorização. A sujeira imporá um custo adicional para eles, que terão de arcar com a limpeza de suas propriedades e seu ambiente. E assim por diante. Regras que limitam o direito

manitas, 2001).

${ }^{84}$ A existência de um critério ideal, que decorreria de um modelo que parte de uma situação abstrata inicial (o estado inicial em que os indivíduos se cobrem com o "véu da ignorância"), é talvez um dos pontos mais controversos da teoria da justiça rawlsiana. Uma reformulação, que admite a crítica e, mais ainda, constata a possibilidade de haver vários critérios igualmente legítimos de distribuição, é a de Amartya Sen em $A$ ideia de justiça e a correspondente tentativa de solucionar a dificuldade a partir de uma teoria da escolha social (a democracia como exercício público da razão que conduz à escolha dos critérios). O que importa aqui, no entanto, não é a reconstrução do debate, mas antes o fato de que a filosofia do Direito Privado "distributivista" possui um ponto cego: conforme o critério a ser adotado - e Kronman escolhe Rawls - as normas a serem examinadas poderão ser ou não sustentáveis, conduzindo a análise a resultados opostos e incompatíveis. O que obviamente compromete o próprio projeto de entendê-las como expressão jurídica de uma teoria da justiça distributiva mais ampla. 
de propriedade, impondo ao poluidor que arque com o custo da poluição e não o transfira a terceiros (à sociedade) como que "bloqueiam" a concentração da riqueza. Ao impor ao poluidor o custo com a proteção ou mesmo vedar certas atividades econômicas, a legislação obsta a concentração ou impõe sua desconcentração sem a necessidade de mecanismos estatais de redistribuição. Tais normas, assim, têm como efeito obstruir um movimento natural, em outras condições, de concentração da riqueza. Poder-se-ia dizer então que construiriam diques horizontais que previniriam o adensamento da riqueza, ou ainda dispositivos de pressão para sua desconcentração horizontal.

As regras clássicas de limitação ao direito de propriedade, já previstas desde muito tempo (direito de vizinhança, por exemplo, ou direitos dos condôminos), são também um caso exemplar, mas agora no Direito Civil. O Direito do Trabalho está repleto desses exemplos e é o campo mais claro em que eles se exibem, como a imposição de limitação da jornada de trabalho, a imposição de pagamento de adicionais e outros encargos e assim por diante. Nesse "ramo" do direito a colocação de diques horizontais que restringem a concentração decorre da própria natureza cogente dessas normas (cogente, isto é, não dispositiva, pois não se admite outra opção para empregado ou empregador). A proteção do consumidor no momento da contratação e durante sua execução, no Código de Proteção e Defesa do Consumidor; a proteção a acionistas minoritários na Lei das Sociedades por Ações; a Lei de Locação, ao proteger o locador, também é um último, porém não derradeiro, exemplo de corpo legislativo de efeitos distributivistas.

Não é tão difícil ver tais efeitos em dispositivos legais ou na jurisprudência protetivos do que se costuma denominar de "partes vulneráveis". Registre-se, para fins de precisão, que a expressão "hipossuficientes", também freqüentemente utilizada no senso comum (não na dogmática consumerista, naturalmente), constitui um conceito técnico-jurídico bastante preciso, especialmente no Direito do Consumidor e indica a posição da parte no processo e especialmente na produção da prova. É por isso que o Código de Proteção e Defesa do Consumidor atribui ao consumidor "a facilitação da defesa de seus direitos, inclusive com a inversão do ônus da prova, a seu favor, no processo civil, quando, a critério do juiz, for verossímil a alegação ou quando for ele hipossuficiente, segundo as regras ordinárias de experiências" (art. 6. ${ }^{\circ}$, VIII do Código de Proteção e Defesa do Consumidor). Seja como for, nesses casos, um critério que identifica sua vulnerabilidade e a necessidade de sua “proteção" justifica o conteúdo da norma. O empregado, tomado individualmente, é vulnerável perante seu empregador. Seu poder de negociação é restrito, limitado, até mesmo i- 
nexistente. A proteção legal a seus interesses mais básicos, portanto, como a limitação da jornada de trabalho, estaria justificada, e argumentos semelhantes podemos construir para os demais exemplos que apresentamos acima. Nesses casos, novamente examinando o fenômeno de maneira agregada, observaremos a presença de "diques de contenção" do deslocamento de riqueza e renda, de um grupo ou classe social para outro. ${ }^{85} \mathrm{O}$ locador não pode se valer de sua posição de supremacia para impor ao locatário, por exemplo, que suporte o custo das despesas extraordinárias do condomínio (art. 22, inciso $\mathrm{X}$, da Lei $\mathrm{n}$. 8.245, de 18 de outubro de 1991). Agregadamente, uma barreira é erguida que impede a transferência de renda do grupo locatário, nesse caso específico, para o grupo locador. $\mathrm{O}$ grupo dos locadores-rentistas vê, assim, limitada legalmente sua capacidade de absorver a renda do grupo dos locatários. A transferência continua a existir, porém limitada, restrita pela presença da válvula que a atenua.

Se o fenômeno parece ser claro nesse tipo de norma, restaria saber se ele poderia ser estendido para a totalidade do Direito Privado, aplicando-se a partes que não parecem ser vulneráveis. A premissa metodológica exige que se possa submeter a esse teste as normas de Direito Privado, para, ao final, verificar-se se elas também podem revelar esse mesmo efeito distributivo. Afinal, parece um tanto surpreendente, à primeira vista ao menos, que uma norma que disciplina, para retornarmos a nosso exemplo, o vício redibitório, consistiria na verdade num artifício jurídico de uma teoria da justiça distributiva. Se a operação metodológica puder ser levada a bom termo, o Direito Privado (talvez "o" direito como um todo) poderia ser absorvido por uma teoria da justiça distributiva, de que ele seria a face jurídica "horizontal".

O instrumento que permitiria ver esse fenômeno, como vimos, é a agregação das operações de transferência de riqueza e seu confronto com a norma que a preside, em contraste com sua ausência. Dito de forma mais simples, trata-se de examinar os efeitos gerais da supressão da norma de Direito Privado a partir de seus resultados distributivos. Voltemos ao exemplo: tomemos a norma que impõe o dever de informar ao alienante do vício da coisa. Deixemos a operação econômica particular concreta de lado e agrupemos todos os negócios jurídicos em que ela possa ter incidido. Numa "experiência de pensamento" galilaica, suponhamos sua inexistência: no caso, que cabe ao adquirente acautelar-se e investi-

\footnotetext{
85 "Grupo" ou "classe" social, já que, por exemplo, locadores não correspondem a uma posição dentro das relações de produção.
} 
gar a qualidade da coisa que adquire ou assumir o risco. Nesse caso, o grupo dos adquirentes, se estivermos diante de uma situação (raríssima e artificial) de concorrência perfeita, poderá tentar barganhar o preço com o alienante, transferindo-lhe parte do custo pela averiguação da qualidade da coisa (custo de transação) ou do risco que lhe pode acarretar. Como tais condições são raras, a supressão hipotética da norma implicará na transferência de riqueza de um pólo mais forte ao outro.

Um segundo método para atingir a justiça distributiva envolve uma regulação mais direta dos termos com base nos quais se permite que os indivíduos transacionem entre si. Chamarei esse método de redistribuição de regulação contratual. Para ilustrá-lo, suponha mais uma vez que a todos é dada uma parcela equânime de recursos sociais. Desta vez, porém, em vez de deixar as pessoas livres para transacionarem como lhes aprouver e impor um tributo periódico sobre sua riqueza, uma tentativa é feita de preservar a equidade da distribuição original de recursos restringindo os termos com base nos quais é permitido aos indivíduos alterar suas posses através de trocas voluntárias - proibindo certas transações e, talvez, impondo outras. Leis de salário mínimo, por exemplo, impõem restrições dessa espécie. Tais leis tentam assegurar uma distribuição justa da riqueza entre trabalhadores e empregadores especificando, em parte, os termos com base nos quais podem contratar para vender seu trabalho. ${ }^{86}$

Noutras palavras, mesmo nessa norma, que aprendemos nos primeiros dias dos bancos escolares (quando somos iniciados à "comunidade jurídica interpretativa" de que faremos parte) ser destinada a disciplinar relações entre "partes iguais em equilíbrio" 87 (é para elas que o Código Civil é destinado; para as demais, chamemos talvez o Código de Proteção e Defesa do Consumidor ou a CLT) se revelaria um artifício para conter transferências de riqueza consideradas injustas por uma teoria da justiça distributiva.

Num quadro assim, a justiça comutativa, que presidiria as relações de Direito Privado para a "tradição aristotélica", passa a ser absorvida na teoria da justiça distributiva e ali

\footnotetext{
${ }^{86}$ Anthony Kronman, "Contract Law and Distributive Justice", op. cit., p. 499. Kronman prossegue debatendo com Rawls, para quem que tal método interferiria na liberdade individual. A natureza liberal dessa teoria, cujo objetivo é garantir a igualdade distributiva (nesse sentido) assegurada a liberdade individual, é evidente.

${ }^{87}$ O movimento de constitucionalização do Direito Privado (do Código Civil em primeiro lugar) insiste que deva ser interpretado pelo princípio constitucional da igualdade substancial. Quaisquer que sejam as críticas que se possa fazer a esse movimento - a Constituição é, ela própria, um texto a ser interpretado, de sorte que a interpretação "constitucional" do Código Civil redunda num círculo vicioso, projetando na Constituição aquilo que deseja que ela lance sobre ele -, o fato é que mesmo a igualdade substancial não afasta o princípio metodológico conforme o qual o Código Civil é uma norma que compõe uma narrativa cujos personagens são sempre indivíduos. Não assim, por exemplo, com o Código de Proteção e Defesa do Consumidor, onde a narrativa envolve fornecedores (leiam-se: empresas, ainda que não se exclua a pessoa natural) e consumidores (leiam-se: indivíduos, ainda que não sejam excluídas empresas). Para uma longa interpretação do Código Civil sempre a partir do princípio da igualdade substancial, veja-se Cristiano Chaves de Farias, e, Nelson Rosenvald, Curso de Direito Civil - Teoria Geral, op. cit.
} 
se perde. O princípio da força obrigatória dos contratos tem como contrapartida seu oposto: que os custos impostos a partes em posição de desequilíbrio real (não necessariamente vulneráveis, diga-se: podemos estar diante de grandes empresas) no caso concreto acarretariam distorções intoleráveis para uma teoria da justiça distributiva. Já, por outro lado, o princípio da relativização dos contratos, por outro lado, que flexibilizaria o princípio da força obrigatória, procuraria compensar o princípio anterior para afastar os efeitos concentracionistas de uma aplicação dura do pacta sunt servanda. Negar efetividade ao princípio que impõe a reparação do dano significaria, afora a violação do monopólio estatal da violência legítima e a autorização do exercício arbitrário das próprias razões, transferência relativa de riqueza ao grupo dos causadores do dano em comparação com o grupo das vítimas do ato ilícito. E assim por diante.

\section{Estática e dinâmica de uma hidráulica jurídica}

A idéia, portanto, é mais do que simplesmente sugerir que se podem encontrar mecanismos de distribuição ou impedimento de concentração de riqueza nas relações jurídicas assim chamadas de "horizontais" (indivíduo-indivíduo). O projeto é mais audacioso: é absorver o Direito Privado no campo da teoria da justiça distributiva. Se as análises econômicas do direito pretendiam invadi-lo e colonizá-lo, contaminando-o de microeconomia, a teoria distributivista pretende uma anexação do território. Naturalmente que, se ainda se podia falar em "autonomia" desse "ramo" do direito enquanto as forças de resistência neokantianas ou neoaristotélicas pretendiam defendê-lo - se o Direito Privado estabelece os limites das esferas de liberdade como autonomia, ou exprime uma virtude específica que é a justiça comutativa, então não pode ser reduzido a um território do "Direito Público" com esta última investida o Direito Privado perde definitivamente sua independência. Dentre os vários instrumentos jurídicos pelos quais uma sociedade restitui a justiça a um certo estado de coisas, o Direito Privado seria apenas mais um deles. Mas nesse caso, como o Direito Público também teria essa função — não mais a função liberal clássica de estabelecer limites ao poder do Estado, mas disciplinar a administração estatal dos recursos sociais —, a fronteira entre ambos se esvai. Se alguma diferença ainda persiste, é apenas quanto aos meios e procedimentos. E como cadeiras escolares que só existem independentes porque seus departamentos se situam em andares distintos do mesmo edifício administrativo.

É assim que o direito como um todo, como conjunto de normas formando um sistema, se revelaria ser a "face objetiva" — para falarmos novamente com Hegel — dessa teo- 
ria da justiça distributiva (para Kronman, rawlsiana). Diques de contenção de transferência de riqueza podem ser criados através de normas que prevejam nulidades ou imponham o dever de indenizar. A sistemática mais minuciosa que disciplina não só os princípios mais gerais dos contratos ou da responsabilidade civil, mas também de suas diversas espécies, das várias hipóteses de responsabilidade civil (incluindo a objetiva, aplicada a particulares ou ao Estado), ou mesmo os direitos sucessórios e os direitos patrimoniais da família (alimentos, por exemplo), corresponderiam a um sistema de contenção e canalização horizontal de riqueza, que, por um ângulo estático, não percorre o Estado, prescindindo de sua intervenção ativa para seu funcionamento. Já "verticalmente" acoplariam ao anterior um outro sistema, que o completaria e transporta riqueza de um grupo para outro, como que reequilibrando os reservatórios. ${ }^{88}$ Trata-se de um "sistema de bombeamento", em que o Estado lança mão sobre a riqueza de uns e a redistribui, diretamente (políticas diretas de distribuição de renda) ou indiretamente (serviços públicos ou mesmo, se assim entendermos, o braço complementar da intervenção na ordem econômica), ativamente.

A esse ângulo estático corresponderia, enfim, um ângulo dinâmico, essencialmente complementar ao primeiro sistema, sem o qual ele não ganharia efetividade. Uma teoria da justiça distributiva não ignoraria que a imposição de deveres que correspondem a artifícios para manter uma distribuição de riqueza exige o complemento de um sistema estatal que lhe dê efetividade. A ser assim, o direito praticado pelos tribunais é um direito redistributivista. Sua função última, ainda que não lhe apareça assim, é assegurar a efetividade de uma ordem jurídica que consiste num sistema de manutenção ou distribuição de riqueza social, seja pela via do Estado, seja pela via do Direito Privado. Não estamos referindo-nos ao "ativismo judicial" (embora a imposição coativa de políticas públicas ao Poder Executivo pelo Poder Judiciário pretenda ter esse efeito). Trata-se de simplesmente enxergar na decisão judicial mais banal, corriqueira e clássica, que condena, por exemplo, o causador do dano a indenizar a vítima, apenas como produto de um sistema institucional criado para conferir efetividade a normas que podem ser interpretadas a partir de uma teoria da justiça distributiva. Como normas sem sanção não possuem efetividade, ${ }^{89}$ sem sua imposição coativa $a$

\footnotetext{
${ }^{88}$ Esse conjunto de imagens, apesar de parecerem nascer no calor do período climático pelo qual passamos, encontra-se, na verdade, no texto de Kronman. Mera coincidência, notemos.

${ }^{89}$ A distinção entre eficácia e efetividade é complexa, pois diz respeito, em última análise, ao ponto de cruzamento mais alto entre o direito e o poder. Sabe-se que Kelsen pretendeu prescindir da segunda, exigindo do direito apenas um "mínimo de efetividade": afinal, sendo um conjunto escalonado de normas, o único conceito relevante para a identificação do direito seria a validade. Por outro lado, Carl S-
} 
posteriori (após sua violação) elas não atenderiam a sua função. Se estabeleceriam padrões de conduta, "razões suficientes" para aqueles dispostos a conduzir-se conforme elas, seriam inexistentes ou atém mesmo serviriam de ardil para aqueles que pretendessem descumpri-las. E, embora não se pleiteie (à diferença das análises econômicas do direito) que a interpretação jurisprudencial do direito se faça conscientemente a serviço dessa função - o Poder Judiciário não tem legitimidade para decidir o critério para identificar as diferenças relevantes entre os indivíduos e a necessidade de reequilibrá-los, ainda que ele não seja uma escolha arbitrária do legislador, mas nasça de uma teoria "racional" da justiça distributiva - , espera-se que ao menos a dogmática chame a atenção para ela.

O retrato que essa teoria nos apresenta, assim, é o de indivíduos em posições de desigualdade, estrutural ou situacional, reconhecidos pelo Direito Privado e tutelados por ele. "Estrutural", ou seja, como produto da dinâmica econômico-social e que deve ser retificada. Ou "situacional", pois, ainda que em pé de igualdade econômico-social — dois indivíduos que transacionam uma coisa que talvez esteja "eivada de vício" —, na situação concreta em que se encontram desponta uma desigualdade de poder. O retrato do indivíduo desigual a ser protegido pelo direito ancorado numa teoria da justiça distributiva, e pelo Direito Privado que agora não mais subsiste como independente em particular, é seguramente inusitado e pouco verossímil. Se a argumentação, internamente tomada, parece bastante razoável, contrasta com a visão tradicional do Direito Privado como conjunto de normas que disciplinam as "relações privadas" e nada deveriam a uma teoria da distribuição de bens sociais e recursos (direitos, riqueza, "faculdades", conforme a teoria da justiça distributiva que se escolha). Ainda que o Direito Privado sofra de uma "crise de identidade", com sua ascendente "publicização" e com o reconhecimento crescente da necessidade de proteger de iure relações de facto desiguais, a tendência doutrinária é a de fazer convi-

chmitt, em vários pontos seu antípoda, recusará a tentativa normativista de redução do direito, como sistema, ao conceito de validade. Direito é, antes de tudo, efetividade, para a "teoria do ordenamento jurídico concreto", já que expressa em última instância a soberania, ou seja, o poder em última instância. Para a distinção entre eficácia (produção de efeitos jurídicos), eficácia social e efetividade, indicando seus limites conceituais, veja-se Tércio Sampaio Ferraz Júnior, Introdução ao Estudo do Direito - Técnica, Decisão, Dominação (4 Ed. São Paulo: Atlas, 2002), p. 197-202. E especificamente para o debate acerca da natureza do direito entre Kelsen e Carl Schmitt, veja-se Ronaldo Porto Macedo Jr., Carl Sch- 
ver em setores separados normas destinadas a indivíduos "iguais" e "desiguais". A maioria das normas civilistas tradicionais não asseguraria reequilíbrio ou de proteção a um estado de equilíbrio (excetuadas as que reconhecem situações "materialmente" desiguais, como as normas clássicas que protegem o incapaz, por exemplo).

Essa crítica ainda deve conviver com outra crítica, clássica e nascida na tradição marxista, na qual adentraremos mais a fundo em breve. ${ }^{90}$ Para esta tradição, a função do Direito Privado é exatamente a oposta à presumida função redistributiva que nele encontra Kronman: é a manutenção de uma situação de desequilíbrio entre as partes, que passam a ser tomadas juridicamente como iguais quando não o são. É assim que o contrato de trabalho, na sua origem (estamos nos referindo aos séculos XVII e XVIII, ou seja, à manufatura e à indústria, antes das primeiras conquistas sociais do século XIX), foi traduzido nas categorias clássicas da "prestação de serviços", contrato já disciplinado pelo Direito Romano. A compra e venda da força de trabalho, por conseguinte, aparecia como troca de equivalentes e como uma relação entre iguais - dois indivíduos, atomizados, um dos quais a adquiria e o outro, a vendia - , modo de expressão da esfera da circulação. Ocorre que a esfera econômica da circulação seria a maneira como apareceria, no sentido hegeliano preciso de "aparecer", a esfera da produção, onde, agora sim, não haveria troca de equivalentes e as partes não estariam em posição de igualdade.

A ser assim, o Direito Privado não consistiria num repositório de instrumentos para assegurar a justiça distributiva. Muito pelo contrário, sua função seria precisamente a oposta. E uma teoria do Direito Privado que pretendesse afirmar que consiste num sistema de normas para assegurar a distribuição justa da riqueza se revelaria uma forma perversa de ideologia - como, cada uma a seu modo, as demais teorias examinadas nos capítulos anteriores:

A esfera da circulação ou da troca de mercadorias, em cujos limites se move a compra e a venda da força de trabalho, é, de fato, um verdadeiro Éden dos direitos inatos do homem. Ela é o reino exclusivo da liberdade, da igualdade, da propriedade e de Bentham.

mitt e a fundamentação do direito (2. ed. São Paulo: Saraiva, 2011), p. 93-108.

90 "Se, portanto, a forma econômica, a troca, põe a igualdade dos sujeitos em todos os sentidos, o conteúdo, a matéria, tanto individual como objetiva, que impele à troca, põe a liberdade. Igualdade e liberdade, por conseguinte, não apenas são respeitadas na troca baseada em valores de troca, mas a troca de valores de troca é a base produtiva, real, de toda igualdade e liberdade. Como idéias puras, são simples expressões idealizadas dessa base; quando desenvolvidas em relações jurídicas, políticas e sociais, são apenas essa base em uma outra potência." (Karl Marx, Grundrisse : manuscritos econômicos de 18571858: esboços da crítica da economia política. Trad. de Mario Duayer, Nélio Schneider. São Paulo: Boitempo; Rio de Janeiro: Ed. UFRJ, 2011), p. 297-298. 
Liberdade, pois os compradores e vendedores de uma mercadoria, por exemplo, da força de trabalho, são movidos apenas por seu livre-arbítrio. Eles contratam como pessoas livres, dotadas dos mesmos direitos. O contrato é o resultado, em que suas vontades recebem uma expressão legal comum a ambas as partes. Igualdade, pois eles se relacionam um com o outro apenas como possuidores de mercadorias e trocam equivalente por equivalente. Propriedade, pois cada um dispõe apenas do que é seu. Bentham, pois cada um olha somente para si mesmo. A única força que os une e os põe em relação mútua é a de sua utilidade própria, de sua vantagem pessoal, de seus interesses privados. E é justamente porque cada um se preocupa apenas consigo mesmo e nenhum se preocupa com o outro que todos, em conseqüência de uma harmonia preestabelecida das coisas ou sob os auspícios de uma providência todo-astuciosa, realizam em conjunto a obra de sua vantagem mútua, da utilidade comum, do interesse geral. Ao abandonarmos essa esfera da circulação simples ou da troca de mercadorias, de onde o livre-cambista vulgaris [vulgar] extrai noções, conceitos e parâmetros para julgar a sociedade do capital e do trabalho assalariado, já podemos perceber uma certa transformação, ao que parece, na fisiognomia de nossas dramatis personae [personagens teatrais]. $\mathrm{O}$ antigo possuidor de dinheiro se apresenta agora como capitalista, e o possuidor de força de trabalho, como seu trabalhador. O primeiro, com um ar de importância, confiante e ávido por negócios; o segundo, tímido e hesitante, como alguém que trouxe sua própria pele ao mercado e, agora, não tem mais nada a esperar além da... despela. ${ }^{91}$

A teoria distributivista do direito particulariza-se, assim, em contraste com as teorias tanto da autonomia da vontade quanto da justiça comutativa, por pretender apontar para algo oculto, fora do direito, de que ele seria a expressão aparente - justamente uma teoria da justiça distributiva. Nisso ela se aproxima, paradoxalmente, das análises econômicas do direito, que também pretendem fornecer um "verdadeiro sentido", exterior, para o direito - aquilo que o explicaria e definiria. As duas têm em comum o fato de sustentarem que o direito (privado, mas não só) apenas pode ser compreendido a partir de sua função, não de uma "racionalidade interna" ou uma "moralidade intrínseca", como querem as demais teorias. Há algo escondido que o preside e precisa ser revelado para quem lida com o direito, e esse algo é sua "função distributiva de riqueza ou de sua maximização". Funcionalizando o Direito Privado, explica-se a colonização pelo Direito Público, sua "publicização" e a crise mesmo dessas categorias - "Direito Privado" e "Direito Público", conceitos que, de resto, mesmo quando tentaram ser refinados (no século XIX, e não no Período Pós-Clássico do Direito Romano, como sempre querem alguns), permaneceram instáveis —, e especialmente a partir da eclosão do "Direito Social", nem público, nem privado, nem estatal, nem particular. A explicação, para o jusdistributivista, seria singela: as categorias só fazem sentido se pretenderem descrever características do conteúdo das normas (atuação estatal dire-

${ }^{91}$ Karl Marx, O Capital - Crítica da economia política (Livro I: O processo de produção do capital. Trad. Rubens Enderle. São Paulo: 2013), p. 322-323. 
ta ou mecanismos de controle da transferência de riqueza: "verticalidade" ou "horizontalidade"). Mas não teria razão de ser se pretendesse descrever uma fronteira entre os reinos rivais, já que todas estariam, ou deveriam estar, a serviço de um sistema de proteção e promoção da justiça "no sentido distributivo". Haveria ainda utilidade em utilizar tais distinções, pois patos e cisnes são animais distintos - ainda que, observando-os bem, não passem de anatídeos.

Sabemos que Paschukanis afirmará que o núcleo organizador do Direito Privado não é a responsabilidade, mas, naturalmente, o contrato, forma jurídica que reflete, no direito, a forma-mercadoria e a troca de equivalentes. A conseqüência, de uma radicalidade encantadora, não é que o Direito Privado é uma categoria inútil em razão de sua absorção pelo Direito Público. Precisamente o contrário: contrapondo-se a Léon Duguit, Paschukanis sustentará que o Direito Público é a expressão ideológica do Direito Privado, pois reflete a contradição ideológica das sociedades em que prevalece o modo de produção capitalista entre o interesse individual e social:

É muito claro que a lógica dos conceitos jurídicos corresponde à lógica das relações sociais de uma sociedade de produção mercantil. Precisamente nessas relações, e não no consentimento da autoridade pública, é onde há que se buscar a raiz do sistema do direito privado. Ao contrário, a lógica das relações de dominação e servidão entra somente em parte do sistema dos conceitos jurídicos. Por isso, a concepção jurídica do Estado nunca pode converter-se numa teoria e permanece sempre como uma deformação ideológica dos fatos.

Por conseguinte, prossegue ele:

A teoria jurídica não pode identificar os direitos do Legislativo, os direitos do Executivo, etc., por exemplo, com o direito do credor à restituição da quantia mutuada, pois isso significaria substituir a dominação do interesse estatal geral e impessoal, presumido pela ideologia burguesa, pelo interesse privado isolado. Mas ao mesmo tempo cada jurista está consciente do fato de que não pode dar a esses direitos nenhum outro conteúdo fundamental sem que, com isso, a forma jurídica lhe escape das mãos. O Direito Público só pode existir enquanto reflexo da forma jurídica privada na esfera da organização política, ou então de maneira geral deixa de ser um direito. Toda tentativa dirigida a apresentar a função social pelo que é, ou seja, simplesmente como função social, e a apresentar a norma simplesmente como regra organizadora, significa a morte da forma jurídica. A condição real dessa supressão da forma jurídica e da ideologia jurídica é um Estado social no qual é superada a contradição entre o interesse individual e o interesse social. ${ }^{92}$

Paschukanis, porém, não foi capaz de escapar da ilusão da norma como elemento fundamental do direito. Para ele, o Direito Público existe como "reflexo da forma jurídica privada na esfera da organização política”. Mas tanto o Direito Público quanto o Privado, todos,

\footnotetext{
92 Jewgeni Paschukanis, La Teoría General del Derecho y el Marxismo. (Trad. de Carlos Castro. Ciudad
} 
têm em comum o fato de constituírem-se num sistema de regras que é alinhavado pela "forma jurídica", reflexo da forma-mercadoria. Mesmo esse grande autor, que debateu com Kelsen e Weber, em sua época, em pé de igualdade e hoje em dia tão pouco freqüentado (com poucas exceções no Brasil e um pouco mais no exterior), não conseguiu afastar-se da força alucinatória do direito como sistema de normas, ou, como chamaremos a seguir, do "nomocentrismo".

Os quatro retratos acima levam ao limite imagens que guiam tacitamente, sorrateiramente, a produção do Direito Privado. As teorias que os constroem podem agora começar a revelar-se construções ideológicas de sua legitimação. Guardemos a categoria, porém "Direito Privado" - agora com todas as cautelas, empregando as devidas luvas e, quem sabe, nano-pinças para manipular esse nano-objeto facilmente perecível. Ela tem de permanecer viva por mais alguns instantes para que seu duplo caráter ideológico possa ser exposto: como sobreposição de imagens-narrativas e como fetiche normativista. Pois diante de tudo isto, resta-nos finalmente buscar uma resposta à pergunta inicial: como o Direito Privado, como atividade prática, é possível a partir dessas imagens-narrativas que as "filosofias do Direito Privado" escolheram como pedra fundamental de seus edifícios?

Resta-nos passar da arqueologia dos retratos do indivíduo jusprivatístico a sua crítica. 


\section{Conclusão:}

\section{RETRATOS:}

\section{Para a Crítica das Filosofias do Direito Privado}

\section{Questão de método: a lavra e o mineral}

As teorias expostas nos capítulos anteriores foram-nos úteis pelo que fazem exibir do Direito Privado. Tomemo-las pelo seu valor de mercado, não pelo que efetivamente pretendem valer. Sua diafonia permite que prescindamos daquela que é sua pretensão essencial: encontrar a fundamentação do Direito Privado. Não precisamos comprometer-nos com tais pretensões. Basta-nos algo mais modesto e de longe nem um pouco irrelevante: o que descobriram com seu projeto. Porque ao procurarem um fundamento, magnetizaram a representação subjacente ao Direito Privado de tal maneira que, artificialmente purificada ao mesmo tempo em que contagiada por teorias filosóficas, realçaram, polarizando-as, as imagens-guia que lhe eram subjacentes. Devemos, agora, abandoná-las e recolher o produto dessa prospecção. Mais uma vez: a dissonância pode conduzir-nos à desconfiança. Consistentes com as respectivas efígies a que escolheram dar relevo e com os respectivos corolários jurídicos delas pendentes, colidem com as pretensões das teorias rivais e disparam um "debate" que não deve dispersar nossa atenção. Antes, deve ser a marca de seu caráter de ideologia.

Portanto, a exposição das teorias acima não tinha como finalidade reconstruir a controvérsia entre elas, nem tampouco sua estrutura interna ou as insuficiências argumentativas de que possam padecer. Menos ainda apresentar a defesa de alguma dentre elas, supostamente superior às demais. Servindo-nos de instrumento, confundamos o resultado com o 
método. Se o primeiro é impossível sem o segundo, e este o determina, também é certo que aquele não se reduz a este. Um é impossível sem o outro e, por certo ângulo, um já é o outro, mas também não o é. Assim, a partir de agora, recolhamos o produto e deixemos os pressupostos das teorias. Interessa-nos as imagens que distinguiram na representação social produtora do Direito Privado como prática social.

Agora, porém, não se trata mais de examinarmos as imagens que elas nos apresentam, mas de retornarmos à elas como presentes no próprio direito. Elas, como vimos, para realçar tais imagens são obrigadas a empregar reagentes químicos tomados nas teorias filosóficas que escolhem para servir-lhes de fundamentos (Kant, Aristóteles, talvez Bentham ou Rawls). O grau de pureza alcançado não corresponde àquele que encontramos na prática jurídica do Direito Privado. Mesmo na dogmática civilista mais requintada conceitos como "autonomia da vontade" ou "comutatividade", ou a constatação de que a igualdade deve ser "substantiva", não avançam em requintes filosóficos. Nem poderiam, nem deveriam: permanecem num nível de vagueza e generalidade que aparam as arestas das efígies em alto-relevo, que, do contrário, se mostrariam incompatíveis e irreconciliáveis. É o que permite encontrarmos na jurisprudência a combinação, numa mesma decisão, de todas elas ao mesmo tempo (nem sempre sequer em parágrafos distintos!), sem que quem a redige sinta o mínimo incômodo ou embaraço. "Ser conseqüente é a máxima obrigação do filósofo; entretanto, é a que menos se observa", dizia Kant na Crítica da Razão Prática. Aqui, há que perdoá-la: não se está diante de filósofos.

Esse fenômeno - o desembaraço no emprego de imagens-guia da decisão e da organização do Direito Privado que, se acuradas, levariam à indefinição ou a uma escolha flagrantemente arbitrária, levando ao colapso a própria função dessa representação-guia deve deter nossa atenção agora. Examinemos sua síntese. 


\section{II. “Les Diableries” vistas pelo estereoscópio ${ }^{93}$}

a) Autonomia da vontade

Resgatemos a primeira imagem. Ela se apresenta no princípio da autonomia da vontade e descreve o retrato de um homem que quis praticar o ato jurídico cujos efeitos deverá suportar. No direito contratual, ele se apresenta como o indivíduo cuja manifestação (no rigor terminológico: declaração) exprime uma vontade livre - autônoma - que encontra a vontade, igualmente livre, de outro indivíduo e daí faz nascer um negócio jurídico. A imagem, assim, é a de dois indivíduos iguais, autônomos, que se comunicam e concluem um negócio jurídico declarando o que querem reciprocamente. O "encontro das vontades", 94 imagem freqüente na dogmática, origina uma relação jurídica que ganhará vida própria e obrigará ambas as partes com aquilo que se comprometeram. A autonomia da vontade, conceito operacional que alinhava o Direito Privado, traz consigo a imagem do indivíduo livre, igual, independente e racional, que empenha a palavra e a cumpre, respeitando a confiança recíproca que se espera.

Essa mesma autonomia está presente, como vimos, porém não de maneira expressa, na obrigação nascida da responsabilidade por dano causado pelo ato ilícito. Seja no dolo, que implica autonomia da vontade para causar o dano, seja na culpa, em que a lei impõe a

${ }^{93}$ Les Diableries - "As diabruras" - consistem numa série de fotografias estereoscópicas publicadas em Paris na década de 1860 e que descreviam a vida sob Napoleão III através de uma série de cenas satíricas do Inferno. Sua reprodução encontra-se no belo livro de Jac Remise, Diableries: La Vie Quotidienne Chez Satan a la Fin du 19e Siècle (Paris: Balland, 1978). Já o estereoscópio é um instrumento óptico simples, ainda encontrado em antiquários, consistente numa espécie de binóculo no qual são colocadas duas fotografias de um mesmo objeto tiradas a partir de perspectivas diferentes. Com isso obtém-se uma visão em três dimensões da cena, resultante da ilusão produzida no cérebro pela presença em cada olho de imagens diversas.

94 "Quanto à apontada predileção pelo instituto dos negócios jurídicos, preferindo-se a espécie ao gênero, fatos jurídicos, cabe notar que no negócio jurídico o que sobreleva não é o aspecto da 'declaração de vontades' - como sustentam alguns juristas - mas sim 'o encontro das vontades' para dar nascimento a um conjunto de direitos e obrigações. A bem ver, essa questão transcende os limites do Direito Civil para elevar-se à problematicidade das fontes do Direito. Como saliento em meu livro Fontes e Modelos do Direito, Hans Kelsen, se, por um lado, exagerou seu formalismo normativo, por outro lado genialmente alargou os horizontes da normatividade, acrescentando às três fontes tradicionais do Direito (fonte legal, fonte jurisdicional e fonte costumeira) uma terceira, a fonte negocial que emerge da própria sociedade civil através da autonomia de vontades concordantes, vontades essas que se conjugam para dar origem a direitos e deveres recíprocos, sobretudo através de avenças ou contratos. trata-se, em suma, como afirmo na citada obra, do poder negocial que instaura relações jurídicas válidas, desde que não conflitantes com expressas determinações de ordem legislativa." (Miguel Reale, "Um artigo-chave do Código Civil”, In: O Estado de S. Paulo 21/06/03, p. 3). 
responsabilidade ainda que não haja nexo causal propriamente dito (a culpa é sempre um descumprimento de um dever, logo, um não-agir), a vontade individual se faz pressuposta. É porque o indivíduo quis causar prejuízo, ou não se importou se ele ocorreria, ou ainda quis agir de maneira afoita (negligência) ou com excesso de autoconfiança (imperícia, imprudência), que o dano ocorreu. O querer individual está sempre pressuposto, bem como o dever correspondente de não prejudicar a outrem (alterum non laedere), aqui descumprido. Se a autonomia da vontade é um conceito que faz sua aparição mais freqüente no domínio do direito contratual, nem por isso deixa de permanecer no palco, ainda que num segundo plano. Afinal, se o indivíduo não tivesse querido agir como agiu, o dano não teria acontecido. E só não será responsabilizado se ficar provado que não queria, mas ainda assim o dano era inevitável (causas excludentes, como visto no Capítulo 1).

Esse indivíduo autônomo, abstrato como se depreende, portanto, é construído por uma narrativa pressuposta. Narrativa porque, como relato sob-reptício, pressupõe um desenrolar-se no tempo. Cuida-se de um indivíduo honesto e honrado, a quem nada impelia a agir exceto sua própria vontade livre. É um indivíduo que costuma se refrear perante os desejos, capaz de controlá-los e impor-se a eles. Homem sério, severo e austero, costuma acautelar-se ao agir e não é seu costume impor-se obrigações que não crê ser capaz de cumprir. Sobretudo é alguém a quem, negativamente, nada lhe foi imposto. Não foi coagido a contratar, não foi coagido a causar dano. Percebamos os verbos no passado na construção de um conjunto de narrativas. É uma estrutura essencial para a conformação das diversas imagens e reaparecerá organizando cada uma delas.

O baixo-relevo dessa efígie nos mostra assim a fábula do homem livre cuja responsabilidade, portanto, é absoluta. Liberdade e responsabilidade, portanto, interligam-se como dois personagens inseparáveis dessa primeira imagem. Como a liberdade, nesse quadro, só existe se as partes estiverem em posição de paridade de poder (do contrário, uma impor-se-á à vontade da outra, que deixa de ser livre), estará pressuposta a igualdade entre elas. Igualdade, liberdade e responsabilidade são os três atributos fundamentais da narrativa que compara a conduta da qual decorre um dano (contratual ou extracontratual) e aquela, seu avesso, na qual o contrato teria sido inteiramente cumprido, ou o dano nunca teria acontecido. Vistos como iguais, livres porque iguais e, portanto, daí responsáveis, os indivíduos sujeitam-se aos efeitos jurídicos das condutas autonomamente escolhidas, por eles desejadas. 
b) "Eticidade"

A imagem do homem autônomo conduz-nos a outra figura na qual ela se transmuta. O homem autônomo, livre porque igual aos demais e, em razão disso, sempre responsável, associa-se à narrativa do homem de caráter. O Código Civil de 2002 foi elaborado, segundo o próprio coordenador da comissão que redigiu seu anteprojeto, submetendo-se ao princípio "da eticidade". ${ }^{95}$ Esse princípio, freqüentemente surgindo em contextos lingüísticos que o tornam dificilmente distinguível do "princípio da boa-fé objetiva” (segundo a dogmática, na verdade, este seria espécie do primeiro e seu uso, mais restrito à disciplina dos contratos ${ }^{96}$ ), descreveria um sistema de relações "éticas" que presidiriam as "relações privadas". Passamos aparentemente de modo imperceptível da narrativa do homem autônomo àquela de um homem que é honesto, qualidade que caracteriza agora seu caráter e se manifesta nos seus atos.

É assim que o Código Civil de 2002 emprega o termo "boa-fé" cinqüenta e cinco vezes (o de 1916 o empregava trinta e cinco). Os dispositivos que a mencionam se referem à maneira como devem ser interpretados os negócios jurídicos (art. 113: “conforme a boafé") e protegem os direitos de terceiros "de boa-fé" em face do vício da simulação (reparese: nulidade absoluta no Código Civil de 2002; art. 167, parágrafo 2. ${ }^{\circ}$ ). Estende o conceito de ato ilícito para aqueles exercidos excedendo "os limites impostos [...] pela boa-fé" (art. 187). Impõe - eis um dos pontos culminantes, perceba-se - que os contratantes guardem tanto na conclusão do contrato quanto na sua execução "os princípios de probidade e boafé" (o célebre art. 422 do Código Civil). Quanto ao contrato de seguro, num artigo que exemplifica com precisão os anteriores, este deve ser concluído e executado entre as partes guardando "a mais estrita boa-fé e veracidade, tanto a respeito do objeto como das circunstâncias e declarações a ele concernentes" (art. 1.765). E finalmente, mas haveria ainda muitos outros, o tutor deve cumprir seus deveres "com zelo e boa-fé", não podendo ser tu-

\footnotetext{
${ }^{95}$ Miguel Reale, O Projeto do Novo Código Civil. $2^{\mathrm{a}}$ ed. São Paulo: Saraiva, 1999, p. 7-12. O termo "eticidade" parece ter surgido posteriormente ao Anteprojeto encaminhado pela Comissão do Código Civil de 2002. Ela não aparece na Exposição de Motivos do Anteprojeto (diversamente dos princípios da "concreção", que irá desaparecer, e da "socialidade", que continuará nos textos posteriores de Miguel Reale).

${ }^{96}$ Mas não só. Historicamente, sabemos que uma vez publicado o Código Civil, o princípio da "boa-fé objetiva" transbordou para praticamente todos os ramos do direito. É assim que se passou a falar em "boa-fé objetiva da Administração", ou no princípio da "boa-fé objetiva das partes no processo" e até mesmo na "boa-fé objetiva no devido processo legislativo" (!).
} 
tores "as pessoas de mau procedimento, ou falhas em probidade, e as culpadas de abuso em tutorias anteriores" (art. 1.735, inciso V).

A leitura do Código Civil, examinando todas suas ocorrências, permite constatar a presença de dois usos da expressão "boa-fé". A primeira, uma inovação do Código Civil de 2002, consiste num dever imposto aos contratantes ou ao homem em geral de não causar dano agindo desonestamente. É o sentido previsto nos arts. 187 e 422 do Código Civil. Neles, espera-se um comportamento honesto de todos, especialmente dos contratantes. Nos demais artigos, em que a expressão, via de regra, aparece conectada à preposição "de” (“de boa-fé"), é a honestidade de terceiros que é premiada, protegida. Esse é o sentido que aparecia no Código Civil de 1916 e cujo núcleo é a "posse de boa-fé": “É de boa fé a posse, se o possuidor ignora o vício, ou o obstáculo que lhe impede da aquisição da coisa, ou do direito possuído" e "a posse de boa fé só perde este caráter no caso e desde o momento em que as circunstâncias façam presumir que o possuidor não ignora que possui indevidamente" (arts. 490 e 491 do Código Civil de 1916). Note-se que a ignorância do vício revela, ou antes protege, uma presunção de "bom caráter" do possuidor. Desde a Ética a Nicômaco, o padrão argumentativo é o mesmo. Do contrário, agindo como homem honesto, será protegido contra o trapaceiro ou, pelo menos, não será prejudicado por não ter agido inescrupulosamente. Esses artigos são repetidos nos arts. 1.201 e 1.202 do Código Civil de $2002 .{ }^{97}$

A exigência de "honestidade" reaparece também em outros textos legais. Na Lei das Sociedades por Ações, que já tivemos a ocasião de indicar várias vezes, não emprega nem "boa-fé", nem "honestidade". No entanto, a expressão utilizada, mais longa e muito mais expressiva da justiça como comutatividade, é "o cuidado e a diligência que todo homem ativo e probo costuma empregar na administração de seus próprios bens" ou ainda "dos seus próprios negócios" (arts. 68, parágrafo 1. ${ }^{\circ}$, alínea "a": deveres dos agentes fiduciários e art. 153, deveres dos administradores, todos da Lei n. 6.404, de 15 de dezembro de 1976). A lei ainda menciona "lealdade" (o acionista controlador "deve usar o poder com o fim de fazer a companhia realizar o seu objeto e cumprir sua função social, e tem deveres e responsabilidades para com os demais acionistas da empresa, os que nela trabalham e para com a comunidade em que atua, cujos direitos e interesses deve lealmente respeitar e atender”, art. 116, parágrafo único; “O administrador deve servir com lealdade à companhia e

\footnotetext{
${ }^{97}$ O rigor acadêmico exige o registro: o art. 1.765 do atual Código Civil já existia no antigo Código Civil de 1916, correspondendo ao art. 1.443, e o art. 1.735, inciso V, se apresentava no art. 413, inciso V.
} 
manter reserva sobre os seus negócios”, art. 155) como traço de conduta do controlador ou do administrador. Poderíamos acrescentar outros, como a boa-fé que o consumidor, e, naturalmente, o fornecedor, devem manter nas suas relações recíprocas (art. 4, inciso III e art. 51, inciso VI, todos do Código de Proteção e Defesa do Consumidor), ou que o dever do locatário de tratar o imóvel "com o mesmo cuidado como se fosse seu" (art. 23, inciso III, da Lei n. 8.245, de 18 de outubro de 1991), ou o vaguíssimo "ato de improbidade" que constitui justa causa para rescisão do contrato de trabalho pelo empregador (art. 482, alínea “a” da Consolidação das Leis do Trabalho).

Veja-se que em todos esses casos deixamos os efeitos de uma vinculação decorrente da autonomia da vontade de um homem livre e igual aos demais, para adentrarmos calmamente (mas também nebulosamente) num terreno em que o indivíduo, agora, deve agir "honestamente", "probamente", "lealmente" ou "de boa-fé". As referências a que conduza os negócios de que é responsável como faria com os seus parecem ecoar o imperativo categórico, mas as expressões seguintes comprovam que se espera a revelação de um caráter honesto. Mais ainda, essa honestidade é medida pelo padrão negativo: o honeste vivere equivale agora a dar a cada um o que lhe é devido (suum quique tribuere) e não causar dano a ninguém. O retrato, assim, é o do homem livre, igual, responsável, mas também cauteloso, ativo, probo e leal, que cumpre com o contratado por ser honesto e não prejudica ninguém, pelo zelo com que trata as coisas alheias como se fossem suas. Sobrepõe-se, assim, à imagem anterior uma nova imagem, que se ajusta a ela com evidente dificuldade filosófica (uma ética do dever é francamente incompatível com uma ética da virtude, como deixa claro a Segunda Crítica), mas ao mesmo tempo com surpreendente placidez que parece beirar a ingenuidade dos simples.

\section{c) "Função social" como "Fim econômico"}

Não fosse isso suficiente, aos dois clichês anteriores sobrepõe-se ainda um terceiro: o dos efeitos "econômicos" das relações jurídicas, que devem ser levados em consideração em sua análise. Novamente, o art. 187 do Código Civil, como vimos, estende a noção de ato ilícito, impondo, por outra via, também um padrão interpretativo: "Também comete ato ilícito o titular de um direito que, ao exercê-lo, excede manifestamente os limites impostos pelo seu fim econômico ou social, pela boa-fé ou pelos bons costumes". Descobrimos então que os direitos têm um "fím econômico". O direito de propriedade, obviamente, "deve ser exercido em consonância com as suas finalidades econômicas e sociais” (art. 1.228, pará- 
grafo $\left.1 .^{\circ}\right)$. O mesmo artigo, em seu parágrafo $4 .^{\circ}$, chega até a introduzir no usucapião coletivo o elemento econômico: "se o imóvel reivindicado consistir em extensa área, na posse ininterrupta e de boa-fé, por mais de cinco anos, de considerável número de pessoas, e estas nela houverem realizado, em conjunto ou separadamente, obras e serviços considerados pelo juiz de interesse social e econômico relevante".

Claro que essas expressões são ambíguas. Elas aparecem, como se vê, por duas vezes ao lado do fim ou finalidade social do direito. O que signifique precisamente "social", termo de uma vagueza apavorante no direito, é algo que tem rendido muito trabalho para a dogmática. ${ }^{98}$ A célebre "função social do contrato" (art. 421 do Código Civil), que estipula a "finalidade" e os "limites" da liberdade de contratar ("a liberdade de contratar será exercida em razão e nos limites da função social do contrato") poderia ser identificada com sua "finalidade econômica", como as análises econômicas do direito tanto desejam. A verdade é que a palavra "social" no Código Civil é de tal forma ambígua que aparece nos mais variados contextos (um contrastante: o art. 1337, em seu parágrafo único, refere ao "reiterado comportamento anti-social" do condômino, em mais um exemplo do padrão do homem honesto e virtuoso, que dificilmente seria assimilável à função econômica da propriedade, nesse sentido preciso).

A Lei das Sociedades por Ações avança mencionando a "função social da empresa" no momento culminante em que deseja disciplinar a relação de poder mais forte dentro da sociedade anônima: $:{ }^{99}$ seja porque o controlador "deve usar o poder com o fim de fazer a

\footnotetext{
${ }^{98}$ Num texto — não se negue, rico conceitualmente — em que reflete doutrinariamente sobre a função social do contrato, uma de nossas melhores doutrinadoras, Judith Martins Costa, conclui: "Aliás, no campo da atividade negocial (seja o campo dos contratos, seja o da empresa), correta está a doutrina que indica a 'funcionalidade exógena' do princípio da função social, em contrapartida à 'normatividade endógena' dos princípios da boa-fé e da autonomia privada. Essa normatividade encontra fundamento em uma tradição muito antiga: a idéia de justiça legal, de Tomás de Aquino que, na Summa Teológica, assentou: à justiça legal pertence ordenar ao bem comum as coisas que são das pessoas particulares (Suma Teológica, II-II, 61, a.2). Aqui está o verdadeiro salto qualitativo que encontro no art. 421: o entender que a liberdade de cada um se exerce de forma ordenada ao bem comum, expresso na função social do contrato, pressupondo internamente conformado o direito de liberdade (de contratar) em campos de especial relevância ao bem comum. Na reconfiguração do direito subjetivo de contratar a capacidade adaptativa do Direito Civil - direito da vida, da experiência concreta - testada há dois mil anos, é chamada novamente a atuar." O leitor que avança no texto - de novo: doutrinariamente rico em distinções e conceitos úteis para a construção jurídica - termina por se perguntar, afinal, o que significaria, "na experiência concreta", o tão mencionado "bem comum". ("Reflexões sobre o Princípio da Função Social dos Contratos". Revista Direito GV, n. 1 (2005), p. 41-66).

${ }^{99}$ A descrição é de Fábio Konder Comparato em seu clássico $O$ Poder de controle na sociedade anôni$m a$ (Rio de Janeiro: Editora Forense, 2008), uma densa obra doutrinária que também pode ser lida como um romance econômico.
} 
companhia realizar o seu objeto e cumprir sua função social", seja porque os administradores devem também "exercer as atribuições que a lei e o estatuto lhe conferem para lograr os fins e no interesse da companhia, satisfeitas as exigências do bem público e da função social da empresa”. Como a Constituição Federal, em seu art. 170, inciso III, repete a expressão "função social", é freqüente verificarmos a oscilação doutrinária entre uma concepção vagamente distributivista do significado de "social" e sua identificação com a idéia de que ela deve servir para a promoção do crescimento econômico (daí, maximização da riqueza).

Se a propriedade deve atender a sua função social, e também os contratos, a posse, a empresa e tudo mais, como a expressão não possui um significado preciso, é freqüente sua assimilação à exploração econômica, satisfeitas as limitações legais. Assim, a propriedade imobiliária satisfaz sua função social se o terreno não permanece não-edificado, se o proprietário obedece à disciplina prevista no Plano Diretor para sua destinação na área em que está construído, se as normas ambientais são satisfeitas e assim por diante. Mas sua função social, aqui, não parece distinguir-se de seu aproveitamento econômico, num vago juízo negativo à manutenção do imóvel inexplorado num contexto de especulação, ou num também vago juízo positivo de que sua exploração econômica ocorre "em benefício da coletividade". Daí a sedução doutrinária pelas análises econômicas do direito, mas também pela concepção do indivíduo racional que maximiza a satisfação de seus interesses. E daí também a teoria do direito subjetivo que o concebe como um "interesse juridicamente protegido". A definição de Silvio Rodrigues, recorrendo a Luis Eulálio de Bueno Vidigal, não poderia ser mais reveladora dessa imagem do homem utilitarista que já não é nova: ${ }^{100}$

Meu eminente colega Luiz Eulálio de Bueno Vidigal (Da execução das obrigações de prestar declaração de vontade, São Paulo, 1940, n. 17) define com muita sabedoria o direito subjetivo. Depois de conceituar a idéia de interesse como a disposição do homem para obter bens a fim de satisfazer suas necessidades, mostra como o direito, através da relação jurídica, procura regular os conflitos de interesses que nascem entre os indivíduos. A prerrogativa do indivíduo de invocar a lei na defesa de seu interesse é o direito subjetivo. Ou, na frase lapidar do consagrado professor: "Direito subjetivo é o poder atribuído à vontade de alguém para fazer valer o seu interesse, em conflito com o interesse de outro. Direito privado é o que regula as relações entre os homens, tendo em vista o interesse particular dos indivíduos, ou a ordem privada. Ele disciplina as relações humanas que surgem no âmbito familiar; as obrigações que se estabelecem de indivíduo para indivíduo, quer oriundas do contrato, quer derivadas do delito, quer provenientes da lei; os direitos reais sobre coisas próprias, ou seja, o domínio, e os direitos reais sobre coisas alheias, tais como a enfiteuse, o usufruto, as servidões etc.; e ainda as questões que se ligam à transmissão da propriedade causa mortis. Esse é o direito privado. Aliás, poder-

${ }^{100}$ Silvio Rodrigues, Direito Civil-Parte Geral. Vol. I, op. cit., p. 8-10. 
se-ia dizer, de maneira mais ampla, que esse é o Direito Civil, pois em certos momentos as expressões se equivaleram". ${ }^{101}$

"Fazer valer o seu interesse, em conflito com o interesse de outro", "regula as relações entre os homens, tendo em vista o interesse particular dos indivíduos, ou a ordem privada" e, finalmente, "interesse como a disposição do homem para obter bens a fim de satisfazer suas necessidades": reconheçamos o indivíduo utilitarista clássico, com desejos,

${ }^{101}$ Parece-me valer a pena relembrar a classificação e a análise mais detalhada de Washington de Barros Monteiro, um de nossos maiores civilistas clássicos, ao expor as "teorias do direito subjetivo":

"Variam, no entanto, profundamente, as opiniões quanto ao modo de encarar os direitos subjetivos. Em posições diametralmente opostas situaram-se as doutrinas afirmativas e as doutrinas negativistas. Partem as primeiras do mesmo pressuposto, a existência dos direitos subjetivos, desdobrando-se, porém, depois, em aspectos diferentes, salientados pela teoria da vontade, teoria do interesse e teoria mista. Para a primeira, o direito subjetivo constitui um poder ou uma senhoria da vontade. Quem tem um determinado direito, em virtude do ordenamento jurídico, pode agir consoante a norma, de que aquele direito deriva. Mas, se o elemento volitivo realmente representa um dos dados do problema, não esgota, contudo, o conceito do direito. Não se pode situar a vontade na base do direito subjetivo, porquanto, freqüentemente, compete este a seres destituídos de vontade, como os loucos de todo o gênero e os ausentes. Além disso, a subsistência do direito independe, muitas vezes, de qualquer manifestação de vontade de seu titular. Assim, quem penetre numa propriedade alheia viola o direito do respectivo proprietário, embora não exista proibição emanada deste. A teoria do interesse não identifica o direito subjetivo pelo princípio da vontade. Esta não é o fim, nem a força motriz dos direitos. A utilidade é que representa a substância destes. O direito subjetivo caracteriza-se, portanto, pelo interesse, definindo-se como o interesse juridicamente protegido, ou como o interesse humano garantido pela ordem jurídica. Tal concepção, igualmente unilateral, sofreu críticas muito fortes. Direitos existem que dificilmente se ligarão a um interesse, assim como também interesses há que não logram obter tutela e proteção do direito. A teoria mista propõe-se a definir o direito subjetivo, conjugando o elemento vontade com o elemento interesse. Assim, para Jellinek direito subjetivo é o interesse protegido, que a vontade tem o poder de realizar. É expressão da vontade individual, como o direito objetivo é a expressão da vontade geral. Em contraposição às citadas teorias afirmativas, mencionem-se as teorias negativistas, entre as quais se destacam a de Duguit e a de Kelsen. [...] Insurgindo-se assim contra o direito subjetivo, que considera entidade metafísica, a ser banida da moderna linguagem jurídica, termina Duguit por afirmar que esse direito não existe. [...] Também Kelsen opõe ao direito subjetivo negação terminante. Seu livro intitulado Teoria Pura do Direito contém um capítulo sob esta rubrica: redução do direito subjetivo ao direito objetivo. Efetivamente, para Kelsen, a obrigação jurídica não é senão a própria norma jurídica, considerada do ponto de vista do comportamento que ela impõe a um indivíduo determinado. Assim, num caso de mútuo, por exemplo, o direito do credor ao reembolso vem a ser a própria norma jurídica, que lhe garante a restituição da quantia mutuada; igualmente na propriedade, o direito do proprietário é a norma jurídica, em virtude da qual os demais indivíduos se adstringem a não interferir na maneira pela qual o primeiro dispõe do que é seu. Em resumo, finaliza Kelsen, direito subjetivo não é senão direito objetivo. Como diz Santamaria as teorias negativistas não fizeram senão provar ainda mais triunfalmente a existência dos direitos subjetivos. Com efeito, exprimem estes, em fórmulas ou palavras adequadas, uma situação verdadeiramente incontestável, ou seja, a possibilidade para cada um de nós de tornar efetiva, em certas circunstâncias, a coação social. Podemos assim conceituar o direito subjetivo como todo poder da vontade dos particulares, reconhecido ou outorgado pelo ordenamento jurídico." (Curso de Direito Civil - Parte Geral. $5^{\text {a }}$ edição. São Paulo: Saraiva. 1966, p. 10-11).

Lamentavelmente a impressão a que chega o leitor é que a definição eclética apresentada pelo professor Washington de Barros Monteiro ("direito subjetivo como todo poder da vontade dos particulares, reconhecido ou outorgado pelo ordenamento jurídico") é capaz de desagradar a todos e padecer de todos os defeitos que ele próprio encontra nas teorias que descreveu. 
pulsões, instintos, apetites, predisposto a obter aquilo que os satisfaz e em conflito com aqueles de outros indivíduos.

\section{d) "Função social" como "igualdade substantiva"}

Às três imagens superpostas, que nos deveriam conduzir a uma diplopia, sobrepõe-se mais uma ainda: aquela que enxerga no Direito Privado o retrato de relações de desigualdade. Em alguns conjuntos de normas, o reconhecimento e a imagem são evidentes, como naquelas expressamente protetivas de uma das partes (lembremos de nossos exemplos de sempre). Há dispositivos legais que reconheceriam expressamente a desigualdade, como o artigo 4. ${ }^{\circ}$, incisos I e II do Código de Proteção e Defesa do Consumidor: "reconhecimento da vulnerabilidade do consumidor no mercado de consumo" que conduz à "ação governamental no sentido de proteger efetivamente o consumidor". ${ }^{102}$ Outros a constroem a partir da técnica da "cominação de nulidade" (absoluta) de determinadas obrigações. No Código de Proteção e Defesa do Consumidor, por exemplo, o art. 51, incisos I, IV e XV traçam esse desenho:

Art. 51. São nulas de pleno direito, entre outras, as cláusulas contratuais relativas ao fornecimento de produtos e serviços que:

I - impossibilitem, exonerem ou atenuem a responsabilidade do fornecedor por vícios de qualquer natureza dos produtos e serviços ou impliquem renúncia ou disposição de direitos. Nas relações de consumo entre o fornecedor e o consumidor pessoa jurídica, a indenização poderá ser limitada, em situações justificáveis; [...]

IV - estabeleçam obrigações consideradas iníquas, abusivas, que coloquem o consumidor em desvantagem exagerada, ou sejam incompatíveis com a boa-fé ou a eqüidade; [...]

\footnotetext{
${ }^{102}$ O Código de Proteção e Defesa do Consumidor é um delicioso exemplo de reunião de todas as imagens até agora apresentadas. O caput do art. $4 .^{\circ}$ dispõe que: "A Política Nacional das Relações de Consumo tem por objetivo o atendimento das necessidades dos consumidores, o respeito à sua dignidade, saúde e segurança, a proteção de seus interesses econômicos, a melhoria da sua qualidade de vida, bem como a transparência e harmonia das relações de consumo, atendidos os seguintes princípios (...)". "Necessidades dos consumidores" remete a uma imagem utilitarista, tanto quanto a "proteção de seus interesses econômicos". "O respeito à sua dignidade, saúde e segurança" à máxima universalizável da ação (a "dignidade da pessoa") e a proteção das esferas de liberdade. "A transparência e harmonia das relações de consumo" revela o indivíduo virtuoso ("transparente" e que não dá azo à "desarmonia", atributos de uma personalidade "ética"). Finalmente, "a melhoria da sua qualidade de vida" (veja-se: não "da qualidade de vida", mas de "sua qualidade de vida") reconhece a situação efetiva de vulnerabilidade e a necessidade de proteção legal diferenciada. O inciso III do mesmo dispositivo é talvez ainda mais saboroso e deixamos essa sobremesa como exercício de análise: "III - harmonização dos interesses dos participantes das relações de consumo e compatibilização da proteção do consumidor com a necessidade de desenvolvimento econômico e tecnológico, de modo a viabilizar os princípios nos quais se funda a ordem econômica (art. 170, da Constituição Federal), sempre com base na boa-fé e equilíbrio nas relações entre consumidores e fornecedores".
} 
XV - estejam em desacordo com o sistema de proteção ao consumidor;

O dispositivo é tão claro que prescinde de maior análise. Atentemos apenas para a técnica legislativa: a cláusula é nula "de pleno direito", o que significa que prescindiria de declaração judicial. Além disso, não admite a convalidação, já que a "vontade" do consumidor é ignorada. Ainda que ele esteja plenamente de acordo em autorizar "o fornecedor a modificar unilateralmente o conteúdo ou a qualidade do contrato, após sua celebração" (inciso XIII) ou "a cancelar o contrato unilateralmente, sem que igual direito seja conferido ao consumidor" (inciso XI), sua concordância será inteiramente irrelevante. A lógica não é a da proteção individual, mas a proteção coletiva de indivíduos em posição de fraqueza relativa diante de outros indivíduos capazes de impor-se a eles. A imagem-narrativa é a do grande e do pequeno, a quem é necessário deter e a quem é necessário proteger ("reequilibrar", como se costuma preferir).

O correspondente dispositivo na Consolidação das Leis do Trabalho é o art. 444, talvez seu núcleo central:

Art. 444 - As relações contratuais de trabalho podem ser objeto de livre estipulação das partes interessadas em tudo quanto não contravenha às disposições de proteção ao trabalho, aos contratos coletivos que lhes sejam aplicáveis e às decisões das autoridades competentes.

A imagem que esse dispositivo revela a uma escavação que não exige profundidade é a seguinte:

Quando se fala em obrigações, no direito do trabalho, o que se quer dizer é que as condições de trabalho são preestabelecidas pelo legislador. Esta, todavia, deixa uma esfera para o ajuste de interesses ou de vontades entre os sujeitos da relação jurídica, o que nem sempre acontece, tendo em vista as características da situação que se forma numa empresa, na qual o contratante é o empregador, que paga os salários e está investido de poderes sobre a outra parte, e esta é um trabalhador subordinado que em troca do salário cumpre ordens. A desigualdade de posições dos sujeitos que figuram numa relação de emprego é manifesta, a tal ponto que o direito do trabalho surgiu exatamente para impedir que se agrave e fazer com que de algum modo a descompensação real seja mitigada pela intervenção jurídica no contrato de trabalho. As características imprimidas pelo referido texto legal ao contrato podem ser assim resumidas: a) a limitação da autonomia da vontade ou da esfera válida de interesses dos sujeitos contratantes, que podem estipular as cláusulas, expressas ou verbais, que julgarem do seu interesse, mas não terão validade aquelas que estiverem em desacordo com o ordenamento jurídico; b) a proteção do ordenamento jurídico ao trabalhador, tendo em vista o desnivel em que se acha, especialmente porque ao empregador são conferidos poderes sobre o empregado: os poderes de organização da atividade econômica em que irá prestar os seus serviços, o poder de regulamentar as rotinas dessa atividade, como horários de início e término do trabalho, uso de uniformes, momento dos intervalos de jornada e de descanso, dias de descanso semanal, valor dos 
salários, instruções sobre a forma como os serviços deverão ser prestados, poder disciplinar por meio de aplicação de penalidades, como advertência e suspensão etc. ${ }^{103}$

Os trechos grifados destacam a sobreposição de imagens que a dogmática traz para o primeiro plano da cena: "desigualdade de posições”, sim, mas ao lado da proteção por meio da "limitação da autonomia da vontade ou da esfera válida de interesses".

A imagem renasce no interior das análises que buscam na constitucionalização do "Direito Privado" (as aspas são, agora, óbvias) o "fundamento" da disciplina das relações privadas e o princípio de proteção da "igualdade substancial", ou "substantiva", ou "material". ${ }^{104}$ Tudo se passa como se a Constituição fosse uma norma que não exigisse interpretação (uma norma "padrão de medida"), ou melhor, cuja interpretação fosse evidente, e que, por ser formalmente considerada como ocupando o cume da hierarquia normativa, deveria também impor-se monarquicamente a todas as demais normas-súditos abaixo dela. Ora, como se crê que a Constituição — repitamos: uma norma "autoevidente" — protege as partes que, encontrando-se em relações de desigualdade, mostram-se vulneráveis, então

${ }^{103}$ Amauri Mascaro Nascimento, Curso de direito do trabalho: história e teoria geral do direito do trabalho: relações individuais e coletivas do trabalho (26. ed. São Paulo: Saraiva, 2011), 723-4, grifos meus. Não deixa de ser interessante notar que a leitura da legislação social, especialmente da CLT, revela um conjunto de imagens-narrativas como que a absorver o trabalhador no "capital fixo" da empresa. A quantificação contábil dos direitos trabalhistas faz com que o corpo se assemelhe à máquina que exige manutenção periódica (descanso semanal, limitação da jornada, férias), que se deprecia ou se danifica com o tempo (aposentadoria, auxílio-acidente ou auxílio-doença) e que precisa ser fabricada constantemente (proibição do trabalho infantil, condições diferenciadas para o aprendiz, proteção à maternidade, auxílio-desemprego). Numa era de precarização extrema do trabalho e de condenação à inexistência de populações inteiras, à margem do processo de produção e reprodução do capital, não deixa de ser curioso notar como a legislação trabalhista - descanso semanal, valor diferenciado da hora noturna ou limitação da jornada de trabalho -, ao prever cálculos contábeis precisos (o pagamento deve corresponder precisamente a horas e minutos), transpunha para o criador de parte do capital variável (correspondendo à compra do trabalho abstrato) o mesmo tratamento dispensado à parcela do capital constante correspondente às máquinas e equipamentos (que, na grande indústria, passa a subordinar-se às máquinas reais, o corpo integrando-se a elas como sua parte). $\mathrm{O}$ operário é máquina que opera outra máquina, e como tal é tratado. As indenizações correspondentes (horas extras, finais de semana não remunerados, etc.) o tornam "indene" na medida em que o "reparam" (manutenção e conservação da máquina, que se gasta e se deprecia: "tutela reparatória do dano"). Tornada crescentemente irrelevante para esse sujeito automático de acumulação, resta sua precarização e sua crescente (e incômoda) irrelevância. Sobre os efeitos da precarização como resultado da autonomia financeira virtual do capital financeiro há uma vasta e crescente literatura. Remeto apenas, entre os muitos, para os excelentes ensaios reunidos por Francisco de Oliveira, Ruy Braga e Cibele Saliba Rizek (orgs.), Hegemonia às avessas: Economia, política e cultura na era da servidão financeira. (São Paulo: Boitempo, 2010).

${ }^{104} \mathrm{O}$ principal defensor dessa visão é, como sabemos, o professor Gustavo Tepedino. Para uma síntese de sua visão, e mesmo do projeto de constitucionalização geral do direito, vejam-se estes dois textos do professor Gustavo Tepedino: "Normas Constitucionais e Direito Civil na Construção Unitária do Ordenamento" (In: Daniel Sarmento e Cláudio Pereira de Souza Neto (orgs.). A Constitucionalização do Direito: Fundamentos Teóricos e Aplicações Especificas. Rio de Janeiro: Lumen Juris, 2007), p. 309-320 e "Premissas Metodológicas para a Constitucionalização do Direito Civil" (In: Temas de Direito Civil. 
essa "rocha firme e sólida" imporia ao próprio Código Civil uma releitura que o tornaria uma norma protetiva de partes em posição de vulnerabilidade. Tudo ocorreria, então, a partir daí, da seguinte maneira:

É nítida, pois, a superação da dicotomia direito público e privado, vislumbrando-se em alguns ramos da ciência jurídica pontos comuns, de contato, com um e outro ramo. Esse fenômeno é resultado do avanço da sociedade, com relações complexas e plurais e, principalmente, da constitucionalização do Direito Civil, com a previsão, em sede constitucional, de matérias até então relegadas à legislação civil ordinária. Ora, ao disciplinar diversos institutos nitidamente civilistas (como a família, a propriedade, o contrato, dentre outros), o legislador constituinte redimensionou a norma privada, fixando os parâmetros fundamentais interpretativos. Em outras palavras, ao reunificar o sistema jurídico em seu eixo fundamental (vértice axiológico), estabelecendo como princípios norteadores da República Federativa do Brasil a dignidade da pessoa humana (art. $1^{\circ}$, III), a solidariedade social $\left(\right.$ art. $3^{\circ}$ ) e a igualdade substancial (arts. $3^{\circ}$ e $5^{\circ}$ ), além da erradicação da pobreza e redução das desigualdades sociais, promovendo o bem de todos (art. $3^{\circ}$, III e IV), a Lex Fundamentallis [sic] de 1988 realizou uma interpenetração do direito público e do direito privado, redefinindo os seus espaços, até então estanques e isolados. Tanto o direito público quanto o privado devem obediência aos princípios fundamentais constitucionais, que deixam de ser neutros, visando ressaltar a prevalência do bem-estar da pessoa humana. Lembrando a interessante metáfora de Nélson Saldanha, reportando-se ao "jardim e à praça" como referência aos espaços privado e público, respectivamente, é esclarecedor o magistério de Daniel Sarmento sustentando que a "clivagem tradicional se relativizou" e que "o cenário das relações privadas dificilmente tem as características idílicas de um aprazível jardim. Trata-se antes de uma arena povoada por conflitos deflagrados ou latentes, entre partes freqüentemente desiguais". Exatamente por isso, Luiz Edson Fachin, grande referência da nova fase do Direito Civil brasileiro, vislumbra uma verdadeira "virada de Copérnico" [sic] no Direito Privado, reunificando, ao derredor dos valores existenciais da pessoa humana, um sistema que estava fragmentado por um número infindável de leis. ${ }^{105}$

$3^{\text {a }}$ edição. Rio de Janeiro: Renovar, 2004), p. 2-22.

${ }^{105}$ Cristiano Chaves de Farias e Nelson Rosenvald, Curso de Direito Civil - Teoria Geral, op. cit., p. 39-40. O binômio solidariedade social-igualdade substantiva é repetido monotonamente até a exaustão por esses autores. A interpretação a partir dele não é neutra, como se poderia acreditar, diversamente do que acontece frequentemente com novidades doutrinárias anódinas que terminam por manter com novas premissas o que já ficava sozinho de pé. Um exemplo interessante: a rejeição, por inconstitucionalidade, do inciso VII do art. $3^{\circ}$ da Lei $n^{\circ}$ 8.009/90 (penhorabilidade do bem de família do fiador de contrato de locação de imóvel urbano). "É que os bens - móveis ou imóveis, eventualmente existentes - do locatário (o devedor principal) não poderão ser penhorados, uma vez que incidirá sobre eles a impenhorabilidade legal, em conformidade com o art. $1^{\circ}$ da lei protetiva. Ora, se a lei, que não permite a penhora do bem de família do devedor principal, vai permitir (inciso VII, art. $3^{\circ}$ ) a penhora do imóvel que serve de moradia para o fiador, viola flagrantemente a igualdade substancial constitucional, maculando na inteireza o inciso referido. Por isso, há total incompatibilidade da norma legal com a Constituição Federal, seja porque a mesma é incompatível com a proteção jusfundamental à moradia, seja em razão da quebra da igualdade substancial, tratando diferentemente devedores originados pela mesma causa." (p. 600). O argumento, rejeitado pelo STF, parece-me convincente "do ponto de vista técnico-jurídico" (se a esta altura ainda me é permitido o emprego da expressão sem contradição), mas por outras premissas: é que, a pensar o contrário, o locatário que eventualmente fosse proprietário de imóvel protegido como bem de família estaria resguardado, pois a lei só prevê a penhorabilidade do imóvel do fiador. O que constitui um evidente paradoxo e, como sabemos, a exegese deve presumir que "o legislador é racional". 
Surge aí, então, a imagem de um "Direito Privado" (o sic agora é para mim mesmo) que defende e socorre o fragilizado, o fraco, o impotente. Há ainda indivíduos - o personagem abstrato de sempre - , mas cujas posições recíprocas os fazem desiguais. Sobre o palimpsesto do indivíduo autônomo, autointeressado e virtuoso emprega-se o carimbo da "igualdade substancial" e apõe-se a chancela do vulnerável.

\section{Retratos ou retrato?}

Surgiria agora uma questão: não haverá outras tantas figuras que coordenariam o Direito Privado além dessas que fizemos notar? A questão deve ser devolvida ao adversário, que nos pede, na verdade, a demonstração de um teorema de completude. A objeção de que seria necessário demonstrar que o quadro está completo deve ser respondida não só pedindo ao adversário que nos indique outras figuras, mas também lhe perguntando se, para a demonstração, isso realmente é necessário.

$\mathrm{Na}$ verdade, o que mais importa é destacar as imagens e a composição do quadro. E não se trata de uma composição, em que os diferentes personagens ocupariam campos diversos da tela. Não temos, como no monumental retábulo de Jan van Eyck, A Adoração do Cordeiro Místico, nos cantos superiores esquerdo e direito, Adão e Eva, isolados e nus, sobre os quais se inscrevem cenas de Caim e Abel; no centro, a Virgem Maria, Deus e João Batista; em baixo, à esquerda, os Justos Juízes e os Soldados de Cristo, e à direita os Eremitas e os Peregrinos sagrados; todos circundando a cena central, que descreve o Juízo Final: os mártires do sexo masculino, os escritores pagãos e profetas judeus, os santos do sexo masculino e as mártires do sexo feminino rodeando o Cordeiro Místico. Embora o observador tenha de focar sua atenção em figuras isoladas, elas são nítidas e compõem uma narrativa: a da história da humanidade, do início ao fim dos tempos. A unidade da narrativa não lhe é exterior, ainda que as imagens estejam separadas no políptico.

A primeira característica desse conjunto de imagens é que elas não compõem uma figura unitária. Se a unidade existe, como se pode notar dos textos acima que nos serviram de ilustração, o que se nota é a justaposição de imagens que não necessariamente compõem um quadro dotado de unidade. Não se está, por exemplo, diante do retrato típico da família burguesa do século XIX: pai ao centro, mãe ao lado, e os muitos filhos, numa fotografia em preto e branco em que ao patriarca e à mulher são designados papéis claros e bem definidos, tanto quanto às crianças, que assim permanecerão até a idade adulta, pois não se concebia nem a adolescência, nem a juventude. Nessa fotografia, o quadro é claro, ainda 
que cada figura tenha sua identidade; ainda assim, é na diferença com as demais que elas emergem. O homem virtuoso, diversamente desse retrato, não está "ao lado" do indivíduo autônomo, que estaria ao lado do átomo autointeressado, que ladearia o homem desigual. Embora os textos jurídicos (legais e doutrinários) os justaponham, essa justaposição não compõe um sistema de diferenças de que surge uma unidade. Antes, tudo se passa como se o observador passeasse a atenção de um objeto a outro sem que a unidade seja evidente.

A segunda característica é a imprecisão e a vagueza. Cada uma delas, como vimos, organiza um relato que permanece subentendido. Bons textos de dogmática ou a fundamentação de sentenças e acórdãos freqüentemente detalham tais narrativas, mas ao mesmo tempo as justapõem sem que, curiosamente, notem que são inconciliáveis. É assim que há uma história pressuposta cujos episódios por vezes são contados nesses textos: o do indivíduo que ponderou antes de contratar, que não foi compelido a tanto por nada nem ninguém, e que se obriga a responder, agora, pela palavra emprenhada. Ao lado dessa narrativa aflora outra: a de que o descumprimento do contrato firmado não só alcança as partes, mas também terá reflexos mais amplos, desestimulando os agentes econômicos a produzirem ou tornando mais caros seus produtos e serviços em razão do incremento do risco. A narrativa pressuposta, portanto, avança e recua no tempo: os indivíduos que ponderaram racionalmente seus interesses no momento de contratar e, posteriormente, o descumprimento do contrato, a pedra lançada ao lago cujas ondas alcançam pontos cada vez mais distantes. E assim prosseguem elas, não num romance "em cadeia" como diria Dworkin, mas numa coletânea de contos em que tudo se passa como se o leitor estivesse diante de um novo texto.

No entanto, se na doutrina e nas decisões as imagens se justapõem, sua característica essencial é antes a sobreposição. A mera justaposição, lado a lado, deveria terminar por exibir a incompatibilidade das imagens. Mas isso não ocorre. Daí o duplo fenômeno: de um lado, a narrativa é subentendida, só vem à tona aos poucos, parcialmente e nunca por inteiro. De outro, ela esfumaça a imagem, que agora perde a nitidez. É assim que a unidade é alcançada antes pela diminuição de sua resolução, pelo apagamento das arestas e pela perda de sua possível nitidez. Tais elementos não são simplesmente suprimidos, mas são lançados para segundo plano, reprimidos. É o que permite a existência de um texto em que todas essas imagens aparecem ao mesmo tempo, ao lado uma da outra, seqüencialmente, sem constrangimento ou embaraço. Tudo se passa, agora, como se a narrativa fosse única, descrevendo um único indivíduo proteiforme, ora destacando mais, ora menos seus traços 
de autonomia, eficiência, honestidade e, por vezes, preponderância ou desigualdade. A construção da imagem, assim, faz-se pela supressão para um segundo plano daquilo que tornaria as narrativas visivelmente inconsistentes, levantaria suspeitas e causaria perplexidade. Que levaria, do contrário, ao colapso a ilusão ideologia do direito, tanto na representação que guia sua atividade quanto em seu produto final.

Aqui uma observação. István Mészáros distinguiu entre a metáfora, cujos receios e perigos podem ser encontrados no uso que Heidegger dela faz, e o símile, que não recorreria a subterfúgios:

Um exemplo importante da transformação de uma metáfora em símile, na história da filosofia, é o desenvolvimento da teoria do "contrato social", pois um contrato sem partes realmente contratantes não é nada mais que uma metáfora. Tomada literalmente no contexto filosófico, ela é muito ingênua e não tem qualquer peso. Por outro lado, as tentativas que visam eliminar as dificuldades conceituais, causadas pelo tratamento literal dessa metáfora, levam a excentricidades conceituais (tais como o "consenso tácito" de Locke, por exemplo) isso porque elas mesmas retêm a ficção metafórica de um contrato (não consensual).

A situação muda radicalmente quando a prescrição "como se" é introduzida na teoria do contrato. Tão logo isso é feito, a teoria do contrato deixa de ser metáfora e se transforma em símile. A função conceitual deste símile é claramente normativa. Dizer que um país deve ser governado "como se" a autoridade fosse derivada de um contrato social é estabelecer certas normas de conduta relacionadas a alguns valores humanos fundamentais (liberdade, igualdade, justiça etc.). O símile funciona como um modelo de ação ligado a um conjunto de valores. Ocupa, assim, o lugar de um intermediário normativo, entre os tipos de ação que defende (por exemplo, a legislação de certo tipo e o comportamento de ambas as partes ligadas pelo contrato, de acordo com a referida legislação) e os próprios valores nos quais, supostamente, essas ações estejam baseadas. Como modelo de ação, o símile normativo retoma os valores cujas implicações práticas se tornam mais ou menos explícitas, e, estimulando as ações particulares, estabelece seu quadro global de orientação, bem como indica seu âmbito de compatibilidade de acordo com os valores admitidos. ${ }^{106}$

As imagens-narrativas do direito não constituem símiles, no sentido que Mészáros atribui a essa palavra. Não constituem um “como se”, pois se assim fossem perderiam a pretensão de descrever a realidade diretamente. Tais imagens-narrativas do direito supõem-se como uma descrição do homem tal como é e como deve ser. Mais próximas das metáforas do que do símile, a superposição de imagens se apresenta como real, não como um intermediário discursivo necessariamente incômodo, mas que infelizmente precisaria ser tolerado para a apreensão da realidade.

Que nos seja permitida uma divagação.

${ }^{106}$ István Mészáros, Filosofia. ideologia e ciência social (São Paulo: Boitempo, 2008), p. 199. 
Velásquez pinta em 1650 o retrato do papa Inocêncio X. É nítido olhar autoritário e vingativo da personagem que perseguiu os Jansenistas e fez o que pôde para impedir a Paz de Vestfália. A nitidez tanto das cores, contrastando o púrpura da casula com o branco da bata branca, quanto dos traços do rosto, do corpo e especialmente das mãos, opõe-se a sua revisão pelo pintor Francis Bacon nos quarenta e cinco Estudos sobre Velásquez que produziu nos anos cinqüenta do século passado. ${ }^{107}$ A primeira característica notável dessa série chocante, que toma como base aquele quadro de Velásquez, é a perda da nitidez. No Estudo n. I, de 1950, por exemplo, uma série de franjas verticais brancas e pretas esbatidas são superpostas sobre a imagem que, ela própria, já perdeu inteiramente a nitidez (aliás, a casula tornou-se roxa, e a bata branca reduziu-se a uma mancha). No Estudo de 1953, talvez o mais conhecido, já não é possível sequer identificar os dedos (apenas as mãos), o nariz, a orelha, e olhos, meras manchas de tinta, só são reconhecidos por nós pela posição em que se situam no rosto. A boca abre-se num riso ou grito sinistro que passará a caracterizar a série. Como em outros quadros de Bacon, a escuridão e especialmente o esbatimento da grossa pincelada contribuem, ou talvez sejam o traço mais notável, de uma perda da precisão da imagem cujo poder expressivo é tanto maior à medida que se tornam mais imprecisos os detalhes essenciais do quadro de Velásquez. O mesmo processo, guardados os limites da analogia, reconhecemos nas imagens-narrativas do homo jusprivatisticus: superposição, perda da nitidez, omissão, silêncio.

Já fomos muito longe nas metáforas e analogias. O essencial é guardarmos que as quatro imagens só asseguram uma narrativa única na medida em que suas narrativas parciais são privadas de elementos essenciais, que permanecem, aquém do expresso no discurso jurídico, ignorados, mas não porque desconhecidos. Forma-se uma abstração (poliforme) do indivíduo, que pode desempenhar todos os personagens porque a consistência de suas narrativas parciais é mutilada. Restará saber de que forma isso ocorre.

A crítica que o rigor filosófico (especialmente da filosofia do direito, com muita freqüência expressando um vezo aristocrático contra a dogmática jurídica) costuma lançar a esse fenômeno discursivo erra o alvo. O ecletismo das imagens não decorre da falta de coe-

\footnotetext{
${ }^{107}$ Gilles Deleuze em Francis Bacon, logique de la sensation (Paris: La Différence, 1981) comenta as duas obras. Mas aqui não queremos de modo nenhum ir tão longe quanto ele, nem estamos propondo uma "essência histérica da pintura, em nome de uma clínica puramente estética e independente de toda psiquiatria, de toda psicanálise", quando Bacon decide tomar Velásquez como mestre. Nosso propósito é infinitamente mais modesto: atentar apenas para o esbatimento que se revela no contraste entre as duas formas figurativas de que as duas pinturas nos servem de modelo.
} 
rência, de engenho ou de acuidade, ou mesmo de um pendor retoricamente superficial daqueles que "aplicam" o direito, ou melhor, o "praticam". É preciso examinar o fenômeno antes na sua positividade e dar-lhe crédito. A saber: é preciso antes perguntar se tal característica, a aparente superficialidade, não é o traço essencial do próprio Direito Privado como prática de poder.

IV. Inércia instuticional, "comunidade interpretativa” e autorreferencialidade doutrinária

Essa imagem do indivíduo, indecisa e marcada pela indefinição, remete-nos para os mecanismos socioinstitucionais que a produzem e alimentam. Se a produção textual jurídica que abrange a produção normativa tradicionalmente classificada como "primária" (a norma "emanada do legislador") ou "secundária" (sua "aplicação aos fatos", na forma de um parecer administrativo, ou uma petição, ou uma decisão judicial) é norteada pela fantasmagoria dessa narrativa do indivíduo, o que a nutre e a mantém? Textos jurídicos, no sentido mais amplo possível da expressão como a que acabamos de empregar, são produtos da prática jurídica. A partir deles é possível revelar que sua produção foi guiada por essa fantasmagoria, mas isso os torna apenas produtos finais da práxis que ela orienta. A pergunta agora é o que, em termos ainda apenas propriamente institucionais, sustenta tais objetos textuais.

A primeira resposta é a inércia da tradição jurídica. O fenômeno, para o qual Dworkin chamou a atenção à sua maneira, tem de ser observado, porém, por um ângulo mais amplo. Em primeiro lugar, o decisionismo de que a tradição positivista nunca conseguiu se desvencilhar, supõe a possibilidade de uma fundação inteiramente inaugural do direito, visto como sistema de normas. Se, afinal, a norma jurídica não possui um fundamento "exterior" ao próprio sistema, nada impediria (exceto, talvez, alguns fatos contingentes, como as características mais inafastáveis do corpo humano) que uma revolução jurídica acontecesse, instaurando um sistema normativo inteiramente novo. Sabemos que os primeiros (e ao mesmo tempo últimos, infelizmente) grandes filósofos do direito soviéticos se deram conta de que as coisas não seriam assim tão simples. ${ }^{108}$ E nem mesmo o maior estudioso do direi-

\footnotetext{
${ }^{108}$ Tanto Paschukanis quanto Stuchka, colaboradores, mas críticos recíprocos, insistiram na necessidade de um "período de transição" de uma forma de direito para outra. Esses dois autores, como já pudemos insistir anteriormente, apesar da encantadora e de longe invulgar análise do direito que elaboraram, ain-
} 
to sob estado de exceção, Carl Schmitt, deixou de atentar para o fato de que o comando imposto por aquele que decide nessas condições tem de ser compreendido pelos seus destinatários, pois assume a forma de um ato linguístico.

Se focalizarmos, pela tradicional "Teoria das Fontes do Direito", a produção normativa dita "primária", verificaremos que o fenômeno da revogação cria uma falsa ilusão de total novidade, o que é, visto com mais profundidade, inteiramente falso. Tomemos como exemplo um código, como o Code Napoléon ou mesmo o Código Civil de 2002. Aparentemente, o Código Civil francês impôs uma nova ordem normativa, estabeleceu verticalmente o direito nas relações privadas e conferiu, por um ato de poder, "forma" a uma "matéria" social perfeitamente plástica. A história daquela codificação, porém, revela não só a hesitação (os três projetos anteriores de Cambacérès foram rejeitados) e sua antecipação por leis que uniformizaram (em vez de simplesmente instaurar) aspectos essenciais de institutos como casamento, herança e transferência de propriedade, mas, essencialmente, a intenção de compatibilizar o que já existia. A comissão de Portalis, se por um lado abria finalmente a "Era das Codificações" nessa "Era das Revoluções", como a descreveu Eric Hobsbawn, por outro tinha de buscar o já existente em seu esforço de padronização. É assim que o direito francês de da época, apesar de dividido geograficamente em duas regiões (direito costumeiro e direito escrito), serviu de base para a codificação, muito mais uniformizando territorialmente o direito que impondo um direito novo, como mostram os estudos da elaboração histórica desse código. ${ }^{109}$

Ao lado desse fenômeno de base, em que normas que pareceriam inaugurar ordens jurídicas novas se mostram muitíssimo mais despretensiosas, confessando muito mais or-

da assim não conseguiram deixar de conceber o direito a partir de seu produto, ou seja, de vê-lo como um sistema de normas cuja estrutura mais elementar, a forma jurídica, reflete a forma-mercadoria, ou ainda a forma das relações sociais de produção. Eis o pressuposto metodológico de base de que é preciso se afastar.

${ }^{109}$ A esse respeito, veja-se Raoul Van Caenegem, Uma Introdução Histórica ao Direito Privado (São Paulo: Martins Fontes, 2000), p. 1-19. Van Caenegem está entre os mais sensíveis a esse fenômeno: o de que a codificação não nasce do nada. Antes, ela uniformiza (e, claro, na uniformização há escolhas, o que é óbvio) práticas jurídicas e não consegue ser produto de uma decisão inteiramente inaugural do legislador. O supervisor da Comissão de Redação do Código Civil de 2002, o professor Miguel Reale, na Exposição de Motivos do projeto, é franco quanto à diretriz que foi tomada: "Preservar, sempre que possível, a redação da atual Lei Civil, por se não justificar a mudança de seu texto, a não ser como decorrência de alterações de fundo, ou em virtude das variações semânticas ocorridas no decorrer de mais de meio século de vigência. [...] Não dar guarida no Código senão aos institutos e soluções normativas já dotados de certa sedimentação e estabilidade, deixando para a legislação aditiva a disciplina de questões ainda objeto de fortes dúvidas e contrastes, em virtude de mutações sociais em curso, ou na dependência de mais claras colocações doutrinárias, ou ainda quando fossem previsíveis alterações sucessivas 
ganizar relações jurídicas anteriores e, se alguma coisa estruturam, é pela escolha entre as alternativas, é preciso acrescentar a inércia interna ao próprio direito. Normas mais comezinhas, como as que alteram um dispositivo ou uma norma inteira, mas não reestruturam um "campo" inteiro do direito, apresentam-se inseridas num fluxo que não só restringe suas possibilidades, mas exige dela a manutenção do que lhe foi transmitido. E isso não porque não deve ser "inconsistente" com as demais normas pertencentes ao sistema. Antes, pelo fato de que, como produto, para que possa realmente governar a decisão que será tomada por meio dela, não pode entrar em conflito frontal com as demais representações que guiam a produção do direito. Uma comissão de professores encarregada de elaborar um anteprojeto de lei, ou simplesmente um simples consultor jurídico lotado em algum órgão com a tarefa de elaborar a minuta de uma norma, os concebe a partir do já disponível, ponderando efeitos da nova norma e redigindo-a a partir de uma certa imagem social. ${ }^{110}$ Foi assim com a redação do Código de Proteção e Defesa do Consumidor atual, ainda que a comissão se tenha valido de normas estrangeiras para elaborar o nosso. E é ainda assim atualmente em seus três projetos de reforma. É antes uma representação social, nascida da leitura das normas, que permite elaborar novas normas que, por sua vez, reforçarão ou modificarão a mesma representação social que guiou a produção jurídica primária. Não o contrário, como pressupõe sem problematizar a tradição positivista, presa àquilo que Foucault denunciava como a "representação monárquica do poder". ${ }^{111}$

\footnotetext{
para adaptações da lei à experiência social e econômica."

${ }^{110}$ A ilusão platônica de uma razão que se impusesse politicamente à vida social, de fora e de cima desta, é perfeitamente reconhecível aqui. A esse respeito, veja-se Tércio Sampaio Ferraz Júnior, Função Social da Dogmática Jurídica, p. 20-22.

${ }^{111}$ Veja-se, particularmente, a esse respeito, Michel Foucault, História da Sexualidade I: a vontade de saber (Rio de Janeiro: Edições Graal, 1988), p. 79-87, Microfisisica do poder (Rio de Janeiro: Graal, 1979) e $A$ Verdade e as formas jurídicas (Rio de Janeiro: Nau, 1996). Mas Foucault caricaturiza o "marxismo universitário" europeu ao afirmar que ele suporia que as condições econômicas, sociais e políticas da existência nada mais fariam do que "depositar-se ou imprimir-se nesse sujeito definitivamente dado" (p. 8). Ou ignora, ou finge ignorar todo o debate que, desde o Prefácio à Contribuição à Crítica da Economia Política (texto que não é, diga-se de passagem, nem um pouco óbvio, mas ambíguo, sinuoso e cheio de meandros interpretativos possíveis), passando pela célebre carta a Bloch, passando por Gramsci, Lukács, Benjamin e Adorno, e alcançando finalmente a teoria literária angloamericana e francesa, rejeitaram há muito tempo o esquema simplificador da suposta "redução" da "superestrutura" à "infraestrutura". Não obstante, a denúncia de Foucault da representação monárquica do poder, associada à soberania como sua contraparte jurídico-política, corresponde a uma representação que lhe confere eficácia na precisa medida em que esconde seus mecanismos reais. "O poder seria aceito se fosse inteiramente cínico?", pergunta Foucault. A pergunta é essencial e Foucault sabe bem a quem está respondendo. Pois é a mesma pergunta que deve ser feita ao direito, mas respondendo a Foucault: se a representação que o guia e informa se confessasse como tal, em seu papel ideológico (conceito que, sabemos, Foucault não aceita), o direito como prática de poder ainda seria possível?
} 
Ao lado dessa inércia institucional há ainda, em segundo lugar, a própria inércia da formação jurídica que possibilita o próprio significado do texto. ${ }^{112}$ É para ela, como chamou a atenção Stanley Fish, e não para um essencialismo semântico e tampouco para uma "tradição interpretativa", como quer Dworkin, que devemos voltar-nos se pretendemos compreender como um texto jurídico (no sentido mais amplo possível dessa palavra, ou seja, como resultado de uma atividade de que é produto, e não o contrário) pode adquirir sentido. ${ }^{113} \mathrm{O}$ processo de socialização básica do "operador" ou "aplicador" (as aspas são essenciais) do direito inicia-se a partir do momento em que, ingressando no curso em que será formado, é treinado para identificar um conjunto de textos e práticas como pertencentes ao direito. Tal identificação, ao contrário do que possa parecer (especialmente se ainda continuarmos assentados no pico da colina positivista), não deriva de algum critério lógico, como o eventual pertencimento da regra a uma cadeia de produção de regras, ou seja, de seu "pedigree". Um estudante de direito sabe que está diante de um texto jurídico porque ele é editado por certa editora conhecida, porque foi coordenado por certo professor, ou porque apresenta o que teria sido publicado em outro repertório de textos (que ele aprendeu que existe): o Diário Oficial. Um estudante mais avançado, ou um Ministro do STF, não reconhecerão Memórias Póstumas de Brás Cubas como um texto jurídico não porque não se apóie numa cadeia normativa, mas antes porque seu autor é um literato, sua editora não pertence às tradicionais conhecidas, sua forma de redação não é aforismática (não se

${ }^{112}$ Duncan Kennedy destacou, em seu célebre artigo "Legal Education and the Reproduction of Hierarchy" (veja-se o debate em Legal Education and the Reproduction of Hierarchy: a polemic against the system: a critical edition. Nova York: New York University Press, 2004), como os alunos de direito, já no primeiro ano de uma universidade americana, são submetidos e modelados por práticas educacionais e a um currículo preestabelecido, tudo para que aprendam a "pensar como um jurista":

"Os professores de direito modelam para os estudantes como se supõe que devam pensar, sentir e agir nos seus papéis profissionais futuros. Um pouco disto decorre do ensino através de exemplos; um pouco, decorre de um aprendizado mais ativo de interações que são uma espécie de educação clínica para o comportamento com jeito de jurídico. Esse treinamento é um fator principal na vida hierárquica da advocacia. Codifica a mensagem da legitimação do sistema como um todo nos seus mínimos detalhes de estilo pessoal, rotina legal, gestos, tom de voz, expressão facial, uma pletora de pequenos Ps e Qs para qualquer um pensar. Em parte, servirão como uma linguagem - um modo para o jovem advogado de transmitir que ele sabe o que são as regras do jogo e pretende jogar com elas. Em parte, decorre de juramentos e afirmações ritualizados - adotando os maneirismos consegue-se uma jura de fidelidade com a desigualdade. E parcialmente é uma questão substantiva de valor. $\mathrm{O}$ comportamento hierárquico voltará a expressar-se e realizar os egos hierárquicos de pessoas que eram inicialmente apenas portadores de máscaras.” (p. 602-603).

${ }^{113}$ Fish é um autor rico e fascinante, mas não é necessário admitir nem todas suas conclusões, menos ainda todos seus pressupostos. O conceito que nos interessa é o de "comunidades interpretativas", que, como sabemos, Fish traz da teoria literária para a filosofia do direito. A esse respeito, o clássico Is there a text in this class? (Harvard: Harvard University Press, 2002), p. 338-355. 
apresenta sob a forma de uma seqüência de frases, os chamados "dispositivos legais"). ${ }^{114} \mathrm{O}$ passo seguinte é passar a aprender uma linguagem e uma forma de representar a vida social. O significado do texto legal depende de uma série de práticas que são presenciadas no meio jurídico-acadêmico: discursos moralizantes; descrições com maior ou menor carga de preconceito acerca de indivíduos, grupos e classes; exortações cafonas e juízos de valor cheios de boas intenções; descrições da vida social mais ou menos acuradas, mais ou menos distorcidas; apresentações de narrativas históricas e fatos exemplares; autores que possuem autoridade e merecem a leitura, contrastados com aqueles que devem ser objeto de desprezo; decisões políticas e judiciais paradigmáticas.

O significado do texto, bem como sua produção (eis o ponto mais importante), apóiase e decorre da formação, assim, de uma comunidade interpretativa. A comunidade interpretativa jurídica, assim formada, é o padrão que permite decidir não só entre o que pertence e o que não pertence ao direito (um livro de receitas e um texto legal, ainda que ambos tenham em comum comandos normativos na forma "faça" ou "não faça"), e o que constitui uma interpretação aceita pela comunidade e aquelas que não o são. Os textos normativos são, assim, apenas mais uma espécie de textos que, aliás, não possuem nem significado, nem vida própria (ainda que, como veremos adiante, lhes seja essencial aparecerem como autônomos), só existindo como tais e só ganhando sentido na medida em que constituem apenas mais um elemento textual de uma prática interpretativa da comunidade jurídica.

A prática jurídica, assim compreendida, nasce no interior de uma comunidade interpretativa cujos contornos podem ser mais ou menos amplos (a prática jurídica penal ou militar é mais restrita do que a civilista ou consumerista, para utilizarmos categorias que devem, agora, revelar sua verdadeira natureza). O treinamento daquele que lidará com o direito, portanto, consiste essencialmente em ser iniciado a tais práticas interpretativas da comunidade e no desenvolvimento um modo de encarar a vida social. Essa "forma da consciência social", para voltarmos ao conceito clássico, é um produto primário dessa formação que envolve hierarquias, elaboração de identidades e diferenças, estabelecimento de limites e regras de absorção e exclusão, e até mesmo práticas de conduta e a disciplina do

\footnotetext{
${ }^{114}$ O Tractatus, de Wittgenstein, se deixado sobre a mesa de um juiz que desconhecesse a língua alemã, talvez lhe fizesse passar pela peça que se cuida de um exemplar do Código Penal austríaco, pela disposição gráfica do texto. O mesmo ocorreria com a Ética de Espinosa: seria um Código Civil holandês comentado por algum doutrinador, se estivesse nessa língua e fossem suprimidos o nome do autor e o título da obra.
} 
corpo (da roupa ou cabelo ao formalismo da linguagem verbal). ${ }^{115}$ Digamos, para traduzirmos na linguagem de Pierre Bourdieu — mas, por favor, sem maior compromisso-, que a comunidade constitui um campo e produz em seus participantes um habitus, uma do$x a$ e finalmente uma illusio. Na nossa terminologia: uma comunidade jurídica executora de práticas guiadas por uma representação pela qual a sociedade lhe é apresentada.

É o que explica, por fim, um fenômeno curioso e que deveria ter chamado mais a atenção da família positivista: a autorreferencialidade da dogmática jurídica. Os "doutrinadores" (o equivalente, no campo da história da filosofia, aos "comentadores") do direito desempenhariam a função, conforme correntemente se entende, de sistematizá-lo, interpretar as normas que não fossem claras (in claris cessat interpretatio), servir de depositório da história do direito..., e só. Seu foco de atenção, portanto, deveria ser a norma, a norma e nada mais do que a norma. Não é o que ocorre, sabemos bem. Os melhores doutrinadores — e aqui "melhores" não é, de maneira nenhuma, uma ironia ${ }^{116}$ — elaboram seus trabalhos referindo-se menos ao texto legal do que a outras obras de dogmática, antecedentes ou contemporâneas. Tudo se passa como se a dogmática ganhasse autonomia, como se o Golem tivesse realmente ganhado vida e prescindisse do texto normativo que, agora, se torna um texto a mais (ainda que, é claro, isso nunca seja admitido). O texto normativo aparece como aforisma que serve apenas de pretexto para uma narrativa onde são chamados ao diálogo outros doutrinadores, o passado do direito, a multiplicação cuidadosa das distinções e, sobretudo, a elaboração de uma figuração implícita da realidade social. Se a comunidade jurídica interpretativa é a que constitui o direito com suas práticas, são os textos doutrinários, muito mais do que o texto legal positivo, que elaboram essa representação. ${ }^{117} \mathrm{~A}$ dog-

115 O que não equivale a um "ceticismo de regras", no sentido de Karl Llewellyn. A proposta não é reduzir a norma ao comportamento dos atores jurídicos, mas fazer ver que o texto, como produto de uma práxis social de exercício do poder, realimenta uma comunidade interpretativa cujas práticas hermenêuticas as mais amplas possíveis são as que lhe conferem sentido.

${ }^{116}$ A aparente ironia desaparece se contrastarmos a melhor doutrina com a pior. Curiosamente, a pior doutrina restringe-se à paráfrase de textos legais, a remeter a outros textos ou, agora no último porão do inferno, a "sistematizar" para auxiliar a memorização didática do direito positivo. Em contraste, a melhor doutrina tradicional esmera-se em formular distinções e classificações, construir "teorias" e arquivar a memória histórica do direito. Não é pouco, convenhamos. Mas talvez seja necessário opor a essa doutrina tradicional uma outra, que chamarei de "superior", na falta de algum termo melhor, e que problematiza a aplicação da norma, desconstrói a imagem que ela lança sobre a realidade, informa sobre as condições político-sociais de seu nascimento em profundidade e a opõe à realidade que visa disciplinar. Sem lançar fora um trabalho analítico tradicional, essa doutrina retorna ao texto normativo para não só não sair da jaula, mas também lançar-se além e para fora da própria norma.

${ }^{117}$ Vale a pena notar que um autor, de resto bastante sensível ao papel da doutrina como produtora ideológica, como Luís Alberto Warat, ainda permanece preso a uma concepção nomocêntrica do direito. É 
mática fecha-se assim numa "jaula de aço", uma feliz (e triste) expressão que Max Weber utilizou num contexto inteiramente diferente. ${ }^{118}$ Ela encerra-se em si própria, num borbotão de citações e referências que quase chegam a transformá-la num sistema autopoíetico luhmanniano. Mas o fluxo textual autorreferencial responde por boa parte da construção dessa representação da realidade social. ${ }^{119}$ Se é inegável a existência de uma inércia institucional normativa, por outro lado é a narrativa doutrinária a principal responsável por nutrir a comunidade interpretativa jurídica e permite não só a concessão de sentido aos textos normativos primários, como até mesmo sua elaboração.

A mesma autorreferencialidade, ainda que num grau menor, encontramos cada vez mais naquele conjunto textual que abrange as decisões administrativas e jurisprudenciais.

assim que ele oscila entre uma concepção absolutamente clássica do papel da dogmática (estruturadora de teorias conceituais), cabendo-lhe a interpretação da norma, ora dotada de um sentido que the cabe apenas sistematizar, ora cabendo atribuir-lhe um outro, e uma visão da dogmática como formadora da ideologia do direito, inclusive como barreira de contenção para novas interpretações. Warat, que se tornou entre nós o autor emblemático do "direito alternativo" ou "direito livre", não vê o direito como produto de que a norma é sua apresentação objetiva, permanecendo ainda submetido à miragem de um direito que consiste num texto legal sobre o qual são lançadas interpretações (construídas pela dogmática, bem entendido). A esse respeito, veja-se Luís Alberto Warat "Sobre la dogmática jurídica" (In: Epistemologia e ensino do direito: o sonho acabou. Florianópolis: Fundação Boiteux, 2004). O mesmo ocorre, de outra forma, com Carlos Santiago Nino (Consideraciones sobre la Dogmática Jurídica. Cidade do México: Universidad Nacional Autônoma de México, 1989, p. 103-112), que, ao descrever as concepções vigentes da dogmática jurídica, ainda se atém ao modelo exegese-norma.

${ }^{118}$ O rigor exige o contexto: "O puritano queria tornar-se um profissional e todos tiveram que segui-lo. Pois quando o ascetismo foi levado para fora dos mosteiros e transferido para a vida profissional, passando a influenciar a moralidade secular, fê-lo contribuindo poderosamente para a formação da moderna ordem econômica e técnica ligada à produção em série através da máquina, que atualmente determina de maneira violenta o estilo de vida de todo indivíduo nascido sob esse sistema, e não mais daqueles diretamente atingidos pela aquisição econômica, e, quem sabe, o determinará até que a última tonelada de combustível tiver sido gasta. De acordo com a opinião de Baxter, preocupações pelos bens materiais somente poderiam vestir os ombros do santo 'como um tênue manto, do qual a toda hora se pudesse despir'. O destino iria fazer com que o manto se transformasse numa prisão de ferro [stahlhartes Gehäuse]." Max Weber, A Ética Protestante e o Espírito do Capitalismo. (São Paulo: Pioneira, 1994), p. 131.

119 "Autorreferencialidade" e não "intertextualidade". Um exame da dogmática mostra não só que ela se alimenta de si própria, como também que os autores freqüentemente referem-se a si mesmos. Não se trata de referências a outros textos doutrinários, o que seria esperado e razoável, como mecanismo de apoio argumentativo ("científico", como ainda hoje se fala no direito), seja porque a tese é de outro autor, seja porque o que se pretende é contrapor-se a outrem. Não: se a dogmática, conforme a função que lhe foi atribuída pela teoria do direito mais difundida, deve sistematizar e interpretar o direito, então estamos diante do fenômeno paradoxal de um gênero literário que fala muito pouco do texto legal (por vezes deparamo-nos com artigos que não fazem menção a nenhum!) e muito de si mesmo. Circulando dentro de uma tubulação que os torna cada vez mais imunes ao exterior, tais textos revelam que desempenham um papel inteiramente diverso do que a família positivista propunha que devessem desempenhar. Cabe-lhes a construção dessa representação que forma o modo de ver social daqueles envolvidos com o direito. E é por isso que ainda se diz, repetindo o século XIX, que não à lei, mas à dogmática, cabe oferecer definições (o que sempre foi falso). Entende-se muito bem por quê. 
O desenho institucional que distingue o locus de produção de ambos importa menos do que suas características comuns. Como lhes cabe, em última instância, "fundamentar" uma decisão de poder, essa decisão só ganhará legitimidade para quem as produz e para quem são destinadas se encontrarem um apoio numa representação social que é por eles proposta im-

plicitamente. É porque a sociedade é e deve ser de certa maneira, porque os indivíduos são e devem comportar-se de certa forma, porque tudo deve ser de um certo modo, que a decisão termina por ser aquela. O recurso à doutrina, mas principalmente a outras decisões, preferencialmente de hierarquia superior, reforça a representação, que se reitera de decisão em decisão. O texto legal, mais uma vez, se torna apenas aforismático, inserido na retórica do poder como soberania emanada de um só. Se há recurso a "princípios", estes aparecem apenas para reforçar os traços da mesma imagem que está sendo permanentemente reproduzida. A retórica da "aplicação da lei ao caso concreto", que não existe magistrado que não empregue (eu inclusive), exibe a imagem do juiz como matemático que deduz e artífice que impõe uma forma a uma matéria. É a principal narrativa de autolegitimação judicial. Qualquer um que tenha como colegas magistrados ou que tenha intensa experiência na comunidade jurídica (e uma certa reflexão crítica, claro), sabe bem que ela não poderia estar mais distante da realidade. Resta saber de onde provém a força dessa ilusão renitente.

\section{Diferenças, tensões e o som surdo do silêncio}

Uma das características desse conjunto de imagens-narrativas que compõem a representação social do Direito Privado condutora da comunidade jurídica interpretativa é não tanto a positividade, mas a negatividade. A impressão de quatro camadas numa figura única, distorcida e desalinhada, é capaz de desempenhar sua função antes pelo que lhe falta, pelo que não está ali, do que pelo que se apresenta. É pelos silêncios que estão presentes nesse retrato que ela é capaz de guiar a produção do direito e a decisão. Aparentemente não deveria ser assim, especialmente quando se está diante da decisão judicial. Aristóteles havia alertado para o fato de que normas são incapazes de descrever a totalidade dos casos possíveis e, se foram imaginadas para alguns, sua aplicação a todos os outros pode conduzir a paradoxos que consistem em contradizer o próprio "critério de justiça” (para ele, comutativa) em que se apóiam. Daí a necessidade de uma outra virtude especial, a epikeia, que amoldaria, como uma régua dúctil, a regra ao caso, afastando-a quando sua aplicação fosse "injusta", ou criando alguma para o caso concreto, quando nenhuma fosse aplicável. A dialética da norma geral e abstrata e do fato concreto cuja radical singularidade a nega só 
poderia ser solucionado por um sistema de competências psicológicas que, em última instância, remontavam à prudência, com todas suas outras virtudes auxiliares.

Assim, à primeira vista, a omissão, silêncios, vazios são tudo que não poderia haver na imagem que deve conduzir o direito como prática decisória. No entanto, o fato é que não só a superposição das diferentes figuras opostas num todo ao preço de perda da nitidez, mas, sobretudo, seus vazios o que permite que sirva de guia. Antes de prosseguirmos com a resposta, um exercício clássico de desconstrução, um pouquinho à maneira de Derrida, não será inútil.

Vimos que as imagens superpostas que examinamos acima emergem de um sistema de oposições. O homem autônomo e, assim, eticamente responsável, contrasta com o voluntarioso e irresponsável. O homem justo e honesto opõe-se ao aproveitador depravado. $\mathrm{O}$ indivíduo racional maximizador opõe-se ao indolente e ineficiente. A proteção à desigualdade contrapõe-se à opressão econômica. Esse sistema de diferenças poderia prosseguir mais adiante, recolhendo o sistema de diferenças que encontramos no próprio Direito Privado: a pessoa e a coisa, a pessoa capaz e a incapaz, o credor e o devedor, o proprietário e o possuidor, o locador e o locatário, o comprador e o vendedor, o acionista e o administrador, todas elas tendo como característica não só a oposição conceitual, mas sobretudo um desnível valorativo implícito de alguma espécie (o devedor é o que não paga, o que descumprirá o contrato, o que causou em algum momento o dano; o incapaz não tem vontade própria, devendo ser representado ou assistido; a coisa não tem direitos, sujeitando-se inteiramente a seu proprietário).

Esse sistema de diferenças valorativas permite preencher as lacunas e explica também como a imagem final resultante se vê forçada a esbater os conteúdos e porque podem apresentar-se em textos ou narrativas jurídicas umas ao lado das outras. Elas afastam o risco de colapso da representação diante de casos inéditos, o que ocorreria se ela fosse obrigada a multiplicar suas determinações indefinidamente. Se a representação tivesse de tornar-se cada vez mais detalhada, cada vez mais o rosto ameaçador, com suas rugas, vincos e pregas, da pintura de Velásquez, a contradição entre a realidade social e a representação levaria a sua implosão. Ela não só perderia a operacionalidade jurídica como perderia a própria capacidade de sustentar a "legitimidade" da decisão. Um sistema de diferenças superpostas suficientemente aberto, mas no qual as figuras ainda são reconhecíveis, é condição da própria funcionalidade e sobrevivência dessa representação.

Mas é também condição de sua existência que omita. As quatro figuras que com- 
põem o quadro são, é preciso dizer agora claramente, ainda as figuras do indivíduo abstrato. Suas quatro caricaturas, que podem conviver num desenho único, projetam sobre a realidade social a ontologia do indivíduo burguês da modernidade. Em qualquer uma de suas quatro formas, é sempre a face quadriproteiforme do indivíduo despido de determinações sociais concretas que vemos ressurgir. As diversas narrativas que se somam à determinação dessas figuras, na sua repetitiva monotonia, prestam-se à ocultação, mas não através, como já se pensou, da interposição de algo com seu objeto. Ela ocorre muito mais pela $o$ missão que pela intromissão. Sua força decorre do fato de que não constituem uma mentira, mas uma meia verdade.

A investigação da fonte mimética das representações textuais não tem ficado ao encargo da filosofia do direito, et pour cause. Apenas no estudos do movimento denominado Law and Literature o tema é tratado, porém muito à parte e secundariamente, como tópico final ou suplementar, após o exame da relação entre literatura e liberdade de expressão, da obra literária como ilustração de conceitos jurídicos (especialmente históricos) ou a literatura como artifício pedagógico para o ensino do direito. Ele costuma distinguir dois focos de interesse, o Law in Literature e o Law as Literature (direito na literatura e direito como literatura). O motivo mais profundo talvez resida não só na centralidade da interminável discussão de todos com a família positivista, que ainda hoje, em sua centésima metamorfose, polariza sem fuga possível a atenção para si e conduz a agenda do debate, como se costuma dizer. As razões são, talvez, duas, e interconectadas: a miragem da norma jurídica como constituindo a partícula subatômica fundamental do direito, sobre a qual, de uma maneira ou de outra, as análises verdadeiramente sérias deveriam debruçar-se; e as dificuldades metodológicas em extrair da trama textual resultante da prática jurídica a representação social que a produz e conduz. Essa tarefa conduz necessariamente a uma crítica ideológica do direito pelo ângulo não do produto, mas da atividade de produção, o que, sob certas condições, só pode levar a contribuir para sua instabilidade. A abertura para visitação do pátio onde se dá o processo de produção da fábrica normativa nunca será inteiramente inofensivo. $^{120}$

\footnotetext{
${ }^{120}$ Há ainda uma última razão. É que a literatura, diferentemente dos produtos da prática jurídica, de um lado organiza-se num sistema de obras mais frouxo, menos coeso; e, de outro, é um produto cultural que não se insere numa prática direta de poder. A prática jurídica sustenta-se, como vimos, na existência de uma comunidade interpretativa capaz de atribuir sentido aos textos legais e operar com o direito a partir de uma representação social. Assim, ela exige a formação de um sistema muito mais denso do que o literário, que só ganha autonomia quando há referencialidade das obras entre si e especialmente no curso
} 
Não é aqui o lugar para narrar a história da teoria literária que levou a sério o conceito de ideologia como representação da realidade social e menos ainda apresentar um panorama, provavelmente bastante inútil, dos vários autores que propuseram que se examinasse o direito a partir das ferramentas contidas em seu almoxarifado. A questão que nos interessa, pois o que era para ser um atalho já está ficando uma trilha excessivamente longa, é saber como a representação social que preside a produção textual do direito se relaciona com a vida social concreta. Deparamo-nos com o indivíduo abstrato burguês da modernidade e suas metamorforses, manifestando-se em seu conjunto de narrativas. A exemplo de uma obra literária, como a massa textual jurídica constrói a realidade a que pretende, de alguma forma, se referir?

Vimos antecipando insistentemente acima que uma das características daquela representação social é a omissão ou a ausência. Pois é essa a maneira como linguagem da obra literária, segundo Pierre Macherey, constrói seu mundo e se relaciona com a vida social:

O que é importante numa obra é o que ela não diz. Isso não é uma nota abreviada: o que ela se recusa a dizer; o que já seria interessante: e sobre isso poderíamos erguer um método, tendo como tarefa medir os silêncios, confessados ou não. Mas antes: o que é importante é o que ela não pode dizer, porque é aí que se desempenha a elaboração de uma fala, numa espécie de caminhada para o silêncio. [...] Os empreendimentos que a interrogação permite descobrir são: "esconder", "desviar o olhar" e, mais adiante, "dissimular". Há evidentemente, ligando todas essas operações, uma ordem: esconder é não tornar visível; desviar o olhar, mostrar sem deixar ver, impedir de ver o que é ao mesmo tempo mostrado; ou ainda, num outro sentido: ver sem deixar ver; o que também exprime corretamente a imagem da dissimulação: agir com dissimulação é sempre agir. Tudo se passa como se houvesse um deslocamento do acento: a obra se revela a si mesma e aos outros em dois planos diferentes: ela torna visível e ela torna invisível. Não somente porque para mostrar uma coisa é preciso não mostrar outra. Mas porque: da própria coisa que se mostra, o olhar dela se desvia. É a superposição do falar e do dizer: se o autor nem sempre diz aquilo de que fala, ele não necessariamente fala do que diz. [...] Na borda do texto, acabamos sempre por reencontrar, momentaneamente oculta, mas eloqüente por essa ausência mesma, a linguagem da ideologia. O caráter de paródia da obra literária despoja-a de sua espontaneidade aparente e faz dela uma obra segunda. Nela, elementos diferentes, através da diversidade dos modos de sua presença, se contestam mais do que se completam: a "vida" que carrega consigo a fala cotidiana, cujo eco se reencontra na obra literária, é remetida a sua irrealidade (que é acompanhada da produção de um efeito de realidade), enquanto que a obra acabada (já que nada pode lhe ser acrescentado) mostra na ideologia o inacabamento. A literatura é a mitologia de seus próprios mitos: ela não precisa de modo nenhum de um adivinho que venha descobrir seus segredos. ${ }^{121}$

do tempo. A história da filosofia, que talvez constitua um sistema um pouco mais denso que o da literatura em virtude de sua recente institucionalização universitária, não parece ser diferente.

${ }^{121}$ Pierre Macherey, Pour une théorie de la production littéraire, Paris, François Maspero, 1971, p. 135-137. 
Para os que não estão acostumados com a tradição francesa, o trecho poderá parecer obscuro. Na verdade, Macherey apenas chama atenção para o fato de que a ideologia opera na obra literária através do que ele denomina o "não-dito", ou seja, por meio daquilo que ela deixa de expressar, lançando-o para um segundo plano. Um modo de produção, uma estrutura de relações sociais, a experiência da opressão do trabalho abstrato, as diferenças reais entre indivíduos, grupos e classes sociais, permanecem todos como um fundo nãotematizado da obra literária, sem o qual ela não existe, mas, ao mesmo tempo, que ela suprime. Como que mostrando sem mostrar, aludindo em silêncio, mantendo num subentendido que tem de ser recalcado, a obra literária importa para dentro de si a ideologia cotidiana. É por isso que há dentro dela uma "obra segunda": nesse sistema de silêncios, de "não-ditos", reaparece, "momentaneamente oculta, mas eloqüente por essa ausência mesma" - que não poderia ser tematizada, sob pena de a obra literária perder seu efeito mimético - a "linguagem da ideologia". É por isso que ela é uma paródia e um produto de segundo grau. É assim que ela oculta a ideologia ao mesmo tempo que é seu produto acabado: o texto literário é o análogo do sonho, tal como a censura da ideologia é análoga à censura onírica que Freud nos fez conhecer.

Temos com isso um ganho sobre uma concepção da literatura um tanto mais simples como organização de uma "visão de mundo" de uma classe, a exemplo daquela que Lucien Goldmann desenvolveu, a meio caminho da análise estruturalista e da análise marxista. Uma obra literária, para ele, é uma expressão de uma "visão do mundo", produto não de um indivíduo único, seu autor, mas de um grupo de indivíduos que possuem somente uma consciência relativa dessa própria visão. Alguns indivíduos — os escritores, e, dentre eles, os melhores - dentro desse grupo são capazes de oferecer uma visão coerente dessa visão do mundo, produto de uma visão de mundo transindividual, em que a genialidade do autor e sua personalidade se exprime em sua capacidade de formulá-la de maneira coerente numa obra imaginária. Noutras palavras: "toda criação cultural é ao mesmo tempo um fenômeno individual e social e se insere nas estruturas constituídas pela personalidade do criador e do grupo social em que foram elaboradas as categorias mentais que a estruturam". ${ }^{22}$ O essencial, para ele, é que tanto a literatura quanto a filosofia (e para nós, o direito) são “expressões de uma visão do mundo, e [...] as visões do mundo não são fatos individuais,

${ }^{122}$ Lucien Goldmann, Marxisme et sciences humaines (Paris, Gallimard, 1970), p. 27. 
mas sim fatos sociais". ${ }^{123}$ Para compreender uma obra literária no seu mais amplo sentido, é insuficiente, portanto, assinalar seus traços lingüísticos imanentes: é essencial, ao contrário, revelar as "estruturas mentais transindividuais" compartilhadas por um grupo como "sujeito coletivo", que constituem sua "consciência possível" e que conferem sentido a sua criação numa situação determinada. ${ }^{124}$

Paremos por aqui o passeio e retornemos à filosofia do direito. $\mathrm{O}$ que nos interessa nessa passagem de Pierre Macherey é a descrição de um modo de apresentação da realidade social que opera aludindo ao omitido. Digamos sem medo: uma negação de uma negação, uma negação de segunda ordem. A representação que guia o Direito Privado opera de maneira análoga: pelo silêncio, pelo não-dito, mas por um silêncio, um não-dito qualificados. Não apenas como mero esquecimento, mas como a própria condição da operabilidade dessa representação. É só suprimindo, mas mantendo no horizonte, fora do alcance, mas presente, que a representação social que o produz e conduz pode ainda subsistir sem estilhaçar-se. Nesse sentido, ela é ao mesmo tempo parcial, pois consiste num conjunto de narrativas sem nitidez e abstratas, mas também total, já que a repressão do não-dito supõe sua presença e se projeta sobre a totalidade social. Numa palavra: o individualismo abstrato só tem força mimética na medida em que põe o concreto, ao mesmo tempo que o nega. Ela só é operacional na medida em que, a partir de certo momento, na narrativa, silencia e não prossegue além.

\section{Ritornello al Capo}

É este o momento de um balanço do percurso até agora. As teorias que procuravam encontrar os "fundamentos" últimos (pleonasmo eloqüente) do Direito Privado, devidamente trituradas entre si e livres de seu escolho filosófico (as teorias da justiça nas quais pretendem encontrá-lo), revelaram as imagens que reaparecem recorrentemente no produto

\footnotetext{
${ }^{123}$ Lucien Goldmann, Recherches dialectiques (Paris, Gallimard, 1959), p. 46.

${ }^{124}$ A esse respeito, veja-se Lucien Goldmann, Sciences humaines et philosophie. Suivi de structuralisme génétique et création littéraire (Paris: Presses Universitaires de France, 1952). A Magnus Opus de Lucien Goldmann é Le Dieu Caché: étude sur la vision tragique dans les Pensées de Pascal et dans le théâtre de Racine (Paris: Gallimard, 1955), onde ele, a partir de uma leitura de História e Consciência de Classe, de Lukács, toma por tema a influência da visão trágica do mundo do Jansenismo como grupo social sobre a obra Pascal e Racine, numa época em que se forja o individualismo moderno. Guardemos o belo livro, especialmente a análise do conceito pascaliano de "aposta", que Goldmann conduzirá pela mão a caminhos inimagináveis.
} 
final da atividade jurídica: doutrina, jurisprudência, normas legais. Tais imagens não formavam um quadro unitário. Antes, sobrepunham-se numa representação, forjada no altoforno de uma "comunidade interpretativa" do direito e composta de narrativas em que o personagem central era o indivíduo da modernidade burguesa, com suas transformações recentes: ao mesmo tempo autônomo e honesto, ora emprenhado em proteger seus interesses e economicamente racional, ora posicionado num pólo de desequilíbrio.

A convivência dessas narrativas inconsistentes, fenômeno impossível, era, no entanto, possibilitado por um duplo movimento: a abstração e perda de nitidez das imagens sobrepostas, acompanhado de um silenciamento da realidade social concreta que supostamente descreveriam. O indivíduo do Direito Privado é uma narrativa entrelaçada de várias outras, breves, essencialmente sumárias, e só compossíveis porque é pela sua brevidade que a supressão, a ocultação e a invisibilização podem coexistir. Essas são características da ideologia tal como se (re)apresenta numa obra literária, e, no caso que nos interessa, no Direito Privado como prática de poder que exige uma justificação discursiva para sua legitimação. Daí porque a questão doutrinária tão debatida sobre a natureza e existência do Direito Privado se torna, agora, uma pseudo-questão. Daí porque o problema das lacunas sempre foi um problema teoricamente insolúvel para aqueles que vêem o direito como um conjunto de normas, mas na prática sempre um falso problema, tal como as questões da completude ou consistência do direito "como sistema". Daí porque o direito precisa sempre se manifestar sob a forma da norma positiva, geral, abstrata, neutra, hierarquizada, objetiva e visando "o bem comum"; aparecer como decisão judicial fundamentada racionalmente e que apenas a aplica formalmente; exibir-se numa dogmática que a interpreta como objeto independente e preexistente - precisa apresentar-se dessa forma pelo simples fato de que não pode revelar sua dimensão de ideologia.

Sistema de imagens-narrativas formando uma representação social, ele guia a decisão e a produção normativa, mas se apresenta sob forma de norma. A norma é a exteriorização de uma atividade de poder, e seu fetichismo, a condição necessária da ocultação a todos, seus destinatários e seus produtores, de uma prática (inegavelmente complexa, sem dúvida), mas guiada por uma ideologia de segunda ordem, produzida por uma "comunidade interpretativa" jurídica, que reflete e reforça a própria ideologia social. ${ }^{125}$

\footnotetext{
${ }^{125}$ Hugh Collins recolheu ao menos sete sentidos diferentes da expressão "fetichismo do direito" (Marxism and Law. Oxford: Oxford University Press, 1982, p. 95-100). O fetichismo "do direito" não cor-
} 
Mas é preciso registrar que, nos dias de hoje, a ideologia jurídica surge cada vez mais freqüentemente na forma de discurso direto, violento e sem quaisquer rodeios. "Da ideologia", dizia Adorno, "só resta o conhecimento do que subsiste, um conjunto de modelos de comportamentos adequados às condições vigentes.” E prosseguia:

É pouco verossímil que, hoje em dia, as metafísicas mais eficazes só por casualidade sejam as que se referem à palavra "existência", pretendendo identificar a duplicação do mero existir com as mais elevadas determinações abstratas que é possível obter com esse mesmo sentido de existir. A essa duplicação corresponde, nos resultados, em grande parte, a situação existente na cabeça dos homens. Estes já não sofrem a situação - na qual, ante a possibilidade aberta de felicidade, faz-se sentir, dia após dia, a ameaça da catástrofe irremediável - de considerá-la a expressão de uma idéia, como poderia ser ainda a atitude adotada diante do sistema burguês dos Estados nacionais; hoje, o homem adaptase às condições dadas em nome do realismo. Os indivíduos sentem-se, desde o começo, peças de um jogo e ficam tranqüilos. Mas, como a ideologia já não garante coisa alguma, salvo que as coisas são o que são, até a sua inverdade específica se reduz ao pobre axioma de que não poderiam ser diferentes do que são. Os homens adaptam-se a essa mentira, mas, ao mesmo tempo, enxergam através do seu manto. A celebração do poder e a irresistibilidade do mero existir são as condições que levam ao desencanto. A ideologia já não é mais um envoltório, mas a própria imagem ameaçadora do mundo. Não só pelas suas interligações com a propaganda, mas também pela sua própria configuração, converte-se em terror. Entretanto, precisamente porque a ideologia e a realidade correm uma para outra; porque a realidade dada, à falta de outra ideologia mais convincente, converte-se em ideologia de si mesma, bastaria ao espírito um pequeno esforço para se livrar do manto dessa aparência onipotente, quase sem sacrifício algum. Mas esse esforço parece ser o mais custoso de todos. ${ }^{126}$

Se a ideologia do Direito Privado só podia conformar-se como com os silêncios, o discurso da violência judicial transforma-se hoje no mais puro vazio. As narrativas cedem lugar ao puro grito no texto, gritaria que impõe o poder pela brutalidade crua da força. Aqui já não há mais subentendido, ocultação ou não-dito. Esse vazio embrutecido do discurso da decisão judicial, tão bem conhecido de todos nós, constitui a corrosão final daquela representação social da realidade e abre explicitamente as portas, sempre entreabertas, do fascismo.

responde a nosso conceito de fetichismo "da norma". Como objeto material que se reverte de uma alma, tanto a mercadoria, ao encarnar o valor de troca, quanto o objeto religioso, sobre o qual é projetada a aura mística, são produtos sociais metafísicos. O sentido que atribuo à expressão, portanto, é esse: o fenômeno de um produto social que ganha características que não estão presentes nele e que se esforça por ocultar o processo de sua produção social como tal. A norma jurídica, como idealidade por trás do texto impresso, é um desses exemplos de fetiche, fantasmagoria que se apresenta camuflando seu processo de criação social. Voltaremos à essa caracterização da norma como fetiche no próximo capítulo ao examinarmos como Isaac Balbus encontrou na norma uma homologia estrutural com a forma-mercadoria.

${ }^{126}$ Theodor Adorno e Max Horkheimer, "Ideologia". (In: Temas básicos da sociologia. São Paulo, ed. Cultrix, 1973), p. 205. 


\section{EPÍLOGO:}

\section{Método e ObJeto na Crítica do Direito}

\section{Sobre este epílogo}

Se é correta a descrição do Direito Privado feita anteriormente, ela inevitavelmente nos pede para ir mais além. A primeira conclusão é que o direito deixa de ser visto a partir dos textos e da fantasmagoria que eles produzem — o fetichismo da norma -, mas se torna uma prática de poder, portanto uma atividade coordenada por uma representação social, nascida na comunidade de intérpretes do direito e reproduzindo a ideologia da própria sociedade em segunda ordem. Atividade, representação social, imagens, narrativas, comunidade interpretativa, ideologia do individualismo da modernidade burguesa, produtos textuais e modo de manifestação substituíram, nas páginas anteriores, os tradicionais conceitos de norma, sistema, hierarquia, coerência, completude, sentido e critérios de identificação do direito.

As páginas seguintes desta tese de doutoramento constituem um texto confessadamente exploratório dessas noções. Não pretende, não poderia (as regras deste gênero acadêmico-literário já foram excessivamente violadas nas páginas anteriores), em poucas páginas, apresentar uma teoria geral do direito ou ousar uma resposta às questões clássicas da filosofia do direito. Não se procure mais do que o rascunho do mapa de algumas trilhas possíveis diante das questões clássicas que compõem o estoque de problemas da filosofia do direito. 


\section{O fetichismo da norma}

a) Metamorfoses do positivismo

Uma das teses que caracterizam a chamada "família positivista" é, para empregarmos a expressão de Dworkin, a das "fontes sociais do direito". Como sabemos, a família não é uniforme e entre avós, tios, sobrinhos e primos a semelhança pode ser muito tênue. Como quer que seja, ao menos nisso estão de acordo todos aqueles que afirmam pertencer a essa família. Segundo essa tese comum, o direito é um sistema — o sentido dessa palavra variará conforme o autor - cujo componente fundamental é uma regra "jurídica”. No mínimo, o conjunto de normas constitui uma rede articulada pelo critério de hierarquia das fontes normativas (vale mais uma norma prevista na Constituição do que uma prevista no Código Civil e menos ainda aquela que as partes fizeram inserir num contrato: a primeira prepondera sobre as demais e assim sucessivamente) que se basta. Não é necessário, para esclarecer a natureza do direito, nada mais além do conceito de "regra", num sentido vagamente sociológico da palavra. É assim que, nas palavras de Dworkin,

O direito de uma comunidade é um conjunto de regras especiais utilizado direta ou indiretamente pela comunidade com o propósito de determinar qual comportamento será punido ou coagido pelo poder público. ${ }^{127}$

Basta, portanto, o pedigree da regra, como se ela fosse um cão de raça ou um vira-lata, para poder identificá-la como pertencendo ou não ao direito. A verificação de se uma norma, como um cachorro, possui ou não esse pedigree seria de responsabilidade de uma regra social, a que, desde Hart, se costuma chamar de "regra de reconhecimento". Essa regra permite "reconhecer" - identificar — se uma norma tem ou não cidadania jurídica. Essa "regra de reconhecimento" tem uma natureza exclusivamente social. É uma norma complexa, que envolve elementos vários como a competência da autoridade que a editou, seu modo de produção (maioria simples ou maioria qualificada? houve interstício de cinco dias?) e até certo ponto seu conteúdo (está em contradição material, isto é, de sentido, substancial, com outra norma de hierarquia superior?). O essencial, porém, é que é ela quem define o que é e o que não é pertencente à cidadela do direito: ela é o porteiro do direito.

Assim, por exemplo, uma norma como o Código de Processo Civil de 2015 é uma

${ }^{127}$ Ronald Dworkin. Levando os direitos a sério. (São Paulo: Martins Fontes, 2002), p. 28-29. 
regra que pertence ao direito porque, entre outras coisas: 1) foi elaborada por órgãos legislativos previstos em outra norma hierarquicamente superior (a Constituição); 2) sua redação obedeceu ao previsto em outras normas (os Regimentos das duas Casas Legislativas: Câmara dos Deputados e Senado); 3) sua aprovação se deu em conformidade a outras normas igualmente jurídicas (novamente: Regimento e Constituição); 4) por fim, sujeitou-se a sanção (e vetos) presidenciais, promulgação e publicação, todos atos igualmente previstos em outras normas. Assim, a determinação da natureza do direito dependeria, para a família positivista, exclusivamente do próprio direito. O direito constitui-se a si mesmo, cerca seus próprios limites de dentro e prescinde de qualquer critério externo a ele próprio para definir-se. Em particular, é irrelevante, a princípio ao menos, ${ }^{128}$ examinar o conteúdo de uma norma para avaliar se ela pertence ou não ao campo do direito. São irrelevantes considerações morais sobre elas, sobre sua adequação a qualquer padrão externo de justiça ou mesmo sua eficiência. Direito é o que o direito diz que é direito. ${ }^{129}$

Dessa primeira característica - que, percebamos, é conseqüência do pressuposto fundamental da família positivista: a célula fundamental do direito é a "norma", ou "regra", se se preferir (o que estamos denominando de "centralidade da norma") — seguemse, ainda de acordo com Dworkin, necessariamente duas outras: a "tese da obrigação" e a “tese da discricionariedade". Ambas são apenas, a bem dizer, corolários da "tese" anterior. A primeira afirma que se o direito é um conjunto de normas e nada mais além disso, então só há obrigações — aqui no sentido de "deveres jurídicos" — onde houver regras válidas que as instituírem. Contra o jusnaturalismo, o positivismo afirmará que ninguém é obriga-

\footnotetext{
${ }^{128}$ Em princípio, pois o quadro é mais complexo, já que na tradição positivista anglo-americana costuma-se distinguir entre os positivistas "exclusivistas" e os "inclusivistas". Numa síntese bastante sumária, os inclusivistas admitiriam a possibilidade de incorporação de critérios morais pelo direito, toda vez que este assim determinasse (como por exemplo o conceito de "improbidade" ou de "decoro", previstos na Constituição Federal ou na Lei de Improbidade Administrativa, ou ainda a "boa-fé" do Código Civil) ou quando o juiz se deparasse com uma lacuna. Trazer para dentro do direito critérios morais que lhe são externos não implicaria, segundo eles, pretender fundar o direito na moral: não seria contrabando, mas importação perfeitamente autorizada. A fidelidade à tese das fontes exclusivamente sociais (ou seja, não-morais) do direito estaria garantida. Já os "exclusivistas" rejeitam a possibilidade de recorrer-se a critérios morais, pois, nesse caso, o direito simplesmente estaria abrindo uma porta de saída para fora dele. Para uma reconstrução do debate no contexto da resposta de Dworkin a ele, veja-se Ronaldo Porto Macedo Junior, Do Xadrez à Cortesia: Dworkin e a Teoria do Direito Contemporânea, (Tese de LivreDocência. Departamento de Filosofia e Teoria Geral do Direito. Faculdade de Direito de São Paulo da USP, 2012), p. 120-130 e Ronaldo Porto Macedo Junior, $O$ direito em desacordo: $O$ debate entre o interpretativismo e o convencionalismo jurídico (Tese de titularidade. Departamento de Filosofia e Teoria Geral do Direito. Faculdade de Direito de São Paulo da USP, 2014), p. 88.

${ }^{129}$ Para o que segue, veja-se Ronaldo Porto Macedo Junior, $O$ direito em desacordo: $O$ debate entre $O$ interpretativismo e o convencionalismo jurídico, op. cit., p. 31.
} 
do a nada que não for jurídico, e como o direito é apenas um conjunto de normas que se define a si próprio, então, ausente uma regra jurídica válida, ausente estará o dever correlato de um determinado comportamento. Por contraposição, quando não houver uma regra clara (porque a regra é obscura, porque há regras contraditórias, ou porque simplesmente não há uma regra), aquele encarregado de "aplicar o direito" poderá fazê-lo "discricionariamente", ou seja, decidir conforme seu alvitre. ${ }^{130}$ Logo, o direito é "convencional”, como afirma Jules Coleman. Não no sentido de que seria análogo a um contrato coletivo, mas no sentido de que, por ser "convencional", não é "natural”, "necessário" (pode ser perfeitamente diferente do que é), nem muito menos "essencial".

A história do positivismo jurídico é a história do empobrecimento. ${ }^{131}$ Nascido nas primeiras décadas do século XIX como produto ideológico das codificações, ele inicialmente pretendia estender ao texto legislado, "positivado" (posto pelo legislador), a inafastabilidade que o jusracionalismo dos séculos anteriores pretendia conferir-lhe. Se o direito natural do racionalismo era um direito racional, organizando-se como um sistema e como padrão de medida da justiça do direito positivo e da decisão judicial, com as codificações, "produto do legislador racional", o jusracionalismo finalmente chega ao poder e ganha as vestes da tinta legal sobre o papel. ${ }^{132}$ Obedecer ao direito positivo (ou seja, positivado) era obedecer a um comando da própria razão que nele se exteriorizava. Se o Código é racional, o dever do juiz é aplicá-lo e não há espaço para criação do direito por outra via (a rigor, nem o legislador criaria o direito, apenas faria com que a razão jurídica se exteriorizasse num texto legislado, portanto escrito). Se o direito natural racionalista ainda se permitia, como padrão de medida da justiça, uma exterioridade diante do direito positivo, textual, o positivismo - que nasce com a "Escola da Exegese" e domina o século XIX francês da edição do Code em 1804 até a Méthode d'interprétation et sources en droit privé positif: essai critique, de François Gény, em que a crise desponta abertamente — pretenderá fundir

\footnotetext{
${ }^{130}$ Ronaldo Porto Macedo Junior, $O$ direito em desacordo: $O$ debate entre o interpretativismo e o convencionalismo jurídico, op. cit, p. 32.

${ }^{131}$ Sobre sua história e seu progressivo esvaziamento, veja-se o meu Transformações da Teoria Geral do Direito: Argumentação e Interpretação do Jusnaturalismo ao Pós-Positivismo (São Paulo: Quartier Latin, 2008).

${ }^{132}$ Veja-se Tércio Sampaio Ferraz Júnior, Função Social da Dogmática Jurídica, op. cit., p. 73-77. A função da dogmática jurídica, que assume a forma de glosa a uma legislação racional que tudo prevê, responde à necessidade de uma "neutralização dos interesses concretos na formação do próprio Direito, neutralização essa já exigida politicamente pela separação dos poderes e pela autonomia do poder judiciário" (p. 75).
} 
ambos num só: texto e direito. ${ }^{133}$ Daí porque o direito é norma, e norma legislada: porque a norma legislada era o próprio sistema de direito racional. ${ }^{134}$

A primeira perda e metamorfose do positivismo ocorre com a crise de seu conteúdo. Não é o caso de nos aprofundarmos nas razões sociais da crise dessa ideologia jurídica ao longo do século XIX. Basta-nos lembrar apenas que se o contrato era descrito como acordo de vontades entre iguais e a propriedade, consistente numa das formas de "exteriorização da personalidade" do indivíduo (que era a propriedade), como se dizia na época, será suficiente o desafio histórico ao conteúdo desses dois institutos para que se passe a desconfiar da racionalidade e da "justiça essencial" do legislador e seus produtos codificados. As traças roem de dentro o Code Napoléon, cujo conteúdo paulatinamente perde a ilusão de imutabilidade "jusracional". Daí que não reste outra alternativa para essa "crise de legitimação" senão ora tentar fazer renascer o contratualismo - o texto legislado é produto da formação de um "consenso social” institucionalizado — , ora simplesmente reconhecer melancolicamente que a obediência ao direito decorria do mero fato de resultar de um ato de poder.

Resta uma estrutura vazia que pode ser preenchida por qualquer conteúdo. O direito passa, agora, a ser uma "pirâmide normativa", uma estrutura, porém despida de uma matéria racional. Se até agora ser direito equivalia a ser um axioma ou teorema de um sistema racional, a partir de então significará pertencer a uma cadeia normativa hierarquizada, que remete a uma primeira norma, um "princípio transcendental”, condição de possibilidade da própria cadeia normativa, que confere validade a todas as demais normas subordinadas, mas que ela própria não pode pertencer à cadeia, sob pena de ter-se de perguntar pela norma anterior que a valida. O raciocínio, sabemos, é o de Kelsen na Teoria Pura do Direito, que simplesmente reproduz a velha solução kantiana para o problema da relação entre o condicionado e o incondicionado na experiência. ${ }^{135}$ Mantém-se, ao preço de seu esvazia-

\footnotetext{
${ }^{133}$ Sobre o fenômeno, veja-se sua descrição, ainda que breve, de Chaïm Perelman em Lógica jurídica: nova retórica (São Paulo: Martins Fontes, 2000), p. 31.

${ }^{134}$ A hipótese do "legislador racional" é devidamente elaborada e desconstruída em Tércio Sampaio Ferraz Júnior, "A hipótese do legislador racional e a noção de justiça" (Cadernos Direito GV, São Paulo, v. 6, 2009). Sobre os pressupostos do "modelo do legislador racional", veja-se ainda Carlos Santiago Nino, Consideraciones sobre la Dogmática Jurídica, op. cit. p. 85-103. Nino menciona como "regras" derivadas do modelo: que o ordenamento jurídico não possui contradições; é operativo; não possui lacunas; é preciso; é dinâmico; e é finalista. Não obstante, registra ele, os diversos ideais pressupostos nesse modelo não estão isentos de contradizer-se.

${ }^{135}$ Para além da "experiência jurídica", que, nesse caso, corresponde às normas positivas, é necessário, para Kelsen, então, pressupor uma norma fundamental transcendental. A esse respeito, veja-se, entre i-
} 
mento, a figura de um sistema, agora edifício composto de habitações vazias dispostas verticalmente umas sobre as outras, "validamente". Todas se encontram sustentadas no alto por um guindaste-treliça que constitui sua "norma hipotética fundamental", necessariamente exterior a ele (o direito, neste momento, ainda não pode ser o Barão de Munchausen e levantar-se a si próprio puxando seus cabelos), e cujo conteúdo pode ser preenchido pelo conteúdo que se preferir. Perde-se o conteúdo e, com ele, a identificação do direito a partir de um padrão de justiça racional. Mas ainda se garante a centralidade da norma, sua disposição numa pirâmide hierárquica, um sistema dotado de unidade (ainda que consistência e completude tenham de ser deixadas para trás) e, finalmente, um critério para identificar o que é e o que não é direito: seu pedigree a partir da norma fundamental, exterior a ele e condição de sua possibilidade.

O Pós-Guerra, e por razões históricas que também não podemos detalhar aqui (dentre as várias, as características do direito durante o período do assim chamado Welfare State), conduziram o positivismo a um empobrecimento que beira a indigência. Restaram-lhe as teses acima mencionadas ou, no máximo do despojamento, apenas a que afirma a "fonte social" exclusiva do direito. Já se foi a pirâmide hierárquica e, com ela, a unidade e a organização num sistema vertical. Resta apenas o direito como um conjunto de regras privilegiadas, que foram selecionadas pela comissão de concurso da "regra de reconhecimento" para compor o seleto círculo jurídico, que identifica e escolhe as novas integrantes. $\mathrm{O}$ direito, assim, é apenas o conjunto de regras selecionadas por uma regra e nada mais. De Hart a Raz, com as variantes inevitáveis, a história do positivismo jurídico caminha no sentido de reduzir o direito exclusivamente à norma, deixando para trás primeiro o conteúdo, e a seguir a sistematicidade hierárquica, a coerência ou a unidade. Restringe-se à norma, sem quaisquer outros ornamentos.

b) Nomocentrismo e ideologia jurídica

O nomocentrismo tinha uma razão histórica para existir. Resta perguntar-nos quais

números outros trabalhos dedicados a esse problema clássico do kelsenianismo, José Antonio Siqueira, Kelsen e o monumento da razão pura: uma análise do conceito de validade jurídica (Dissertação de Mestrado. Departamento de Filosofia e Teoria Geral do Direito. Faculdade de Direito de São Paulo da USP. São Paulo, 2002) e Luís Alberto Warat, "Los pressupuestos kantianos y neokantinos de la teoria pura del derecho" (In: Epistemologia e ensino do direito: o sonho acabou. Florianópolis: Fundação Boiteux, 2004). 
são as razões que fazem com que não desapareça. Antes disso, relembremos alguns de seus efeitos, ou, como preferimos entender aqui, de suas ilusões. A primeira miragem é, como já pudemos indicar acima, a idéia de que exista uma distância entre o direito como linguagem escrita composta de normas produzidas pelo legislador e a interpretação que deve ser lançada sobre tais sinais gráficos. Se, afinal, a norma não se confunde com tais sinais "se todos os exemplares da Constituição fossem queimados, ainda assim não desapareceria a Constituição" —, então é que alguém (o "intérprete") "descobre" seu sentido para além da grafia dos livros. A norma é uma idealidade, um objeto ideal ao qual o sujeito cognoscente do direito tem acesso através do trabalho laborioso da interpretação, um mago que sopra as brumas para encontrá-la finalmente reluzente como um Santo Graal.

Se a maior parte dos positivistas hoje não acredita mais nessa miragem é porque o platonismo deixou de estar em moda e não se encara a norma como se poderia interpretar, talvez, uma idealidade matemática. A norma passa a ser "construção", o que significa que o intérprete, ou uma comunidade interpretativa, fixa o sentido do texto. O direito é assim o produto final de uma interpretação de um texto, limitada por fatores internos e externos ao direito que constrangem seu "grau de liberdade interpretativa". A história e a geografia, por exemplo, impedem que se atribua ao art. 18, parágrafo 1. ${ }^{\circ}$ da Constituição — "Brasília é a Capital Federal" - um sentido no qual "Brasília" designa geograficamente o Rio de Janeiro. O Direito Tributário veda que se interpretem os institutos jurídicos de Direito Privado que nele são mencionados em sentido diverso daqueles contidos em outras normas (art. 109 do Código Tributário Nacional: “Os princípios gerais de direito privado utilizamse para pesquisa da definição, do conteúdo e do alcance de seus institutos, conceitos e formas, mas não para definição dos respectivos efeitos tributários.”). ${ }^{136}$

\footnotetext{
${ }^{136}$ Tércio Sampaio Ferraz Júnior, de uma perspectiva bem diferente daquela apresentada aqui, chama, porém, a atenção para esses mesmos materiais e elementos coercitivos da liberdade interpretativa:

"Vimos anteriormente que a norma decide conflitos, mas, dada a estrutura do discurso que ela instaura, é necessário ver a própria norma, reflexivamente, como um dubium e, pois, como produto de decisão. O discurso da norma exprime assim, em primeiro lugar, um ato de posição 'heterônomo' (segundo Reale), cuja validez só pode ser contestada, em princípio, em virtude de um 'vício de forma'. A norma, nesse sentido, é 'dogma', implicando 'posição' em termos de uma 'interferência decisória do Poder'. Esse 'momento da dogmaticidade', porém, não esgota o discurso da norma. Assim, em segundo lugar, a 'posição' manifesta concomitantemente uma 'opção axiológica' que 'lateja' no bojo da regra jurídica positivada. Em conseqüência, sendo o discurso da norma, em princípio, uma discussão-contra, que está, portanto, a serviço da decisão, ele manifesta uma série de possibilidades que, por razões de controle, têm de ser limitadas: soluções incompatíveis, se, de um lado, são condição da decisão, por outro podem, no momento da decisão, provocar perturbações na decidibilidade. Por isso, o discurso da norma revela por vezes e inevitavelmente uma duplicidade de movimentos,
} 
Se a interpretação é construída, isso significa que o texto legal não possui um significado prévio, anterior à atividade de construção. Em tese, não houvesse os fatores limitantes, o texto admitiria qualquer significado. Mas assumamos não a posição do intérprete, mas de um terceiro que observa a cena de fora. O intérprete está sentado na frente de sua escrivaninha de trabalho, cercado de livros por todos os lados. Ele se vê como descobrindo o direito ao ler os textos que, para ele, ora são a própria norma, ora são a escada para alcançá-la. $\mathrm{O}$ observador exterior à cena assiste a um drama diferente. $\mathrm{O}$ intérprete não tem diante de si nenhum texto à espera de contar-lhe sobre as normas. Antes, ao deparar-se com um problema ao qual pretende conferir a roupagem discursiva de uma solução jurídi$c a$, seu movimento mental consistirá em, a partir do conjunto de conteúdos subjetivos à sua disposição (narrativas, imagens, estratégias, horizontes de significados, posições no campo social acadêmico e jurídico, preconceitos e pré-julgamentos políticos e sociais, etc.), compor um quadro textual cujo produto final é uma decisão, uma interpretação, ou até mesmo o projeto de uma norma.

Visto em terceira pessoa, portanto, o intérprete nada interpreta, mas constrói tendo a representação social que o guia como norte. O nomocentrismo nasce da ilusão de identificar o texto, seja ele um dispositivo legal ou uma decisão judicial, seja um parecer ou um artigo doutrinário, que são produtos ou modos de manifestação do direito, com o próprio direito como práxis. Reduzido o direito ao texto, ele fatalmente será absorvido pela norma: o direito é a norma, como elemento fundamental de um sistema no sentido mais fraco da palavra. Sendo regra de conduta identificada por uma outra regra institucionalmente legítima (a "regra de reconhecimento" de Hart), o direito nada mais pode ser senão o estoque de todas as regras por ela reconhecidas como tal. É, portanto, porque o direito é tomado pelo seu modo de aparição que a norma passa a arrogar-se a centralidade do Filho de Deus, que é e fala em nome do Pai. E mesmo o positivismo mais refinado de Joseph Raz será o-

que pendem entre um processo de 'diferenciação' e uma certa manutenção da 'difusividade'. Assim, se de um lado, como observa Boas, 'a história da terminologia legal tem-se movido na direção de distinções sutis', de outro também assiste razão a Eckhoff, quando lembra que concepções de justiça e de utilidade social são bem apropriadas para ser amoldadas em harmonia uma com a outra, por causa de seu sentido vago e da incerteza ligada a algumas de suas premissas, tendo em vista a necessidade de harmonia nas crenças, atitudes e ações. Nesse sentido, entende-se um certo paradoxo notado por Schein no próprio estilo do jurista, o qual, em princípio, pressupõe que todas as disposições legais se harmonizem umas com as outras, o que constitui, para ele, uma prasumptio júris, isto é, ele se convence, de quando em vez, do contrário, mas não crê, em princípio, que isso seja assim e procura, com grande empenho, conciliar disposições legais concompatíveis". (Direito, Retórica e Comunicação. São Paulo, Saraiva, 1997, p. 108-109). 
brigado a manter no horizonte dessa concepção nomocêntrica do direito uma concepção da soberania e do Estado como aquele que, afinal, é quem estabelece os critérios constantes da regra de reconhecimento. Mesmo aqui, gerações após, reconhecemos o traço de família: a representação monárquica do poder que põe a norma a que todos devem obedecer.

A miragem nomocêntrica alimenta sua ilusão também de outra fonte, talvez a mais importante. O direito aparece sob a forma de um texto, que materializa a norma, a decisão ou a doutrina. Sua forma de aparição obedece a uma função social: aparecendo como norma, traz consigo os predicados ofuscantes da universalidade, igualdade e, particularmente, neutralidade axiológica. A decisão judicial poderá aparecer agora como uma aplicação pelo juiz ao caso concreto de uma norma exterior que não é dele, de que não é responsável, mas que lhe foi dada e limita sua liberdade: Iaveh ditando a Moisés os mandamentos. O parecer, o texto doutrinário aparecem como dotados de uma objetividade emanada por um direito, composto de normas, que não se confunde com aqueles e ao qual eles se curvam, como diante de um poder inevitável. A forma de aparição de tais formas textuais, portanto, é essencial para sua ocultação ideológica como prática de poder. Chamemos um autor acima de qualquer suspeita para esclarecer esse mecanismo com maior precisão:

Tanto a teoria dogmática da aplicação do direito quanto a teoria da argumentação jurídica mostram um quadro em que a decisão aparece como um sistema de procedimentos regulados em que cada agente age de certo modo, porque os demais agentes estão seguros de poder esperar dele certo comportamento. Não se trata de regularidades lógicoformais, mas, por assim dizer, ideológicas. O discurso dogmático sobre a decisão não é só um discurso informativo sobre como a decisão deve ocorrer, mas também um discurso persuasivo sobre como se faz para que a decisão seja acreditada pelos destinatários. Visa despertar uma atitude de crença. Intenta motivar condutas, embora não se confunda com a eficácia das próprias normas. [...] $\mathrm{O}$ discurso decisório, nesses termos, é avaliativo e ideológico. [...] Responde pela constituição de premissas e postulados da argumentação (princípio da irretroatividade das leis, a exigência de que a mesma ratio legis deve permitir tratamento jurídico igual a casos semelhantes). Por todas essas razões, pode-se dizer, por fim, que a dogmática da decisão constrói um sistema conceitual que capta a decisão como um exercício controlado do poder, como se as relações sociais de poder estivessem domesticadas. Sublima-se a força e, com isso, diminui-se a carga emocional da presença da violência do direito. ${ }^{137}$

Se a forma textual do direito é seu modo de aparecer necessário, como produto final, para com isso esconder-se como ato de poder e violência, sublimando-se a força e, com isso, diminuindo-se "a carga emocional da presença da violência do direito", então sua forma de manifestação é inseparável de seu conteúdo. Melhor ainda: é antes a forma, em vez de seu

${ }^{137}$ Tércio Sampaio Ferraz Júnior, Introdução ao Estudo do Direito: Técnica, Decisão, Dominação. (4. ${ }^{\text {a }}$ 
conteúdo, o que lhe confere a capacidade de produzir a impressão de objetividade, impessoalidade, neutralidade e isonomia naqueles que são por ele afetados — "persuasividade". É porque ele aparece sob a forma de um texto escrito que a doutrina - a dogmática jurídica, no rigor terminológico - pode ter a impressão tanto de que há algo para ser interpretado, quanto que nada há a interpretar, dada a distância de sua exteriorização como algo dotado de objetividade. É, mais uma vez, por isso que a decisão pode apresentar-se como a aplicação anônima de uma idealidade metafísica que toca a terra. É, finalmente, porque ele aparece como um objeto normativo que o próprio processo de sua produção pode recuar para um segundo plano inteiramente obscuro e nebuloso, o segundo plano no qual sua imagem-narrativa não aparece como criação, mas como realidade independente.

Se é assim, é preciso recusar desde o início não só o pressuposto nomocêntrico do positivismo, mas tudo mais que o acompanha. E em primeiro lugar a própria idéia de sistema jurídico como conjunto das normas que nele ingressam apenas com autorização expressa da "regra de reconhecimento". Se o texto legal é apenas a forma de apresentação do direito, já não faz mais sentido sustentar a existência de fronteiras entre o que lhe pertence e o que não lhe pertence. O problema da fronteira do direito diante da moral, que se colocava, como vimos, para o positivismo de maneira especialmente espinhosa - afinal, o que distingue a moral, que também é supostamente um conjunto de normas, do direito que caracteriza como tal? - , é parasitário desse conjunto de pressupostos. Na prática, a questão sempre soou artificial, não tanto porque o direito tivesse de sujeitar-se em algum momento à moral para enfrentar o direito injusto (o Holocausto recolocou esse falso problema para o positivismo como nenhuma outra de suas crises anteriores o havia feito), mas porque as narrativas que tecem as imagens de que é composto simplesmente tornam sem sentido a distinção. É assim que se mostra artificial a controvérsia entre "exclusivistas" e "inclusivistas": "se o direito autorizar, então pode-se permitir à moral que ingresse, sob condições e muita vigilância, na cidadela jurídica". Mas se as manifestações do direito são veiculações de uma certa imagem da vida social, não há mais porque indagar se a moral, humilde "conjunto de normas não estatais", poderia ou não adentrar à mansão do direito. E isso não porque o direito encontre, de alguma maneira, seu "fundamento" na moral: apenas porque ambas são guiadas por representações sociais — "avaliativas e ideológicas", numa palavra, ideológicas.

Edição. São Paulo: Atlas, 2003) p. 344-347. 
Com isso também passam a não mais fazer sentido as dificuldades que se colocavam para o normativismo - passemos a empregar esse termo, mais preciso, a partir de agora — relativas à unidade do sistema, sua completude ou consistência. O normativismo via o sistema jurídico como uma estrutura oca que podia ser preenchida por qualquer conteúdo, bastando que alguma regra assegurasse sua unidade (para Kelsen, a hierarquia normativa alinhavava, com o fio da validade, todas as normas num grande tecido) para que ele pudesse ser erguido. Mas nada impedia que a regra admitisse a inconsistência (normas ou decisões incompatíveis entre si, igualmente pertencentes ao sistema) ou a incompletude (lacunas, ou seja, vácuos normativos em que casos não são cobertos por nenhuma norma). A primeira e mais antiga solução para o problema surgiu tanto com a introdução de novas normas que solucionariam as antinomias jurídicas (se a norma é posterior, afasta a anterior; se é específica, prepondera sobre uma genérica; se é superior, prevalece sobre a inferior, etc.), como através do apelo ao velho método aristotélico da analogia (casos semelhantes, soluções idênticas). Claro que as soluções foram inteiramente insatisfatórias, não só porque nem todos os casos de antinomias podiam ser solucionados através dessas regras (as chamadas "antinomias de segunda ordem") e porque se constatou ser possível construir decisões contraditórias “dentro da moldura da norma", como percebeu Kelsen, mas também porque a analogia era um método com quem a filosofia moderna unanimemente se tinha inimizado (a analogia jurídica pode ser construída nos dois sentidos, renascendo o problema de saber qual o critério para a escolha da característica relevante a ser tomada). ${ }^{138}$ Sua unidade num sistema, na verdade, decorre da força da representação ideológica que lhe serve de guia.

c) Gênese e persistência de uma ilusão: forma-mercadoria e forma jurídica

O normativismo é uma daquelas muitas ilusões da vida de que temos de nos esforçar constantemente para não recairmos na sua sedução. Uma leitura a partir da psicanálise não seria desparatada. Como o prestidigitador ou o batedor de carteiras, seu truque consiste em

\footnotetext{
${ }^{138}$ Um resumo das insuficiências dos critérios de solução de antinomias encontra-se em Norberto Bobbio, Teoria do ordenamento jurídico (6. ${ }^{\mathrm{a}}$ ed.. Brasília: Editora Universidade de Brasília, 1995), p. 91114. Ainda sobre o chamado "problema da integração do direito" (ou seja, torná-lo íntegro, inteiro, portanto sem lacunas), veja-se o estoque de dificuldades trazidas pelo recurso à analogia ainda em Bobbio, Teoria do ordenamento jurídico, op. cit., p. 150-160 e, do mesmo autor, O Positivismo Jurídico: lições de filosofia do direito (São Paulo: Ícone, 1995), p. 207-210 e 214-219.
} 
desviar nossa atenção, como o não-dito das imagens ideológicas de que falava Macherey, cujos gritos se fazem presentes no desconforto de seu silêncio. Porém, há algo mais: ilusão necessária, no sentido filosófico que desde Kant nos atormenta. Ele é a própria forma dessa ideologia, seu modo de ocultação da ideologia jurídica enquanto tal. Se, como Lukács sugeria, é a forma romance, e não seu conteúdo, onde reconhecemos mais nitidamente a força da sedução ideológica, podemos dizer, numa analogia não de todo despropositada, que é sobretudo a forma normativa (e seu correlato, o sistema), modo de manifestação do direito, que confere força à representação ideológica que ele veicula. Fantasmagoria ou fetichismo da norma, se se preferir.

O nomocentrismo, portanto, responde a uma função. Mas qual é exatamente o mecanismo pelo qual ele opera? Noutras palavras: como funciona precisamente o "fetichismo da norma"? Vimos que ela se apresenta como dotada de uma autonomia, de uma vida própria, como um produto da alienação (leia-se Entäußerung, como nos Grundrisse), a exemplo de outros muitos, e é através dela que, enquanto forma, é possível ocultar tanto seu processo de autonomização quanto sua natureza de instrumento ideológico. O levantamento dessa dupla operação foi exposto num artigo seminal de Isaac D. Balbus, de 1977, "Commodity Form and Legal Form: An Essay on The 'Relative Autonomy' of the Law”, cujo núcleo argumentativo estou certo de que vale a pena reproduzir aqui. ${ }^{139}$

A análise de Balbus parte de uma crítica ao marxismo, digamos, "ortodoxo", que concebe o direito de uma perspectiva instrumental e reducionista, como expressão de interesses dos atores sociais, no que, surpreendentemente, não se distancia por um certo ângulo da visão liberal do direito. ${ }^{140}$ À concepção instrumental do direito opor-se-ia, supostamen-

\footnotetext{
${ }^{139}$ Isaac D. Balbus, "Commodity Form and Legal Form: An Essay on The 'Relative Autonomy' of the Law" (Law and Society Review, 11, 1977), p. 571-588. O artigo é uma resposta a uma resenha de David Trubek ("Complexity and Contradiction in the Legal Order: Balbus and the Challenge of Critical Social Thought about Law", Law and Society Review, 11, 1977) do livro de Balbus The Dialectics of Legal Repression (Nova York: Russell Sage Foundation, 1973).

${ }^{140}$ Cabe lembrar que o marxismo sempre tendeu a enxergar o Estado como estrutura que se superpunha à infraestrutura das relações sociais de produção, numa leitura apressada e esquemática do prefácio da Contribuição à Crítica da Economia Política de Marx. Se é verdade que os clássicos - Lênin em $O$ Estado e a Revolução, Rosa Luxemburgo em "Reforma ou Revolução?", Gramsci na Nota sobre Maquiavel, Trotski em A Revolução Traída - elaboraram uma concepção de Estado pouquíssimo esquemática e ingênua (cabe o diagnóstico dessa dialética por Gérard Lebrun: "sabiam do que falavam porque o faziam"), uma parte do marxismo do Pós-Guerra dito "ocidental" voltou à carga na teoria do Estado como superestrutura, tornando-se vulnerável aos ataques das melhores concepções liberais ou pósmodernas da natureza do poder (Hannah Arendt, Michel Foucault). Talvez o melhor exemplo seja a polêmica do althusseriano Nikos Poulantzas com o anglomarxista Ralph Milliband, em que ambos partilham os mesmos pressupostos do Estado como "estrutura de poder" relativamente independente.
} 
te, o formalismo, que concebe o direito como uma ordem autocontida e autônoma relativamente às vontades e interesses sociais, funcionando e desenvolvendo-se conforme sua própria dinâmica. A oposição, segundo Balbus, é ilusória. O direito possui uma autonomia relativa, princípios de organização que lhe são próprios, uma integridade analítica e traços estruturais que são reproduzidos socialmente - diríamos, produto da "comunidade interpretativa" que o constrói. Ele "não responde diretamente" às demandas dos atores sociais, como uma análise marxista vulgar do direito costuma defender, justapondo, digamos assim, por "acoplamento mecânico", a luta de classes ou a forma de acumulação do capital ao conjunto das normas, sem exibir as mediações necessárias. ${ }^{141} \mathrm{O}$ que não quer dizer que constitua um sistema de relações sociais independente.

Resta saber como ele opera, se é certo que possui apenas uma "autonomia relativa" e não uma independência. Se é certo que o direito não pode ser explicado, como quer o formalismo (e o "interpretivismo"), exclusivamente através de seu desenvolvimento interno, nem se pretende uma resposta tradicional para sua relação com o modo de produção a que corresponde, é preciso agora avançar e desvendar seu segredo de polichinelo. A resposta está na estrutura metafísico-social para a qual Marx apontou em sua análise do "segredo" do fetichismo da mercadoria no capítulo 1 da seção I de $O$ Capital. Já se pode antever o resultado, mas Balbus toma o cuidado rigoroso de não conceber a norma como reflexo ou $e$ feito do fetichismo da mercadoria (leituras apressadas de Paschukanis costumam levar-nos a essa conclusão que, a meu ver, nunca se encontrou nesse autor). O que ocorre é que a mesma estrutura reaparece tanto no objeto-mercadoria quanto na norma - encontramos uma "relação de homologia" entre os dois fenômenos, na expressão de Balbus.

Ora, o processo de extinção da "memória concreta do trabalho" na mercadoria, como se sabe, ocorre mediante uma dupla abstração:

A lógica da forma-mercadoria é, assim, a de um duplo movimento do concreto para o abstrato, uma dupla abstração da forma a partir do conteúdo, uma transmutação dual da qualidade na quantidade. A transformação de mercadorias de objetos desiguais em objetos iguais tem um paralelo, e é mesmo tornada possível por ela, na transformação do trabalho que as produz de desiguais em iguais. Para que mercadorias sejam o que são, tanto objetos desiguais quanto o trabalho desigual que as produziu têm de se tornar o que não são, ou seja, iguais. [...] A forma-mercadoria, em outras palavras, é uma forma econômica que necessariamente funciona independentemente ou autonomamente da vontade dos sujeitos que a põem em movimento. Daí o fetichismo das mercadorias: o

${ }^{141}$ Isaac D. Balbus, “Commodity Form and Legal Form: An Essay on The 'Relative Autonomy' of the Law", p. 572. 
mascaramento da conexão entre as mercadorias e sua origem humana dá lugar à aparência, a inversão ideológica, de que as mercadorias têm poderes humanos vivos. ${ }^{142}$

Já se pode suspeitar, dado o paralelismo entre a forma-mercadoria e a forma jurídica, por que esta nunca é "posta em questão": é a forma a responsável última, o sustentáculo da representação social do direito, já que o faz aparecer como objeto independente dos indivíduos que o produzem. A forma jurídica "cria uma relação fetichizada entre os indivíduos e o direito na qual os indivíduos atribuem subjetividade ao direito e concebem-se a si mesmos como seus objetos ou criações". ${ }^{143}$ Daí que colocar em questão a ordem jurídica e subseqüentemente "deslegitimizá-la" é, diz Balbus, "literalmente “impensável”" (entenda-se: não-pensável).

O fetichismo do direito, então, aparece sob diversas formas. A primeira é o formalismo, ou o que sugeri que se chame de normativismo, ou mesmo nomocentrismo, para quem a independência e autonomia do direito devem ser explicadas a partir de sua "dinâmica interna", "como um sujeito independe, de cuja criatividade depende a sobrevivência da sociedade", dotado de um caráter de indispensabilidade para a própria existência da sociedade ou da "paz e harmonia social". ${ }^{144}$ Sob essa primeira variante do fetichismo jurídico, os indivíduos "afirmam que devem sua existência ao direito, em lugar do contrário, invertendo a relação causal real entre eles próprios e seu produto", o que "impossibilita a possibilidade de avaliar a forma jurídica, já que é impossível avaliar uma entidade que é concebida como uma fonte independente da existência e dos valores de alguém". ${ }^{145}$ Daí porque,

Quando se sustenta que a sociedade é um resultado do direito, em vez de o direito ser resultado de uma espécie particular de sociedade, então o direito, por definição, é não problemático. Ora, colocando de outra forma, a resposta à questão da legitimação — por que os cidadãos apóiam a ordem jurídica? - é, acima de tudo, o fato de que os cidadãos dessa ordem geralmente não colocam nem podem colocar essa questão. ${ }^{146}$

Mas há ainda uma segunda forma como o fetichismo se manifesta, decorrente do próprio processo de abstração e homólogo à abstração concreta da forma-mercadoria:

\footnotetext{
${ }^{142}$ Isaac D. Balbus, “Commodity Form and Legal Form: An Essay on The 'Relative Autonomy' of the Law”, op. cit., p. 574.

${ }^{143}$ Isaac D. Balbus, "Commodity Form and Legal Form: An Essay on The 'Relative Autonomy' of the Law”, op. cit., p. 583.

${ }^{144}$ Isaac D. Balbus, “Commodity Form and Legal Form: An Essay on The 'Relative Autonomy' of the Law", op. cit., p. 574-5.

${ }^{145}$ Isaac D. Balbus, “Commodity Form and Legal Form: An Essay on The 'Relative Autonomy' of the Law", op. cit., p. 574-5.

${ }^{146}$ Isaac D. Balbus, "Commodity Form and Legal Form: An Essay on The 'Relative Autonomy' of the
} 
Tal como o mascaramento da conexão entre as mercadorias e suas origens humanas no valor de uso no trabalho concreto necessariamente dá origem à aparência ou à inversão ideológica de que mercadorias, e especialmente seu equivalente universal, o dinheiro, têm poderes humanos vivos, assim também a abstração e o mascaramento das diferentes necessidades humanas e das origens sociais levadas avante pela forma jurídica produz a ilusão de que o direito - enquanto equivalente político universal - tem uma vida própria. O corolário para relações humanas se tornando abstratas e reificadas (como-coisas) é que as coisas - sejam produtos materiais ou "produtos" jurídicos - se tornam personificadas, isto é, assumem características humanas. O fetichismo da mercadoria e o fetichismo jurídico são, portanto, dois aspectos inseparáveis de uma existência invertida, "de pernas para o ar", sob um modo de produção capitalista no qual seres humanos são primeiro reduzidos a abstrações e, a seguir, dominados por suas próprias criações. ${ }^{147}$

As narrativas que compõem a representação social, na linguagem que vimos empregando, ou seja, seu conteúdo, só são capazes de produzir seu efeito ofuscante, como diria Macherey, na medida em que o direito aparece como forma jurídica. É porque o direito abstrai e mascara as "diferentes necessidades humanas e as origens sociais levadas avante pela forma jurídica" que cria a fantasmagoria de que ele - "equivalente político universal", análogo ao dinheiro como forma do valor enquanto equivalente universal - possui "vida própria". Em síntese:

O sujeito de "direitos iguais" substitui o sujeito concreto de necessidades, e a pessoa da abstração legal substitui o indivíduo socialmente diferenciado, de carne e osso. Assim, estamos na presença do mesmo duplo movimento do concreto para o abstrato, a mesma dupla abstração da forma a partir do conteúdo, que caracteriza a forma-mercadoria. ${ }^{148}$

Eis finalmente o modo como as imagens do Direito Privado seduzem a todos. Não é uma característica essencial de seu conteúdo como a vagueza, a inconsistência ou a proteiformidade, de onde nasce sua capacidade de ofuscamento ideológico. É certo que só podem constituir-se num sistema ideológico porque silenciam, por estarem repletas de vazios, porque "o sujeito de 'direitos iguais' substitui o sujeito concreto de necessidades, e a pessoa da abstração legal substitui o indivíduo socialmente diferenciado, de carne e osso", ou seja, em que as narrativas traçam o desenho do indivíduo abstrato, existente apenas na própria narrativa. Mas a força desse processo de constituição do indivíduo abstrato não decorre do processo primário de abstração de suas características concretas. A fantasmagoria só se mantém em pé, reproduzindo insistentemente a miragem, porque o direito aparece como norma, isto é, assume uma forma na qual ele, que é produto, se manifesta como indepen-

Law”, op. cit., p. 575.

${ }^{147}$ Isaac D. Balbus, “Commodity Form and Legal Form: An Essay on The 'Relative Autonomy' of the Law”, op. cit., p. 575.

${ }^{148}$ Isaac D. Balbus, “Commodity Form and Legal Form: An Essay on The 'Relative Autonomy' of the 
dente da atividade de sua criação, como objeto independente, de cabeça para baixo. A criatura, a norma, faz crer a seu criador que existe e vive independentemente dele e que não é ele quem a criou ou de quem é parasita. Como o vampiro de que fala $O$ Capital: como trabalho morto, o capital, "como um vampiro, vive apenas da sucção de trabalho vivo, e vive tanto mais quanto mais trabalho vivo suga". ${ }^{149}$

\section{Direito como interpretação em construção?}

O positivismo, apesar de imortal (agora é possível perceber o porquê), tem vários opositores. Alguns pretenderam encontrar nas normas éticas um "fundamento último" para as normas jurídicas, retornando, de uma maneira mais ou menos explicitamente comprometida com uma doutrina da natureza humana, a uma teoria do direito natural. Outros tentaram, das mais variadas maneiras, retraduzir o conceito de norma num padrão de comportamento empiricamente verificável (as decisões judiciais, as condutas individuais reiteradas) e, quem sabe, até mesmo estatisticamente mensurável (a família do "realismo jurídico" e sua vizinha sociologizante). Desde os anos setenta, porém, um adversário levantou-se e roubou o ringue: o "interpretativismo" ou "interpretatismo" (como prefere ser chamado).

À primeira vista, ele — ele tem um nome: Ronald Dworkin, o autor do momento se alia à rejeição do nomocentrismo. ${ }^{150}$ Sua tese básica é a recusa a separação entre os fatos puros e as regras que se aplicariam a eles, e a correlata contrapartida da exterioridade entre a atividade interpretativa e a regra como objeto interpretado. Se o direito é uma "prática social argumentativa" que se autodefine ao mesmo tempo em que apresenta uma interpretação que justificará a decisão, a centralidade da norma deixa de fazer qualquer sentido. Como prática social argumentativa, a interpretação no direito é construtiva (a exemplo da interpretação do crítico de uma obra de arte), e não "científica" nem "conversacional". 151

Law”, op. cit., p. 577.

${ }_{149}$ Marx, O Capital, vol. I, op. cit., p. 392.

150 José Reinaldo de Lima Lopes, corajosamente, chamou a atenção para o caráter extremamente provinciano da teoria de Dworkin, que ignora um debate já consolidado na tradição romano-germânica há pelo menos duzentos anos. Mesmo a "descoberta" dos princípios e a aposta de que teriam uma estrutura lógica diversa das regras é algo no mínimo discutível. A esse respeito, veja-se "Juízo jurídico e a falsa solução dos princípios e das regras" (Revista de Informação Legislativa. Brasília, 2003, n. 160), p. 4964.

${ }^{151}$ Sobre as três espécies possíveis de interpretação, conforme Dworkin, veja-se Ronaldo Porto Macedo Junior, $O$ direito em desacordo: $O$ debate entre o interpretativismo e o convencionalismo jurídico, op. cit, p. 106. Dworkin padece de uma concepção extremamente estreita de "interpretação literária" e nunca, até onde me é possível saber, diante do enorme leque de possibilidades em que se poderia pensar ao 
Tudo se passa como se, para identificar o que seja o direito, o observador estaria obrigado a entrar dentro dele e a praticá-lo. Tal como ocorria com Hart, um observador externo digamos, um extraterrestre, um antropólogo em Marte — não seria capaz de compreender aquele jogo de tênis, enquanto jogo dotado de regras, que Wittgenstein descreve nas Investigações Filosóficas, mas apenas de descrever o comportamento mais fisicamente exterior dos participantes. Práticas sociais guiadas por regras exigiriam uma compreensão interna, o que nos conduziria à inevitável atividade de interpretação para defini-lo. Noutras palavras, definir o direito significaria apresentar uma interpretação construtiva em que se descreve seu significado numa prática que o constitui.

O que não prescindiria de apresentar uma "hipótese política" que permitisse essa interpretação-identificação do direito. Daí porque o teórico do direito não tem como afastarse de juízos avaliativos do direito. Sugado para dentro do próprio direito no exato momento em que pretendia delimitá-lo, o teórico do direito não teria como adotar uma perspectiva valorativamente neutra, pois no momento mesmo em que tiver de decidir se está diante de uma "norma" do direito, terá de empregar um critério valorativo para defini-lo. Definir o direito, compreendê-lo e praticá-lo são uma coisa só e exigem a adoção de critérios, digamos agora às claras, morais (escrevamos essa palavra bem rápido), mas "internos ao direito". ${ }^{152}$ E se para compreender o que seja o direito é preciso decidir antes o que seja - rodopio de dar vertigem que faz recair o leitor de Dworkin, a cada vez que tenta sair do direito para observá-lo de fora e assumir seu ponto de vista descritivo, novamente para seu inte-

falar-se em "interpretação construtiva" (de que a interpretação artística "é espécie”), foi além da platitude de que "A forma de interpretação que estamos estudando — a interpretação de uma prática social — é semelhante à interpretação artística no seguinte sentido: ambas pretendem interpretar algo criado pelas pessoas como uma entidade distinta delas, e não o que as pessoas dizem, como na interpretação da conversação, ou fatos não criados pelas pessoas, como no caso da interpretação científica." (Ronald Dworkin, O império do direito. São Paulo, Martins Fontes, 1999, p. 61). Para ele, interpretação é sinônimo de Wilheim Dilthey, "um filósofo alemão que foi especialmente influente em dar forma ao debate sobre a objetividade nas ciências sociais" e que "usou a palavra verstehen para descrever especificamente o tipo de entendimento que adquirimos ao saber o que outra pessoa quer dizer com aquilo que diz". E conclui, para desespero de um leitor avisado e que lhe seja simpático, numa nota de rodapé lançada para mencionar Gadamer e Habermas: "O interminável debate prossegue, dominado especialmente pelo pressuposto que descrevo no texto: de que a única alternativa ao entendimento causa-e-efeito dos fatos sociais é o entendimento conversacional com base no modelo do verstehen." (grifei) (Ronald Dworkin, $O$ império do direito, op. cit, p. 62-63). O leitor com formação filosófica, e que nem precisará dispor do paladar apurado de um gourmet, sentirá seguramente um gosto muito estranho.

${ }^{152}$ Veja-se Ronaldo Porto Macedo Junior, Do Xadrez à Cortesia: Dworkin e a Teoria do Direito Contemporânea, op. cit., p. 113. Nesse sentido, os critérios não seriam externos ao direito, como pretende o jusnaturalismo, nem uma autorização fornecida pelo direito positivo, como o positivismo inclusivista permite. Trata-se de uma moralidade (política e pública) interna ao direito e que, como já se pode ima- 
rior "avaliativo" —, então a conclusão é que o direito é necessariamente uma prática decisória guiada por princípios, em que o juiz procura (ou deve procurar: o nome de seu juizmodelo é Hércules) ajustar o fundamento de sua decisão à "tradição jurídica" (no sentido mais amplo) a que pertence.

Não há, portanto, lacunas: todo "caso difícil" (porque não previsto claramente numa "regra" - aspas necessárias, obviamente) tem uma resposta, e mais, uma única resposta, que corresponde à avaliação do caso concreto a partir de uma interpretação global do direito. É, portanto, só por uma concepção do direito, prática interpretativo-decisória, ou seja, atividade integrativa (a célebre concepção do "direito como integridade") a partir de si própria, que a decisão se tornaria possível. Dito de outra forma: sem que o juiz se represente o direito a partir de uma "moralidade interna", figure para si sua prática decisória institucional dentro do quadro mais amplo da tradição jurídico-política a que pertence, não seria possível explicar nem o que seja o direito, nem como a decisão judicial é possível. O juiz não decide aplicando regras a casos concretos. O juiz, segundo Dworkin, "interpreta": o que significa, em suma, que o direito é uma interpretação construtiva da história jurídicoinstitucional a que pertence.

Não é, obviamente, o caso de aqui prosseguir por mais páginas, seja descrevendo com maior ou menor acuidade as teses de Dworkin, seja recolhendo os termos do debate com aqueles que ocupam atualmente o centro do campo acadêmico americano na filosofia do direito (o catolicismo ultraconservador neojusnaturalista de John Finnis; as diversas personagens do atual positivismo jurídico; o clube, com ternos sempre muito elegantes, das análises econômicas do direito; ou o "refugo repugnante e repulsivo" lançado na vala comum dos Critical Legal Studies). ${ }^{153}$ Cabe notar, porém, que o interpretatismo (Dworkin prefere esse termo, "interpretatista", e faz sentido, pois quer separar-se de uma concepção tradicional interpretativista do direito), se rompe com o nomocentrismo, nem por isso quis dar os passos seguintes para compreender o que constitui essa "história jurídicoinstitucional" ou essa "moralidade do direito". A moralidade interna do direito não é sua ideologia intrínseca. Ela não é imaginada como uma representação da realidade, mas antes como uma interpretação que encerrada em si mesma. É preciso que se diga: o liberalismo de Dworkin só lhe permite compreender o direito como um processo de autocriação insti- 
tucional realizado pelas decisões judiciais que rejuvenescem continuamente uma "tradição jurídica" de afirmação de direitos. Como essa tradição jurídica é a dos direitos e garantias fundamentais assegurados pela Constituição americana, não é de se estranhar que, na lacuna, o juiz decida pela “tese dos direitos”, nem que Dworkin não se interesse por uma crítica do direito. E muito menos o veja como uma prática de poder guiada por representações ideológicas da realidade. Longe disso: o liberal progressista caminha somente até o ponto em que deseja que a tradição permaneça "sempre viva", num aggiornamento permanente do passado. O direito consistiria justamente nisso e - justamente por isso — não vai ser outra coisa senão atividade contínua de interpretação.

Dworkin teve o mérito de chamar a atenção para o fato de que o direito não é norma, mas atividade interpretativa dos juízes. Mas seus pressupostos não lhe permitiram chegar até uma crítica do direito como práxis ideológica. A "moralidade interna" constitui uma representação social a que os juízes aderem para a elaboração da decisão. Dworkin apontou para a imagem do indivíduo e seus direitos - o indivíduo, como concebido para um modelo de sociedade "aberta e livre", como Habermas ou Rawls a teriam concebido, cada um a sua maneira - que essa tradição jurídica estaria encarregada de construir. A crítica dessa imagem, porém, restou ofuscada nas polêmicas com a análise econômica do direito (pois o direito não pode definir-se por uma função que lhe seja exterior) e com os vários soldados do exército positivista. E mesmo que não tivesse sido assim, não acredito que o tivesse querido.

\section{Direito como norma, como práxis e como ideologia}

"O direito não é o que ele de fato é". Essa afirmação, que pode ser um clichê tomada fora de algum contexto, ou uma boutade lançada por algum jovem acadêmico de direito que acabou de descobrir a perda da vocação, está agora talvez em condições de ser melhor entendida nestas páginas finais. Recolhamos os resultados.

$\mathrm{O}$ direito tem um modo de aparição peculiar. Como vimos, seu modo de aparição fundamental é a norma escrita e, em segundo lugar, as interpretações doutrinárias e decisões jurisprudenciais que pretendem depender dessa primeira figura. O leigo identifica o direito com a espécie normativa da lei. Esta última aparece, ainda que com mais sofistica-

precisão boa parte desse debate. 
ção para seus especialistas, como sendo sua figuração por excelência.

Se sua aparência é essa, sua essência, porém, revela ser muito diferente. Vimos que tanto na sua produção - como práxis — quanto no seu modo de aparição — como produto dessa práxis - ele exprime conteúdos vagos que permitem que a decisão e a interpretação possam permanecer imunes e em contínua atividade. Vimos também que esses conteúdos formam imagens, novamente vagas e imprecisas, estruturadas através de narrativas do que se espera que seja o comportamento individual ou a estrutura da vida social. Tais imagens-narrativas, assim, organizam uma representação da vida social que realimentam as narrativas, as decisões e as interpretações e são por elas novamente realimentadas. Os atores sociais envolvidos nessa prática são iniciados a essa maneira de enxergar a vida social através de seu processo de formação profissional. É ali que se inicia a introdução do estudante à "comunidade interpretativa", com todas suas práticas sociais cognitivas e simbólicas. É a "comunidade interpretativa" quem produz e reproduz a representação social que guia decisões e interpretações jurídicas.

Práxis argumentativa guiada por uma ideologia, sua forma mantém uma relação de necessidade e de contraditoriedade com sua essência. "A aparência", ensinava Hegel no livro II de sua Lógica, “é, por fim, a essência mesma, mas a essência numa determinação, se bem que de maneira tal que esta é somente seu momento, e que a essência é seu próprio aparecer em si mesma". ${ }^{154}$ Sua aparição na forma de norma ou aplicação da norma é essencial para o efeito de neutralidade, isonomia e independência do direito, bem como de imparcialidade e universalidade. Seu conteúdo lacunoso, pleno de silêncios e não-ditos, cujo núcleo é a história ideológica do indivíduo abstrato da moderna sociedade burguesa, exige a forma da norma e do fetichismo de sua autonomia.

Como neste trabalho vimos pedindo emprestado a Hegel e sua família as ferramentas de sua oficina, e com bem poucos agradecimentos, seria de muito maus modos deixar de convidá-lo para o encerramento. Como sempre ocorre quando nos encontramos na presença do Geist des Widerspruchs, o ar costuma tornar-se insuportavelmente rarefeito (há quem diga senti-lo, ao contrário, muito pesado toda vez que se manifesta). ${ }^{155}$ Fica a advertência

\footnotetext{
${ }^{154}$ Hegel, Ciencia de la Lógica II (trad. de Augusta e Rodolfo Mondolfo. Buenos Aires: Hachette, 1968), p. 349.

${ }^{155}$ Sobre o "espírito de contradição organizado", um certo camponês falso ingênuo, Mefistófeles e, naturalmente, o porquê do surgimento da dialética no anômalo contexto ideológico alemão do século XIX, veja-se Paulo Arantes, "Origens do Espírito de Contradição Organizado" (In: Ressentimento da Dialética. São Paulo: Paz e Terra, 1996), p. 213-241.
} 
àqueles que a natureza não os dotou de bom fôlego:

A verdade do fenômeno consiste na relação essencial. Seu conteúdo tem uma imediata independência e, precisamente, tem a imediação existente e a refletida, ou a reflexão idêntica consigo mesma. Ao mesmo tempo, nesta independência, este conteúdo constitui um conteúdo relativo, absolutamente só como reflexão em seu outro, ou como unidade da relação com seu outro. Nesta unidade, o conteúdo independente é algo posto, superado; mas precisamente essa unidade constitui sua essencialidade e independência; esta reflexão em outro é reflexão em si mesmo. A relação tem lados, porque é reflexão em outro; assim tem a diferença de si mesma em ela, e os lados são subsistências independentes, dado que na sua indiferente diversidade mútua estão quebrados em si mesmos, de modo que o subsistir de cada um tem igualmente seu significado só na relação com o outro, ou na unidade negativa de ambos. [...]

O que algo é, o é, portanto, totalmente em sua exterioridade; sua exterioridade é sua totalidade, e é também sua unidade refletida sobre si. Sua aparência não é só a reflexão em outro, mas sim sobre si, e, por conseguinte, sua exterioridade é a exteriorização do que é em si. E dado que, desse modo, seu conteúdo e sua forma são absolutamente idênticos, ele não consiste, em si e para si, em nada mais do que isso, num exteriorizar-se. Consiste em revelar sua essência, de maneira que esta essência consiste precisamente só em ser o que se revela. ${ }^{156}$

${ }^{156}$ Hegel, Ciencia de la Lógica II, op. cit., p. 451 e 465. Os grifos, é claro, são meus. 


\section{BibLiOgRAFIA}

ADLER, Matthew D. (2010). "Regulatory Theory". In: Dennis Patterson (org.), A Companion to Philosophy of Law and Legal Theory. 2. ${ }^{\text {a }}$ Ed. Oxford: Blackwell Publishing. ADORNO, Theodor e HORKHEIMER, Max (1973). "Ideologia". In: Temas básicos da sociologia. São Paulo, ed. Cultrix.

AMARAL JÚNIOR, Alberto (2012). Curso de Direito Internacional Público. São Paulo: Atlas, 3. ${ }^{\mathrm{a}} \mathrm{Ed}$.

ARANTES, Paulo (1996). “Origens do Espírito de Contradição Organizado”. In: Ressentimento da Dialética. São Paulo: Paz e Terra.

ARISTÓTELES (1991). Ética a Nicômaco. In: Os Pensadores - Aristóteles. Tradução de Leonel Vallandro e Gerd Bornheim, da versão inglesa de W. D. Ross. 4. ed., São Paulo: Nova Cultural.

AZARIAN, Reza (2008). “Outline of an Economic Sociology of Islamic Banking”. International Journal of Business and Social Science, 17.

BALBUS, Isaac D. (1977). "Commodity Form and Legal Form: An Essay on The 'Relative Autonomy' of the Law". Law and Society Review, 11.

BAUCH, Bruno (1904). Luther und Kant. Berlin: Reuther \& Reichard.

BENTHAM, Jeremy (1974). Uma introdução aos princípios da moral e da legislação. Trad. de Luis João Baraúna. In: Os Pensadores: Bentham e John Stuart Mill. São Paulo: Abril Cultural.

CAENEGEM, Raoul Van (2000). Uma Introdução Histórica ao Direito Privado. São Paulo: Martins Fontes.

CHAGAS, Carlos Orlandi (2014). Novos defeitos do negócio jurídico. São Paulo: Faculdade de Direito, Universidade de São Paulo. Tese de Doutorado em Direito Civil. 
CHAUÍ, Marilena (2003). O que é ideologia? São Paulo: Brasiliense.

COASE, Ronald (1937). "The Nature of the Firm”. Economica (Blackwell Publishing) 4.

COELHO, Roseli Martins (2001). Social-democracia: formas e reformas. São Paulo: Humanitas.

COLLINS, Hugh (1982). Marxism and Law. Oxford: Oxford University Press.

COMPARATO, Fábio Konder (2008). O Poder de controle na sociedade anônima. Rio de Janeiro: Editora Forense.

COSTA, Judith Martins (2005) "Reflexões sobre o Princípio da Função Social dos Contratos". Revista Direito GV, n. 1.

CUESTA ABAD, José Manuel (org.). Teorias literarias del siglo XX. Madrid: Akal, 2005.

DE AQUINO Tomás (1990). Suma de Teologia, III. Madrid: Biblioteca de Autores Cristianos.

DE FARIAS, Cristiano Chaves e ROSENVALD, Nelson (2011) Curso de Direito Civil Teoria Geral. Rio de Janeiro: Lúmen Júris, 9. ${ }^{a}$ Ed..

DE OLIVEIRA, Francisco, BRAGA, Ruy e RIZEK, Cibele Saliba (orgs.) (2010). Hegemonia às avessas: Economia, política e cultura na era da servidão financeira. (São Paulo: Boitempo.

DE SAINTE CROIX, Geoffrey (1981). The Class Struggle in the Ancient Greek World. Ithaca: Cornell University Press.

DE SOTO, Jesús Huerta (2002). "La teoría bancaria en la Escuela de Salamanca". La Ilustración Liberal, 11.

DELEUZE, Gilles (1981). Francis Bacon, logique de la sensation. Paris: La Différence.

DWORKIN, Ronald (1980). “Is Wealth a Value?”, The Journal of Legal Studies 9 (p. 191226).

DWORKIN, Ronald (1999). O império do direito. São Paulo: Martins Fontes.

DWORKIN, Ronald (2002). Levando os direitos a sério. São Paulo: Martins Fontes.

EAGLETON, Terry (1976). Criticism and Ideology: a Study in Marxist Literary Theory. Londres: Verso.

EAGLETON, Terry (2005). A idéia de cultura. São Paulo: UNESP.

EAGLETON, Terry (2011). Marxismo e Crítica Literária. São Paulo: UNESP.

EWALD, François (1986). L'état providence. Paris, Grasset.

FABIANI, Jean Louis (1988). Les philosophes de la Republique. Paris, Editions de Minuit. FERRAZ JÚNIOR, Tércio Sampaio (1976). Conceito de Sistema no Direito. São Paulo: 
Revista dos Tribunais.

FERRAZ JÚNIOR, Tércio Sampaio (1998). Função Social da Dogmática Jurídica. São Paulo: Max Limonad.

FERRAZ JÚNIOR, Tércio Sampaio (2003). Introdução ao Estudo do Direito: Técnica, Decisão, Dominação. 4. Edição. São Paulo: Atlas.

FERRAZ JÚNIOR, Tércio Sampaio (2009). “A hipótese do legislador racional e a noção de justiça". Cadernos Direito GV, São Paulo, n. 6.

FERRAZ JÚNIOR, Tércio Sampaio, Direito, Retórica e Comunicação. São Paulo, Saraiva, 1997

FINNIS, John (2002). Natural Law and Natural Rights. Oxford: Oxford University Press.

FISH, Stanley (1989). Doing What Comes Naturally: Change, Rhetoric, and the Practice of Theory in Literary and Legal Studies. Durham: Duke University Press.

FISH, Stanley (2002). Is there a text in this class? Harvard: Harvard University Press.

FOUCAULT, Michel (1979). Microfísica do poder. Rio de Janeiro: Graal.

FOUCAULT, Michel (1988). História da Sexualidade I: a vontade de saber. Rio de Janeiro: Edições Graal.

FOUCAULT, Michel (1996). A Verdade e as formas jurídicas. Rio de Janeiro: Nau.

FREUD, Sigmund (2010). Novas Conferências Introdutórias à Psicanálise. Trad. de Paulo Cesar Souza. In: Sigmund Freud, Obras Completas, vol. 18. São Paulo: Companhia das Letras.

GOLDMANN, Lucien (1952). Sciences humaines et philosophie. Suivi de structuralisme génétique et création littéraire. Paris: Presses Universitaires de France, 1952.

GOLDMANN, Lucien (1955). Le dieu caché : étude sur la vision tragique dans les Pensées de Pascal et dans le théâtre de Racine. Paris, Gallimard.

GOLDMANN, Lucien (1959). Recherches dialectiques. Paris, Gallimard.

GOLDMANN, Lucien (1970). Marxisme et sciences humaines. Paris, Gallimard.

GORDLEY, James (1991). The Philosophical Foundations of Modern Contract Doctrine.

Clarendon Press: Oxford.

GORDLEY, James (2002). “The Moral Foundations of Private Law”. American Journal of Jurisprudence, 47.

GORDLEY, James (2006). Foundations of Private Law: Property, Tort, Contract, Unjust Enrichment. Oxford: Oxford University Press.

GORDLEY, James (2007). "Morality and Contract: The Question of Paternalism”. William 
\& Mary Law Review, 48.

GRINOVER, Ada Pellegrini et alli (1998). Código brasileiro de defesa do consumidor: comentado pelos autores do anteprojeto. 5. Ed. Rio dc Janeiro: Forense Universitária.

HEGEL, Friedrich W. J. (1968). Ciencia de la Lógica. Trad. de Augusta e Rodolfo Mondolfo. Buenos Aires: Hachette.

KANT, Immanuel (2002). "Sobre um pretenso direito de mentir por amor aos homens". In: PUENTE, Fernando Rey (org.). Os filósofos e a mentira. Belo Horizonte, Editora UFMG; Departamento de Filosofia - FAFICH/UFMG.

KANT, Immanuel (2011). Fundamentação da Metafísica dos Costumes. Trad. Paulo Quintela. Lisboa: Edições 70.

KANT, Immanuel (2013). Metafisica dos costumes. Tradução de Clélia Aparecida Martins. Petrópolis, Vozes.

KANT, Immanuel. Crítica da Razão Pura. Trad. de Manuela Pinto Dos Santos e Alexandre Fradique Morujão. 5. ${ }^{a}$ Ed. Lisboa: Fundação Caloustra Gulbenkian, 2001.

KENNEDY, Duncan (2004). "Legal Education and the Reproduction of Hierarchy". In: Legal Education and the Reproduction of Hierarchy: a polemic against the system: a critical edition. Nova York: New York University Press.

KRONMAN, Anthony Townsend (1980). "Contract Law and Distributive Justice". Yale Law Journal.

LOPES, José Reinaldo de Lima (2003). “Juízo jurídico e a falsa solução dos princípios e das regras". Brasília: Revista de Informação Legislativa, n. 160.

LUHMANN, Niklas (1989). Ecological Communication. Chicago: The University of Chicago Press.

LUKÁCS, George (1959). El Asalto a la Razón. Trad. de Wenceslao Roces. México: Fondo de Cultura Económica.

LUKÁCS, George (1969). Historia y Consciencia de Clase, México, Grijalbo.

MACEDO JUNIOR, Ronaldo Porto (2011). Carl Schmitt e a fundamentação do direito. 2. ed. São Paulo: Saraiva.

MACEDO JUNIOR, Ronaldo Porto (2012). Do Xadrez à Cortesia: Dworkin e a Teoria do Direito Contemporânea. Tese de Livre-Docência. Departamento de Filosofia e Teoria Geral do Direito. Faculdade de Direito de São Paulo da USP.

MACEDO JUNIOR, Ronaldo Porto (2014). O direito em desacordo: O debate entre o interpretativismo e o convencionalismo jurídico. Tese de titularidade. Faculdade de Direito 
de São Paulo da USP.

MACHEREY, Pierre (1971). Pour une théorie de la production littéraire, Paris, François Maspero.

MALFATTI, Alexandre David (2003). O direito de informação no Código de Proteção e Defesa do Consumidor. São Paulo, Alfabeto Jurídico.

MARQUES, Cláudia Lima (1998). Contratos no Código de Proteção e Defesa do Consumidor. o novo regime das relações contratuais. 3. Ed. São Paulo: Editora Revista dos Tribunais.

MARX, Karl (2011). Grundrisse: manuscritos econômicos de 1857-1858: esboços da crítica da economia política. Trad. de Mario Duayer, Nélio Schneider. São Paulo: Boitempo; Rio de Janeiro: Ed. UFRJ.

MARX, Karl (2013). O Capital - Crítica da economia política. Livro I: O processo de produção do capital. Trad. Rubens Enderle. São Paulo.

MÉSZÁROS, István (2008). Filosofia. ideologia e ciência social São Paulo: Boitempo.

MILL, John Stuart (1996). Princípios de Economia Política. Trad. de Luiz João Baraúna. In: Os Economistas - John Stuart Mill. São Paulo: Nova Cultural.

MILL, John Stuart (2005). O Utilitarismo. Trad. e introd. de Pedro Galvão. Porto: Porto Editora.

MONTEIRO, Washington de Barros (1966). Curso de Direito Civil - Parte Geral. $5^{\mathrm{a}}$ edição. São Paulo: Saraiva.

MUÑOZ, Alberto Alonso (2001). Liberdade e Causalidade: Ação, Responsabilidade e Metafisica em Aristóteles. São Paulo: Discurso Editorial.

MUÑOZ, Alberto Alonso (2008). Transformações da Teoria Geral do Direito: Argumentação e Interpretação do Jusnaturalismo ao Pós-Positivismo. São Paulo: Quartier Latin.

NASCIMENTO, Amauri Mascaro (2011). Curso de direito do trabalho: história e teoria geral do direito do trabalho: relações individuais e coletivas do trabalho. 26. ed. São Paulo: Saraiva.

NINO, Carlos Santiago (1989). Consideraciones sobre la Dogmática Jurídica. Cidade do México: Universidad Nacional Autônoma de México.

NUNES, Luis Antonio Rizzatto (2012). Curso de direito do consumidor. 7. ed. São Paulo: Saraiva.

PASCHUKANIS, Jewgeni (1976). La Teoría General del Derecho y el Marxismo. Trad. de Carlos Castro. Ciudad de México: Editorial Grijalbo. 
PATTERSON, Dennis (org.) (2010). A Companion to Philosophy of Law and Legal Theory. 2. ${ }^{a}$ Ed. Oxford: Blackwell Publishing.

PEREIRA, Caio Mário da Silva (2013). Instituições de Direito Civil, vol. I, Rio de Janeiro: Forense.

PERELMAN, Chaïm. Lógica jurídica: nova retórica. São Paulo: Martins Fontes, 2000.

PINTO, Louis (2007). La vocation et le métier de philosophe. Pour une sociologie de la philosophie dans la France contemporaine. Paris: Seuil.

POSNER, Richard (1979). "Utilitarianism, Economics, and Legal Theory”, The Journal of Legal Studies, 8.

POSNER, Richard (1992). Economic Analysis of Law. Boston: Little, Braum \& Company. POSNER, Richard (2008). How Judges Think. Harvard: Harvard Unversity Press.

PRADO JÚNIOR, Bento (1983). "Não dizer a verdade equivale a mentir?”. Discurso, n. 15 .

RAZ, Joseph (1999). Practical Reason and Norms. 2. ${ }^{a}$ Ed. Oxford: Oxford University Press.

REALE, Miguel (1999). O Projeto do Novo Código Civil. 2a ed. São Paulo: Saraiva.

REALE, Miguel (2003). "Um artigo-chave do Código Civil”. In: O Estado de S. Paulo. 21/06/03.

REMISE, Jac (1978). Diableries: La Vie Quotidienne Chez Satan a la Fin du 19e Siecle. Paris, Balland.

RODRIGUES, Silvio (2014). Direito Civil - Parte Geral. Vol. I, 34. ${ }^{a}$ Ed. São Paulo: Saraiva.

RODRIGUEZ, José Rodrigo, COSTA, Carlos Eduardo Batalha da Silva e BARBOSA, Samuel Rodrigues (2010). (Org.). Nas fronteiras do formalismo. SãoPaulo: Saraiva.

SEN, Amartya (2009). A Idéia de Justiça. Trad. de Denise Bottmann e Ricardo Doninelli Mendes. São Paulo: Companhia das Letras.

SENNET, Richard (2005), A Corrosão do Caráter: conseqüências pessoais do trabalho no novo capitalismo. São Paulo: Record.

SIQUEIRA, José Antonio (2002). Kelsen e o monumento da razão pura: uma análise do conceito de validade jurídica. Dissertação de Mestrado. Departamento de Filosofia e Teoria Geral do Direito. Faculdade de Direito de São Paulo da USP. São Paulo.

TEPEDINO, Gustavo (2004). "Premissas Metodológicas para a Constitucionalização do Direito Civil”. In: Temas de Direito Civil. $3^{\mathrm{a}}$ edição. Rio de Janeiro: Renovar. 
TEPEDINO, Gustavo (2007) "Normas Constitucionais e Direito Civil na Construção Unitária do Ordenamento". In: Daniel Sarmento e Cláudio Pereira de Souza Neto (orgs.). $A$ Constitucionalização do Direito: Fundamentos Teóricos e Aplicações Específicas. Rio de Janeiro: Lumen Júris.

TORRES FILHO, Rubens Rodrigues (2002), “A virtus dormitiva de Kant”. In: Ensaios de Filosofia Ilustrada. São Paulo: Iluminuras.

VAN HOOFT, Stan (2013). Ética da Virtude. Petrópolis: Vozes.

WARAT, Luís Alberto (2004). "Los pressupuestos kantianos y neokantinos de la teoria pura del derecho". In: Epistemologia e ensino do direito: o sonho acabou. Florianópolis: Fundação Boiteux.

WARAT, Luís Alberto (2004). “Sobre la dogmática jurídica”. In: Epistemologia e ensino do direito: o sonho acabou. Florianópolis: Fundação Boiteux.

WEBER, Max (1994). A Ética Protestante e o Espírito do Capitalismo. São Paulo: Pioneira.

WEINRIB, Ernst (2012). The Idea of Private Law. Oxford: Oxford University Press.

WIEACKER, Franz (1967). História do Direito Privado Moderno. Lisboa: Fundação Caloustre Gulbenkian.

WILLIAMSON, Oliver E. (1981). "The Economics of Organization: The Transaction Cost Approach". The American Journal of Sociology 87.

WILLIAMSON, Oliver E. (1998). The Economic Institutions of Capitalism: Firms, Markets, Relational Contracting. Michigan: Free Press.

WILLIAMSON, Oliver E. (2002). "The Theory of the Firm as Governance Structure: From Choice to Contract". Journal of Economic Perspectives. 